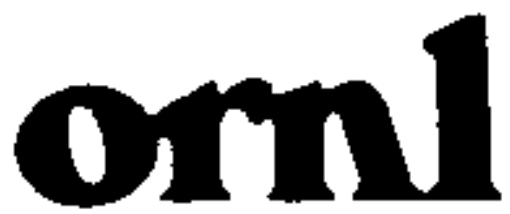

OAK RIDGE NATIONAL LABORATORY

\title{
THE SCOPE OF THE WEATHERIZATION ASSISTANCE PROGRAM: \\ PROFILE OF THE POPULATION IN NEED
}

MARTrW MARUETTA

Joel F. Eisenberg RECEIVED Eugene Michels David Carroll Nancy Berdux JUL 039996

OSTI

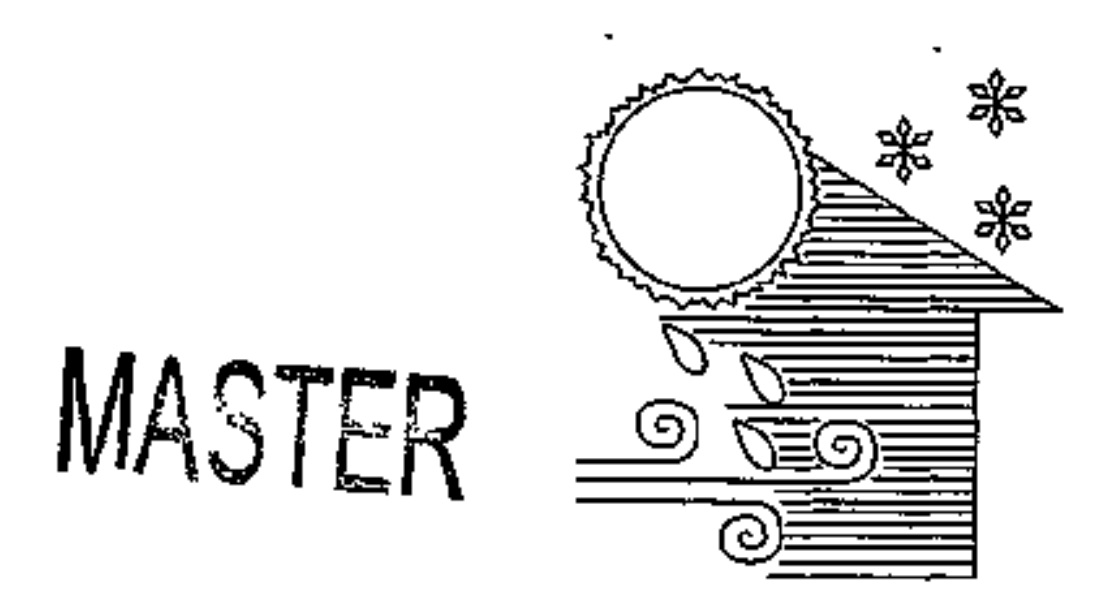


This report has been reproduced difectly fion the besi availabls copy.

Avellable to DOE and DOE contractors from the Ditice of Scienlitic and Technicat hiformation, F.O. Box 62, Osk fidpe. TN 37a31: prices available trom (615) 576.B401، FTS 62C-8401.

Avelbele to the pubte trom the Neliontel Technical misormation Service. U.S. Gepertment of Comuneres, 5295 fort Royal Rd., Springtield, VA 22161.

Thls seport wes greparad as an account ol wark spontored by an egency of the Uniked States Goveminent. Neither the Uniked Slates Governinenl nor any apency themof, mor any ol their employeas, makes any wastanty, express of implied, or asatumes any legal liablliy or responsibity for the acceuracy, completeness, or usefukess of eny intormetion. appareltus, product, of process dis. closed, or repressenils that iss use would nol intringe privately owned fights. Reference thereis to eny specilic comunercial producl, process. or serwio by Irade name. tradermerk, manutacturer, or alkenwise, does not necessarily consit. tute or imply ine endorsement, recommendetion. of tevoring by the Uniled States Government or any epency thereot. The viows and opinions of autherg

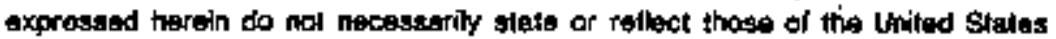
covernmenl or eny agentey thereot.

\section{TABLE OF CONTENTS}


3.6.4 Ethricity

3.7 PROGRAM PARTICIPATION AMONG HIGH-EXPENDITURE HOUSEHOLDS

4. HIGH-BURDEN AND HIGH-BURDEN/ HIGH-EXPENDITURE HOUSEHOLDS

4.1 HIGH-BURDEN HOUSEHOLDS: HOUSING CHARACTERISTICS

4.1.l Tenure of High-Burden Households

4.1.2 High-Burden Households: Heating Fuel.

4.2 ENERGY EXPENDTTURES OF HIGH-BURDEN HOUSEHOLDS

4.3 INCOME OF HIGH $+B U R D E N$ HOUSEHOLDS.

4.4 ENERGY BURDEN OF HHGH-BURDEN HOUSEHOLDS

4.5 DEMOGRAPHICS OF THE HIGH-BURDEN POPULATION.

4.6 PROGRAM PARTICIPATION AMONG HIGH-BURDEN HOUSEHOLDS ...............4.5

4.7 HIGH-BURDEN/HIGH-EXPENDITURE HOUSEHOLDS ...................................4.5

4.7.1 Housing Characteristics of High-Burden/High-Expenditure Households .....4.6

4.7.2 Tenure of the High-Burden/High-Expenditure Households...........................4.6

4.7.3 Heating Fuels of the High-Burden/High-Expenditure Households.................4.6

4.7.4 Energy Expenditures and Income of the High-Burden/

High-Expenditure Households.

4.7.5 Energy Burden: High-Burden/High-Expendioure Households.......................4.7.

4.7.6 Demographics and Program Participation of High-Expendituref

High-Burden Househoids

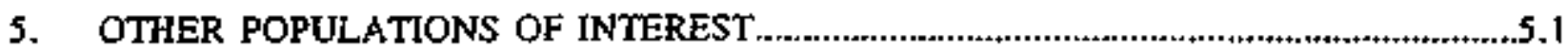

S.I LOW-EFFICIENCY HOUSEHOLDS....................................+..................................

5.I.I Low-Efficiency Households: Tenure, and Fuel Use...................................... ]

5.1 .2 Low-Efficiency Househoids: Energy Expenditures and Burden $\ldots . . . . . . . . . . . . . . .5 .2$

5.2 THE PERSISTENT.ELIGIBLE HOUSEHOLDS.................................................. 5.2

5.3 THE WEATHERIZED POPULATION IN 1990

6. COMPARISON OF ELIGIBLE, HIGH-BURDEN AND

HIGH-EXPENDITURE POPULATIONS AND CONCLUSIONS .......................................6.t

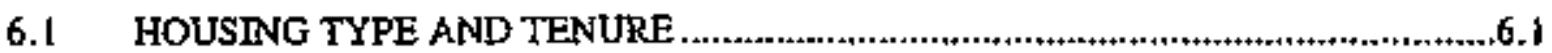

6.2 DEMOGRAPHICS AND PROGRAM PARTICIPATION

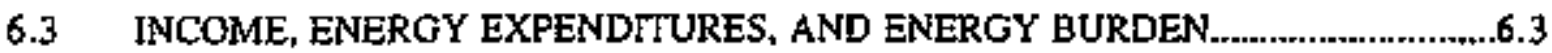

6.4 STATISTICAL SUMMARY AND CONCLUSIONS............................................6.5

Appendix A.

Appendix $\mathrm{B}$

Appendix C 


\section{LIST OF FIGURES AND TABLES}

Fignre 2.1 Main heating Fuel by Region

Figure 2.2 Energy Bufden for Eligible Households by Region ................................................2.9

Figure 3.1 Housing Type and Tenure for High-Expenditure Households .................................+3.3

Figure 4.I Housing Type and Tenure for High-Burden Households.........................................4.2

Figure 6.1 Low-Income Housing Types by Subgroups ..........................................................6.2

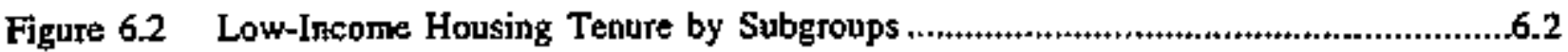

Figure 6.3 Residential Energy Expenditures by Subgroups..................................................6.4

Figure 6.4 Residential Energy Burden by Subgruups.................................................................6.5

Table 2.1 Housing Types for Low-Income Households

Thousands of Households in 1990.............................................................................

Table 2.2 Housing Types for Low-Income Households Percent of Households in 1990

Table 2.3 Average Resjidential Energy Expenditures Low-Income Hovsefoids in 1990.

Table 2.4 Incone, Energy Expenditures and Energy Burden of Eligible Low-Income Households in 1990

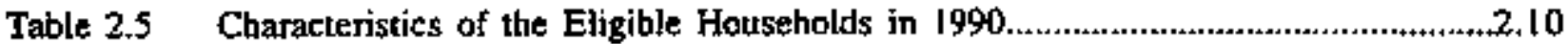

Table 3.1 Income, Energy Expenditures and Energy Burden on High-Expenditure Households in 1990 .

Tabie 4,1 Income, Energy Expenditures and Energy Burder of High+Burden Househoids in 1990

Tabie 4.2 Incone, Energy Expenditures and Energy Burden High-Burden/High-Expenditure Households in 1990

Table 6.1 Demographics and Program Participation Peccent in 1990 . 


\section{ACKNOWLEDGEMENTS}

Many people have participated in the design and implementation of this study. Of particular note are the members of the Evaluation's Working Group who have provided extensive input to this process. The authors are gratefut for their advice, comments, and suggestions, without which this report would rot have been possible. These individuals and their affiliations ate listed below.

\begin{tabular}{|c|c|c|}
\hline $\begin{array}{l}\text { Jeff Ackermana } \\
\text { Colorado Deparment of Local } \\
\text { Affairs }\end{array}$ & $\begin{array}{l}\text { Sharon Gill } \\
\text { U.S. Department of Energy. }\end{array}$ & $\begin{array}{l}\text { Phit Miklmester } \\
\text { Aspen Systens Corporalion }\end{array}$ \\
\hline $\begin{array}{l}\text { Don Bartett } \\
\text { Misscuri Department of Natural }\end{array}$ & $\begin{array}{l}\text { Laryy Goldberg } \\
\text { Sequoja Technical Services }\end{array}$ & $\begin{array}{l}\text { John Mitchell } \\
\text { Consolidated Edison Company, } \\
\text { Inc. }\end{array}$ \\
\hline Mary Ann Bernald & $\begin{array}{l}\text { Miriam Goldberg } \\
\text { XENERGY }\end{array}$ & $\begin{array}{l}\text { Bary Moline } \\
\text { American Public Power Assoc. }\end{array}$ \\
\hline Edison Electric instinte & Indy Gregory & John Neison \\
\hline $\begin{array}{l}\text { Jeff Brown } \\
\text { North Carolina Departmenl of }\end{array}$ & $\begin{array}{l}\text { Center for Neighbortiood } \\
\text { Developrienl }\end{array}$ & Wisconsin Gas Company \\
\hline Commerte & Al Guyant & Direcior, CAP Services \\
\hline $\begin{array}{l}\text { Date Canning } \\
\text { Sall t,ake Community Action } \\
\text { Agency }\end{array}$ & $\begin{array}{l}\text { Public Services Commission of } \\
\text { Wisconsin } \\
\text { Martha Hewetl }\end{array}$ & $\begin{array}{l}\text { Meg Powrer } \\
\text { National Comprnunity Action } \\
\text { Foundation }\end{array}$ \\
\hline $\begin{array}{l}\text { David Carroll } \\
\text { Response Analysis Corporation }\end{array}$ & $\begin{array}{l}\text { Center for Energy and the Urban } \\
\text { Envisonment }\end{array}$ & $\begin{array}{l}\text { Bill Prindle } \\
\text { Altiance to Save Energy }\end{array}$ \\
\hline $\begin{array}{l}\text { Mert Datin } \\
\text { Stace of Arizona } \\
\text { Departiment of Conumetce }\end{array}$ & $\begin{array}{l}\text { Bion Hownard } \\
\text { Alltance to Save Energy } \\
\text { Larry Kinney }\end{array}$ & $\begin{array}{l}\text { Ken Rauseo } \\
\text { The Commonwealth of } \\
\text { Massachusetls }\end{array}$ \\
\hline $\begin{array}{l}\text { Margaret Fejs } \\
\text { Princeton University }\end{array}$ & Syneriech Sysiems Corporation & $\begin{array}{l}\text { Jeffrey Schiegel } \\
\text { Wisconsin Energy Conservation }\end{array}$ \\
\hline $\begin{array}{l}\text { Michacl Foley } \\
\text {. }\end{array}$ & Orange and Rockland Utitities & Corporation \\
\hline Utîlity Commissioners & $\begin{array}{l}\text { Leon Litow } \\
\text { U.S. Deparinent of Heaith and }\end{array}$ & $\begin{array}{l}\text { Wendel Thompson } \\
\text { Entergy Information Administration }\end{array}$ \\
\hline $\begin{array}{l}\text { Michathl Ganley } \\
\text { Narional Rutal Electric } \\
\text { Cooperative Association }\end{array}$ & $\begin{array}{l}\text { Human Services } \\
\text { Ron Marabate }\end{array}$ & $\begin{array}{l}\text { Ken Tohinaka } \\
\text { Vemont Energy Investment Corp. }\end{array}$ \\
\hline $\begin{array}{l}\text { Richard Gerardi } \\
\text { New York Stale Depl. of State }\end{array}$ & $\begin{array}{l}\text { Jane Marden } \\
\text { American Gas Association }\end{array}$ & $\begin{array}{l}\text { Marjotie J. Witherspoon } \\
\text { National Association of Slate } \\
\text { Corntusity Setrices Prograrns }\end{array}$ \\
\hline
\end{tabular}

In addition to the above individuals, this report was prodaced under the supervision and guidance of Linda Berry and Marilyn Brown of Oak Ridge National Laboratory and Jeanne Van Vlandren of the Department of Energy. To all those who assisted us go many thanks and no responsibility for any ecrors of fact or conclusion. These belong to the authors alone. 


\section{EXECUTIVE SUMMARY}

\section{OVERVIEW}

The U.S. Department of Energy (DOE) is conducting a national evaluation of its Weatherization Assistance Program, an energy efficiency program that provides financial assistance to qualifying low-income households for the "weatherization" of their fousing units. The evaluation, being conducted for the Department by Oak Ridge National Laboratory (ORNL), is comprised of five studies. One of the five is a two-part analysis of the scope of the Weatherization Assistance Program and other resources devoted to low-income energy efficjency, including the number of dwellings weatherized to date and the population remaining to be served. This study is mefered to here as the "Scope" study.

This report presents the results of the second part of the "Scope" study, which investigates the characteristics of the poputation eligible for and in need of the DOE Weatherization Assistance Program -- The Profile of the Population in Need. The "Profile" study is an attempt to use the Energy Information Administration's Residential Energy Consumption Survey (RECS) for 1990 to define the weatherization-related characteristics of the low-income population. The RECS, a national survey with a sample size of 5,095 households, is the most reliable source for information regarding residential energy-use and housing characteristics because data is collected from fuel vendors on actual housetiold energy bills and consumption for a targe and representative sample of households.

\section{Research Objectives}

The research objective of The Eonlle of the Population in Nesed is to describe the population of tow-income households, their location, housing. energy-use and demographic characteristics in I990. The study's intent is to highlight those attributes that shed some light on the need for lowincome energy efficiency services among thase hotseholds that may qualify onder national income standards for the Weatherization Assistance Program and the Department of Health and Human Services' Low Income Home Energy Assistance Program (LIHEAP).I The study further seeks to examine the characteristics of several subsets of the low-income population for purposes of refining the understanding of how best to target and allocate ijmited weatherization resources. Among the subsets of the eligible population examined in the study and bightighted in this report ate the following:

1 The income standard for LIHEAP is the grealer of 60 percent of state median income or 150 ptrent of the poverty level. The ineome standard for the Weatherization Assistance Program is at or below 125 percent of the poveny level; however, a state may elect to use the 1.IHEAP income standard if is scale LIHEAP incone standard is at least 125 percent of the poverty level. For this study, the fiscal year 1990 state mediar income estimales and the calendar year 1989 poverty income guidelines were used with the 1990 RECS population and income dala in classifying low incone househoids. 
1) "High-Expendittre" Households -- those with high space heating costs per heating degree day and square feet of living space relative to others in their climate zone and region;

2) "High+Burden" Households -- those with high total residential energy expenditures in proportion to income relative to others in their climate zone and region;

3) "High-Eurden/High-Expenditure" Households -- those households that qualifjed in both calegories described above.

High-expenditure households are of particular interest because their high consumption, weighted by price, mey indicate that they have above-average energy savings potential. This potential is based on the fact that dweilings that consume more energy before weatherization save more energy after weatherization, a major finding of the National Weatherization Evaltation's single-farnily study.

it is a major purpose of the Weatherization Assistance Program, not only to increase energy efficiency, but also to reduce the burden of energy costs to those who can least afford it. It is therefore important to understand the celationship between bigh energy expenditures and income. One key question that this study tries to answer is the following: Is the high-expenditure set of households, which appears to have greater-than-average energy-efficjency potential, also likely to be in greater need of weatherization because high energy costs place a heavier-than-average burden on household budgets?

High-burden flouseholds are a subpopulation deserving particular attention because they can least afford the residential energy that they consume. While this may sometimes result from higherthan-ayerage energy expenditures, it may also be produced by lower-than-average income or some combination of the two. These households stand to gain the greatest benefit from the expenditure reductions that weatberizacion can produce. A key question about this population that the study tries to answer is the following: Is this set of housetolds likely to offer high energy-efficiency potential as well as being logical targets for weatherization on equity grounds?

The high-burden/high-expenditure subset is examined because, as the intersection of the high-burden and high-expenditure groups, it should highlight a population that offers both high energy-efftciency potential as well as an excellent opportunity to assist those households that are most in reed of assistance.

\section{RESIDENTIAL ENERGY-USE CHARACTERISTICS OF THE LOW-INCOME POPULATION}

This report relies on RECS as it is the only national hossehold survey that provides data an both income and energy expenditures. Based on the 1990 RECS, there were 27.9 million households with incomes at or below the higher of 60 percent of state median income or 150 percent of poverty, comprising approximately 30 percent of all U.S. households. However, not all of the 27.9 million 
househoids would have income eligible for the Low Income Home Energy Assistance Program and DOENWeatherization Assistance Program in 1990 due to limitations in RECS income data. Based on more accurate income data cotlected by the Bureau of the Census' March 1991 Current Population Survey, there were 25.9 mitlion households that were income cligible for both programs. The reader should therefore bear in mind that the statistics for "eligible" housefolds as defined by the RECS data may jnetude some households with actual incomes that were stightly above the income eligibility guidelines.

RECS is the only national data source that allows for consistent identification and cornparison among the subpopulations of interest as defined in this study. Of the 27.9 million low-intome households, 7.2 million were high burden households and 5.0 mitlion were high expenditure households. The intersecting group of high-burden/high-expenditure househoids comprised 2.1 million housefolds. These subpopulations are shown in Figure E.1. Given the RECS overcount, these subpopulations atso may be overcounied.

The population described in this report as etigible for weacherization in 1990 contained some households that had already received weatherization services from DOE or other sources, though this group is small relative to the eligible and potentially eligible pool of households. In light of the absence of data in RECS that permits identification of all the weatherized households within the low-

\section{LOW-INCOME HOUSEHOLDS AND SUBPOPULATIONS IN 1990}

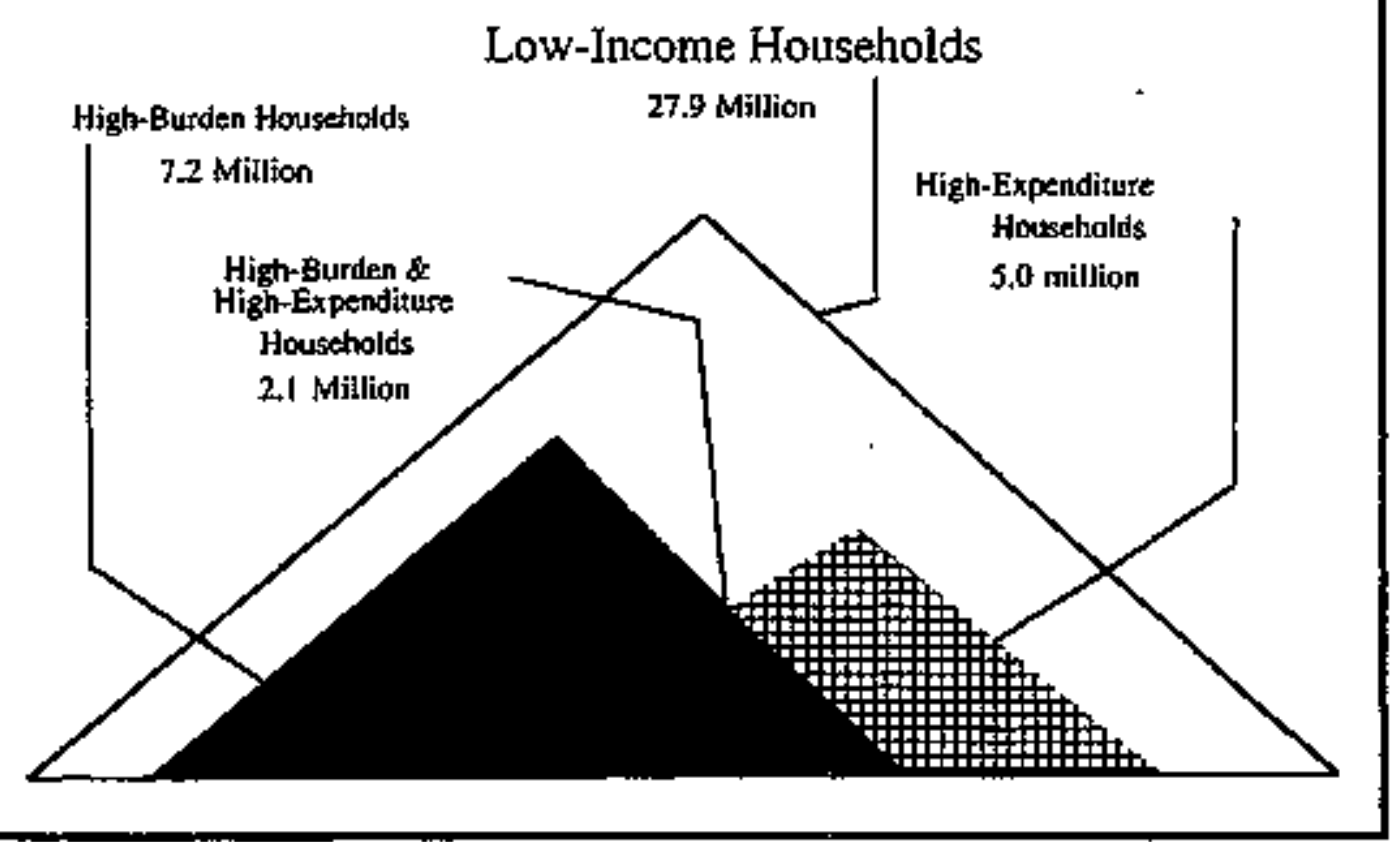

Figure E.1 Low-Income Households and Subpopulations in 1990 (Source: 1990 Residential Energy Consumption Strvey) 
income popalation, as well as the small proportion of such households in the population, this study focuses on the total eligible poptuation in 1990 as the population in need, with the understanding that some of these households have alceady been weatherized.

\section{Housing Characteristics}

Low-income households, like the population at large, tend to reside in single-fantily homes. In fact, 58.7\% lived in single-family units and an additional $8.2 \%$ lived in mobile homes. Of the remaining households, $19.1 \%$ lived in large muttifamily dwellings and $14.1 \%$ occupied apartments in small multifamily buildings of two-through-four units. Fifty percent, of low-income hoaseholds owted their own homes in 1990 . Atrong these, the vast majority, $82.6 \%$, lived in single-family units but a large number, 1.6 million or $11.4 \%$, were in mobile homes. There were 13.9 million lowincome renter householis.

Of the four Census Regions, the South had the targest number of the poor, 37\% of all eligible households. Approximately $23 \%$ lived in the Midwest. The West and Northeast each contained $20 \%$ of all low-income househoids.

\section{Heating Fuel}

The pattern of primary fuel use among the poor is generally the same as that for the population at large. Fifty-three percent of low-jncome householós heated with natural gas in 1990 as compared to $55 \%$ of alt U.S. houseftolds. Twenty percent of low-income househoids heated with electricity, and home heating oil was used by $11 \%$. Those proportions are comparable to the respective percentages of $22.9 \%$ for electricity and $11.7 \%$ for fuel oil among ail householids. The percentage of households heating with propane was $7.6 \%$ for low-income households compared to $4.7 \%$ for all U.S. households.

\section{Residential Energy Expenditures}

In 1990 the average Jow-income household $\$ p e n t \$ 994$ for residential energy, with substantial tarjation by fuel type, housing type, and region. This compares to an average residential energy expenditure of $\$ 1,172$ for all U.S. househoids. The average expenditure for alt low-income households in the Northeast was $\$ 1,201$, nearly $60 \%$ higher than the average of $\$ 756$ in the West. Expenditures in the Midwest and South were closer to the over-al] low-income average at $\$ 1,094$ and $\$ 958$ respectively.

Househoids hearing with electricity, located more frequently in warmer regitons, tended to bave much lower average residential energy expenditures than the low-income population as a whole at \$826. Those heating with fuel oil, on the other hand, has the highest expenditures, at an average of $\$ 1,246$, because more of them were located in the colder parts of the country where heating loads 
$\exists=$

Fere greater. Those heating with natural gas and propane had expenditures close to the general

ationerage.

Residents of large multifamily units had average expenditures of $\$ 634,36 \%$ below the low-

$\because$ income average. This reflects the relatively small housing units they accupy, even though they tend

in to be concentrated in the coldest region. By contract, households living in single-family homes had ,

ies.

the

i in

Ids

nits

sw-

an average energy expenditure of $\$ 1,115$. Residents of mobile homes and small multifamily

- I buildings had average energy expenditures that were very close to the overall low-income population

An

Average.

$\because 4.4$

?at.

敉

Tncome.

The average income of "households" elegible for LIHEAP and Weatherization Assistance . ible $: 0 \%$

$\therefore$ trased on RECS data was $\$ 10,048$ in $1990 .^{2}$ This compared to an average income for all househoids in 1990 of $\$ 33,486$. Average homeowner incorne for eligible households was $\$ 10.989$ compared to 的 $\$ 9,095$ for renters.

-. Residential Energy Burden

$\therefore \quad$ "Energy burden" is calculated by dividing residential energy expenditures by income to express expenditures as a percentage of income. In many sespects it is the key meastre of the impact of energy costs on low-income households because it provides a measure, not only of energy costs, with

$\therefore$ but of affordability as well.

The average individual barden for all low-income households averaged $14.4 \%$ in 1990 . This is more than four times the burder for non-poor U.S. households which averaged $3.5 \%$. When measured as the ratio of the average of all low-income energy expenditures to the average of all lowincome incomes (group burden), the average energy burden for low-income households was $9.9 \%$, more than three times the burden for non-poor U.S. households when calculated in this manner. Please see the sidebar on the following page for an exptanation of alienative methods for calculating average energy burden as well as Table E.l, which provides a breakdown of energy burden, incorne, and expenditures by primary heating fuel type.

\section{Demographics of the Eligitle Population}

Households with elderly residents and those with chitdren are priority households for weatherization services under the law that authorizes the program. ${ }^{3}$ $\therefore$

2 Heusehold income in the RECS is actuatty family income and dots not include income from unrelared members : of the household. This contributes to lower income estimates in RECS than those in other surveys suct as the CPS or Survey of Incorne and Program Participation.

3 Households with persons with disabilities also are priority households, but RECS does not distinguish this Fi: ; subpopulation. 
Elderly -- Atnong all low-income households, 12.2 million (43.7\%) had at least one person classified as ejderly ( 60 or older). The average energy expenditure for households with an elderly member was $\$ 984$ in 1990, essentially the same as that of the lowincome population as a whole. The average energy burden for these households also was similar to that of all low-income households at $14.0 \%$ of income.

Children -- Approximately $43 \%$ of the program-eligible hotrsefiotds, or 12 mitlion, were households with children. The average energy burden for these households, at $14.0 \%$. was approximately the same as that for all lowincome households.

\section{Single-Parent -- These households} comprise a trique subset of the low-income househoids with childzen and are $19.9 \%$ of the total eligible population. Their energy burden was $18.0 \%$ of income in 1990 , which is higher than either of the priority groups.

\section{Program Participation}

An estimated 3.3 miltion households. [ $1.9 \%$ of al] eligible households, participated in the Aid To Families With Dependent Children (AFDC) Program, 2.3 million were reciptents of Supplemental Security Income (SSI) and 5.6 million, 20\%, were Food Stamp recipients. An estimated 3.8 million reported receiving heating assistance, (LIHEAP). These estimates from RECS, as well as other surveys such as Current Population Survey and Census.

\section{THE WHOLE PICTURE}

There are two principal ways in which average energy burden can be caictulated for a given group of housshokts. Ons of these celcudales energy burden for each household in a sample and then derives an average for these individual

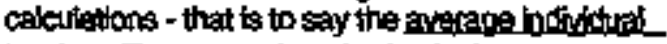
hutrden. The execond metrod calculetes everage erency expenciritures for all households th the group and divides this by the average of all income for the group; in athar words, the alosicos andinburdan.

Theses two methods provide remerkably ditterent tesilts, each of whish stys something important about the Impact of energy expendhures on lowitcorse budgeis. By the first method, the avernge incliydual burden, the mean energy busden for low-income housetsolos in 1990 was $14.4 \%$ of income. By the second method, the everage group burven, the masn energy burden for kwincome households was $9.9 \%$ of theortion. Why was there so coreat a difference between the ino?

In targe messute the difference can be explained by the tact that a substantlal mincity of iowincome hourseholds have energy expenditures thet far axceed the low-hrcome everage andior have incomes that are substantialy below the everage. The extreme burdente of these householids ent better tepresented by the burden Whan calculaded as an average of Individual houssobold burdens, or $14.4 \%$.

The sacond mathod, on the other hand, tends to better sellect the central tendercy of the whole group that is being meaguned. That is to sey, if comes closer to representing the erangy bunden for thoee households that ans neer the meditun of the group. Howrever, it says nothing about the mofividkas touseholds; it is a grocep statlstic.

In this report, which employs energy burden to

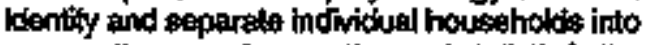
groups, the more frequently used stallsitc is the

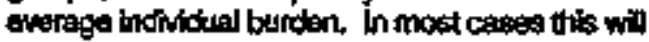
provide the reader with the sherpest contrast between the groups being described and compuered. Wherever posestole the report with aleo provide stalistles in th tables on avarage group burden so that the reeder can gel a balanted plature of the cemirat tendency and overati distibution of enengy burden for the populations being discussed. These stetistics with be destonetied as "Group burderl." 
tend to understate participation in all assistance programs when compated to participation as reported by administering program offices. Actual program participation was therefore significantly higher than these numbers would suggest.

Table E.1 lincome, Energy Expenditures and Energy Burden of Elgible Low-Income Househoids in 1990 (Source: 1990 RECS)

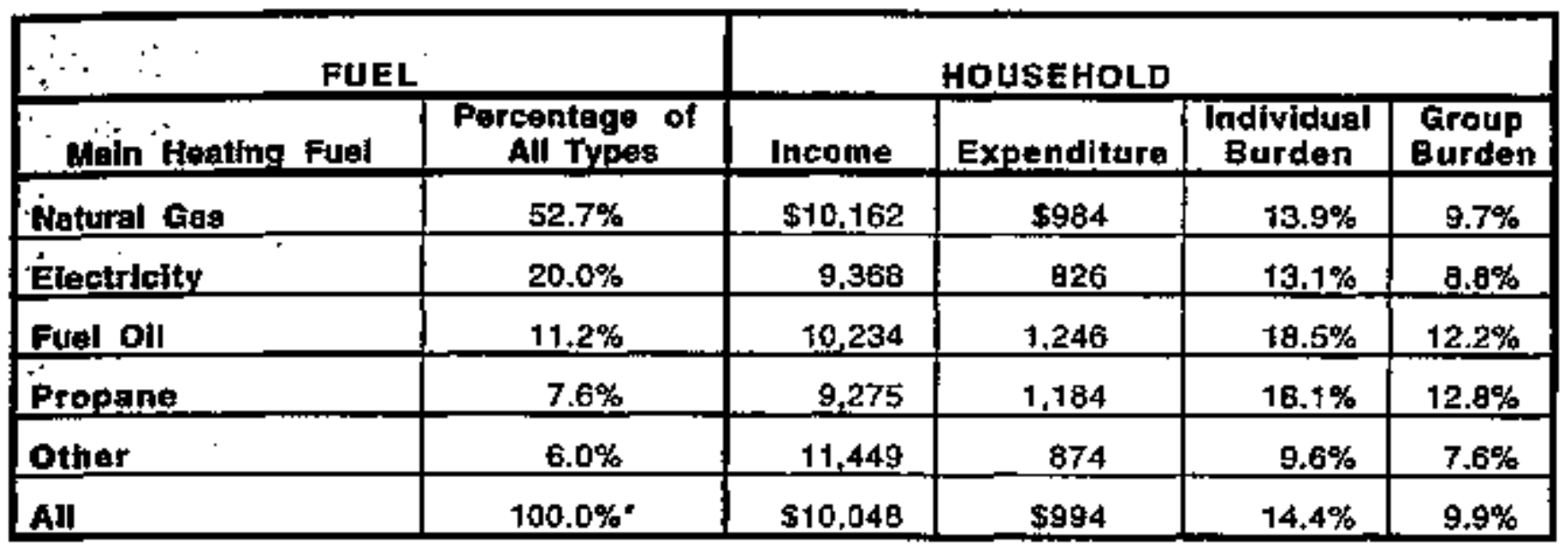

- Does not add to 100\% due to the exclusion of a separate line for kerosene which represents a small number of housetwolds. Kerosene was abt included in the calculation of "other" bul it was a component of the calculation of the overall average presented on the botion line.

\section{PROFILE OF THE HIGH-EXPENDITURE HOUSEHOLDS}

High-expenditure households were defined as those with average residential energy expenditures per beating degree day and square foot of ljving space that were one standard deviation or more above the mean for thetr region and temperature zone. This definition assures that the estimated 5.0 million households that fall into this category were derived from all regions and climate zones in the country. For maps of the climate and Census regions please see Appendix B.

\section{Expenditures, Income, and Burden of High-Expenditure Hotsseholds}

The mean energy expenditure for high-expenditure households was $\$ 1,233$ in 1990, which was substantially higher than the average for atl low-income households of $\$ 994$. Higher-thanaverage expenditures were not accompanied by higher-ihan-average incomes. The average incorne of high-expenditure households was less than the average for all tow-income housetiolds, 59,254 in 1990 compared to $\$ 10,048$.

The interaction of higher energy expenditures and lower incomes produced a mean energy burden for high-expenditure households in 1990 of $19.2 \%$, substantially higher than the $14.4 \%$ average for all low-income householdis. By the altemative standard, the group burden for these households was $13.3 \%$, compared to $9.9 \%$ for all low-income households. These households would 
therefore appear to offer both a solid energy-efficiency opportunity and a good target population for weatherization based on their need for lower energy burdens on household budgets.

Fut oil users had by far the highest average berden among the major heating fuel rypes at $27.3 \%$ of income. This compares to $21.0 \%$ for electricity users and [7.0\% for households heating with natural gas. Ptease see Table E.2 for details of energy expenditures and burden for the highexpenditure subgroup.

Table E.2 Income, Energy Expenditures and Energy Burden
of High-Expenditure Households in 1990

\begin{tabular}{|c|c|c|c|c|c|}
\hline \multicolumn{2}{|c|}{ FUEL } & \multicolumn{4}{|c|}{ HOUSEHOLD } \\
\hline Maln Heating Fuel & $\begin{array}{l}\text { Percentage } \\
\text { of All Types }\end{array}$ & Income & Expendtture & $\begin{array}{c}\text { Individual } \\
\text { Burden } \\
\end{array}$ & $\begin{array}{l}\text { Group } \\
\text { Burden }\end{array}$ \\
\hline Natural Gas & $47.2 \%$ & $\$ 9,30 t$ & $\$ 1.155$ & $17.0 \%$ & $12.4 \%$ \\
\hline Electriclty & $18.7 \%$ & 7.863 & 1.073 & $21.0 \%$ & $13.6 \%$ \\
\hline Fuel oll & $11.3 \%$ & 10,235 & 1.567 & $27.3 \%$ & $15.3 \%$ \\
\hline Propane & $17.4 \%$ & 9,817 & 1,343 & $16.5 \%$ & $13.7 \%$ \\
\hline Other & $\underline{5.4 \%}$ & 9,828 & 1,417 & $24.4 \%$ & $22.5 \%$ \\
\hline All & $100.0 \%$ & $\$ 9,254$ & $\$ 1,233$ & $19.2 \%$ & $13.3 \%$ \\
\hline
\end{tabular}

High-expenditure renters in large muttifamily buildings faced a bigh 22.3\% burden in 1990. This is in sharp contrast with the general low-income population, where the average burden for renters in large multifamily buildings was somewhat fower than the average for all hotseholds. The average expenditure for this group was $\$ 856$, well above the $\$ 633$ average for low-income renters in large buildings. Their average income, by contrast, was only $\$ 6,167$, compared to $\$ 7,978$ for all lowincorne renters in such butildings.

\section{Other Distingutishing Characteristics of High-Expenditure Hougeholds}

The proportions of futel use by type for high-expenditure households tends to be consistent with that of the general low-incone population. Natural gas was the dominant primary heating fuel, used by $47.2 \%$ of high-expendituse househotds, followed by $18.7 \%$ for electricity and $11.3 \%$ for home heating oil, The most striking figure was the proportion of high-expenditure households using propane- $17.4 \%$, compared to $7.6 \%$ for all low-income households.

In terms of demographics and program participation the high-expenditure households are not readily distinguishabile from alf low-income bouseholds as a group. For example, the proportion of low-income households with at least one person over the age of 60 among low-income highexpenditure households was $44.5 \%$, about the same as the proportion for the low-income population 
as a whole. Among high-expenditure households the rate of participation in basic public assistance programs was roughly comparable to that for the low-income population as a group.

\section{PROFUL OF THE HIGH-BURDEN HOUSEHOLDS}

\section{Expenditure, Income, and Burden Characteristics of Figh-Burden Households}

High-burden households comprised 7.2 million of the 27.9 million households federally eligitble for weatherization in $1990,26 \%$ of the total. They were defined as those househoids in the low-income population with energy burdens, measured as household energy expenditures divided by household income, that were one stancard deviation or more above the mean for all households in their Census Divisions and climate zones.

Though fuel-use pattens were similar to those of all low-income households, high burden households had higher-than-average residential energy expenditures. The mean residential energy expenditure for all bigh-burdes households was $\$ 1,175$, statisticalty comparable to that for highexpenditure households, which was $\$ 1,233$ in 1990.

The single characteristic that most distinguishes high burden households from low-income households in general is income. The average income of these households was only $\$ 5,419$ compared to $\$ 10,048$ for all low-zicome households in 1990 . As one might expect, the energy burden figures for this groug are starting. The average burden nationwide was $30.1 \%$, compared to $14.4 \%$ for all low-income households. When measured by the altemative method, the group burden, the burcen for these households averaged $21.7 \%$ of income, more than twice the $9.9 \%$ average for all low-income households.

Indeed, the relationship between high burdens and low incomes is further demonstrated by an analysis of energy burden by income group. This zeveals that the average burden for all households with incomes at or below $\$ 5,000$ in 1990 was $33 \%$ of income, rougily comparable to the average burden calculated for the high-burden households and reflecting the significant overlap of the two groups. Please see Table E.3 for further details of income, expenditures, and burdens for highburden households.

\section{Distinguishing Characteristics of the Eigh-Burden Population}

There was little to distinguish the high-burden hotsseholds from other low income households in terms of their demographics. The elderly compromise $41.3 \%$ of the high-burden population, and households with children were $39.9 \%$ of the total. These proportions are comparable to those for the low-income population as a whole. The proportion of single-parent housefolds was higher in the high-barden population than among low-income households in general. 
Table E.3 Income, Energy Expenditures and Energy Burden of High-Burden Households in 1990

\begin{tabular}{|l|r|r|r|r|c|}
\hline \multicolumn{2}{|c|}{ FUEL } & \multicolumn{4}{c|}{ HOUSEHOLO } \\
\hline $\begin{array}{c}\text { Mein Heating } \\
\text { Fuel }\end{array}$ & $\begin{array}{c}\text { Percentage } \\
\text { of All }\end{array}$ & Income & Expendfture & $\begin{array}{c}\text { Individual } \\
\text { Burden }\end{array}$ & $\begin{array}{c}\text { Group } \\
\text { Burden }\end{array}$ \\
\hline Naturat Gas & $49.4 \%$ & $\$ 5,598$ & $\$ 1,150$ & $28.8 \%$ & $20.5 \%$ \\
\hline Electrlcity & $17.3 \%$ & 4,240 & 954 & $30.8 \%$ & $22.5 \%$ \\
\hline Fuel OII & $15.6 \%$ & 5,865 & 1,422 & $34.0 \%$ & $24.2 \%$ \\
\hline Propane & $10.9 \%$ & 5,712 & 1,324 & $30.5 \%$ & $23.2 \%$ \\
\hline Other & $5.9 \%$ & 4,475 & $1,0 \% 7$ & $31.6 \%$ & $19.0 \%$ \\
\hline All & $100.0 \%$ & $\$ 5,419$ & $\$ 1,175$ & $30.1 \%$ & $21.7 \%$ \\
\hline
\end{tabular}

* Does noc sutn due to rounding.

Their rate of participation in public assistance programs was substantially above that of all low-income household for certain key programs. Approximately $22.6 \%$ of these households were AFDC recipients compared $1011,9 \%$ of all the poor who received those benefits. An estimaled $22.7 \%$ received LIHEAP benefits compared to $13.8 \%$ of all the poor. The Food Stamp participation Fate was $33.3 \%$ compared to $20 \%$ for all the poor.

\section{PROFILE OF THE HIGH-BURDEN/HIGH-EXPENDITURE POPULATION}

Households that are both high-expenditure households and high-burden households are of particular inlerest to those concerned with targeting wealherization for maximum energy efficiency and equity benefits. These are households that were as least one standard deviation above the means in their Census Division and climate zone in both energy burden and heating expenditure per heating degree day and square foot of living space. An estimated 2.1 million households fitted into this category in 1990. These were $42.6 \%$ of all high+expenditure households and $29.3 \%$ of all highburrden households.

\section{Housing Charactertstics of High-Burden/High-Expenditure Households}

An estimated $51.4 \%$ of the bigh-burden/high-expenditure households lived in single-family homes, $19.3 \%$ lived in small multifamily dwellings and $17.5 \%$ in mobile homes. The percentage living in large multifamily buildings was $11.8 \%$. These statistics indicate that the high-burden/highexpenditure population are more heavily concentrated in small multifamily dwellings and mobile homes and less likely to live in single-family units and large apartment buildings than the low-income population as a whole. 


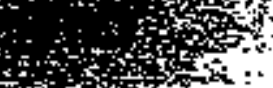

Fingry Feating Fuels of High-BurdenfHigh-Expenditure Households

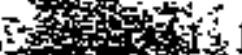

Natural gas was the single most significant fuel for heating in this population, with $40 \%$ using if niationwide. This proportion is substantially below that for the low-income population as a whole. Eletricity was used for heating by $25.3 \%$. fuel oil by $13.1 \%$ and propane by $16.6 \%$ of the Hoajsholds. The proportion of households using propane was more than twice the proportion doing in all low-income bouseholds.

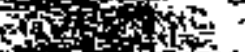

(s)

Binet Expenditures and Income

Fy

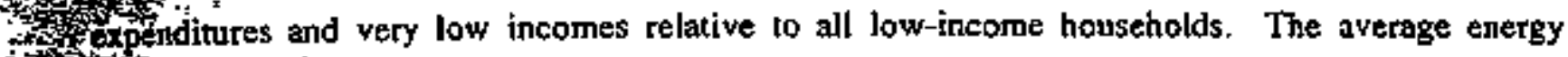
$\rightarrow$ in

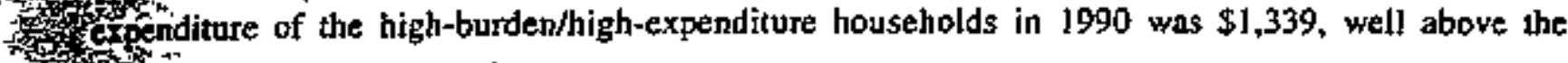
therige for all Jow-jncome households of $\$ 994$. Households in the high-burden/high-expenditure

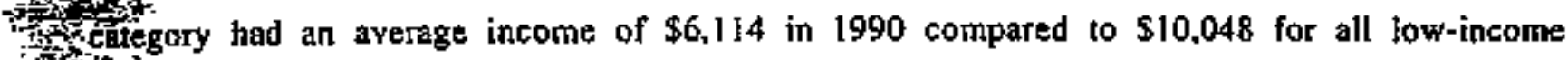
, t s. Households.

is

i ?

The energy busden for high-burden/high-expenditure households averaged $30.4 \%$. a figure

comparable to that for high-burden households and well above the average for high-expenditure 政: 1

势

ave tor all low-income households.

'Pis.

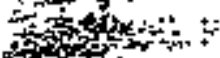

\section{SOTHER POPLIONS OF INTEREST} The research tearn identified three other subpopulations of low-income households that could
. poteptially pcovide additional insights into the best ways to targer weatherization assistance. The first $\therefore$ poteptially provide additional insights into the best ways to targer weatherizaion assistance. The first - subset consists of households with housing characteristics that might indicate the need for Weatherization, i.e. "low-efficiency" households. The second subset consists of those households that Were qualified for assistance in both 1987 and in 1990 - "persistent-eligible" households. The third subset consists of bouseholds weatherized in 1990.

Law-Efriciency Households

Low-efficiency households were defined as those households nationwide who reported little - or no attic insulation as well as those in the Northeast and Midwest having storm windows on less than $25 \%$ of their windows. These comprised 4.6 million households across the country.

$+i^{i}$; An estimated $73 \%$ of low-efficiency households lived in single-family units, weil above the . national average for all low-income households. The average residential energy expenditure for the subset was $\$ 1,084$ and the average energy burden was $15.9 \%$ of income. Neither statistic distinguishes these households from the overall low-income population. This probably indicates that 
these "efficiency" eharacteristics as surveyed in RECS are not adequate indicators of energy efficiency in the sample housing stock.

\section{Persistent-Eligible Households}

According to RECS data, there were $[7.3$ million households that qualified for weatherization in both 1987 and 1990 . The persistence of their poverty over time makes them a natural target group for energy-efficiency programs.

These households were $20 \%$ more likely to have an elderly member and $33 \%$ more likely to have an African-American member then at] low-income households. The average residential enengy expenditure for the persistent-eligible households was $\$ 990$, essentially the same as the "1990-only" households. The average burden was also comparable to that of all eligible households.

Though they are therefore not distinguisted from other low-income households by these energy ctiteria, persistent-eligible households may deserve prioritization because their energy affordability problems seen less likely to be resolved by a positive change in their financial circumstances then other househoids.

\section{Households Weatherized in 1990}

Households weatherized during the year previous to the 1990 RECS comprised so small a sample within the survey that any effort to draw meaningful comparisons between these households and the low-income sample was extremely limited.

\section{COMPARISON OF THE POPULATIONS OF INTEREST AND SUMMARY}

A comparison of key statistics from the major subsets and for the eligible population as a whole indicate that in many respects there is remarkable consistency among the high-burden and high-expenditure subgroups relative to the overall low-income population. The outstanding characteristics that distinguish the subgroups are the characteristics that define them, namely energy expenditures for the high-expenditure group and income for the high burden group.

\section{Hoosing Type and Tenure}

The major distinctions in housing type concern high-expenditure households. Mobile homes are nearly $20 \%$ of the high-expenditure subgroup though they comprise only $8.2 \%$ of all eligible households and $8.5 \%$ of high-burden households. Large multifarmily dwellings are a significantly smaller proportion of this group than of the overall fow-income housing stock. Mobile home residents may therefore be a subpopulation of particular interest from an energy efficiency perspective. Please see Figure E.2 for details. 


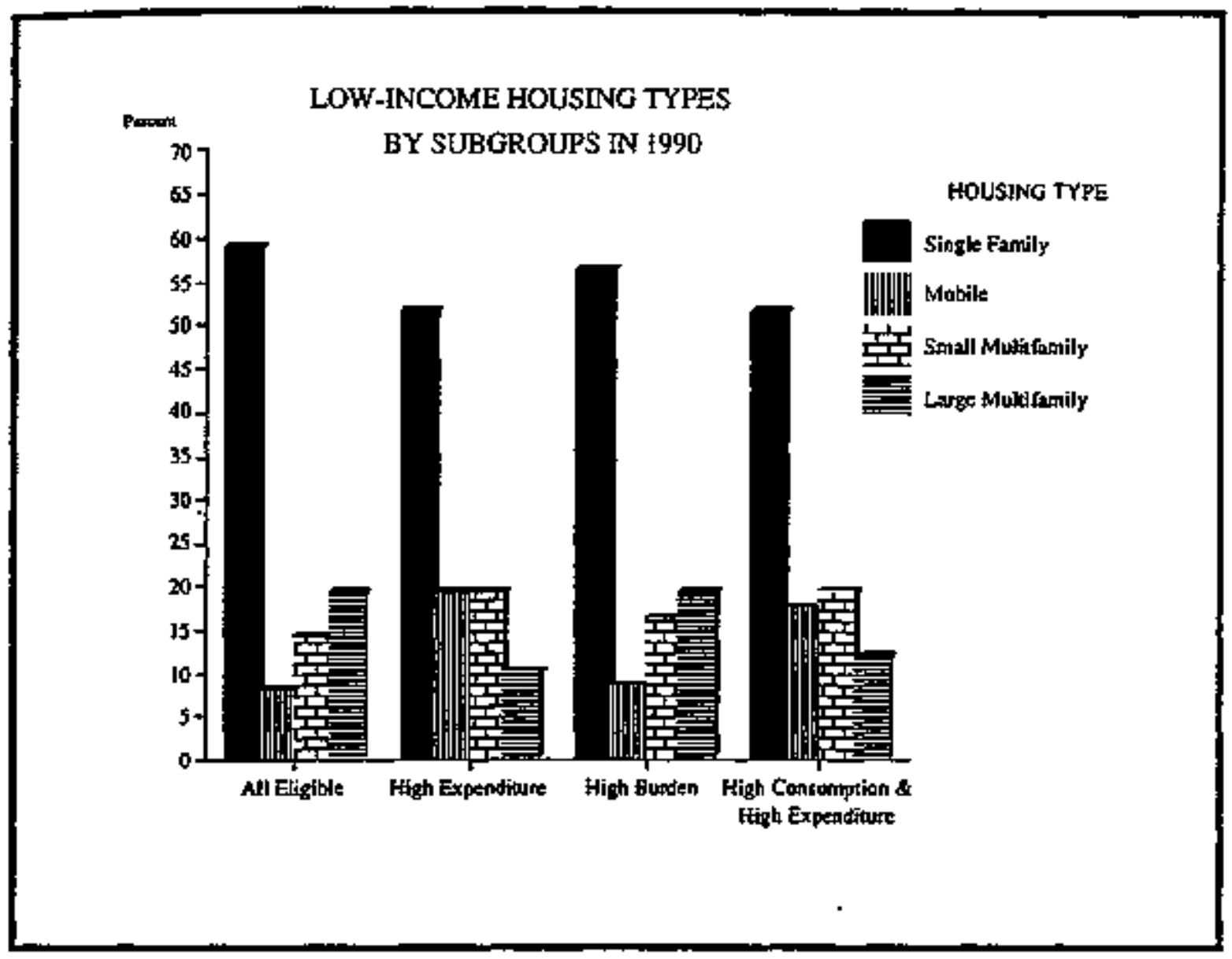

Figure E.2 Low-Income Housing Types by Subgroups in 1991

Demographics and Program Participation

High-burden households have a higher rate of participation in AFDC, LIHEAP, and Food Stamps than daes the eligible population as a whole. LIHEAP participation rates in particular are much greater for high-burden househoids than for all low-income households, a result that is consistent with the legisfative mandate of that program to serve households with the greatest energy burdens. African-American households are dispropontionatedy represented in the high-expenditure and high-burden populations. Other demographic characteristics, such as the presente of elderly persons, childinen, or single-parent families do not vary among the subgroups and eligible population to any significant degree.

\section{Statistical Summary of Income and Energy-Related Characteristics of Low-Income Households}

1) The average income for eligible households was $\$ 10,048$ in 1990 , approximately 30\% of the average income for all U.S. households. 
2) Mean income for high-expenditure househoids was $8 \%$ below the average for all low-income househoids. This indicates that their higher expenditures were not a function of relatively higher incone compared to other poor households.

3) High-burden households, with an average income of only 55,419, were clearty disadvantaged, even refative to other fow-income households.

4) Low-income households had an average residential energy expenditure of $\$ 994$ in 1990. 15\% below the rational hotsehold average.

5) The average residential energy expenditure by high-expenditure househoids, at $\$ 1,233$, was $24 \%$ greater than the low-income average and also exceeded the national household average.

6) High-burden households, despite their lower incomes, had an average residential energy expenditure of $\$ 1, \$ 75$. comparable to that of high-expenditure households.

7) The average individual energy burden of eligible househoids was $14.4 \%$ of income in 1990, well above the national average for non-poor households of $3.5 \%$.

8) High-expendjture households, with an average burden of $19.2 \%$, were more heavily burdened than the average low-income household and high-burden bouseholds were expending an onerous average of $30.1 \%$ of their income for residential energy. Please see Figure E.3.

9) Approximately $43 \%$ of the high-expenditture households, 2.I mitlion, are also in the high-burden category. These households are particularly worthy of greater attention in that they appear to offer a major energy efficjency and equity opportunity.

10) For high-burden/high-expenditure households the average residentia] enecgy expenditure was $\$ 1,339$ and the average burden was $30.4 \%$ of income.

11) An emphasis of weatherization efforts on this 2.1 million would place greater focus on mobile homes and small multifamily dwellings. Households heated with propane and renters in single-family units would also receive more emphasis.

A logical target for future research is a more in-depth evaluation of the demographics, location, housing, and energy proftie of the high-burden/high-expenditure group. This may prove useful to state, community, and utility weatherization specialists who are trying to maximize both the equity and efficiency retums to scarce weatherization dollars. 


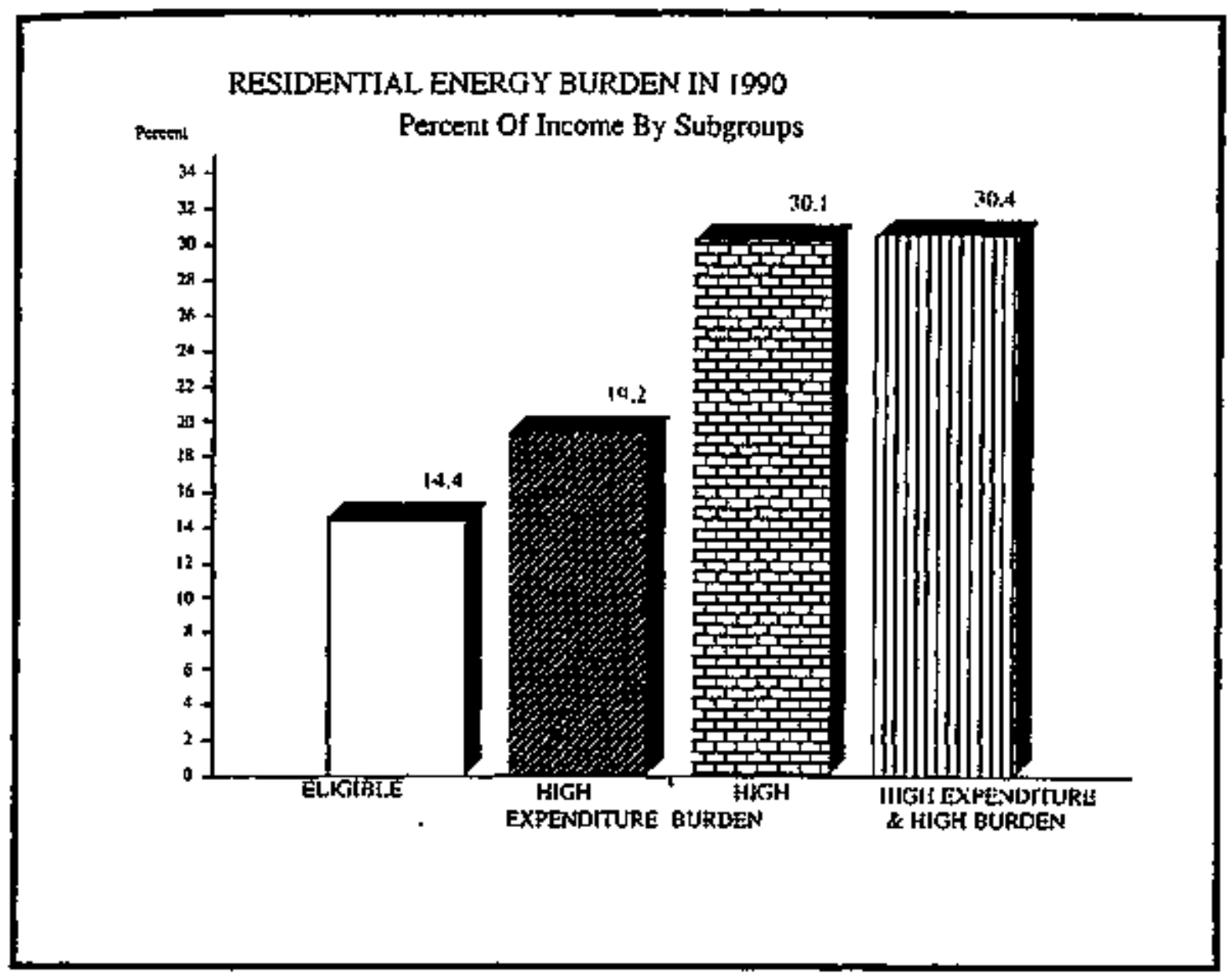

Figure E 3 Residential Energy Burden by Subgroups in 2990

s.

ve

he 


\section{l. INTRODUCTION}

The U.S. Department of Energy (DOE) is conducting a national evaluation of its Weatherization Assistance Program (DOE/WAP), an energy-efficiency program that provides financial assistance to qualifying low-income households for the "weatherization" of their housing units. The evaluation, being conducted for the Department by Oak Ridge National Laboratory (ORNL), is comprised of tive studies. Three of these studies focus on principal Weatherization Assistance Program submarkets:

- single-fanidy fuel-oil homes (the Fuel-Oil Study -- Temes and Levins, 1993);

- single-family and small multifarnily homes using gas and electricity the SingleFamily Study -- Brown et al., 1993); and

- high-density multifamily buitoings-- (the Multifamily Study -- MacDonald, 1993).

The remaining two studies investigate issues that are important for planning and assessing opportunities for innovation, new initiatives, and resource leveraging.

- a description of the Weatherization Assistance Program network's characteristics and innovations; and

- an analysis of the scope of the Weatherization Assistance Program, dwellings weatherized to date, and the population remaining to be served, referted to below as the "Scope" study.

The first part of the "Scope" study, entiled The Scope of Weatherization Assistance Propram: The Weatherized_Popniation and the Resource Base (Power, ec.al., 1992) has been compieted, it describes the size and sousces of the investment made in low-income weathecization from Program Year 1978 through 1989, the number and types of homes weatherized, and the extent to which nonDOE Weatherization Assistance Program funding has been mobilized.

This is the second part of the "Scope" study which investigates the characteristics of the population eligible for and in need of the DOE Weatherization Assistance Program - The Profile of the Population_in_Need, The "Profile" study is an attempt to use major national survey resuits from the Residential Energy Consumption Survey (RECS) for 1990 and other sources to define the weatherization-related chacacteristics of the low-incone population.

\subsection{RESEARCH OBJECTIVES}

The Profile of the Population in Need describes the gopulation of iow-income households, their location, housing attributes, energy-use and demographic characteristics. The study's intent is to highlight those attributes that shed some light on the need for low-income energy efficiency services among those households that may qualify under national income standards for the 
Weatherization Assistance Program and the Department of Health and Human Services' Low Income Home Energy Assiskance Program (LIHEAP). The income standard for LIHEAP is the greater of 60 percent of state median income or 150 percent of the poverty level. The income standard for the Weatherization Assistance Program is at or below 125 percent of the poventy level; however. a state may elect to nse the LIHEAP income standard if its states LIHEAP income standard is at least 125 percent of the poverty level. I

The study forther seeks to examine the characteristics of several subsets of the eligible lowincome population for purposes of refining the understanding of how best to target and allocate limited weatherization resources.

Among the subsets of the eligible population examined in this report are the following:

1) "High-Expenditure" Households -- These were eligible households with space heating expenditures per square foot of living space that were at least one standard deviation above the average relative to other households located in the same Census Division and heating-degrec-day zone. ${ }^{2}$

2) "High-Burden" Household -- These were household with residential energy expenditures in proportion to income that were at least one standard deviation above the average relative to other low-income households located in the same Census Division and heating-degret-day zone.

3) "High-burden/High-expenditure" Households -- These were households that beionged to both the high-burden and high-expenditure sets defined above.

4) "Persistent-Eligibie" Households .. These were households that were federally eligible for participation in the Weatherjzation Assistance Program in bath 1987 and 1990. Federat eligibility is defined as the higher of $150 \%$ of the federal Poverty Level or $60 \%$ of State median income. The most recent previous Residential Energy Consumption Survey was conducted in 1987.

5) "Weatherized" Households -- These were households that responded "yes" when asked if they had received government weatherization assistance during the previous year in the I990 RECS. No particular govemment agency or program was specified in the RECS qrestion.

In the previously completed section of the scope study. "The Weatherized Population and The Resource Base," it was estimated that 3.9 million housing units had been weatherized through Program Year 1989. In an ideal world it would be possible to examine these households that had

\footnotetext{
I For this study, the fiscal year 1990 state median income eslimales and the calendar year 1989 poverty income gutidelines were used with the 1990 RECS poptlation and income data in classifying low income housetolds.

1 A standard deviation is a melasure of the degrec to which a set of uumbers varies fron the avernge for the sel.
} 
trceived weatherization assistance and those that have not received it as separate subsets of the same data basc. This would pennit profiles to be created of both the "served" and "not-served" populations that are eligible for Weatherization Assistance Program.

Unfortunately there is no data base that identifies energy and housing characteristics for alt weatherized households. The RECS does ask questions regarding weatherization assistance over the year previous to the survey, but no data is provided on households weatherized in previous years.

Furthermore, the dynamics of income and poverty are such that a substantial number of households that are eligible for the program in one year are not eligible in later years. Conversely new households that were not poor enough to qualify for program services in one year find their income drops below the qualification level in later years. Consequently an estimated 38.7 mitlion households were federally qualified to receive Weatherization Assistance Program services in either 1987 or 1990 or in both years, though the count of eligitble households in 1990 was 27.9 million. Simply put, the number of households that has received Weatherization Assistance Program services is small relative to the eligible and potentially eligible pool of households.

In light of these realities this study describes the total eligible population in 1990 as welt as subsets of interest with the understanding that some of these households have aiteady been weatherized. The expectation is that these households are few enough in number so as not to distort conclusions drawn regarding segments of the eligible population that appear in need of weatherization. Sorme statistics are provided conceming weatherized households from the 1990 RECS so that the rearder may compare and contrast the data,

\subsection{OUTLINE OF THE STUDY}

The second chapter of the profile study provides an in-depth description of the eligible households based on the 1990 RECS. The description includes a breakdown of these households by primary heating fuel type. housing type and tenture, by region, and by key demographic and program participation characteristics. Energy expenditures, household income, and energy burden statistics for the group and major subclassifications are then provided.

The third chapter provides a detailed description of those householdis defined as "highexpenditure". These housefolds are logical targets for weatherization services and energy efficiency opportunities given their relatively high energy expenditures, adjusted by living space and temperature, compared to others in the eligible population. This chapter describes energy expenditure, household income, and energy burden characteristics for these households. An overview of key housing, fuel type, demographic, and program participation characteristics, is also provided.

The fourth chapter describes key characteristics for two subpopslations: "high-burden" households and "high-burdenhigh-expenditure" households. The high-burden population is 
generally considered to be a priority population for energy assistance and weatherization based on equity grounds. The high-burden/high-consumption household subset provides an opportunity 10 determine the degree to which a set of high priority households emerge from the data chat are exceptional weatherization candidates based on both their energy efficiency potential and the heavy burden they face because of their higher energy costs relative to income.

Chapter five describes key characteristics and conclusions that emerged from an examination of othes subpopulations. These include:

- the "persistent-eligible" households for both 1987 and 1990 ,

- the weatterized households from the 1990 RECS, and

- those housetholds with "low efficiency" characteristics in their housing, based on the limited data avajlable in RECS regarding insulation and storm windows.

Chapter six provides a comparison of key statistics from the major subsets and for the eligible population as a whote. In this chapter conclusions based on the statistics and comparisons are offered. Suggestions are also made regarding areas in which further research may be productive.

The study concludes with appendices that provide detailed tables for the key subpopulations as welf as an in-depth description of the RECS.

\subsection{METHODOLOGY AND LIMITATIONS}

The core of the study rests on a series of cross tabulations and statistics derived from the 1990 Residential Energy Consumption Strvey. The RECS is the best available resource offering household data on residential energy use in combination with information on family income, housing type, tenure, fuel type, and over 400 other variables. The reliability of RECS lies in its collection of actual energy consumption and expendjure data from fuel vendors racher than estimates or recollections from nembers of the survey housetholds.

However there are limitations to the RECS data that need to be recognized. First, the survey is relatively small. In 1990 there were 5,095 households that contribuled data to the survey. The lowincome eligible households comprised approximately 1,500 households of this cotal. Though the statistics in the tables are presented in terms of millions and hundreds of thousands of households, the underlying statistical base is small. The finer the statistic in terms of the precision of location, fuel type, and other characteristics, the more tikely it is to rest on a relatively small strvey base, Statistics were screened to limit the possibility that interesting bot statistically insigniftcant comparisons and conclusions would be drawn. The reader is nonetheless warned to exercise care in using and comparing data from smatl populations presented in the Appendices, particularly for regional breakdowns of the population subsets. 
Second, incorne data from RECS tends to be less reliable than the data that can be derived from the Current Popuiation Survey (CPS) or the Survey of Income and Program Participation conducted by the Census Bureat. Indeed, when statistics are derived by the Department of Health and Humans Services for energy burden for low-income housebolds and Low-Income Home Energy $\because "$ Assistance recipients for the annual report on the Low Income Home Energy Assistance Program, the A in

income data.

In this study the research team decided to use the less precise data in the RECS itself rather -than the CPS in order to define the subpopulations of interest, particularly the high-burden and high$\therefore$ burden/higkexpenditure sets. This could not have been done using the broad population averages r. derived from the CPS.

$\therefore$ The reader should keep in mind the tendency of RECS income data to under-report household income to some degree. This under-reporting is most evident in high income categories. There is a tendency to over-report the lowest income categories as well. This would result in an overestimation of households eligible for the program when compired to the estimates from CPS. The total of households eligible for the program based on RECS is 27.9 milition. 2.5 mitlion higher thas the CPS equivalent.

$=\ddot{7 .}$. 


\section{RESIDENTIAL ENERGY USE CHARACTERISTICS OF THE LOW-INCOME POPULATION}

In 1990 there were an estimated 27.9 million households that were federally quatified for the LIHEAP and DOE/Weatherization Assistance Program programs. These were households with incontes at or below the higher of $150 \%$ of the federal goverament's Poverty Level for that year or $-60 \%$ of their state's median income. The federally eligible households comprised $29.7 \%$ of all U.S.

i households, which totalled 94.0 million in 1990 . In the balance of the report these households will $\therefore$ is

. be referred to as the "eligible" or "law-income" population.

\section{-2.1 HOUSING CHARACTERISTICS}

Low-income households, like the population at Jarge, tend to reside in single-family homes. 'In fact, $58.7 \%$ lived in single-family houses and an additional $8.2 \%$ lived in mobite homes. Of the remaining households, $19.1 \%$ lived in large multifamily dwellings and $14.1 \%$ oceupied aparments in $\therefore$ small multifamily buildings of two-through-four units. The proportion of low-income. households living in single-family homes is somewhat lower than the proportion for all U.S. households and that living in multifanily or mobite homes somewhat higher. For details. please see Tables 2.1 and 2.2 .

Table 2.1 Housing Types for Low-Income Househoids Thousands of Households in 1990

\begin{tabular}{|l|c|c|c|c|c|}
\hline & $\begin{array}{c}\text { Single } \\
\text { Femijy }\end{array}$ & Moblle & $\begin{array}{c}\text { Small } \\
\text { Mulifamily }\end{array}$ & $\begin{array}{c}\text { Large } \\
\text { Multifamily }\end{array}$ & Total \\
\hline NORTHEAST & 2,193 & 794 & 1,477 & 1,409 & 5,273 \\
\hline MIDWEST & 4,065 & 537 & 985 & 832 & 6,454 \\
\hline SOUTH & 7,065 & 907 & 835 & 1562 & 10,368 \\
\hline WEST & 3,032 & 602 & 643 & 1,510 & 5,768 \\
\hline U.S. & 16,335 & 2,277 & 3,938 & 5,313 & $27,8 B 3$ \\
\hline
\end{tabular}

i. There is substantial variation among the Census regions in the housing types occupjed by low-income households. Of the 10.4 million low-income households in the South, $68.1 \%$ lived in single-family housing and $15 \%$ lived in large multifamily buildings in 1990 . In the Northeast on the other hand, only $4 \mathrm{~L} .6 \%$ of the 5.3 million low-income households lived in singie-family homes while $28 \%$ lived in smatl multifamily buildings and $26.7 \%$ lived in large muitifamily buildings.

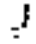


Table 2.2 Housing Types for Low-Income Households Percent of Households in 1990

\begin{tabular}{|l|c|c|c|c|c|}
\hline & $\begin{array}{c}\text { SIngle } \\
\text { Family }\end{array}$ & Mobile & $\begin{array}{c}\text { Small } \\
\text { Multlfamily }\end{array}$ & $\begin{array}{c}\text { Large } \\
\text { Multifamill }\end{array}$ & Total \\
\hline NORTHEAST & $41.6 \%$ & $3.7 \%$ & $28.0 \%$ & $26.7 \%$ & $100 \%$ \\
\hline MEDWEST & $63.0 \%$ & $8.9 \%$ & $15.2 \%$ & $12.9 \%$ & $100 \%$ \\
\hline SOUTH & $68.1 \%$ & $8.8 \%$ & $8.1 \%$ & $15.1 \%$ & $100 \%$ \\
\hline WEST & $52.4 \%$ & $10.4 \%$ & $11.1 \%$ & $26.1 \%$ & $100 \%$ \\
\hline U.S. & $58.7 \%$ & $8.2 \%$ & $14.1 \%$ & $19.1 \%$ & $100 \%$ \\
\hline
\end{tabular}

In the Midwest, single-family occupancy was the housing type for $63 \%$ of the 6.5 million households, where as in the West, the proportion in single-faraily dwellings was only $52.4 \%$. Households in the West occupied units in large multifamily butildings in $26 \%$ of the cases whereas in the Midwest the proportion was only $12.9 \%$. In the West over $10 \%$ of tow-income househoids lived in mobile homes.

\subsubsection{Tenure}

Approximately $50.3 \%$ of low-income households owned their own homes in 1990 . The vast majerity of homeowners, $82.6 \%$, lived in single-family units but a Jarge number, 11.4\%, were in nobile homes. There were 13.9 million low-income rencer households in 1990 and $34.4 \%$ of these lived in single family houses. An additional $37.3 \%$ lived in large multifamily buildings and $23,4 \%$ rented in smail multifamily buildings. Please see Appendix A. Table A-1 for details.

There was substantial contrast armong regions when housing tenure was considered. In the Northeast, only $44.7 \%$ of low-income households owned their own homes in 1990 whereas in the Midwes the proportion of owners was $58.3 \%$. In the South $56.5 \%$ of low-income households owned their own homes, but in the West only $35.4 \%$ were owners.

\subsubsection{Heating Fuel}

The pattem of primary fuel use among the poor generally followed that for the population at large with 14.7 million, 52.7\% of low-income households, heating with natural gas as compared to 55\% of all U.S. households that used gas heating. Twenty percent of law-income households heated with electricity as compared to $23 \%$ of the general population. Fuel oil was used by $11.2 \%$ of the poor for heating and $1.2 \%$ used kerosene, percentages that are comparable to the proportions of all households using those fuels. The use of jiquifted petroleum gas (propane) was more common among low-income housetolds than in the popslation at large. The percentage of households 
heating with propane among all U.S. households was only $4.7 \%$ compared to $7.6 \%$ for low-income households.

The pattem of heating fuel use among low-income consumers varies significantly by region. In the Northeast, $38.7 \%$ of households heated with fuel oil and electricity was a much less significant primary heat source then it was th other parts of the country. Onfy $8.8 \%$ of the region's poor households heated with electricity and less than $1 \%$ heated with propane. In the Midwest, on the other hand, $67.1 \%$ of, all low-income households heat with natural gas and $10.8 \%$ use propane for . heat. Only $7.9 \%$ of low-income housekolds in the region heated with electricity and just $6 \%$ heated with fuel oil. Please see Figure 2.1 for details.

ton

\%.

in

'ed

ast

$\cdot$ in

ese

$4 \%$

the

the

ned

In at

Peneter

MAIN HEATING FUEL BY REGION

${ }^{80}$ - Percent Of Low-Incorne Households In 1990

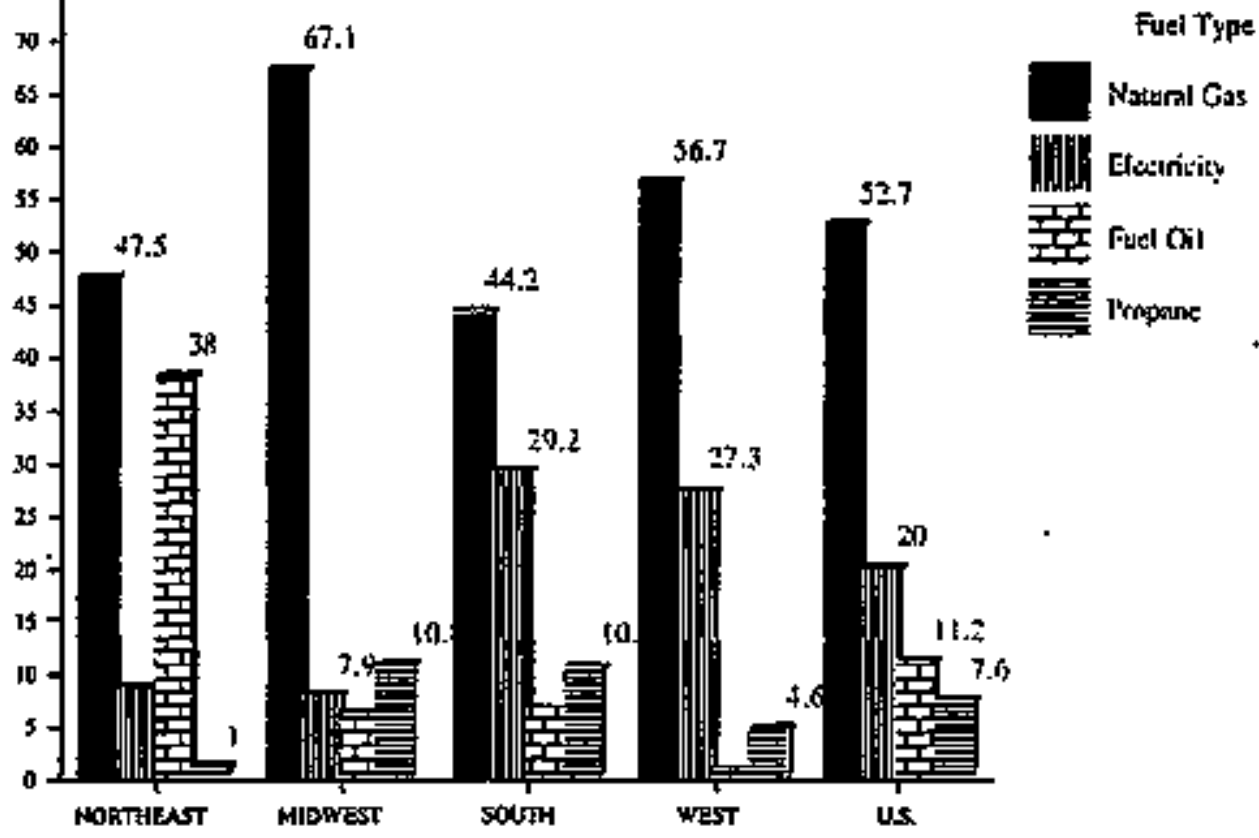

d to

ated

$i$ the

if all

imon

folds

Figure 2.t Main heating Fuel by Region

These patterns reflect the historical development of energy markets in which naturat gas pipelines were quick to expand to the Midwest but not to the Northeast, which was further from the natural gas fields. In both regions electricity has been an expensive commodity relative to altemative energy sources.

$\therefore$ 
In the South and West, on the other hand, electrictity is far more common as a heating fuel. Twenty-nine percent of low-income households in the former and $27 \%$ in the latter used electricity for heat. Propane was used by $10.6 \%$ of the Southen poor but oaly $4.6 \%$ of those in the West. A signiftcant number of Southem households. 6.6\%, use fuel oil for heat, whereas in the West less than $1 \%$ did so. Natural gas, which heated $56.7 \%$ of the households in the region, was the dominant heating fuel in the West.

\subsection{ENERGY EXPENDITURES}

In 1990 the average low-income household spent $\$ 994$ for residential energy, but there was substantial variation by fuel type, housing type and region. In fact, the standard deviation for energy expenditures by low-income households was $\$ 495$. Thus, while approximately two thirds of all lowincome houscholds in the sample had expendittres ranging from $\$ 499$ to $\$ 1,489$, a significant number of the households actually had expenditures that were lower or higher than these figures.

The average residential energy expenditure for low-income housenolds was lower than that of all U.S. households. The mean expenditure in 1990 for all housetiolds in the country was $\$ 1,172$, $18 \%$ higher than the low-income average. Similar differences exist between the low-income and general populations for eact primary heating fuel type as well. Low-income housing, is generally smatler than that of the general population. This, combined with lower disposable income, helps explain the difference is absolute expenditure ievels. However, it should be kept in mind that the $18 \%$ gap between all household expenditures and low-income household expenditures is not proportionat to the gap between average household incorne and that of the poor. Avecage household income was three times greater than the fow-income average in 1990.

The broad range of expenditures and the significant number of houșeholds with residential energy costs well above the average, as shown in the next chapter, rellects the degree to which temperature, housing quality and type, fuel type, fuel cost, and household characteristics combine in countless variations to determine the cost of residential entergy.

Some patterns regarding energy expenditures do emerge from the data. Households heating with electricity tended to have much lower average residential energy expenditures than the lowincome population as a whole at $\$ 826$, whereas those heating with fucl oil had the highest expenditures, at an average of $\$ 1,246$. Those using kerosene or propane as their primary heating fuel also averaged in excess of $\$ 1,150$ in expenditures. Households heating with natural gas had average expenditures of $\$ 984$.

Not only did residential energy expenditures vary by fuel type but by housing type as well. Residents of large multifamily units had ayerage expenditures of $\$ 634$ whereas those in single-family homes averaged $\$ 1,115$. Mobjle home dwellers and those in small multifamily units averaged $\$ 978$ 
Stive

Fos respectively. For further details concerming average expenditures by fuel and housing itype please see Table 2.3 and Appendix A, Table A-11.

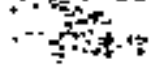

Table 2.3 Average Residential Energy Expenditures

Low-Income Households in 1990

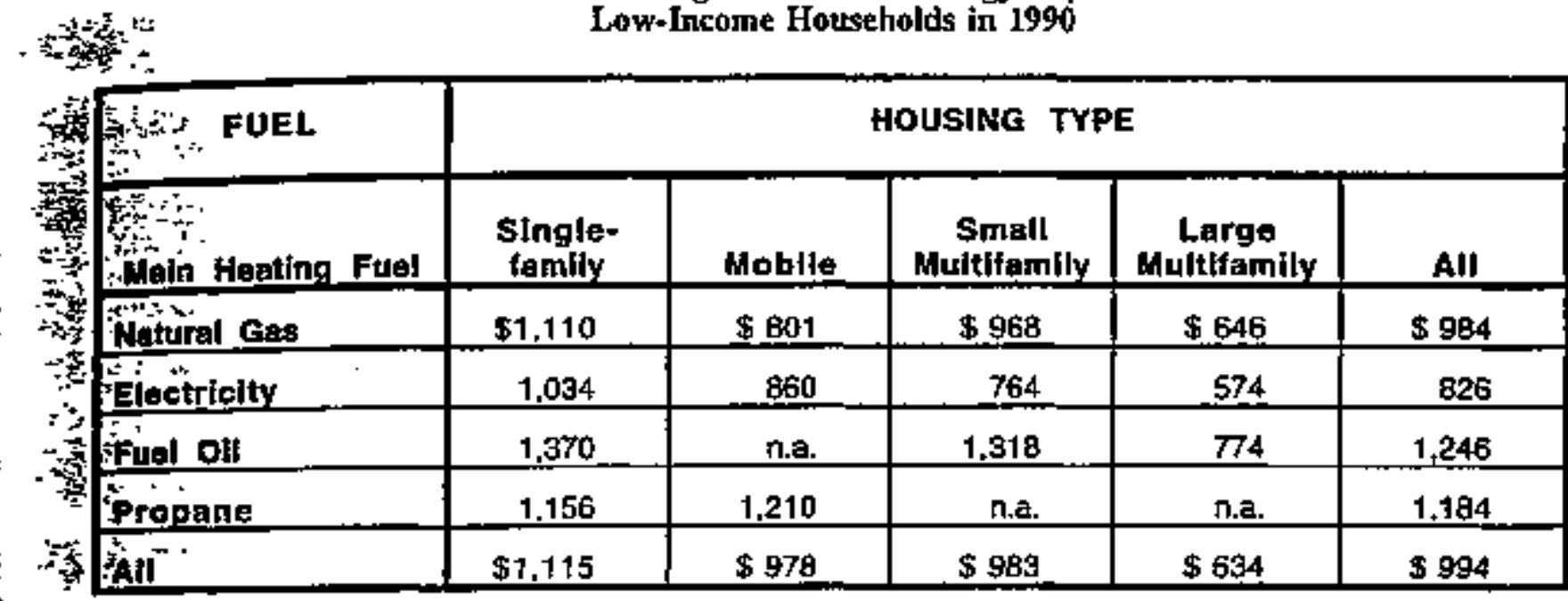

:- Expenditures by region for low-income households varied in a pattern that was roughly istonsistent with temperature-driven energy consuraption. Expenditures in the Northeast averaged \$1,201 and in the Midwest they averaged $\$ 1,094$. The higher costs in the Northeast, despite lower

- iverage fuel consumption, reflects the relatively higher use of somewhat less expensive natural gas in the Midwest and higher reliance on more expensive fuel oil in the Northeast. Expenditures in the - South averaged $\$ 958$ and in the West they averaged on $\$ 756$. This difference reflects not only tower Finaverage consumption in the West but lower energy prices as well.

$: \quad=$

\section{3 , INCOME}

The average income of bouseholds eligible for LIHEAP based on RECS data was $\$ 10,048$ in $\therefore$ 1990. This compared to an average income for all households in 1990 of $\$ 33,486$. Incomes for households heating with natural gas and fuel oil, which together comprised $63.9 \%$ of all eligible households, were close to this average at $\$ 10,162$ per year and $\$ 10,234$, respectively. Households using electricity, kerosene and propane had average incomes $\$ 700$ to $\$ 850$ below the mean.

As one might expect, households that owned their own homes had average incomes substantially higher than those that rented their homes. Average owner incorne for eligible thousenolds was $\$ 10,989$ compared to $\$ 9,095$ for renters. There was relatively litte disparity between Households that rented single-family homes and those that owned them. The major gap among incomes of the poor relative to housing type and lenure can be seen between owners and those who atrented mobile homes or units in large multifamily buildings. Renters in large buildings had incomes 
that averaged only $\$ 7,978$ and those that rented mobile homes had incomes that averaged $\$ 7,199$. nearty $\$ 3,000$ less than the average for all low-income households.

It is interesting to note that $70 \%$ of the 2.3 millian residents in mobile homes owned their own homes and had incomes slightly above the average for all the poor. The large income gap pertains to the 675 thousand mobile home renters. For details of income by housing type and tenure please see Appendix A, Table A-2l.

There was some difference in average income apparent when these data were calculated based on regional location. Low-income households in the West had the highest average incomes at $\$ 1$ 1,324 and those in the South had the lowest at \$9,209. Low-income households in the Northeast had an average income of $\$ 10,622$ and those in the Midwest averaged $\$ 9,781$. These pattens generally were consistent with regional variations in living costs.

\subsection{RESIDENTIAL ENERGY BURDEN}

"Energy Burden" is a statistic intended to reflect the actual inpact of residential energy costs on household butgets. It is calculated by dividing average residential energy expenditures by average income to express expenditures as a percentage of income. In many respects it is the key measure of the itripact of energy costs on low-income households because it provides a measure, not only of energy costs. but of affordatility as well.

There are two principal ways in which energy burden can be-calculated for a given group of flouseholds. One of these calculates energy burden for each household in a sample and then derives an average for these individual calculations_ that is to say the average of the individual burdens. The second method calculares average energy expenditures for all households in the group and divides this by the average of all income for the group; in cxher words, the group burden.

These two methods yield remarkably different results, each of which says something important about the impact of energy expenditures on low-income budgets. By the first method, the average of the individual burdens, the mean energy burden for low-income households in 1990 was $14.4 \%$ of income and for all U.S. households it was $6.8 \%$. The median low-income housetold burden was $10 \%$. By the second method, the group burden, the mean energy burden for low-income househoids was $10.1 \%$ of income and for all U.S. households it was 3.55 .

In large measure the difference can be explained by the fact that a substantial minority of low-income households has energy expenditures that far exceed the low-income average and/or have incomes that are substantially below the average. These houstholds are better represented by the byrden when caiculated as an average of individual housthold burdens, or $14.4 \%$ of income, because this method weights each individsal household equally. Another advantage to this way of measuring energy burden is that it ireats burden as an individual household statistic and permits one to distinguish among subgroups of houscholds based on theit individual energy burdens. 
The second method, the group burden, tends to better reflect the central tendency of the whole group that is being reasured. That is to say, it comes closer to representing the energy burden for those households that are in the middie of the group as defined by a numerieally balanced distribution of the households around the median of $10 \%$. This measure has the added advantage of allowing one to more easily measure the amount of money needed to redress imbalances between energy burdens aniong different classes of consumers.

In this report, which places greater emphasis on the comparison of energy burden among households, the mote frequently used statistic is the average of the burdens, that is to sty, the first method. In most cases this witl provide the reader with the sharpest contrast between the groups being described and compared. In many cases the report will also provide statistics in its labtes on burden as measured by the ratio of the averages, the second method, so that the reader can get a balanced picture of the central tendency and overall distribution of energy burden for the populations being discussed. These statistics will be designated is group burden so as to allow them to be distingutished from the individual burden measures derived by the first method.

As previously noted there are significant differences in energy expendiures by housing type and tenure, fuel type, and region. There are also differences in tincomes by those characteristics though they tend to be less dramatic. When these characteristics are combined to produce the burden statistics they generate a broad range of results reflecting the diversity of residential energy impacts on low-income budgets.

.

\subsubsection{Low-Income Burdens by Fuel Type}

Househoids heating with regulated fuels, both natural gas and electricity, had lower average energy burdens than those heating with "bulk" fuels like fuel oil, kerosene, and propane. Lowincome households heating with natural gas had an average burden of $13.9 \%$ in 1990 and those heating with electricity had an average burden of $13.1 \%$. By contrast. the households heating with fuel oil had a burden of $18.5 \%$ while those heating with propane had an average burden of $18.1 \%$.

There are a number of possible explanations for this disparity, not the least of which is the relatively high concentration of fuel oil households in the colder regions of the country, which tends to boost average expenditures. A second explanation is the concentration of propane tuel use in rural poptsiations where the incomes are lower than average for all law-income households. Both lower-than-average incomes and higher-than-average expenditures are therefore contributing factors. Please see Table 2.4 for details. 
Table 2.4 Income, Energy Expenditures and Energy Burden of Eligible Low-Income Households in 1990

\begin{tabular}{|c|c|c|c|c|c|}
\hline \multicolumn{2}{|c|}{ FUEL } & \multicolumn{4}{|c|}{ HOUSEHOLD } \\
\hline $\begin{array}{c}\text { Maln Heating } \\
\text { F uel }\end{array}$ & $\begin{array}{l}\text { Percentage } \\
\text { af All Types }\end{array}$ & Income & Expenditure & Burden & $\begin{array}{l}\text { Group } \\
\text { Gurden }\end{array}$ \\
\hline Natural Gas & $52.7 \%$ & $\$ 10,162$ & $\$ 994$ & $13.9 \%$ & $9.7 \%$ \\
\hline Electriclty & $20.0 \%$ & 9,368 & $B 26$ & $13.1 \%$ & $8.8 \%$ \\
\hline Fuel 여 & $11.2 \%$ & 10.234 & $\$ .246$ & $18.5 \%$ & $12.2 \%$ \\
\hline Propane & $7.6 \%$ & 9,275 & 1,184 & $18.1 \%$ & $12.8 \%$ \\
\hline Other & $6.0 \%$ & 11,449 & 874 & $9.6 \%$ & $7.6 \%$ \\
\hline All & $100,0 \%$ & $\$ 10,048$ & 5994 & $14.4 \%$ & $9.9 \%$ \\
\hline
\end{tabular}

- Does noe add to $100 \%$ due to the exclusion of a separate line for kerosene which tepresents a small number of households. Kerosene was ror included in the calculation of "other" but it was a component of the celculation of the overall average presented on the botiom line.

\subsubsection{Low-Income Burdens by Housing Type and Tenure}

Residents in large multifamily buildings had energy burdens similar to those in the other housing types, $13.3 \%$ compared to $14.2 \%$ for residents of single-family dwellings and $13.7 \%$ for residents of mobile homes. By contrast, the $14 \%$ of all low-income households living in small muttifamily buildings had an average energy burden of $17 \%$.

The busden for low-income residents of larger buitdings tends to be nearly the same as that of all low-jncome households because both incomes and expenditures were lower than those for the low-income population as a whote. In the case of residents of small multifamity butildings, the relatively high energy burdens result from a larger proportion having incomes well below the mean and energy expenditures that were near the average.

For each housing type the households that rented tend to have higher energy burdens than those that owned their own homes. Owners had an average butden of $13.7 \%$ and renters had an average burden of $15.2 \%$. Among Jow-incame residents of single-family homes the burden on renters was $1.1 \%$ higher than the average for owners and among occupants of smal] muitifamily dwellings the burden was $1.6 \%$ higher for renters. For residents of mobile homes the average burden was $17.9 \%$ for renters and $12 \%$ for owners.

As a general matter the higher esergy burdens of renter housebolds resslted from of lower incomes rather than higher energy expenditures. Residential energy expenditures for renter households averaged $\$ 854$ in 1990 as compared to $\$ 1,[3]$, for owners even though the average burden for the former was higher. This was because renter incomes were disproporionately low, 
_Faveraging $\$ 9,095$ compared to $\$ 10,989$ for owner househoids. This pattem held true regardless of - Fousing type and was particularly acute in the mobile home population in which renters had an $\because$ arerage income of $\$ 7,199$ whereas owners had an average income of $\$ 10,339$. Please see Appendix A. Table A-22 for further details.

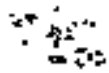

Low-Income Burdens by Regions

Low-income sesidents of the Northeast had the highest energy burdens at $17 \%$ of income and $\therefore$ those in the West the lowest, at $9.8 \%$. The low-income residents of the South and Midwest had s. average energy burdens of approximately $15 \%$.

The relatively low energy burdens in the West reflects both higher incomes in that region as well is $\rightarrow$ substantially lower energy expenditures. Households heating with natural gas in the West had an -javerage burden of $8.2 \%$, less than half that of fuel oil users in the Northeast, who faced an average borden of $20.2 \%$, and propane users in the Midwest, who bad an average burden of $18.1 \%$. For "' detzils please see Figure 2,2.

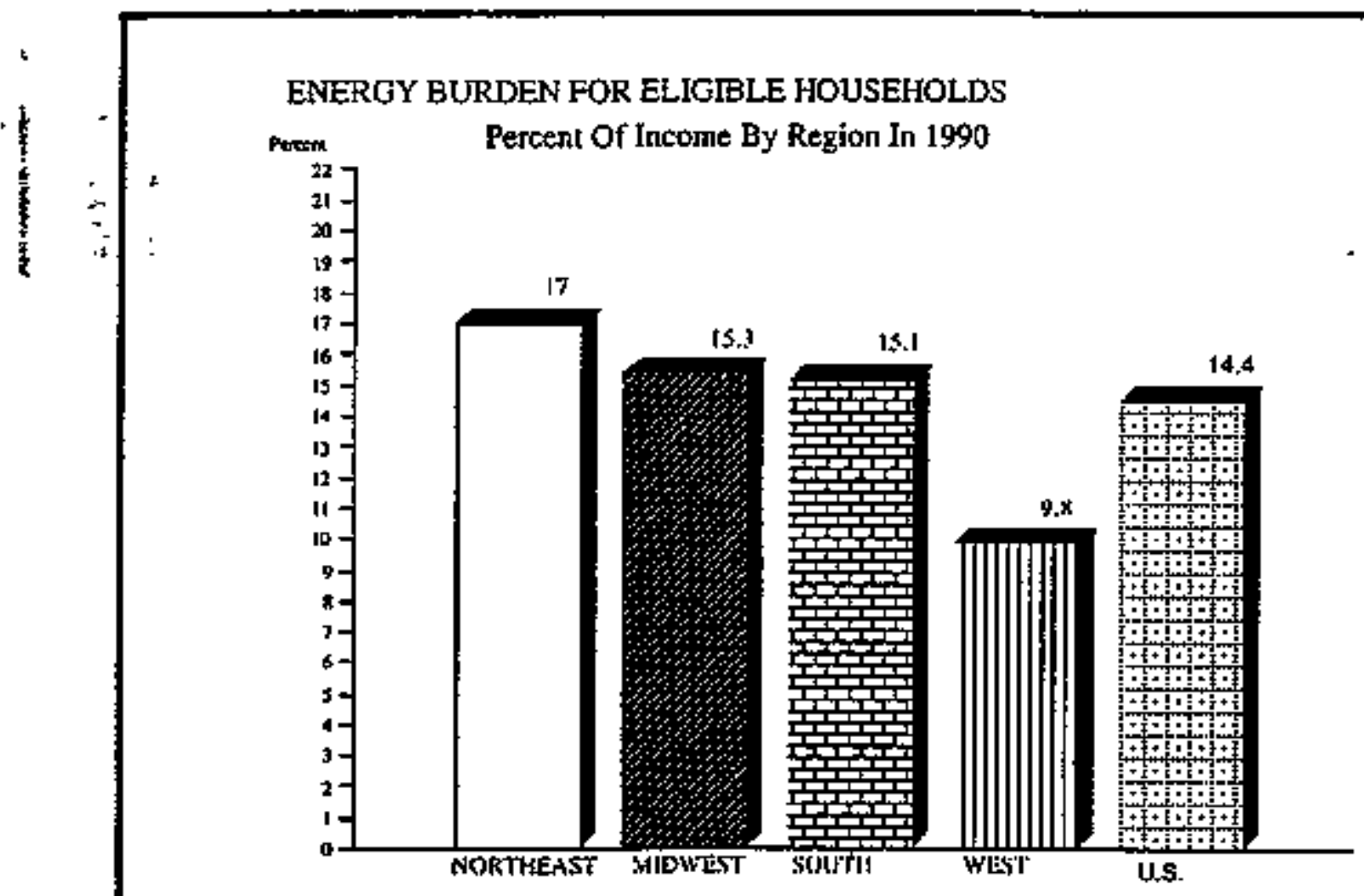




\subsection{DEMOGRAPHICS OF THE ELIGIBLE POPULATION}

\subsubsection{Elderly}

Among all low-income households, 12.2 million (43.7\%) had at least one person classitiod as elderiy, that is say, over the age of 60 . Of these, $70 \%$ owned their own homes and an additional $8 \%$ rented single-family homes. There were only 1.6 million households with elderly persons who rented in mutifamily dwellings. Please see Table 2.5 for further details of major characteristics of lowincome households by dernograptic group.

Table 2.5 Characteristics of the Eligible Households in 1990

\begin{tabular}{|c|c|c|c|c|}
\hline & $\begin{array}{l}\text { Percent of } \\
\text { Elfglbles }\end{array}$ & $\begin{array}{l}\text { Percent } \\
\text { Renters } \\
\end{array}$ & $\begin{array}{c}\text { Aversge } \\
\text { Expenditure }\end{array}$ & $\begin{array}{l}\text { Average } \\
\text { Burden }\end{array}$ \\
\hline Eiderly & $43.7 \%$ & $29.6 \%$ & $\$ 994$ & $14.0 \%$ \\
\hline With Chlldren & $42.9 \%$ & $60.9 \%$ & 1,116 & $14.0 \%$ \\
\hline Slngle Parent & $19.9 \%$ & $67.5 \%$ & 1,068 & $18.0 \%$ \\
\hline African Americen & $16.5 \%$ & $66.1 \%$ & 1,0a9 & $19.0 \%$ \\
\hline AFDC & $11.9 \%$ & $80.9 \%$ & 1,013 & $22.0 \%$ \\
\hline sst & $6.4 \%$ & $55.4 \%$ & B31 & $16.0 \%$ \\
\hline LIHEAP & $13.7 \%$ & $52.9 \%$ & 1,000 & $19.0 \%$ \\
\hline Fogd Stampa & $20.0 \%$ & $72.5 \%$ & 964 & $20.9 \%$ \\
\hline All Elliglble Households & $100.0 \%$ & $49.7 \%$ & $\$ 994$ & $14.4 \%$ \\
\hline
\end{tabular}

The average energy expenditure for households with elderiy persons was $\$ 984$ in 1990 , essentially the same at that of the low-income population as a whole. In ardition their energy barden was $14.0 \%$, also near the average for all low-income households. Among the elderiy, those renting in large multifamily dwellings had a substantially lower energy burden than their non-renting counterparts, at only $9 \%$ of income. The 580 thousand living in mobile homes, both renters and owners, also had a lower energy burden than the average, at $11.0 \%$ of income.

\subsubsection{Children}

Approximately 12 mitlion (or 42.9\%) of the low-income housetolds, were households with children. This compares with $37.0 \%$ of all U.S. households in 1990 that had at least one person under the age of 18 related to the householder. These fouseholds, in stack contrast to those with elderly residents, were much more likely to ment their homes than to own them. Only $39.1 \%$ of households with children owned their dwellings and $27 \%$ were renters in single-family homes. Approximately $10.5 \%$ lived in mobile homes and $15.4 \%$ lived in large multifamily buildings. 
Housełolds with children had significantiy higher mean energy expenditures than did the

s. low-income population as a whole. \$1, J16 compared to \$994. Households with chitdren that owned

$\because$ their own homes had average expenditures of $\$ 1,291,30 \%$ higher than the low-income mean, and the 812 thousand who owned theic own mobile homes had average expenditures of $\$ I_{+} 300$. $\therefore$ low-income households at $\$ 4.0 \%$. Among households with chitdren the highest energy busdens were found among the 1.8 million househoids Jiving in small muttifamily dwellings, at $20.0 \%$ of income. . And among renters of mobile homes, at $18.0 \%$ of income.

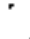

\subsubsection{Single-Parent Households}

These households comprise a unique suoset of the low-income households with children and $\therefore$ - $19.9 \%$ of she total eligible population. As one might expect, these housefolds tended to rent dwellings, with $67.5 \%$ renting and $32.5 \%$ owning their homes. Approximately 2.8 million, or $50.2 \%$ were living in single-family homes and $20.7 \%$ were living in sntall multifarrily dwellings.

Among the single-parent population, mean energy expenditures were close to the norm for all the poor at $\$ 982$ in 1990 . Those living in their own single-family homes had average expenditures of $\$ 1,2 \$ 7$ per year and those in owned mobile homes averaged $\$ 1,224$ for the year.

The overall energy burden for the single-parent househoids was higher than the average for all low-income househoids at $18.0 \%$ of income. This can be attributed, in part, to higher than average energy expenditures among those houseftolds living in rental dweltings. Their expenditures averaged $\$ 982$ and their energy burden averaged $20.0 \%$. This compares to averages of $\$ 854$ and $15.0 \%$ of income for all low-income renter households. Among the $1 . t$ mitlion restitents of small

290. multifanity dwellings the burden in 1990 was $22.0 \%$ of income.

den

\subsubsection{Exturicity}

African American households comprised $18.5 \%$ of all low-jncome houseboids in the RECS saruple and hispanics $10.1 \%$. This compares to $11.3 \%$ and $6.6 \%$ respectively among all households. Approximately $66 \%$ of both groups rented their homes as compared to $49.7 \%$ of all low-income households. Roughly $20 \%$ of African Americans and $25.8 \%$ of Hisparics rented single-family homes.

rith

rson

with

3 of

mes.

Despite these similarities the average energy burdens of the two groups are stibstantially different. The average for Hispanics in 1990 was 13.0\%, just below the average for all low-income households. The average energy butden for African Americans was 19.0\%, well above the lowincome mean. The major explanacion for this appears to be a geographic one. Approximately 43.0\% of eligible Hispanic households are located in the West where average residential energy costs tend to be lower than they are in the rest of the country. By contrast, only $10.5 \%$ of eligible African $\therefore$. 
American households were located in the West. For further details concerning the demographic and energy characteristics of the tow-income population please see Appendix A, Table A-29.

\subsection{PROGRAM PARTICIPATION}

Among eligible households, an estimated 3.3 million (1 $1.9 \%$ ) participated in the Aid To Families With Dependent Children (AFDC) Program, 2.336 million ( 8.4\%) were recipients of Stpplemental Security Income (SSI), and 5.586 miltion, (20\%) were Food Stamp recipients. An estimated 3.824 million, $13.7 \%$ of all households eligible, reported receiving heating assistance (LIHEAP).

These estimates from RECS as well as participation estimates from other surveys such the CPS and Survey of Income and Program Participation made for the Department of Heath and Human Services. tend to understate program participation when compared to other sources. such as the offices that administer the programs themselves. For example, approximately 8.3 million households received Food Stamps in 1990 and 5.8 militon received LIHEAP according to statistics provided by the Committee on Ways and Means of the U.S. House of Representatives based on information from the Department of Health and Human Services. The undercount of program participation has been persistent through the household surveys for many years. For purposes of calculating rates of program participation, sources other than RECS are superior. The statistics presented below nonetheless are the bast available regarding energy costs and burdens for these populations.

\subsection{AFDC}

Participants in the AFDC Program, often described as the "welfare poor" because AFDC is the feceral govemment's major general income mainterance program, tend to rent rather than own their homes. In 1990 an estimated $80.9 \%$ were renters. Among the renters, occupancy was split almost evenjy among single-family units at $27.3 \%$, smalt multifarnily units at $24.7 \%$, and large multifamily tnits at $23.5 \%$.

Average energy expenditures for all AFDC households were $\$ 1,013$ in 1990 , very close to the nom for all low-income households. Those fiving in and owning single-family homes had average expenditures of $\$ 1,239$, higher by $\$ 100$ than the average for other low-income households with similar housing type and tenure. The average expenditure for AFDC renters in large multifamily buildings was $\$ 723$, higher than the $\$ 633$ average for the general low-income population who were similarly situaced.

The average energy burden for AFDC houstholds was higher than the average for all eligible households at $22 \%$ of income in 1990 . This reflects comparable energy expenditures and significantly lower average incornes. Households that owned their own homes had a mean burden of 18\% as did those who rented in large mulzifamily buitdings. Renters in small multifamily bujldings 


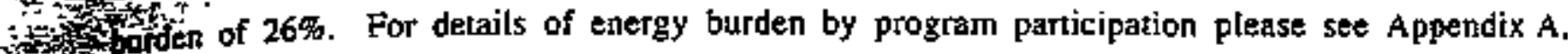

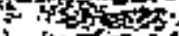

ins

tits.

$=3$

SWI

Supplemental Sectrity Income (SSI) is a social security program that provides income to the in fidional $14.2 \%$ rented single-family homes. Approximately $9.7 \%$ of SSI households lived in

然

: 算 for all low-income households. Expenditures by renters averaged $\$ 722$ compared to $\$ 854$ for all

势

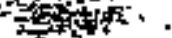

siowaters.

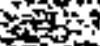

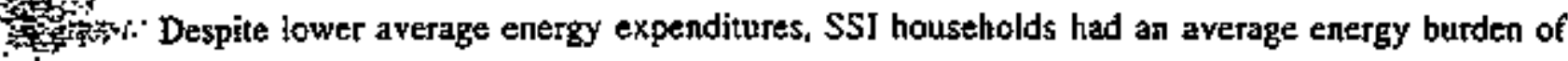
$-16 \%$ in 1990 reflecting Iower average incomes than the eligible population as a whole.

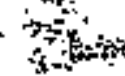

2.6 .3 LIHEAP

. Among households receiving LIHEAP assistance, $53.0 \%$ wete renters, which is roughly Fit comparable to those for all low-income households. Approximately $12.5 \%$ lived in mobile homes ind $24.6 \%$ rented in single+family homes. An estimated $12.0 \%$ lived in rented small multifamily

$\because$ prits and $12.5 \%$ rented in large buitdings, below the low-income average of $18.5 \%$ for renters in - Jarge multifamily buildings.

Energy expenditures by LIHEAP recipients averaged $\$ 1000$ in 1990 , approximately the same as the average for all low-income households. Expenditures by renters averaged $\$ 1003$, well above

$2 . i^{*}$ average for the same tenure group among all low-income households. By contrast those who owed their own singie-family homes had average expenditures of $\$ 963$, well below the average of $\$ 1,139$ for similarly situated households in the general low-jncome population.

LIHEAP recipients had an average energy burden higher than that of all low-income households at $19.0 \%$ of income. The burden was $21.0 \%$ among renters and $12 \%$ for owners. Renters of single-family and mobite homes had particularly high-burdens of $23.0 \%$. Those in large multifamily buildings also had a high average burden of $20.0 \%$ of income.

$\because$

2.6 .4 Food Stamps

$\because \quad$ Food Stamp tecipients were much more likely to rent thejr homes than the low-income :population as a whole. An estimated $72.5 \%$ were renters. Of these the largest proportion, $28.1 \%$ of $=$ 
the total, rented single-family homes, $22.8 \%$ lived in large buildings. $16.9 \%$ were in small muleifamtly buildings and $4.7 \%$ were in mobile homes.

The average energy expendituse for food stamp secipients was $\$ 964$ in 1990 , near the average for all low-income bouseholds. The average renter expenditure was $\$ 924$, higher than the average for all the poor of $\$ 854$ and teflecting the high proportion of renters of single-family homes. Residents in mobile homes also had a high average expenditure at $\$ 1,065$. compared to $\$ 978$ for all low-income residents of nobile homes.

The average energy burden for food stamp recipients was $20.0 \%$ of income in 1990, well above the $14.4 \%$ average for all the poor. Renters had an average energy burden of $21.0 \%$ and those in smalt multifamily butldings wete particularly hard hit at $24.0 \%$ of income. Renters in singlefamily homes also had a high-burden of $22.0 \%$. Mobile home residents had an average burden of $19.0 \%$.

Households participating in public assistance programs tended to have higher burden levels than low-income households in general, seflecting a tendency to lower incomes, nat higher energy bilts. This conciusion applies to all four public assistance programs examined. 


\section{PROFILE OF THE "HIGH-EXPENDITURE" HOUSEHOLDS}

然:

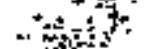

According to the results presented is "The \$cope of the Weatierization Assistance Program: The Weatherization Population and The Resource Base“ (Meg Power et. a1.). 3.9 million households recived weatherization services from DOE, utility, or other sources, from Program Year 1978 Fin Sictices is therefore quite substantial, particularly when considered in light of the number of

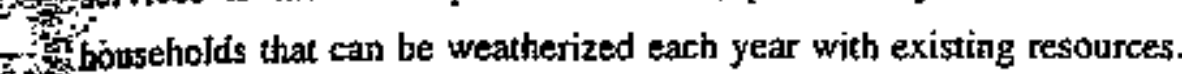

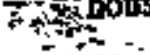

In order to identify a population within the larger low-income base that might best be iy 7.

typopulation based on two criteria -- high energy expenditure and high energy bunden.

ty 4expenditures, measured in expenditures per square foot per heating degree day, were one standard Ideviation or more above the mean for all households in their climate zone and Census Division. "High-burden" households were those with residential energy burdens, measured as residential - Sheating expenditures divided by income, that were one standard deviation or more above the mean for all low-income households in their climate zone and Census Division. Five climate zones based Fon heating degree days were applted across the nine Census Divisions. For maps delineating Census 镂

This chapter describes the high-expenditure households and their characteristics. Chapter 4 idescribes the high-burden population.

? The use of heating expenditures weighted by heating degsee days per urit of living space to ${ }_{s}$ define a potential weatherization target population has several feawres to recommend it. First, it takes ... into account the energy efficiency of the dwelting weighted by fuel cost and measures it against sissimilarly situated households. Since the weatherization progran seeks to improve the energy efficiency of low-income dwellings as one of its major objectives the least efficient of those homes in each area are one of the logical target populations.

Second, energy expenditures per heating degree day per square foot is a measure used in

" Sorne states to prioritized weatherization candidates or to help defermine the appropriate level of efficiency investment. It therefore has some acceptance within the weatherization community as a targeting concept.

$\therefore \quad$ Finally, there are a host of seasons why any individual housing unit may be energy . inefficient. It would be unrealistic to expect that any general survey would be able to capture these characteristics. The measure used to defme high-expenditure households conveys a picture of the $\because$ least efficient low-income housing stock around the country without engaging in the nearly is. impossible task of defining that housing stock by the characteristics that make it ineficient.

$\therefore=$ 
One isste of major concem in defining this set of housebolds was the use of expenditures rather than Btus to define consumption. The advantage of the expenditure approach is that it translates ali consumption into a uniform measure that reflects both its energy value, that is volume of Btus consumed, but also its economic value to consumers. The risk with this measure is that it tends to tavor the selection of households using higher priced fuels rather thon those that consume the most. This posed the danger that large price differentials would badly skew the selection process causing an underestimate of houscholds using lower-priced fuels. particularly natural gas, that could benefit substantially from weatherization.

in practice, the use of regional and climate zones to define meastrement groups for the selection of the high-expenditure households tended also to neutralize interftuel price disparities. Natural gas in the Northeast, for example, does not enjoy the significant price advantage over fuel oil and propane that national average prices might saggest. The high-expenditure households measured in terms of expenditures therefore tended to reflect the same gentral hearing fuel penetsation patterns as did all low-income households in each region. There was no appacent fuel-type bias as further explained in the heating tuel section below.

\subsection{HIGH-EXPENDITURE HOUSEHOLDS: HOUSING CHARACTERISTICS}

An estimated 5.0 million households of the 27.9 mitlion low-income households in the 1990 RECS met the definition of high-expenditure households. Of these. $51.4 \%$ lived in single-family homes and $19.2 \%$ lived in mobjle homes. The percentage living in mobjle hornes was much higher than the $8.2 \%$ that did so among all low-income housefsolds. There were $19.2 \%$ living in small multifarnily butldings and $10.2 \%$ lived in large muitifamily dwellings. This compares to $19.1 \%$ and $14.1 \%$ for the respective housing types among all low-income fousefolds. .

High-expenditure households in the Northeast were much less likely to live in single-family dwellings; just $23.8 \%$ did so in 1990 . The proportion tiving in small multifamily dwellings was $36 \%$. more than twice proportion for alt the poor. In the Midwest, on the other hand, $45.7 \%$ of highexpenditure households lived in single-family homes and $21.7 \%$ lived in mobile homes.

In the South, high-expendjture households were characterized by very high residency rates in single-farily dwellings. An estimated $71.6 \%$ lived in single-family homes and $16.2 \%$ lived in mobjle homes. About lo\% were in smafl multifamily buildings. In the West $52.5 \%$ of high-expenditure households lived in single-family homes and mearly a quarter, $24.9 \%$ lived in mobile homes. The proportions in smail and large multifamily dweilings were $12.2 \%$ and $10.4 \%$, respectiveiy.

\section{I.1 High-Expendtture Households: Tenure}

Owners comprised $46.2 \%$ of the high-expenditure population, a percentage that was comparable to that for the general eligible population. Approximately two thitrds of the owners lived 
in single-family homes with $27.7 \%$ owning mobile homes. An estimated $7 \%$ owned thiteir own in small multifamily buildings.

. Among renters, who comprised $53.8 \%$ of atl high-expenditure housefolds, approximalely ; $39.0 \%$ rented single-family homes and $30.0 \%$ lived in small multifamily dwellings. Approximately 18.9\% of renters lived in large multifamily buildings while $12.0 \%$ rented mobile homes. The proportion living in small multifamily dwellings and mobile homes was higher than that of the overall Fow-income population while the percentage in large buildings was only about half the proportion for ival the poor. Please see Figure 3.J for details of housing and tenure characteristics.

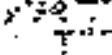

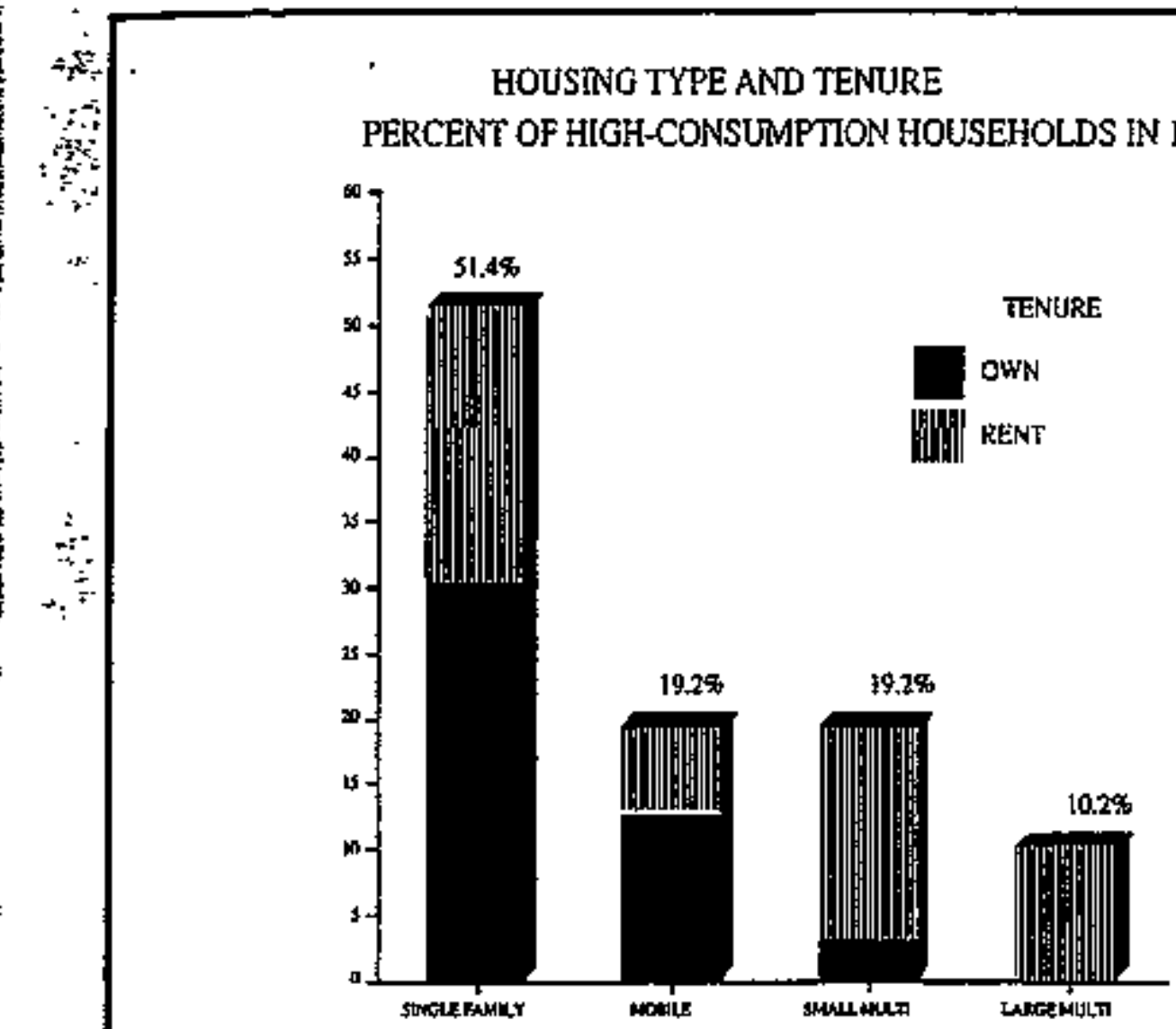

Figure 3.1 Housing Type and Tenure for High-Expenditure Households

\subsubsection{High-Expenditure Householdis: Heating Fuel}

;- The proportions of heating fuel use by type for high-expenditure households tends to be consistent with that of the general low-income population. Natural gas was the dominant primary heating fuel with $47.2 \%$ of all households. followed by $18.7 \%$ for electricity and $11.3 \%$ for fuel oil.

$1 \quad y^{2}$ 
The most striking figure was the proportion of high-expenditure households using propane. 17.4\% of the subpopulation. This figure is far higher than the proportion among all low-income households and is consistent with the dispropontionate representation of mobile homes within the high-expenditure poputation.

The pattem of regional fued use variability that characterized the general low-income population also is present among high-expenditure households. In the Northeast, $32.8 \%$ of highexpenditure households heated with fuel oil, $7.8 \%$ used kerosene and only $3.9 \%$ heated with propane. In the Midwest, natural gas predominated as the heating fuel for $54.3 \%$ of high-expenditure households but propane was the second most common fuel with $23 \%$ of high-expenditure households. Fuel oil and electricity followed with about 10\% each of the high-expenditure househoids in the region.

In the South nitural gas was the most frequently used home henting fuel, employed by $40.9 \%$ of the high-expenditure households. Propane was once again the second most frequently used heating fuel with $22.9 \%$ of households heating with it followed by electricity at $\mathbf{3 8 . 6 \%}$. In the West, by consast, while naural gas predominated with $51.6 \%$ of high-expenditure households, electricity was used for heat by $36.1 \%$. As estimated $12.3 \%$ used propane.

\subsection{HKGH-EXPENDITURE HOUSEHOLDS: ENERGY EXPENDTTURES}

The mean energy expenditure for high-expenditure households was $\$ 1,233$ in 1990 , which was substantially higher than the average for all low-income households of $\$ 994$. The average expenditure varied substantially by fuel type. Households heating with nanual gas and electricity had average expenditures of $\$ 1,155$ and $\$ 1,073$ respectively. Those high-expenditure households using home fuel oil, on the other hand had average expenditures of $\$ 1,567$. High-expenditure propane users who heated with that fuel had average expenditures of $\$ 1,343$. Please see Table 3.1 and Appendix A, Tables B-[ I, B-12 and B-13 for details of income, expenditures, and burdens for highexpenditure households.

Among househotds in the high-expenditure sample there was substantial variation in household expenditure in 1990 . The standard deviation for expenditures was 5537 . This high level of variability characterizes households across abj fued types. 
Table 3.1 Income, Energy Expenditures and Energy Burden
on High-Expenditure Households in 1900

$\therefore 2:$

\begin{tabular}{|c|c|c|c|c|c|}
\hline \multicolumn{2}{|c|}{ FUEL } & \multicolumn{4}{|c|}{ HOUSEHOLD } \\
\hline $\begin{array}{c}\text { Maln Hesting } \\
\text { Fuel } \\
\end{array}$ & $\begin{array}{l}\text { Percentage } \\
\text { of Al! Types }\end{array}$ & Incolme & Expenditure & Burden & $\begin{array}{l}\text { Group } \\
\text { Burden }\end{array}$ \\
\hline Natural Gas & $47.2 \%$ & $\$ 9,301$ & $\$ 1,155$ & $17.0 \%$ & $12.4 \%$ \\
\hline Eloctrielty & $18.7 \%$ & 7,863 & 1,073 & $21.0 \%$ & $13.6 \%$ \\
\hline :Fuel oll & $11.3 \%$ & 10,235 & 1,567 & $27.3 \%$ & $15.9 \%$ \\
\hline Propane & $17.4 \%$ & 9.917 & 1,343 & $16.5 \%$ & $13.7 \%$ \\
\hline Dother & $5.4 \%$ & 9,028 & 1,477 & $24.4 \%$ & $22.5 \%$ \\
\hline All & $100.0 \%$ & $\$ 9,254$ & $\$ 1,233$ & $19.2 \%$ & $13.3 \%$ \\
\hline
\end{tabular}

$\vec{n}$

\subsection{HIGH-EXPENDITURE HOUSEHOLDS: INCOME}

* The average mean income of high-expenditure househoids was less than the average for all *- low-income househotós, $\$ 9,254$ in 1990 compared to $\$ 10,048$ for all low-income households. This saried substantially by fuel type. High-expenditure housebolds heating with natural gas had an

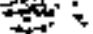

- 3 yerage income of $\$ 9,301$ in 1990 and those using propane for heat had an average jncome of $\$ 9,817$. Fuel oil users, on the other hand had an average income of $\$ 10,235$, well above the mean for

al] high cotsuming households. Households heating with eicctricity had income well below that mean at an average of $\$ 7,863$.

:*: = - There was remarkably little disparity in incomes based on tenure. High-expenditure z. bouseholds that owned their own homes had an average income of $\$ 9,324$ whereas renters had an $\overrightarrow{i t}$ average income of $\$ 9,195$. Renters in large multifamily buildings had an average income of $\$ 6,953$ and those renting mobile bomes averaged $\$ 7.325$, a pattern generally consistent with that for all lowin: incone households.

\subsection{HGH-EXPENDITURE HOUSEHOLDS: ENERGY BURDEN}

$\because \quad$ Energy burden, the measure of the combination of energy costs and household jncone, reflects the beavy burden imposed by above-average fuel consumption on these households. The mean energy burden for high-expenditure households in 1990 was $19.2 \%$, substantially higher than 登: ithe $14.4 \%$ average for all low-income honseholds.

The energy burden of high-expenditure households shows substantial variation by fuel zype. Fuel oil users had by far the highest average barden among the major heating fuel types at $27.3 \%$ of $\therefore$ jacome. This compares to $21 \%$ for electricity and $17 \%$ for households heating with natural gas. The 然努 
average energy burden for high-expenditure propane users in 1990 was 16.5\%. These burden scatistics are all substantially higher than the comparable averages for all low-income households by fuel type with the exception of propare.

In contrast with the general low-income population, where the avenge burden for renters in large mtritifamily buildings was somewhat lower than the average for all households, arang highexpenditure households these renters faced a bigh $22.3 \%$ burden in 1990 . This results from the fact that average expenditures for these househoids were $35 \%$ higher than for similarty situated senters in the general low-income population and the average income was $14.6 \%$ lower.

Residents of single-family homes, both tenters and owners, had burdens between 18.0 and $19.0 \%$ of income while mobile home owners had a burden of $15.7 \%$. Renters of mobite homes, on the other hand, had an average burden of $20.3 \%$ and those renting in small multifamily buildings had an average burden of $20.4 \%$. This is consistent with the general pattern of higher energy burdens for renter households than for owner households in similar housing types.

High-expenditure households in the Northeast have the highest average burden al $23.4 \%$ of income and those in the West had the lowest at $16.5 \%$ of income. Housetioids in the South and Midwest had average burdens of $18.6 \%$ and $19 \%$ respectively. The burden figure for highexpenditure households in the West, though lower than the ayerage in other regions, is substantially higher than the burden faced by alt tow-incorne households in the region, which was $9.8 \%$.

\subsection{DEMOGRAPHICS OF THE HIGH-EXPENDITURE HOUSEHOLDS}

\subsubsection{Elderly}

The proportion of low-inconte hotseholds with at least one person over the age of 60 among low-income high-expenditure households was $44.5 \%, 2.2$ million households, about the same as the proportion for the low-income population as a whole. Housing tenure and type for high-expenditure households with elderly residents was rotghly the same as that for similar households in the genemal low-income population. The energy expenditures for high-expendityre hotseholds with elderly residents was $\$ 1,146$ and the average burden was $17.0 \%$, somewhat below the $19.0 \%$ average for al] high-expenditure househoids.

\subsubsection{Children}

About 2 million households in the high-expenditure category, $42.0 \%$ of the total, were houscholds with children. These had housing and tenure characteristics comparable to those of similar households in the general low-incone population. Approximately a third of the highexpenditure households with children ljved in rented single-family homes and about is.0\% lived in mobile homes. 
Mean energy expenditures for these households averaged $\$ 1,403$ in 1990 compared to $\$ 1,233$ for all high-expenditure households. Particularly high expenditures were reported for households in their own mobile homes at $\$ 1,569$ for the year. The average energy burden for househoids with children in the high-expenditure cutegory was approximately $20.0 \%$.

\section{㙁点: 3.6.3 Single.Parent Fouseholds}

These households numbered I million, with about $75.0 \%$ of these renting and $25.0 \%$ owning - their homes. Approximately $50.0 \%$ were biving in single-family homes, $20.0 \%$ in small murtifamily $\because$ homes and $15.0 \%$ in mobile homes.

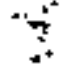

in.

零.

households but incomes were sonewhat lower. Renters had generally higher burdens than did

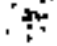
owners.

$\therefore$

\subsubsection{Ethnicity}

African-Americans comprised $27.3 \%$ of the high-expenditure class, a much higher = proportion than their representation in the general low-income population. Hispanics, on the other hand, were present in the same proportion as in the overalt low-income population. The energy Eurden averaged $20.0 \%$ for both groups. Please see Appendix A, Tables B-18, B-19, B 10 and B-21

\section{. 3.7 PROGRAM PARTICIPATION AMONG HIGH-EXPENDMUURE} HOUSEHOLDS

เุตร. Among high-expenditare households the rate of participation is basic public assistance :- programs was roughly comparable to that for the low-income population as a group. Approximately 14.4\% were AFDC recipients compared to $11.9 \%$ for all the poor. The proportions of SSI and LIHEAP recipients were 11.2 and $15.7 \%$ compared to 8.3 and $13.8 \%$ for the general low-income

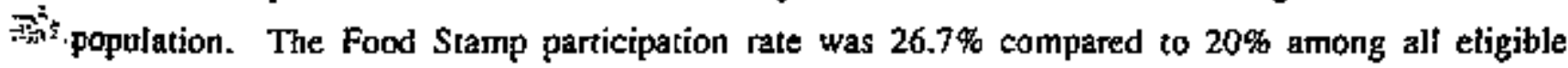
:households but, given the general tancertainties surrounding the participation rates in RECS, it would - be prudent not to assign too much significance to these difierences.

$=$. The residential energy expenditures of the population participating in public assistance programs in the high+expenditure group were consistently tigher than those for the equivalent groups in the general tow-income population. High-expenditure AFDC recipients averaged expenditures of $\$ 1,239$ in 1990 compared to $\$ 3,013$ for all AFDC households. SSI households in the high-expenditure class had an average expenditure of $\$ 1,013$ compared to $\$ 831$ for all SSI recipients. For LIHEAP recipients, high-expenditure households averaged $\$ 1,266$ in 1990 compared to $\$ 1000$ $x+\frac{1}{20}$ 
for all LIHEAP recipitents. Among food stamps hotseholds, high consumers averaged $\$ 1,216$ compared to $\$ 964$ for all Food Stamp recipienss.

Average energy burdens for higb-expenditure program particjpants were generally higher than those of their cossnterpasts in the general low-income population. In as such as the program participant population generally has a higher average energy burden than all qualified househoids, the high-expenditure porion of the population is particulariy hard hit by energy costs.

High-expenditure AFDC households faced an average energy burden of $27 \%$ in 1990. while LIHEAP recipients and Food Stamp recipients were each confronted by $25 \%$-of-income average burdens. This compared to $19 \%$ for the high-expenditure population as a whole and $14 \%$ for the total eligible population. High-expenditure households ljving in subsidized housing were something of an anomaly in this regard. Their energy burden was $17 \%$ of incorne compared to a burden of $19 \%$ of all eligible households living in subsidized housing. For detaits of the characteristics of the highexpenditure population participating in public assistance programs please see Appendix A. Tables BI] through B-17.

In summary, high-expenditure households were characterized by a relatively high proportion of mobjle-home residents when compared to all Jow-incone households as well as a significantly higher usage rate for propane. The average residential energy expenditure was $\$ 1,233$ in [990, well above the average for alt low-inconte households, whereas the average income of $\$ 9,254$ was below the low-income average. The average burden for this population was $19.2 \%$ of income, compared to 14.4\% for all low-income households. The proportion of high-expenditure households with an African-American menber was high relative to the tolal low-income population. There are otherwise no major disparities between high-expenditure households and alt low-income households in terms of program participation or other demographic characteristics. 


\section{HIGH-BURDEN AND HIGH-BURDEN/HIGH- EXPENDITURE HOUSEHOLDS}

Another means of determining who may be most in need of energy effrciency services

"ne

low-income housebolds is to focus on those who are most heavily burdened by residential E. The households described in this chapter sre those whose residential tivergy burden, measured as expenditures divided by income, was one standard deviation or more above the mean for ail households within their Census Division and climate zone.

然

Energy burden is a frequently used measure for evaluating the need for energy assistance and Weatherization services as well as for targeting those services within the low-income population. W Where high-expenditure households are most likely so reduce their energy consumption through Hitheatherization, high-butder households are perceived to be most in need of those services. To the test

wextent that these poputations overlap they provide a major target for weatherization services from a

.

This chapter first describes the high-burden population and then examines the characteristics

. of these households that fall into both high-burden and high-expenditure categories.

it

\subsection{HIGH-BURDEN HOUSEHOLDS: HOUSING CHARACTERISTICS}

High-burden households comprised 7.2 million of the 27.9 million hourseholds federally the fotal. A breakdown by housisig types and tenure is

shown in Figure $4 . \mathrm{t}$.

$\therefore \quad$ An estimated $56.2 \%$ of high-burden households lived in single-family houses and an additional $8.5 \%$ lived in mobile homes, proportions that are comparable to those for low-income

$=$ population as a whole. Approximately $19.1 \%$ tived in large multifamily baildings and $16.2 \%$ lived in :-small muttifamily structures.

In the South, approximately $60 \%$ of high-burden households lived in single-family homes and $9.2 \%$ lived in mobile hones with $21 \%$ living in large multifamily dwellings. In the Northeast, by $3 i^{-}$- contrast $38.2 \%$ lived in single-family dwellings, $30.8 \%$ lived in small mutifanity stnuctures, and only 4.7\% lived in mobile homes.

In the Midwest, $68.6 \%$ of high-buroien households lived in single-family homes atd only $5 \%$ : lived in targe multifamily dwellings. In the West, by contrast $23.8 \%$ of high-burden households lived in large multifamily structures, $13.2 \%$ lived is small multifamily buildings and $9.9 \%$ were in mobile homes.

势:

$+2$ 


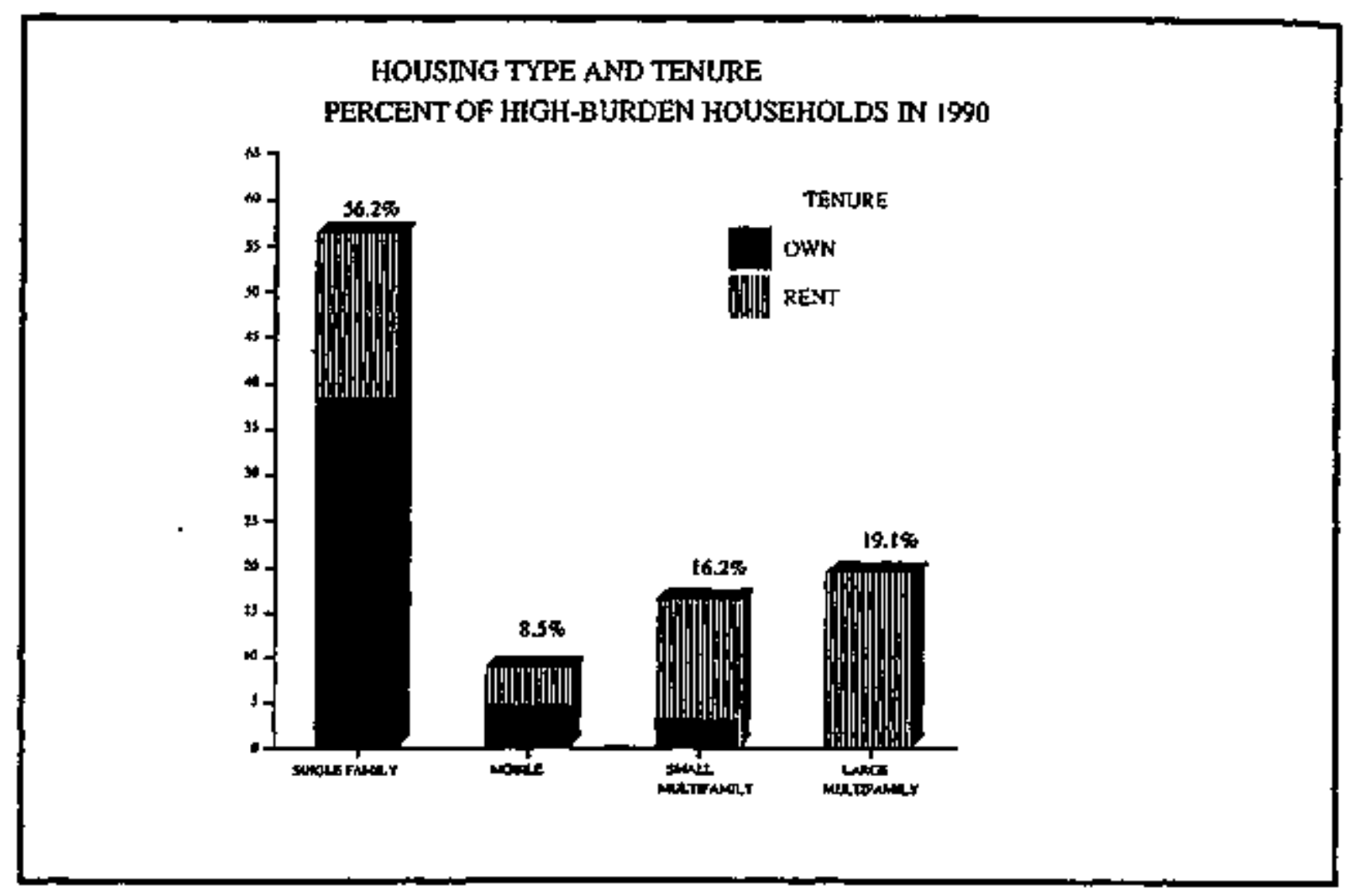

Figure 4.1 Housing Type and Tenure for High-Burden Households

Those national and regionas patterns were consistent with those found among afl low-income households.

\subsubsection{Tenure of High-Burden Households}

Hone ownership patterns were generally the same for high-burden households as they were for all low-inenme houstholds. Approximately $46.2 \%$ were owners compared to $50.3 \%$ of all lowincome households. Of the households that own their own komes, $82.7 \%$ were in single-family homes and $10.3 \%$ were in mobile homes.

Among renter houscholds, $35.5 \%$ of the total subgroup lived in large multifarnity buildings. 24.2\% were in small multifamily buildings, and $7 \%$ rented mobile homes.

On a regional basis tenure patterns were varied. About $35 \%$ of high-burden households in the Northeast were owners but in the Midwest the proportion of owners was $57.2 \%$. In the South $50 \%$ were owners and the West $37.3 \%$ owned their own homes. These statistics afe consistent with those for the larger low-income population. 


\subsubsection{High-Burden Households: Heating Fuel}

$\therefore$ Heating fuel patterns for high-burden households are largely the same as those for all low. $\therefore$ income households. An estimated $49.4 \%$ heated with natural gas, $17.3 \%$ used electricity, 15.6\% used fuel oil, $2.5 \%$ used kerosene, and $10.9 \%$ used propane.

Prevailing regional patterns of fuel use for all low-income households were present and even stronger among high-busden households. In the Northeast $49.5 \%$ of househoids used fuel oil and $241 \%$ heated with nattral gas. In the Midwest $60.4 \%$ of high-burden thouseholds used gas for heat and $16.6 \%$ used propane. A surprisingly high propontion heated with fuel oll- 14,0\% compared to . just $6.0 \%$ for all low-income households in the Midwest.

In: In the South, $14.7 \%$ of high-burden housetholds heated with propane, $25.2 \%$ employed "electricity, and $45.5 \%$ heating with gas. In the West $52.2 \%$ of higb-burden households used gas for

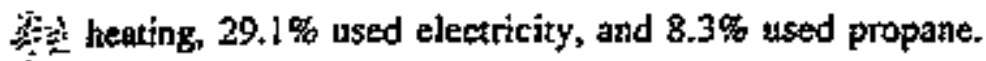

\subsection{ENERGY EXPENDITURES OF HIGH-BURDEN HOUSEHOLDS}

The mear residential energy expenditure for all high-burden households was \$1,175. significantly higher than the average for all low-income households and statistically comparabie to that for high-expenditure households, which was $\$ 1,233$ in 1990. Households in the high-burden

6. population that heat with natural gas and electricity had expenditures averaging $\$ 1.150$ and $\$ 954$ pespectively. For housetiolos with high-burdens using fued oil, expenditures averaged $\$ 1,422$ in 1990 and for those heating with propane the average was $\$ 1,324$.

$\therefore \quad$ The patern of high variability in expenditures even within climate zores and fuel types that was present for high-expenditure bouseholds was also found among high-burden households. For $\therefore$ details of expenditure, income, and burdens for high-burden households please sec Table 4.I.

\section{$\because 4.3$ INCOME OF HIGH-BURDEN HOUSEHOLDS}

$\therefore$

The single characteristic that most distinguishes high-burden households from low-income kn housefiolds in general is income. The average income of these households was only $\$ 5,419$ compared to $\$ 10,048$ for all low-income households in 1990 .

There was little substantial difference in incomes for households using different home heating * : fuels among all low-income households with one exception. The average income for high-burden households heating with gas was $\$ 5,598$ and for fuel oil heaters it was $\$ 5,865$. For housetolds

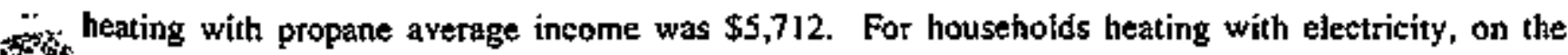
Tis other hand, income averaged only \$4,240. These differences are insignifican1, however, compared to the differences between any of those averages and those for alt U.S. househotds or even low-income households in general. 
T'abje 4.1 Income, Energy Expenditures and Energy Burden of High-Burden Households in 1990

\begin{tabular}{|l|r|r|r|r|r|}
\hline \multicolumn{2}{|c|}{ FUEL } & \multicolumn{4}{c|}{ HOUSEHOLD } \\
\hline $\begin{array}{c}\text { Main Heating } \\
\text { Fuel }\end{array}$ & $\begin{array}{c}\text { Percentage } \\
\text { of All }\end{array}$ & Income & Expenditure & Burden & $\begin{array}{c}\text { Group } \\
\text { Burden }\end{array}$ \\
\hline Natural Gas & $49.4 \%$ & $\$ 5.598$ & $\$ 1,150$ & $28.6 \%$ & $20.5 \%$ \\
\hline Electricity & $17.3 \%$ & 4,240 & 954 & $30.9 \%$ & $22.5 \%$ \\
\hline Fuel OII & $15.6 \%$ & 5,865 & 1,422 & $34.0 \%$ & $24.2 \%$ \\
\hline Propane & $10.9 \%$ & 5,712 & 1,324 & $30.5 \%$ & $23.2 \%$ \\
\hline Other & $5.9 \%$ & 4,475 & 1,077 & $31.6 \%$ & $19.0 \%$ \\
\hline All & $100.0 \%$ & $\$ 5.419$ & $\$ 1,175$ & $30.1 \%$ & $21.7 \%$ \\
\hline
\end{tabular}

" Does nol sum due to missing dala tor kerostnc.

There was some distinction between kigh-burden household when measured in terms of housing tenure and type. Households that owned their own homes had an average income of $\$ 6,447$ in 1990 and those renting their hornes had an average income of $\$ 4,538$. Renters in large muttifamily buildings, I.4 million households, had an average income of only $\$ 3,630$.

\subsection{ENERGY BURDEN OF HIGH-BURDEN HOUSEHOLDS}

The households in this category are those in each census division and climate zone whose energy burdens substantially exceed the norm. As one might expect, the energy burden figures for this group are starting. The average burden nationtwide was $30.1 \%$ compared to $14.4 \%$ for all lowincome households.

When measured in terms of primary heating fuel, high-burden households have a much lower tevel of variation between fuel types than do all low-income households. The average butden for households heating with gas was $28.8 \%$, for electricily $30.8 \%$, for fuel oil $34.0 \%$, and for propane $30.5 \%$. The differences between these averages is minor compared to the differences between any one of them and the averages for all low-income hotseholds.

The energy burden for renters averaged $33.1 \%$, and that for owners $26.7 \%$. Though average expenditures for owners were $\$ 342$ higher than for renters, the average income for the latter was $\$ 1,909$ below that of the former. Particularly hard hit in the renter popatation were 941 thousand housenolds living in small multifamily dwellings with an average energy burden of $37.4 \%$. Renters in single-family and mobile homes had average burdens of $32.7 \%$. Owners of single-farily homes had an average burden of $27.1 \%$ and owners of mobile homes had an average burden of $22.5 \%$. 
Those compare with average butdens of $13.8 \%$ for owners of single-farily homes in the entire low income population and $12 \%$ for owners of mobtle homes.

The large disparities in energy butdens by region that was previously noted in the lowincome population in general and among high-expenditure households persists in the high-burden sample. High-burden households in the West had an average burden of $20.8 \%$ of income in 1990. High as this was, it was significantiy lower than the average burden in the Northeast, which was $36.5 \%$. The average burdens in the Midwest was $33.0 \%$ and that in the South was $30.5 \%$.

\subsection{DEMOGRAPHICS OF THE HIGH-BURDEN POPULATION}

The elderty compromise $41.3 \%$ of the high-burden population and households with children were $39.9 \%$ of the total. These proportions are comparable to those for the low-income population as a whole.

The proportion of single-parent and African-American households was higher in the highburder population than among low-income housetholds in general. Approximately $25.9 \%$ of highburden househoids were single-parent households in 1990 compared to $19.9 \%$ of all low-income bouseholds. The same proportion or $25.9 \%$ of high-burden households was African American. This compares with $18.5 \%$ of all low-income households.

\subsection{PROGRAM PARTICIPATION AMONG HIGH-BUURDEN HOUSEHOLDS}

The substantially lower average income of high-burden households than that of all lowincome houstholds would generally qualify them for participation in public assistance programs at a higher rate than for the low-income population as a whole. This would appear to be born out by the statistics on participation rates.

Approximately $22.6 \%$ of these households were AFDC recipients compared to $11.9 \%$ of all the poor who received those benefits. An estimated $22.7 \%$ received LLHEAP benefits compared to $13.8 \%$ of all the poor. The Food Stamp participation rate was $33.3 \%$ compared to $20 \%$ for all the poor.

Energy burdens for highuburden AFDC and Food Stamp recipients both averaged $34 \%$ of

$\because \quad$ income in 1990. The burden for LIHEAP recipients averaged 31\% and that of S\$I recipients was 27\%. For further decails concerring the high-burden poputation please see Appendix $A$, Tables C-1 through C-21.

\subsection{HIGH-BURDEN/AIGH-EXPENDITURE HOUSEHOLDS}

Households that are both high-expenditure households and high-burden households are of particular interest to those concerned with targeting weatherization for maximum energy efficiency and equity benefits. These households were bath one standard deviation above the mean for heating 
expenditures per heating degree day per square foot and for the percentage of income devoted to home heating, a figure estimaced for each household based on an Energy Information Administration model of disaggregated residential fuel use.

An estimated 2.1 million households fitted into this tategory in 1990. These were $42.6 \%$ of alI high-expenditure households, and $29.3 \%$ of all high-burden households, and $7.6 \%$ of all lowincome households. At present rates of weatherizalion it would take four to five years to wentherize this number of househoids. The relntively small size of this sample imposes certnin limitations on the statistics that can be drawn from it, particularly for smaller ciements of interest such as regional housing characteristics or program participation rates.

\subsubsection{Housing Characteristics of High-Burden/High-Expenditure Households}

An estimated $51.4 \%$ of the high-expenditure/high-burden households lived in single-family homes with $19.3 \%$ living in small multitamily owellings and $17.5 \%$ in mobile homes. The percentage in large multifamily buildings was $11.8 \%$.

An estimated 323 thousand of these households were located in the Northeast, 628 thousand in the Midwest, 604 thousand in the South and 567 thousand in the West.

\subsubsection{Tenure of the High-Burden/High-Expenditure Households}

Approximately $46.9 \%$ of the high-burden/sigh-expenditure housetroids owned their homes which is a slightly lower percentage than for the low-income poptiation as a whole. Mobile home owners comprised $10.7 \%$ of the totat and owners of single-family homes comprised $30.2 \%$. An estimated $21.2 \%$ of the total rented single-family homes. The statistics for housing type and tenure are not significantly different than those for the larger low-income population.

\subsubsection{Heating Fuels of the High-Burden/High-Expenditure Households}

Natural gas was the single most widely used fuel for heating in this population, with $40.0 \%$ using it nationwide. Electricity was used for heating by $25.3 \%$ fuel oil by $13.1 \%$, and propane by 16.6\% - of the households. The proportion of households using propane was more than twice the proportion doing so among all low-income households. These tiguses ane consistent with those for the larger high-burden population.

\subsubsection{Energy Expenditures and Income of the High-Burden/High-Expenditure Households}

The average energy expenditure of the high-burden/high-expenditure households in 1990 was $\$ 1,339$, well above the average for all low-income households of $\$ 994$. Average expenditures ranged from $\$ 1,066$ for households heating with electricity to $\$ 1,566$ for those using fuei oil. 
- Heating systems fueled by naturai gas had average expenditures of $\$ 1,340$ and those heating with propane faced average expenditures of $\$ 1,500$.

Expenditures by owner househoids averaged $\$ 1,450$ and those of renters averaged $\$ 1,240$. This compares to an average expenditure of $\$ 1.131$ for alt low-income owners and $\$ 854$ for all lowincome renters.

Househotds in the high-burden/high-expenditure calegory had an average income of $\$ 6,114$ in 1990 compared to $\$ 10,048$ for all low-income households. Those households that owned their $\therefore$ own homes had an average income of $\$ 6,644$ while renter income averaged only $\$ 5,647$. The large $\therefore$ proportion of households renting single-family homes had an average income of $\$ 7,498$ while renters . in small mtttifamily dwetlings had an average income of $\$ 3,804$. Those in large multifamily $\therefore$ buildings had an average income of $\$ 4,869$. Please see Table 4.2 for details of income, energy expenditares and energy burden for high-buróen/high-expenditure households.

: $+2$

Table 4,2 Income, Energy Expenditures and Energy Burden High-Burden/High-Expenditure Households in 1990

$\cdots$

$-\Delta$

\begin{tabular}{|c|c|c|c|c|c|}
\hline $\begin{array}{l}\text { Main' Heating } \\
\text { Fuel }\end{array}$ & $\begin{array}{c}\text { Percentaga } \\
\text { of All }\end{array}$ & Income & Expenditure & Burden & $\begin{array}{l}\text { Growp } \\
\text { Burden }\end{array}$ \\
\hline Naturel Cag & $40.0 \%$ & $\$ 6,952$ & $\$ 1,340$ & $27.2 \%$ & $19.3 \%$ \\
\hline Electritelty & $25.3 \%$ & 4.914 & 1,066 & $29.6 \%$ & $21.7 \%$ \\
\hline Fued 애 & $13.1 \%$ & 5,417 & 1.566 & $43.7 \%$ & $28.6 \%$ \\
\hline Propane & $16.6 \%$ & 6,935 & 1,500 & $24.1 \%$ & $21.6 \%$ \\
\hline Al: & $100.0 \%$ & $\$ 6,114$ & $\$ 1,339$ & $30.4 \%$ & $29.9 \%$ \\
\hline
\end{tabular}

$\therefore$

$\therefore$ - Does not sum to $100 \%$ due to missing dau for kercoene and outhe minor fuels.

舟

$\therefore$

\subsubsection{Energy Burden: Högh-Burden/High-Expenditure Households}

The energy burden for those households averaged $30,4 \%$ of income, a figure comparable 10

$\because$

i: that for high-burden households and well above the average for high-expenditure householos, which

$\because$ was $19.2 \%$ in 1990 . The burcen for owners averaged $25.9 \%$ of income and that of renters was $34.4 \%$. The energy bunden for renters in small multifamily buildings was $39.2 \%$.

The average energy burden ranged from $24.1 \%$ for propane users to $43.7 \%$ for horse fuel oil users though the fisel oil sample is rather small. Those heating with natural gas had an average burden of $27,2 \%$ and for heaters with electricity the average energy burden was $29.6 \%$. 


\subsubsection{Demographics and Program Participation of High-Expenditure/High-Burden Households}

Households with the elderly comprised $40.4 \%$ of all high-expenditure/high-burder households and households with children were $38.6 \%$ of the cotat. Single parent households were $24.2 \%$ of the population and African Americans $29.7 \%$. These statistics are all consistent with those for the high-burden poptlation.

AFDC households comprised 22.1\% of the high-burden/high-expenditure households compared to $11.9 \%$ for all low-income households. LIHEAP recipients were $20.7 \%$ of the population compared to $13.8 \%$ among all the poor and Food Stamp recipients were $34.1 \%$ of the total. This compared to $20 \%$ Food Stamp recipiency rate among the general low-income population. SSI recipients were $12.6 \%$ of the households in the high-expenditure/high-burden population. These participation rates are also consistent with those of the high-burden population. For detailed statistics for the high-burden/high-expenditure households please see Appendix A. Tables D-1 through D-21. 


\section{OTHER POPULATIONS OF INTEREST}

The research team identified thtee other populations within the large set of low-income ds that could potentiaily provide additional insights into the best ways to target featherization assistance. One of these was the subset of households with housing characteristics that might indicate the need for weatherization, i.e. "low-efficiency" households. The second subset corisists of those households that were qualified for assistance in both 1987, the next most recent RECS survey, and in 1990 - "persistent-eligible" households. The third subset consisted of households weatherized in 1990 .

\section{LOW-EFFICXNCY HOUSEHOLDS}

Low-efficiency housenolds were defined as those households nationwide who reported little or no atic insulation as well as those households located in the Nortireasl and Midwest who rejorted having storm windows on less than $25 \%$ of their windows. The use of the additional measure of storm-window uilization in the two colder climate regions was intended to capture the fact that siorm windows were widely perceived to be cost-effective by balloing owners there. The survey questions concerming housing characteristics focus on stom doors. storta windows, and attic insulation and do not pennit a better definition of unweatherized housing, based on physical characteristics alone.

Of the 27.9 million households estimated to be eligible for weatherization in $1990,4.6$ million fitted the definition for this subset. Of these, $26.9 \%$ were located in the Northeast compared to 18.9 of all low-income housetiolds and $28.2 \%$ were in the Midwest compared to $23.1 \%$ of all lowincome households. Approximately $31.6 \%$ were in the South and $12.1 \%$ were in the West compared to $37.1 \%$ and $20.7 \%$, respectively, among all low-income households.

\subsection{Low-Efficiency Households: Tenure, and Fuel Use}

Low-efficiency households had generally similar tenure characteristics to the general eligible population. Owners comprised $53.3 \%$ of the total whereas in the general eligible population they were $50.3 \%$ of the households.

The low-efficiency households tend to have the same heatigg fuel penetrations as the general eligible population with the exception of electric heating. Only $9.5 \%$ heated with electricity compared to $20 \%$ among all poor househotds. This may be attributable to the fact that the housing stock heating with electricity tends to be newer and thetefore, more energy efficient. The difference is spread rather evenly across naturad gas, fuel oil, kerosene and "No Heating Fuel Used." 


\subsubsection{Low-Efficiency Households: Energy Expenditures and Burden}

The average expenditure for residential energy for the low efftciency group was $\$ 1,084$, a figure that was above the average for ail low-income households by only 592 , a difference that was not statistically significant.

The single-family households in the low efficiency sample had average expenditures of $\$ 1,185$ comparable to $\$ 1,1$ I 5 for all the pogr in this type of dwelting. Residents in small multifamilly buildings had somewhat bigher average expenditures than the mean for all similarly situated lowincome households: $\$ 1,122$ as compared to $\$ 938$. Residents of mobite homes in the low-efficiency class had average expenditures of $\$ 807$ in 1990, well below the mean for low-incorne mobile horke residents in general, who spent an average of $\$ 978$ in 1990 . Expenditures by those living in large mettifamily dwellings were roughly comparable to those of the larger multifamity poputation at $\$ 620$.

The energy burden faced by low efficiency households in 1990 was $15.9 \%$ of income, not stakistically different than that of the all low-income population at $14.4 \%$.

Measured in rems of energy expenditures or energy burden this "lawnefficiency" subsel offers Iitcle in the way of insight as to the households within the Jow-income population that could most benefit from weatherization services. The absence of instlation or storm windows aione does not seem to set these housetolds apart in a meaningfil way from all eligible househoids. Put another way, the absence of storm windows in the Northeast and Midwest and the absence of a high level of attic insulation nationwide as reported in RECS do not appear to be good indicators of household energy efficiency.

\subsection{THE PERSISTENT-EXIGIBLE HOUSEHOLDS}

Households that qualified for weatherizalion and LIHEAP in both 1987 and 1990 totaled $17,254,000,61.9 \%$ of alt households that qualified in 1990 . They are of particular interest because they are a natural target group for the program in as much as their inadequate incomes and probiems with energy affordability persist over time.

As one might expect, this poptsation had a slightly higher partictipation rate in public assistance programs than the general Jow-income population. However, the difference is a matler of a few percentage points in the case of each program.

The etderly comprised a somewhat higher proportion of the persistent population, at $52.8 \%$ than of the 1990 population, in which $43.7 \%$ were households with elderly residents. The proportions of households with children and single-parent households were roughly comparable in the two samples but African-Americans were more heavily represented in the persistent eligible group. They comprised $24.6 \%$ of that set of houscholds and $18.5 \%$ of those eligible only in 1990. 
Expenditutes for residential energy by the persistently eligible population averaged $\$ 990$ in 1990, essentially the same as the "1990-only" population. There were no major distinctions between the two groups in terms of expenditures by housing type, with the exception of residents in mitufarnily buildings. The average expendicure in this group was $\$ 1.029$ for the persistent eligibles and 5938 for those eligible in 1990 alone.

The average income of the persistent population was $\$ 9,410$ compared to $\$ 10,048$ for the "1990-onjy" population but energy burdens were not significantly different. The only exception to this trend was among households using propane for heat. Their energy burden in the persistent population averaged $25.1 \%$ of income and in the "1990-only" population it averaged $18.1 \%$, largely as a consequence of higher fuel bills in the former group.

Though the energy-related characteristics of these bouseholds do not stand out compared to at) those eligitle in 1990, there are reasons that the persistent eligible population may deserve prioritization in the weatherization program, not the least of which is the persistence of need for help as well as eligibility. Their energy-affordability problerns appetr less likely to be solved by a positive change in their financial circumstances.

\subsection{THE WEATHERIZED POPULATION IN 1990}

The number of householids weacherized in the period from October 1989 through September of 1990 was 851 thousand based on the RECS for 1990. This count is two-thirds kigher than the estirate by Power et al.(1992) that approximately 500,000 units were weatherized in 1989 . This large difference is probabiy attributable to the small sample size for recentiy weatherized homes in the 1990 RECS.

3. Indeed, this relatively small sample does not offer signiftcant insights regarding the general characteristics of ail low-income households that have been weatherized and it is timpossible to derive meaningful data on income, expenditure, or energy burden for the full class of households weatherized across the past decade from any known data source. There are nevertheless some interesting points to be gleaned from the 1990 statistics.

Among households weatherized in 1990 the fuel-use distribution was roughly equivatenl to that for all low-income householids with a somewhat higher concentration on households using propane for heat. These comprised $15.3 \%$ of the weatherized sample. The major distinction between this subset and the others stadied for this report was in regard to housing type. Approximately $80.8 \%$ of the households weatterized lived in single-family homes, a significantly higher proportion than the 58.7 living in such housing in the general eligible population. The propartion of owners, at $59 \%$, was stightly higher than in the general low-income population. The greater percentage of single-family homes and owners feflects the orientation of most weatherization programs. including DOE's. 
The average income for the weatherized sample was $\$ 8,316$ which was somewhat below the average for all low-income householots bat this difference was not statistically significant because of the sample size. The energy burden averaged $17.6 \%$ but the margin of error for the sample is such as to range from below the average for alt eligibles at $14.4 \%$ to above the $19 \%$ burden of highexpenditure househotds. They certainiy did not have a burden comparable to that for the highburden or high-burden/high-expenóiture populations.

There were no statistically significant differences between the demographics and program participation rates of this group when compared to the generat efigible population. This finding was surprising in that LIHEAP paricipants often serve as a pool from which weatherization candidates are drawn. The tendency of the RECS and other surveys to underreport program participation together with the relatively small sample size may explain this result. 


\section{COMPARISON OF ELIGIBLE, HIGE-BURDEN AND HIGH-EXPENDITURE POPULATIONS AND CONCLUSIONS}

This chapter presents a comparison of the summary statiscics for the populations that are the focus of this study + the eligitble househotds, high-expenditure househoids, and high-burden Statistics are also presented for the relatively small sample of high-burden/highpenditure households. These statistics indicate that in many respects there is remarkable onsistency among the high-burden and high-expenditure subgroups relative to the overall lowicome population. The outstanding characteristics that distinguish the subgroups are the haracteristics that define them, namely energy expenditures for the high-expendilure group and prome for the high-burden group.

There is no discussion of regional data in this chapter. There are two reasons for this omission. First, the size of the subgroup samples at the regional level is not sufficiently large to permit statistically signiftcant comparisons for several key statistics. Second, the nature of the in selection process for the high-burden and high-expenditure households was based on comparisons $-\because$ -

sing

made among households in the same region and climate zone. By definition the houselholos in each subgroup are distributed along the same regional lines as the eligible population as a whole.

\subsection{HOUSING TYPE AND TENURE}

As Figure 6.1 shows there is very little distinction among subpopulations based on housing the differences between the percentages for single-family occupancy are not statistically , signiftcant, based on pair-wise t-tests at . I level of significance. The two differences that do emerge involve mobjle homes and large multifamijy units occupitd by high-expendilure households.

$\vec{y}$. Mobite homes are nearly $20 \%$ of the high-expenditure subgroup though they comprise only $8.2 \%$ of al] eligible households and $\mathbf{8 . 5 \%}$ of high-burden households. Mobile home residents may therefore be a subpopulation of particulaz interest from an energy efficiency perspective.

The percentage of households in the high-expenditure population that lives in large multifamily buildings is proportionally smalier than it is anong either eligible or high-burden households. The tendency to smajler unit size and lower expenditures per unit in large multifamily buildings helps explain this difference.

Figure 6.2 presents the summary data regarding housing tenure for the total eligible and subpopulations. It is clear from the table that there are no large differences to note regarding housing tentire on a national basis. 


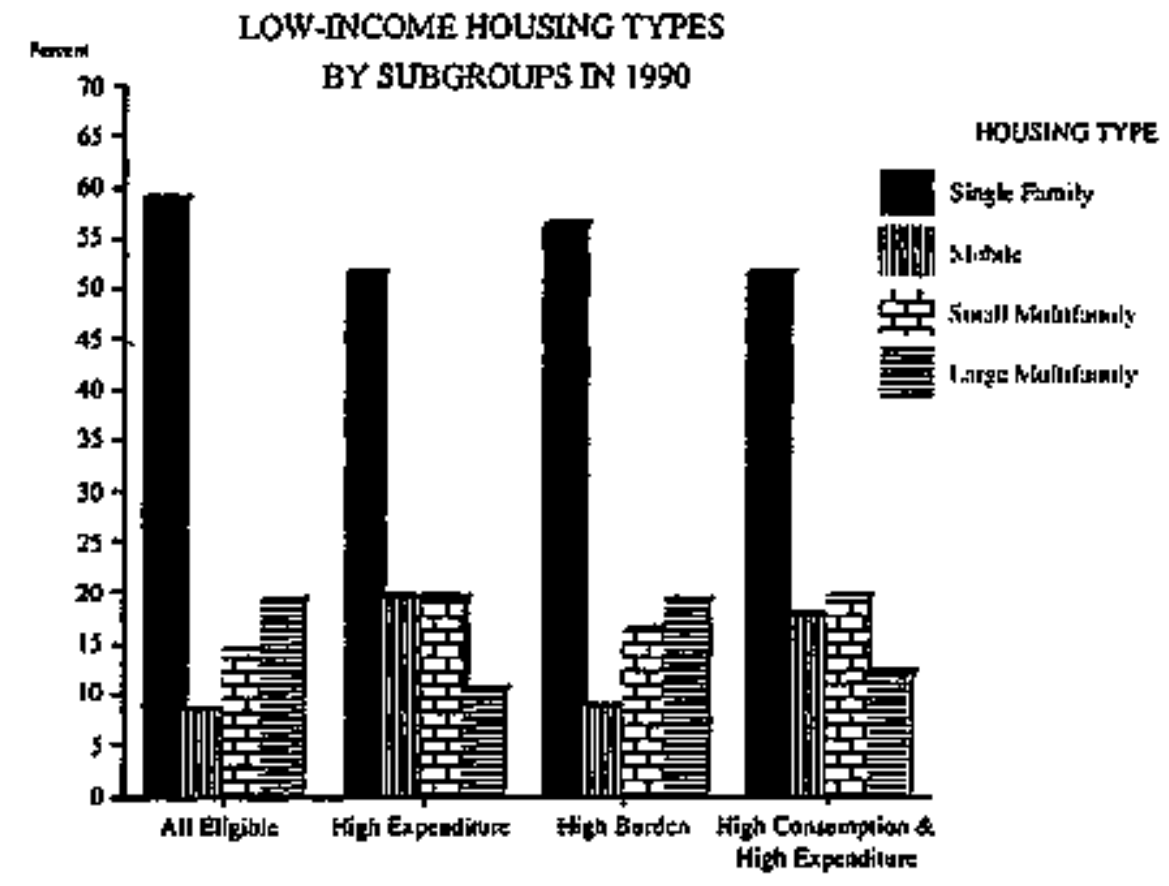

Flgure 6.1 Low-Income Housing Types by Subgroups

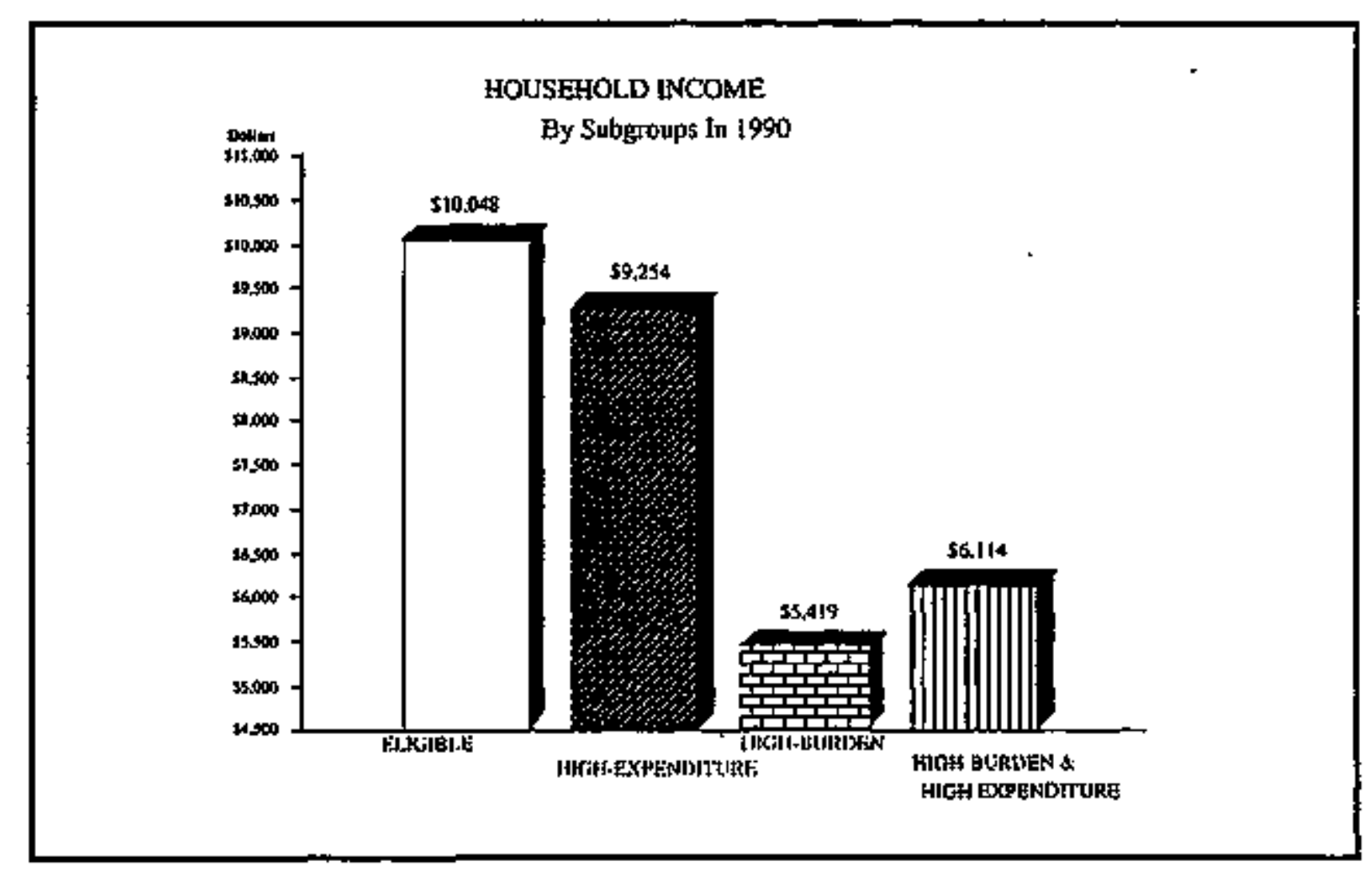

Figure 6.2 Low-Income Housing Tenure by Subgroups 


\section{DEMOGRAPHICS AND PROGRAM PARTICIPATION}

One would expect to see some differences among the vartous populations, particulatly in regard to program participation. Indeed, as Table 6.1 shows, high-burden households do have higher

triction sate of participation in AFDC, LIHEAP. and Food Stamps than does the eligible population as a f: whole. LIHEAP participation rates in particular are much greater for high-burcen households than : for all tow-income households, a resizl that is consistent with the legislative mandate of that program to serve households with the greatest energy burdens. The significantly lower incomes of highburden households relative to the eligible population as a whole as wetl as high-expendture households may also help to explain the higher public assistance participation rales for this group.

Table 6.1 Demographics and Program Participation Percent in 1990

\section{Percent in 1990}

\begin{tabular}{|c|c|c|c|c|}
\hline$\therefore$ & Eliglble & $\begin{array}{c}\text { High: } \\
\text { Expenditure } \\
\end{array}$ & Hlgh-Burden & $\begin{array}{c}\text { High-Gurden/ } \\
\text { High-axpenditure }\end{array}$ \\
\hline EIderly & $43.7 \%$ & $44.5 \%$ & $41.3 \%$ & $40.4 \%$ \\
\hline With Chlidren & $42.9 \%$ & $41.7 \%$ & $39.9 \%$ & $3 \mathrm{~B} .6 \%$ \\
\hline Atrican American & $18.5 \%$ & $27.3 \%$ & $25.9 \%$ & $29.7 \%$ \\
\hline Bingle Parent & $19.9 \%$ & $20.2 \%$ & $25.9 \%$ & $24.2 \%$ \\
\hline AFDC & $11.9 \%$ & $14.4 \%$ & $22.6 \%$ & $22.1 \%$ \\
\hline ËHEAP & $13.7 \%$ & $15.7 \%$ & $22.7 \%$ & $20.7 \%$ \\
\hline Food Stamos & $20.0 \%$ & $26,7 \%$ & $33.3 \%$ & $34.1 \%$ \\
\hline
\end{tabular}

Other demographic characteristics stch as the presence of senior citizens, chitldren, or singleparent families did not vary among the subgroups and eligible population to any significant degree. The exceptions to this are the African American population, which appears 10 be disproportionately represented in the high-burden and high-expenditure groups, and single-parent households. which are disproportionately represented in the high-burden population.

\subsection{INCOME, ENERGY EXPENDITURES, AND ENERGY BURDEN}

The eligible population constitutes approximately $30 \%$ of all U.S. househoids. In a group of this size there are certain to be tremendous variations around the average for household income and these are reflected in the income slatistics shown tn Figure 8. The average income for high-burden botsseholds was only $\$ 5,419$ compared to an average of $\$ 10,048$ for the entire eligible population. It is interesting to note that the average income of high-expenditure households at $\$ 9,254$ was not significantly differenl an average than that of the overali population. Here too, there is substantial 
variation arougd the mean. There are over two million households within the high-expenditure group that also qualify as high-burden households. Their average income was only $\$ 6,114$.

Energy expenditures, as shown in Figure 6.3, are remarkably consistent among the subpopulations which are all well above the average for all etigible households at $\$ 994$. The relatively smalt difference between the average expenditures of the high-expenditure and highburden groups is somewhat surprising given the fower income of the tatter population.

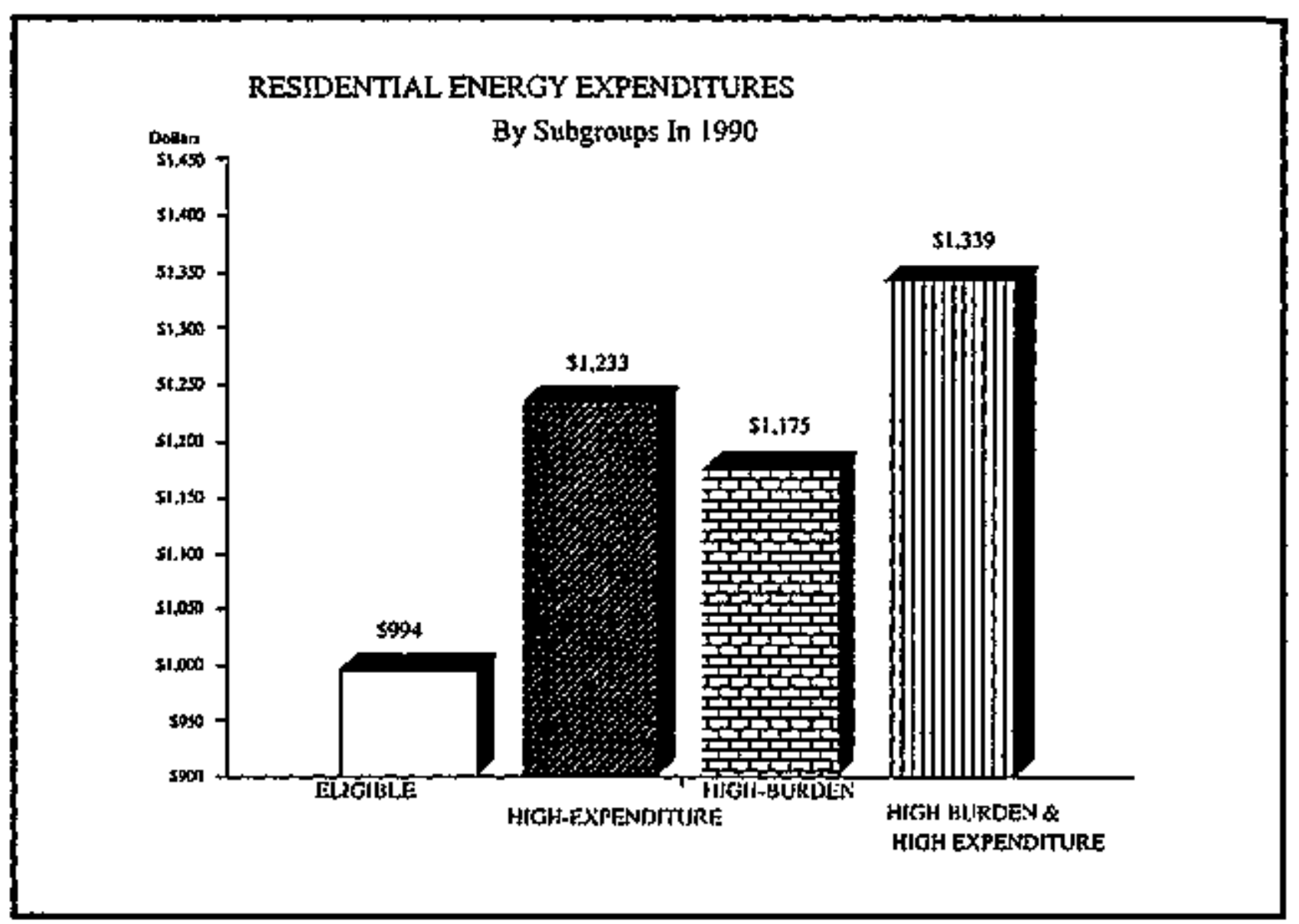

Figure 6.3 Residential Energy Expenditures by Subgroups

With expenditures that are near the levels of the least energy-efficient households and incomes well below the low-incone average, it is not surprising that the high-burden group has a much higher energy burden than the eligibles as a whole or the high-expenditure group. The highexpenditure greup has an average burden of $19.2 \%$, well above that of the low-income population as a whoie. But high-burden houscholds have an average burden of over 30\%, as shown in Figure 6.4. 


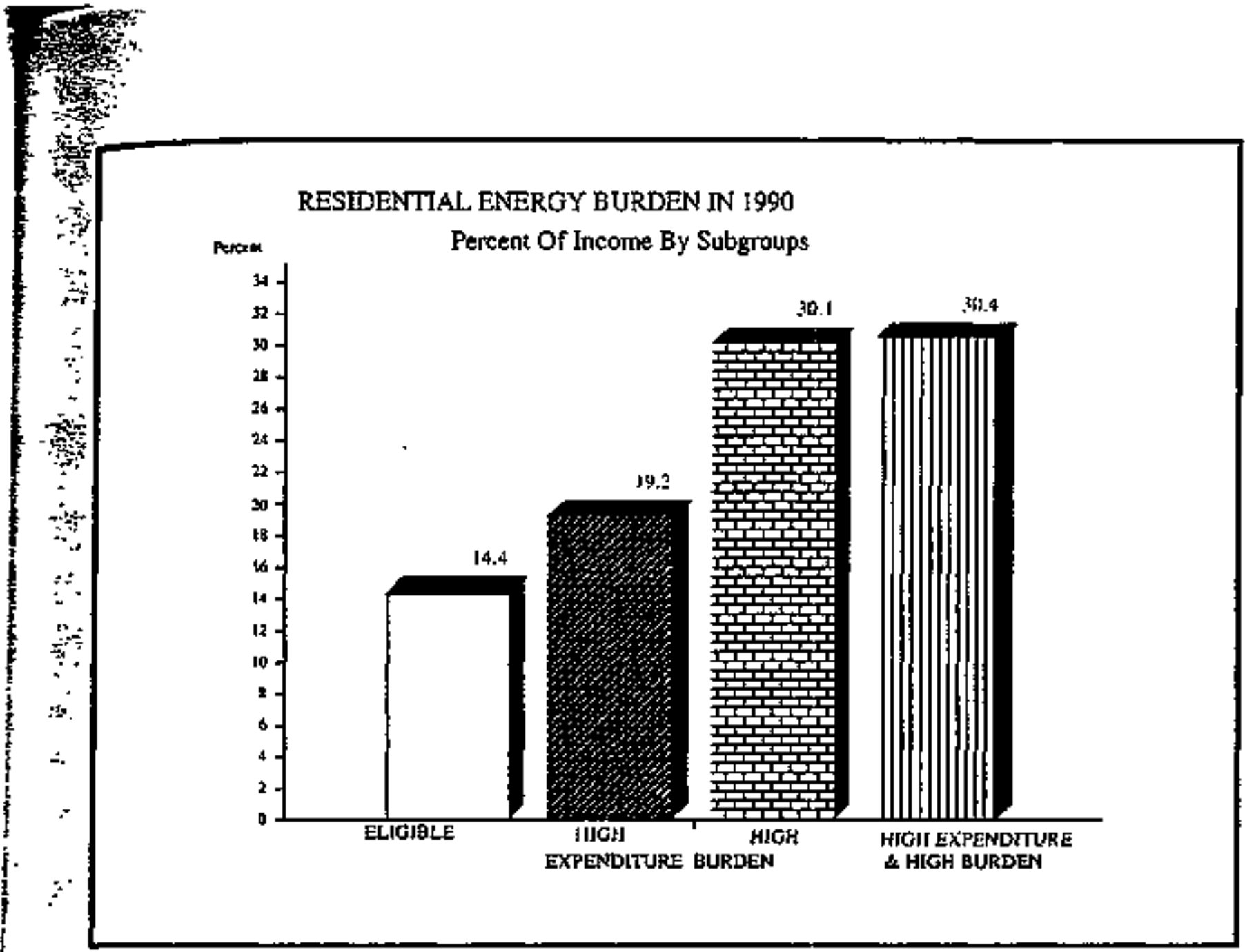

\section{Figure 6.4 Residential Energy Burden by Subgroups}

Again, it is important to note that high-burden and high-expenditure households overlap to a considerable degree. These households, who have the unenviable combination of high energy costs and very low incomes, comprise a logical target for attention from those seeking to maximize both the energy efficiency and distributive equity impacts of the weatherization program.

\subsection{STATISTICAL SUMMARY AND CONCLUSIONS}

The statistics allow the following comparisons to be drawn;

1) Average income for the eligible population is highter than that of the highexpenditure subpopulation and significantly higher than the average income for the high-burden population.

2) Both high-expenditure and high-burden households have higher average expenditures than do the ejigibles taken as a wholc. 
3) Expenditures by the high-expenditure households are not significantly higher than for the high-burden households.

4) There is a signiftcant difference in energy burden between the population of all efigible households at $14,4 \%$ and the high-expenditure households at $19.2 \%$.

5) There is an even latger gap between the high-burden households - with a mean burden of $30.1 \%$, and high+expenditure households.

6) Approximately $43 \%$ of the high-expenditure houstholds, 2.125 million, are also in the high-burden category. These households ase particularly worhy of greater attention in that they appear to offer a major energy efficiency and equiry opportunity.

The results of this analysis indicate, in broad boush strokes, the types of households that may be the appropriate focus of the federal low-income weatherizarion effort. Clearly the statistics presented here are not sufficienly specific to serve as a guide to state or local decisionmakers as to the types of households or housing that sthould be argeted for weatherization in their Jocales. There is, nonetheless. some value to these decisionmakers in knowing that an apparently ample stock of housing is available to which efficiency services can be applied to maximum efficiency and equity effect.

A logical focus for future research is a more in-depth evaluation of the demographics. location, housing, and energy proftle of the high-burten/high-expenditure group. This may prove useful to state, community, and utility weatherization specialists who are trying to maximize the returs for the low-income efficiency dollar. 


\section{APPENDIX A}

\section{DETAILED TABLES}

SET TABLES 4 


\section{APPENDIX A}

\section{TABLE A-1}

\section{ALL LIHEAP-ELIGIBLE HOUSEHOLDS NATIONAL}

THOUSANDS OF HOUSEROLDS

\begin{tabular}{|c|c|c|c|c|c|c|c|c|c|c|c|c|c|c|c|}
\hline \multirow[b]{3}{*}{$\begin{array}{l}\text { Primary } \\
\text { lleating } \\
\text { Fued }\end{array}$} & \multicolumn{12}{|c|}{ Hoosing Type and Teourc } & & & \multirow[b]{3}{*}{$\begin{array}{l}\text { All } \\
\text { lhowes } \\
\text { llowt }\end{array}$} \\
\hline & \multicolumn{3}{|c|}{ Motile Howe } & \multicolumn{3}{|c|}{ Singte Fanily } & \multicolumn{3}{|c|}{ Somett Mullitamily } & \multicolumn{3}{|c|}{ Large Muttiramily } & \multicolumn{2}{|c|}{ All Housing Types } & \\
\hline & Omi & Real & $\begin{array}{l}\text { Both } \\
\text { Tesures }\end{array}$ & Ono & R:ol & $\begin{array}{l}\text { Bolb } \\
\text { Teaurs: }\end{array}$ & Ono & Remt & $\begin{array}{l}\text { Doth } \\
\text { Tenurex }\end{array}$ & $O_{m p}$ & Reat & $\begin{array}{l}\text { Bokh } \\
\text { Tenures }\end{array}$ & Omn & Peat & \\
\hline Nhtural Gas & 437 & 280 & $\pi 7$ & $\$, 931$ & 2,679 & 8610 & 466 & 2796 & 2,601 & s5 & 2,649 & 3,74 & 6,899 & 7,814 & $14, \pi 3$ \\
\hline Lleatrivity & 320 & 81 & 401 & $1,5 \times 1$ & $9 \pi$ & 2,515 & 46 & 665 & 71 & 59 & 1,898 & 1,958 & 1,963 & 3,602 & S,sBs \\
\hline Fuel OU & 41 & 20 & 61 & 1,621 & 30 & 1,94 & 153 & 331 & 483 & 30 & 601 & 601 & 1,844 & 1,275 & 3,119 \\
\hline Ketoecpo & $\boldsymbol{7 4}$ & 12 & 196 & 106 & 161 & 246 & $\mathfrak{3}$ & 0 & 13 & 0 & 20 & 20 & 193 & 302 & 495 \\
\hline Propace & 547 & 164 & 711 & 1,102 & 265 & 1,367 & 37 & 23 & 40 & 0 & 0 & - & 1,665 & 452 & 2,117 \\
\hline Other Pucks & 183 & 3 & 90 & 1,226 & 200 & 1,476 & 0 & 0 & 0 & $\mathbf{0}$ & 0 & 0 & 1,409 & 257 & 1,666 \\
\hline $\begin{array}{l}\text { No Itenting } \\
\text { Puel Uneed }\end{array}$ & $\theta$ & 0 & 0 & 6 & 112 & 17 & 0 & 19 & 29 & 0 & o. & 0 & 65 & 23 & 197 \\
\hline $\begin{array}{l}\text { All } \\
\text { Jtousebolds }\end{array}$ & 1,602 & 674 & $22 n$ & 11,589 & 4,767 & 16,355 & 691 & $3,2 \mathrm{~N}$ & 3,938 & 14 & $s, 168$ & 5,313 & 14,029 & 13,854 & $278: 53$ \\
\hline
\end{tabular}




\section{APPENDDX A}

TABLE A-2

ALL LIHEAP-ELIGIBLE HOUSEHOLDS NATIONAL

\section{PERCENT OF HOUSEHOLIS}

\begin{tabular}{|c|c|c|c|c|c|c|c|c|c|c|c|c|c|c|c|}
\hline \multirow[b]{3}{*}{$\begin{array}{l}\text { Pyinay } \\
\text { Henting } \\
\text { Fretl }\end{array}$} & \multicolumn{12}{|c|}{ Hoasiog Type and Testre } & & & \multirow[b]{3}{*}{$\begin{array}{l}\text { Al } \\
\text { Houst } \\
\text { Iloids }\end{array}$} \\
\hline & \multicolumn{3}{|c|}{ Molik Home } & \multicolumn{3}{|c|}{ Singe Pamily } & \multicolumn{3}{|c|}{ Souty Multisanily } & \multicolumn{3}{|c|}{ LAfar Mullifamity } & \multicolumn{2}{|c|}{ All Housiog Tyer } & \\
\hline & Om & Rebl & $\begin{array}{l}\text { lokn } \\
\text { Tentres }\end{array}$ & Dent & Rteal & $\begin{array}{l}\text { Botb } \\
\text { Teaurs }\end{array}$ & ow & Renl & $\begin{array}{l}\text { Bonth } \\
\text { Tentures }\end{array}$ & Ona & RenI & $\begin{array}{l}\text { Toth } \\
\text { Tenuttr }\end{array}$ & Onv & Rent & \\
\hline Nalural Gas & t. .6 & 10 & 2.6 & 21,3 & 9,6 & 30,9 & 1.7 & 7.9 & 9.6 & 02 & 95 & 9.7 & 24.7 & $\mathbf{2 8 0 0} 0$ & 527 \\
\hline Electrikily & 1.1 & d.3 & $1 A$ & 5.5 & 35 & 9.0 & 02 & 24 & 25 & 0.2 & 6.8 & 7.0 & 20 & 13.0 & 20.0 \\
\hline Funel oil & 0.1 & ot & 02 & 5.8 & 12 & 7.0 & $0 s$ & 12 & 1.7 & o.t & 22 & 23 & 66 & 4,6 & 113 \\
\hline Keropese & 03 & QA & a.7 & $0 x$ & 0.6 & 1.0 & 0.0 & 0.0 & 0.0 & 0.0 & 0.1 & a. & 0.7 & 1.1 & 1.6 \\
\hline Propape & 20 & 0.6 & 25 & 4.6 & 1.0 & 4.9 & 0.1 & 0.1 & a.l & 0.0 & 0.0 & 0.f & 5.0 & 1.6 & 76 \\
\hline Othet thets & 0.7 & 0.0 & 0.7 & 4.4 & 0,9 & 53 & 0.8 & 00 & 00 & 0,0 & 0.0 & 0.0 & 5.1 & 09 & 6.0 \\
\hline $\begin{array}{l}\text { No fleting: } \\
\text { Pued Uned }\end{array}$ & 0.0 & 0.0 & 0.0 & 0.2 & 0.4 & 0.6 & 0.0 & o.t & a.t & 0.0 & 0.0 & 0.0 & 0.2 & as & 0.7 \\
\hline $\begin{array}{l}\text { All } \\
\text { Flouscrbolds }\end{array}$ & $3 . t$ & 24 & 82 & 41.6 & 17.1 & 507 & 25 & 116 & 14.1 & 0.5 & 11.5 & 19.1 & 503 & $\$ 9.7$ & 1000 \\
\hline
\end{tabular}




\section{APPENDLX A}

TABLE A-3

\section{ALL LIHEAP-ELIGIBIE HOUSEHOLDS REGIONAL / NORTHRAST}

THOUSANDS OF HOUSEHOL.DS

\begin{tabular}{|c|c|c|c|c|c|c|c|c|c|c|c|c|c|c|c|}
\hline \multirow[b]{3}{*}{$\begin{array}{l}\text { Primary } \\
\text { Ileating } \\
\text { Fots }\end{array}$} & \multicolumn{12}{|c|}{ Hoosing Type and Tenture } & & & \\
\hline & \multicolumn{3}{|c|}{ Moblle liowe } & \multicolumn{3}{|c|}{ Stapte Parnity } & \multicolumn{3}{|c|}{ Sout Muhithmily } & \multicolumn{3}{|c|}{ 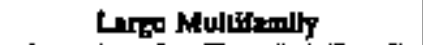 } & \multicolumn{2}{|c|}{ All ltawing Typex } & \multirow[b]{2}{*}{$\begin{array}{l}\text { All } \\
\text { Housea } \\
\text { Itodts }\end{array}$} \\
\hline & Omb & Reqt & $\begin{array}{l}\text { Boch } \\
\text { Tequirts }\end{array}$ & om & Reat & $\begin{array}{l}\text { Both } \\
\text { Tenurra }\end{array}$ & Omn & Reat & $\begin{array}{l}\text { Bott } \\
\text { Tenures }\end{array}$ & Owa & Rent & $\begin{array}{l}\text { Both } \\
\text { Teopere }\end{array}$ & Onil & Reot & \\
\hline Natural & 0 & t? & 17 & 74 & $\mathbf{2 n}$ & 945 & 273 & 680 & 953 & 0 & 590 & $s 90$ & 987 & 1,5t9 & 2506 \\
\hline Elestrictity & ts & a & 18 & 206 & 44 & tso & 26 & 90 & 100 & 0 & tos & 188 & 140 & Int & $46 i$ \\
\hline Puel Oil & 0 & g & 9 & 805 & LA & 959 & 153 & $\mathbf{x 2}$ & 404 & $\mathbf{3 0}$ & 601 & 631 & 987 & 1,016 & 2,000 \\
\hline Kerosede & 74 & 40 & 115 & 0 & 17 & 17 & to & $\mathbf{0}$ & 13 & 0 & 0 & 0 & 68 & 57 & 145 \\
\hline Propane & 35 & s & 35 & 16 & 0 & 16 & 0 & i) & 0 & 0 & 0 & 0 & 51 & 0 & 59 \\
\hline Other Poets & $\mathbf{0}$ & 0 & 0 & 106 & 0 & 100 & 0 & 0 & 0 & 0 & 0 & 0 & 106 & 0 & 106 \\
\hline $\begin{array}{l}\text { No Itenting } \\
\text { Puel Utesd }\end{array}$ & & & & & & & & & & & & & & & \\
\hline All & 229 & $\$ 6$ & 294 & 1,746 & 413 & 2,193 & 453 & 1,022 & 1,477 & $\mathbf{3 0}$ & $t_{i}+57$ & 1,409 & 2.59 & 2,914 & $s, 273$ \\
\hline
\end{tabular}

Soure: t990 Residential Energy Consumpotion Survey 


\section{APPENDIX A}

\section{TABLE A-4}

\section{ALL LIHEAP-ELIGIBLE HOUSEHOLDS REGIONAL / NORTHEAST}

\section{PERCENTT OF HOUS\&HOLDS}

\begin{tabular}{|c|c|c|c|c|c|c|c|c|c|c|c|c|c|c|c|}
\hline \multirow[b]{3}{*}{$\begin{array}{l}\text { Priningy } \\
\text { Heating } \\
\text { Foel }\end{array}$} & \multicolumn{12}{|c|}{ Honsing Type and Teawe } & & & \multirow[b]{3}{*}{$\begin{array}{l}\text { All } \\
\text { House } \\
\text { flows }\end{array}$} \\
\hline & \multicolumn{3}{|c|}{ Mobile Home } & \multicolumn{3}{|c|}{ Sinefe Pamily } & \multicolumn{3}{|c|}{ Serill Multirananty } & \multicolumn{3}{|c|}{ tegr Multifunity } & \multicolumn{2}{|c|}{ 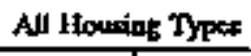 } & \\
\hline & Ont & Recnl & $\begin{array}{l}\text { Beth } \\
\text { Teaures }\end{array}$ & $a_{m p}$ & Rent & $\begin{array}{l}\text { Both } \\
\text { Teaurs }\end{array}$ & Omn & Renl & $\begin{array}{l}\text { Both } \\
\text { Tenuras: }\end{array}$ & Omo & Fent & $\begin{array}{l}\text { Both } \\
\text { Tenures }\end{array}$ & ONo & Rept & \\
\hline Natural Gas & D.o & 0.3 & 0.3 & 135 & 4.4 & 179 & 5.2 & 129 & 1B.1 & 0.0 & 112 & $\mathbf{t 1 2}$ & 187 & 288 & 435 \\
\hline Deaticily & 0.3 & 0.0 & 0.3 & 20 & 08 & 28 & 0.3 & 1.3 & 20 & 0.0 & 3.6 & 3.6 & 27 & 61 & B.7 \\
\hline Tuel Oil & 0.0 & 02 & 02 & $\mathbf{t 5 3}$ & 29 & 182 & 2.9 & 48 & 2.7 & 0.6 & 11.4 & 120 & 18.7 & 19.3 & 380 \\
\hline XENotede & 14 & 09 & 22 & 0.0 & 0.3 & 0.3 & 03 & 0.0 & 03 & $\infty$ & 0.0 & 0.0 & 1.7 & 1.1 & 28 \\
\hline Propanc & 0.7 & 0.0 & 0.7 & 0.3 & 0.0 & 03 & 0.0 & 0.0 & 0.0 & 0.0 & 0.0 & 0.0 & 10 & 0.0 & 1.0 \\
\hline Oubet Pues: & 0.0 & 0.0 & 0.0 & 20 & 00 & 20 & 0.0 & 0.0 & 0.0 & 0.0 & D.o & 0.0 & 20 & 0.0 & 20 \\
\hline $\begin{array}{l}\text { No llesting } \\
\text { Puet Utoed }\end{array}$ & & & & & & & & & & & & & & & \\
\hline $\begin{array}{l}\text { All } \\
\text { Ilousebolds }\end{array}$ & 24 & 13 & 3.7 & 33.1 & 85 & 11.6 & B.6 & 19.4 & 2 Alo & 06 & 20.2 & 26.7 & 4.7 & sst & 1000 \\
\hline
\end{tabular}




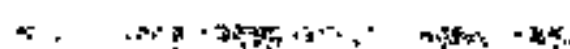

(a).

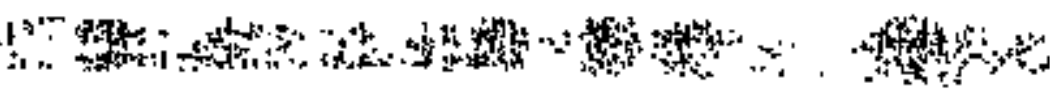

APPENDDX A

TABLE A-5

ALL LIFFAP-ELIGIBLE HOUSEHOLDS REGIONAL / MIDWEST

\section{THOUSANDS OF HOUSEHOLDS}

\begin{tabular}{|c|c|c|c|c|c|c|c|c|c|c|c|c|c|c|c|}
\hline \multirow[b]{3}{*}{$\begin{array}{l}\text { Primary } \\
\text { lieating } \\
\text { Fod }\end{array}$} & \multicolumn{12}{|c|}{ Honsins Type and Tenore } & & & \multirow[b]{3}{*}{$\begin{array}{l}\text { As } \\
\text { House } \\
\text { Hotets }\end{array}$} \\
\hline & \multicolumn{3}{|c|}{ Mobile Home } & \multicolumn{3}{|c|}{ Singte Panily } & \multicolumn{3}{|c|}{ Savell Mulifumily } & \multicolumn{3}{|c|}{ Lege Multitamily } & \multicolumn{2}{|c|}{ All lowsing Typer } & \\
\hline & Own & Rent & $\begin{array}{l}\text { Both } \\
\text { Ttautes }\end{array}$ & Owo & $\operatorname{Res}$ & $\begin{array}{l}\text { Bowb } \\
\text { Tedtres }\end{array}$ & Ong & Real & $\begin{array}{l}\text { look } \\
\text { Tebures }\end{array}$ & Om & Rent & $\begin{array}{l}\text { Both } \\
\text { Teatre }\end{array}$ & OmL & $R \in \mathbf{a l}$ & \\
\hline Nutural Gus & 539 & 63 & $\mathbf{2 0 2}$ & $1, \pi \theta$ & 847 & 2,626 & $1 \pi$ & 658 & 829 & $\boldsymbol{v}$ & 632 & 676 & 2,123 & 3,200 & $1 ; 3$ \\
\hline Wectricity & 61 & o & 61 & 24 & a & $2 \mathrm{at}$ & 0 & 9 & $\mathbf{n}$ & 43 & $\mathbf{9 7}$ & 135 & 328 & 181 & $s 12$ \\
\hline Pued Ox & 0 & 0 & 0 & 306 & 61 & 368 & 0 & 24 & 24 & 0 & 0 & 0 & 306 & 85 & $3 x$ \\
\hline Kenceloe & 0 & 0 & a & 0 & 0 & 0 & 0 & 0 & 0 & 0 & 20 & $\mathbf{2 0}$ & o & 20 & 20 \\
\hline Propase & 169 & 53 & $m$ & 34 & 61 & 125 & 17 & $\mathbf{x}$ & 40 & 0 & 0 & 0 & 560 & 137 & $\theta n$ \\
\hline Othet Torets & 80 & 7 & 8 & 358 & So & 413 & 0 & 0 & 0 & 0 & o & 0 & 438 & 6 & 501 \\
\hline $\begin{array}{l}\text { No Henting } \\
\text { Poed Uthod }\end{array}$ & & & & & & & & & & & & & & & \\
\hline $\begin{array}{l}\text { All } \\
\text { Ilows tolds }\end{array}$ & 49 & 23 & 573 & 3,040 & 1,028 & 1,065 & 197 & $n$ & 9s & 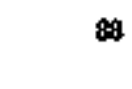 & 743 & $B M$ & 3,765 & 2,689 & 6,451 \\
\hline
\end{tabular}

Sourte: 1990 Resdential Energy Consumption Surwy 


\section{APPENDIX A}

\section{TABLE A-6}

\section{ALL LIHEAP-ELIGELE HOUSEHOLDS}

REGIONAL / MIDWEST

\section{FERCENT OF HOUSEHOLLS}

\begin{tabular}{|c|c|c|c|c|c|c|c|c|c|c|c|c|c|c|c|}
\hline \multirow[b]{3}{*}{$\begin{array}{l}\text { Prinary } \\
\text { leating } \\
\text { Poed }\end{array}$} & \multicolumn{12}{|c|}{ Hoosites Type and Tenme } & & & \multirow[b]{3}{*}{$\begin{array}{l}\text { All } \\
\text { Houste } \\
\text { Holds }\end{array}$} \\
\hline & \multicolumn{3}{|c|}{ Mobile Itros } & \multicolumn{3}{|c|}{ Single Pumily } & \multicolumn{3}{|c|}{ Senass Mutifumily } & \multicolumn{3}{|c|}{ Lefge Mattifuming } & \multicolumn{2}{|c|}{ All lkonsing Typos } & \\
\hline & Ong & Reat & $\begin{array}{l}\text { Boih } \\
\text { Tequrs }\end{array}$ & om & Repir & $\begin{array}{l}\text { Both } \\
\text { Tesurex }\end{array}$ & Onp & Rzol & $\begin{array}{l}\text { Bolb } \\
\text { Teovrs }\end{array}$ & Own & Rnot & $\begin{array}{l}\text { Bolb } \\
\text { Tenurs }\end{array}$ & Owd & Reat & \\
\hline Natural Gas & 21 & 1.0 & 3.1 & 27.6 & 13.1 & $\$ .7$ & 26 & 102 & 128 & 0.7 & 9 & 105 & 33.0 & 34. I & 67.1 \\
\hline Deretricity & 0.9 & 0.0 & 0.9 & 35 & 0.0 & 35 & 0.0 & 14 & 14 & 0.7 & $1 A$ & 2.1 & 5.1 & 29 & 79 \\
\hline Piect Dil & $\mathbf{0 . 0}$ & 0.0 & 0.0 & 1.7 & 0.9 & 5.7 & 0.0 & at & 0,4 & 0,0 & 0.0 & 0.0 & 4.7 & 13 & 8.1 \\
\hline Teroceace & a., & 0.0 & 0,0 & 0.0 & 0.0 & 0.0 & 0.0 & 0.0 & 0.0 & 0.0 & 0.3 & 03 & 0.0 & 0.3 & 03 \\
\hline Propano & 26 & 08 & 3.4 & $5 \beta$ & 0.9 & 6.7 & 03 & 0.4 & o. & 0.0 & 0.0 & 0.0 & 8.7 & 2.1 & 10.8 \\
\hline Oubet Puxts & 12 & 0,1 & 1.4 & ss & 0.9 & 84 & 0.1 & 0.0 & 00 & 00 & 0.0 & 0.0 & 6.8 & 1.0 & 78 \\
\hline \multicolumn{16}{|l|}{$\begin{array}{l}\text { No Henting } \\
\text { Joced Uloed }\end{array}$} \\
\hline 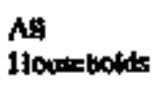 & 7.0 & 1.9 & 89 & $\$ 1.1$ & 5.9 & 630 & 29 & 124 & 152 & 14 & ins & 129 & 583 & 41.7 & 100.0 \\
\hline
\end{tabular}




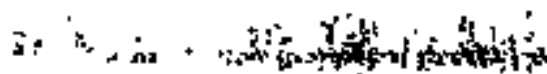

APPENDIX A

\section{TABLE A-7}

\section{ALL LIHEAP-ELIGIBLE HOUSEHOLDS}

\section{REGIONAL / SOUTH}

THOUSANDS OF HOUSEHOLDS

\begin{tabular}{|c|c|c|c|c|c|c|c|c|c|c|c|c|c|c|c|}
\hline \multirow[b]{3}{*}{$\begin{array}{l}\text { Primary } \\
\text { lleating } \\
\text { Fow }\end{array}$} & \multicolumn{12}{|c|}{ Honsies Type and Tenure } & & & \multirow[b]{3}{*}{$\begin{array}{l}\text { All } \\
\text { llowese } \\
\text { 1fold4 }\end{array}$} \\
\hline & \multicolumn{3}{|c|}{ Mobtis Hoone } & \multicolumn{3}{|c|}{ Singex Pamily } & \multicolumn{3}{|c|}{ Smati Mullifemily } & \multicolumn{3}{|c|}{ LFultitumily } & \multicolumn{2}{|c|}{ All 1fouting Types } & \\
\hline & Ona & Reat & $\begin{array}{l}\text { Bowk } \\
\text { Teatres }\end{array}$ & own & Real & $\begin{array}{l}\text { Botb } \\
\text { Tenures }\end{array}$ & and & Real & $\begin{array}{l}\text { Botb } \\
\text { Tenurs }\end{array}$ & Ond & Real & $\begin{array}{l}\text { Both } \\
\text { Tenutes }\end{array}$ & Own & Rtot & \\
\hline Natural Ges & 142 & 62 & 201 & 2,548 & 䑶 & 3,365 & $\mathbf{2}$ & 468 & 40 & 0 & 529 & 523 & $2 \pi 12$ & 1,870 & 4583 \\
\hline Dlectotiktly & 194 & 17 & 213 & $\mathbf{9 0 6}$ & 383 & 1,493 & D & 299 & 289 & 0 & 1,039 & 1,099 & 1,102 & 1,928 & 3,000 \\
\hline Juel Oil & 41 & 11 & 52 & 294 & 82 & 576 & o & 56 & 36 & o & 6 & 0 & 5.5 & 149 & 63 \\
\hline Kerosene & $\mathbf{0}$ & 81 & 81 & 106 & 14 & 249 & 0 & 0 & a & o & o & 0 & 106 & $\mathbf{m}$ & 300 \\
\hline Propase & 228 & 99 & 328 & $\min$ & 137 & $m s$ & 0 & 0 & 0 & 0 & 0 & 0 & 6.65 & 208 & 1,100 \\
\hline Otbet Iusts & 31 & 0 & 31 & H & 101 & 586 & 0 & 0 & 0 & 0 & 0 & a & sws & 101 & 616 \\
\hline $\begin{array}{l}\text { No Itentins } \\
\text { Puel Uted }\end{array}$ & 0 & o & 0 & 27 & 0 & $n$ & 0 & 0 & 0 & 0 & 0 & 0 & 22 & 0 & $n$ \\
\hline $\begin{array}{l}\text { All } \\
\text { Ilousebolds }\end{array}$ & 657 & $2 n$ & 9 & 5,199 & 1,866 & 3,065 & $\mathbf{n}$ & 812 & ans & 0 & 1,562 & 1,562 & $S, B S B$ & 4,511 & 10,768 \\
\hline
\end{tabular}




\section{APPENDIX A}

TABLE A-8

\section{ALL LIHEAP-ELIGIBLE HOUSEHOLDS REGIONAL / SOUTH}

\section{PERCENT OF HOUSEIIOLDS}

\begin{tabular}{|c|c|c|c|c|c|c|c|c|c|c|c|c|c|c|c|}
\hline \multirow[b]{3}{*}{$\begin{array}{l}\text { Primasy } \\
\text { lfeating } \\
\text { Fed }\end{array}$} & \multicolumn{12}{|c|}{ Hoosing Type and Tenpre } & & & \multirow[b]{3}{*}{$\begin{array}{l}\text { Alt } \\
\text { Honss } \\
\text { Holds }\end{array}$} \\
\hline & \multicolumn{3}{|c|}{ Mobile IJoms } & \multicolumn{3}{|c|}{ Sintie 1'amity } & \multicolumn{3}{|c|}{ Stratl Mattilamily } & \multicolumn{3}{|c|}{ 1.srga Multitsaily } & \multicolumn{2}{|c|}{ All fousing Types } & \\
\hline & Own & $R=0 t$ & $\begin{array}{l}\text { Botb } \\
\text { Teautes }\end{array}$ & Owa & Rent & $\begin{array}{l}\text { Botb } \\
\text { Tequres }\end{array}$ & Ond & Reat & $\begin{array}{l}\text { lowh } \\
\text { Teautes }\end{array}$ & Owo & Rent & $\begin{array}{l}\text { Botb } \\
\text { Teotse }\end{array}$ & Own & Rent & \\
\hline Nalucal Cus & 14 & 0.5 & 20 & 24.6 & 7.9 & 325 & 02 & 45 & 4.7 & 0.0 & 5.0 & 5.0 & 20 & 180 & 412 \\
\hline Eoxtridity & 19 & 0.2 & 20 & B.B. & 5.6 & 144 & 0.0 & 28 & 2.8 & 0.0 & 10.0 & 10.0 & 106 & 186 & $29 ?$ \\
\hline Potel Dil & 0.4 & 0.1 & as & 48 & 0.8 & 5.6 & 0.0 & 0.5 & DS & 6.8 & 0.0 & 9.0 & 52 & 1.4 & 65 \\
\hline Keroceac & 0.0 & 0.8 & 0.8 & 1.0 & 1.4 & 24 & 0.0 & 0.0 & 0.0 & 0.0 & 0.0 & 0.0 & 10 & 27 & 31 \\
\hline Propape & 23 & 50 & 32 & 6.1 & 13 & is & 0.0 & $\infty$ & 0.0 & 0.0 & 0.0 & 0.0 & 8.3 & 23 & 30.6 \\
\hline Other Puek & 03 & 0.0 & 0.3 & 47 & 1,0 & 5.6 & a.t & bit & 0,0 & 0,0 & 0.0 & 0.0 & 5.0 & 1.0 & 5.5 \\
\hline $\begin{array}{l}\text { No dieathere } \\
\text { Pued Lhod }\end{array}$ & 0.0 & 0.0 & 00 & 02 & 0.0 & 02 & ado & 0.0 & 0.0 & 00 & 0.0 & 0.0 & 0.2 & 0.0 & $\mathrm{D}_{2}$ \\
\hline $\begin{array}{l}\text { Nll } \\
\text { flowsibolsts }\end{array}$ & 6.1 & 26 & 68 & 50.1 & 180 & a1 & 02 & 78 & 8.1 & 00 & 15,1 & $\mathbf{t s . 1}$ & 565 & as & 100.1 \\
\hline
\end{tabular}




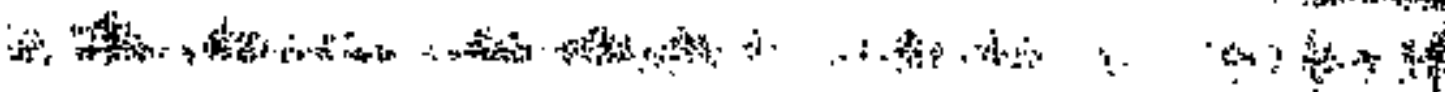

\section{APPENDIX A}

TABLE A-9

\section{ALL LIHEAP-ELIGELE HOUSEHOLDS REGIONAL / WEST}

THOUSANDS OF ROUSEIIOLDS

\begin{tabular}{|c|c|c|c|c|c|c|c|c|c|c|c|c|c|c|c|}
\hline \multirow[b]{3}{*}{$\begin{array}{l}\text { Priming } \\
\text { Ileatios } \\
\text { Foed }\end{array}$} & \multicolumn{12}{|c|}{ Honslos Type and Tendre } & & & \multirow[b]{3}{*}{$\begin{array}{l}\text { All } \\
\text { Houser } \\
\text { Itolds }\end{array}$} \\
\hline & \multicolumn{3}{|c|}{ Motite Ilowe } & \multicolumn{3}{|c|}{ Single linmily } & \multicolumn{3}{|c|}{ Sonall Moltiramily } & \multicolumn{3}{|c|}{ Inge Mulifamity } & \multicolumn{2}{|c|}{ All Housing Thes } & \\
\hline & Ond & Reat & $\begin{array}{l}\text { Boub } \\
\text { Teruses }\end{array}$ & Omp & Frnt & $\begin{array}{l}\text { Both } \\
\text { Teowes }\end{array}$ & Omn & Rent & $\begin{array}{l}\text { Booth } \\
\text { Téaurse }\end{array}$ & Owr & Reat & $\begin{array}{l}\text { Both } \\
\text { Tenumar }\end{array}$ & Own & Rent & \\
\hline Nalunit Gas: & 156 & 139 & $2 \infty$ & 61 & 703 & 1,674 & 0 & 399 & 399 & 10 & 900 & 915 & 1,058 & 2,205 & 3280 \\
\hline Dectaicily & 46 & 64 & 110 & 301 & 150 & 651 & 30 & 194 & 24 & 16 & $\operatorname{sen}$ & 39 & $3+3$ & 1,189 & 5,581 \\
\hline Puel OAt & 0 & 0 & 0 & $\mathbf{s}$ & $\mathbf{s}$ & 41 & B & - & 0 & $\theta$ & 0 & 0 & Ls & $x$ & di \\
\hline \multicolumn{16}{|l|}{ Keresente } \\
\hline Propanc & 114 & $\mathbf{n}$ & 125 & is & $\mathbf{s}$ & 141 & 0 & 0 & 0 & 0 & 0 & 0 & 190 & 36 & 236 \\
\hline Otber Pucts & $n$ & 0 & $\pi$ & $27 \pi$ & 93 & 371 & o & b & 0 & 0 & 0 & 0 & 350 & 93 & 413 \\
\hline $\begin{array}{l}\text { No Hewlos } \\
\text { Putel Uned }\end{array}$ & 0 & 0 & 0 & 42 & 112 & tss & 0 & 19 & 19 & 0 & 0 & 0 & 4 & 132 & 174 \\
\hline $\begin{array}{l}\text { All } \\
\text { Iloutebolyts }\end{array}$ & 388 & 214 & 60 & 1,600 & 1,429 & 3,003 & 30 & 613 & GA3 & 26 & 1,484 & $1, \$ 10$ & 2,048 & 3,740 & 5,780 \\
\hline
\end{tabular}




\section{APPENDLX A}

\section{TABLE A-10}

\section{ALL LHHEAP-ELIGIBLE HOUSEHOLDS \\ REGIONAL / WEST}

PERCENT OF HOUSGHOLOS

\begin{tabular}{|c|c|c|c|c|c|c|c|c|c|c|c|c|c|c|c|}
\hline \multirow[b]{3}{*}{$\begin{array}{l}\text { Primang } \\
\text { Efeating } \\
\text { Fuel }\end{array}$} & \multicolumn{12}{|c|}{ Houstos Type and Tenore } & & & \multirow[b]{3}{*}{$\begin{array}{l}\text { Alt } \\
\text { Houre } \\
\text { Hokd }\end{array}$} \\
\hline & \multicolumn{3}{|c|}{ Matide Hoose } & \multicolumn{3}{|c|}{ Sinde Pamity } & \multicolumn{3}{|c|}{ Smatl Mulififamilly } & \multicolumn{3}{|c|}{ 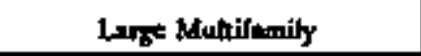 } & \multicolumn{2}{|c|}{ Al thouring Thes } & \\
\hline & Ond & Reat & $\begin{array}{l}\text { Bolt } \\
\text { Teroses }\end{array}$ & Denn & Reas & $\begin{array}{l}\text { Botb } \\
\text { Teance }\end{array}$ & Omn & Rent & $\begin{array}{l}\text { Douk } \\
\text { T'course }\end{array}$ & Owo & Real & $\begin{array}{l}\text { Boeb } \\
\text { Traures }\end{array}$ & and & Reat & \\
\hline Nalund Ge: & 27 & 24 & 5.1 & 154 & 135 & $\mathbf{z h g}$ & 0.0 & 69 & 69 & 02 & $\mathbf{v . 5}$ & 158 & 183 & 384 & $\$ 67$ \\
\hline Hextrydty & 0.8 & 1.1 & 1.9 & 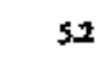 & 6.0 & 112 & $0 s$ & 3.4 & 3.9 & 0.3 & to.0 & 10.3 & 68 & 2015 & 273 \\
\hline Puct oil & 0.0 & 0.0 & 0.0 & 03 & 0.1 & 0.7 & 0.0 & 0.0 & 0.0 & 0.0 & 0.0 & 0.0 & 03 & 0.4 & 0,7 \\
\hline \multicolumn{16}{|l|}{ Katoseace } \\
\hline Propater & 20 & 0.2 & 27 & 1.3 & 1.1 & 24 & 0.0 & 0.0 & 0,0 & a.s & o. o & 0.0 & 33 & 13 & 4.6 \\
\hline Othes Puets & 12 & a. & 12 & 4.8 & 1.6 & 6.4 & 0.0 & 0.0 & 0.0 & 0.0 & 00 & 0.0 & 60 & 16 & 7.6 \\
\hline $\begin{array}{l}\text { Wo licatiog } \\
\text { Fuel Uted }\end{array}$ & 0.0 & 0.0 & 0.0 & 0.7 & 19 & 27 & 0.0 & 03 & 03 & 0.0 & 00 & 0.0 & 0.7 & 23 & 30 \\
\hline $\begin{array}{l}\text { All } \\
\text { Houcebolds }\end{array}$ & 6.7 & 37 & 10.4 & 27.7 & $\boldsymbol{u} .7$ & $S 24$ & os & 106 & 11.1 & as & 25.5 & $\mathbf{x}_{1}$ & 35.4 & 546 & 1000 \\
\hline
\end{tabular}




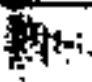

An $\cdots$ s.

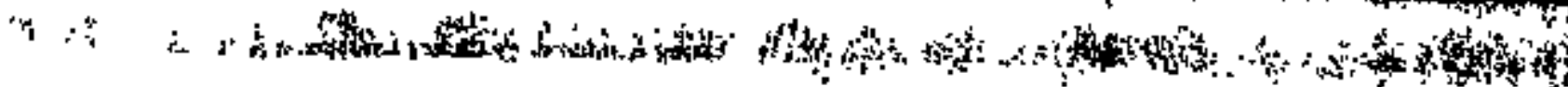

\section{APPENDIX A}

\section{TABLE A-11}

\section{ALL LIHEAP-ELIGIBLE HOUSEHOLDS NATIONAL}

\section{MEAN RESIDENTIAL ENERGY EXPENDITURES IN CURRENT DOUARS}

\begin{tabular}{|c|c|c|c|c|c|c|c|c|c|c|c|c|c|c|c|}
\hline \multirow[b]{3}{*}{$\begin{array}{l}\text { Prinungy } \\
\text { lieutiog } \\
\text { Fod }\end{array}$} & \multicolumn{12}{|c|}{ Honsiles 'Type and Tenure } & & & \multirow[b]{3}{*}{$\begin{array}{l}\text { All } \\
\text { lloute } \\
\text { Foolts }\end{array}$} \\
\hline & \multicolumn{3}{|c|}{ Mobile llome } & \multicolumn{3}{|c|}{ Singte 1'amily } & \multicolumn{3}{|c|}{ Saxall Mulutamily } & \multicolumn{3}{|c|}{ L. Mullatamily } & \multicolumn{2}{|c|}{ A llowing Types } & \\
\hline & Omo & Renl & $\begin{array}{l}\text { Eoth } \\
\text { Toaurs: }\end{array}$ & Oms & Reat & $\begin{array}{l}\text { Doth } \\
\text { Telura }\end{array}$ & Ond & Read & $\begin{array}{l}\text { Dolh } \\
\text { Tenutca }\end{array}$ & Oen & Real & $\begin{array}{l}\text { Both } \\
\text { Tentores }\end{array}$ & Ond & Rend & \\
\hline Natural Gos & $8 \geq 0$ & $m$ & 501 & 1,123 & 1,075 & 1,110 & 1,254 & 906 & 968 & 306 & 609 & 646 & 1,111 & 87 & sA \\
\hline Eectrkiky & 943 & 506 & 860 & $\mathbf{1 , 1 6 3}$ & 909 & 1,094 & 899 & $75 s$ & 764 & 634 & 573 & 524 & 1,004 & (n) & 886 \\
\hline Fuel 에 & $1, \mathbf{X N}$ & 1,372 & 5,501 & 1,358 & 1,430 & 1370 & $1,6 \%$ & 1,143 & 1,318 & $\mathrm{s,0 \textrm {NA }}$ & $7 \propto$ & 74 & 1,388 & $1,1,40$ & 1,246 \\
\hline Kertisepe & $t, 396$ & 690 & 1,082 & 1,066 & 1,381 & 1,256 & $t, 257$ & 0 & 1,257 & 0 & 364 & $36+$ & 1,206 & $t, 116$ & 1,151 \\
\hline Propene & 1,248 & 1008 & 1,210 & 1,2000 & 97 & 1,156 & $t, \pi x$ & 1,673 & 1,687 & 0 & 0 & 0 & 1,211 & 1,049 & 1,134 \\
\hline Other Puets & $\pi 9$ & 938 & 718 & Bg:0 & .964 & $\Leftrightarrow$ & 0 & 0 & 0 & 0 & 0 & $\mathbf{0}$ & B57 & $\$ 64$ & 874 \\
\hline $\begin{array}{l}\text { No liketting } \\
\text { Pued Utood }\end{array}$ & 0 & 0 & 0 & 1,419 & $8 * 7$ & 1,056 & 0 & 1000 & 1,038 & 0 & 0 & 0 & 1,419 & 875 & 1,054 \\
\hline $\begin{array}{l}\text { All } \\
\text { Hounebotide }\end{array}$ & 1,027 & Bo & 978 & 1,129 & 1,069 & 1,15 & 1,362 & 996 & 903 & 665 & 633 & 639 & 1,131 & Bat & 5 \\
\hline
\end{tabular}




\section{APPENDIX A}

TABLE A-12

ALL LIHEAP-ELIGIBLE HOUSEHOLDS

NATIONAL

STANDARD DEVATION OF MEAN EXPENDS. IN CURRENT DOLLARS

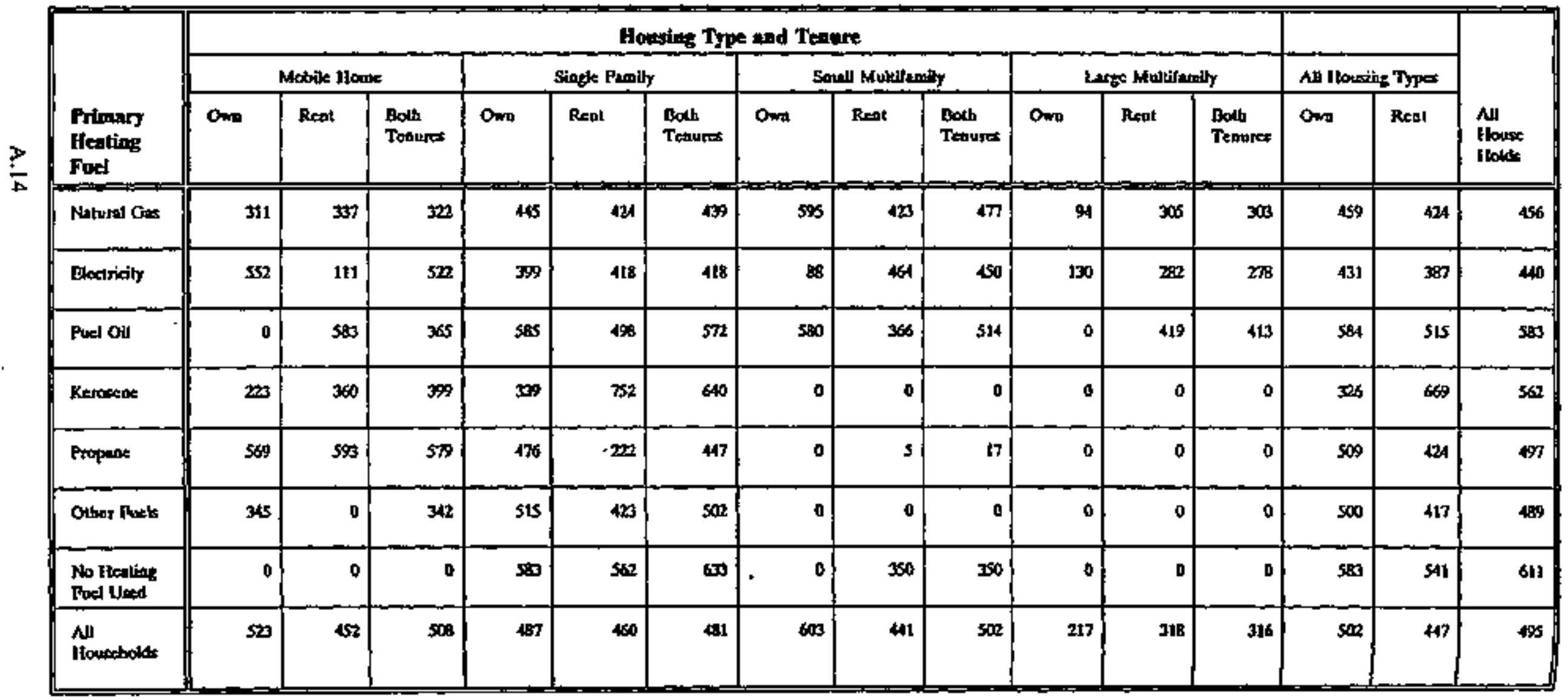


APPENDIX A

TABLE A-13

ALL LIHEAP-ELIGIBLE HOUSEHOLDS REGIONAL / NORTHEAST

MEAN RESIDENTAL. ENERGY EXPENDTIURES IN CURRENT DOLLARS

\begin{tabular}{|c|c|c|c|c|c|c|c|c|c|c|c|c|c|c|c|}
\hline \multirow[b]{3}{*}{$\begin{array}{l}\text { Primary } \\
\text { leating } \\
\text { Foel }\end{array}$} & \multicolumn{12}{|c|}{ Housing Type and Tenare } & & & \multirow[b]{3}{*}{$\begin{array}{l}\text { All } \\
\text { llowse } \\
\text { Iloids }\end{array}$} \\
\hline & \multicolumn{3}{|c|}{ Mobile flome } & \multicolumn{3}{|c|}{ Stapte Pramily } & \multicolumn{3}{|c|}{ Solall Mntitiamby } & \multicolumn{3}{|c|}{ 1sgre Multifamily } & \multicolumn{2}{|c|}{ Ax Itousing Typos } & \\
\hline & Oem & $R \in$ Ret & $\begin{array}{l}\text { Both } \\
\text { Teours: }\end{array}$ & Oma & $R \neq 0$ A & $\begin{array}{l}\text { Boch } \\
\text { Tenurs }\end{array}$ & Omb & Red & $\begin{array}{l}\text { Dow } \\
\text { Teaures }\end{array}$ & Ono & Reat & $\begin{array}{l}\text { Bowh } \\
\text { Tenors }\end{array}$ & Om & Real & \\
\hline Natyrd Gos & 0 & 1,212 & 1,212 & 1,357 & $1 ; 00$ & 1, US & 1,189 & $t, 193$ & 1,192 & 0 & $\infty 20$ & 800 & 1,310 & 1,066 & 1,162 \\
\hline tractricity & 1,068 & 0 & 1,058 & 1,18: & 853 & 1,090 & 842 & 1,308 & 1,29 & $\mathbf{0}$ & 688 & 689 & 1,132 & 84 & 959 \\
\hline Fuet 에 & 0 & 2,044 & 204 & 1,552 & $t, 599$ & 1,560 & $t, 68$ & 1.187 & 1300 & 1, @s & 762 & $n$ & tsso & 1,006 & 1,278 \\
\hline Kerosecox & $1,3 \times 6$ & 1,163 & $1,30 n$ & 0 & 1,200 & 1,23 & 1,27 & 0 & 1,257 & D & 0 & 0 & 1,374 & 1,167 & $t, 292$ \\
\hline Proparoc & 2,177 & 0 & 3.17 & 914 & 0 & 914 & 0 & 0 & 0 & 0 & 0 & 0 & $1, \pi 9$ & 0 & $1, \mathbb{R A}$ \\
\hline Ouker Puets & 0 & $\theta$ & 0 & 1,2286 & 0 & $t, 286$ & 0 & 0 & 0 & 0 & a & 0 & 1,236 & 0 & 1,286 \\
\hline $\begin{array}{l}\text { No Henting } \\
\text { Puet Uterd }\end{array}$ & & & & & & & & & & & & & & & \\
\hline All & 1,564 & $1,2,292$ & 1,469 & 1,428 & 1,361 & 1,4ts & 1,350 & 1,202 & 1,207 & 1,021 & $m$ & 782 & 1,415 & 1,027 & 1,2n1 \\
\hline
\end{tabular}

Source 1990 Residenitul Energy Contumpliton Surmy 


\section{APPENDLX A}

TABLE A-14

ALL LIHEAP-ELJGLBLE HOUSEHOLDS

REGIONAL / NORTHEAST

STANDARD DEVUTTON OF MEAN EXPENDS. IN CURRENT DOLARS

\begin{tabular}{|c|c|c|c|c|c|c|c|c|c|c|c|c|c|c|c|}
\hline \multirow[b]{3}{*}{$\begin{array}{l}\text { Prinany } \\
\text { Heating } \\
\text { Faed }\end{array}$} & \multicolumn{12}{|c|}{ Howsing Type and Tenpire } & & & \multirow[b]{3}{*}{$\begin{array}{l}\text { All } \\
\text { Iboure } \\
\text { Itotids }\end{array}$} \\
\hline & \multicolumn{3}{|c|}{ Mobive llower } & \multicolumn{3}{|c|}{ Single limmily } & \multicolumn{3}{|c|}{ Sautl Modifinmity } & \multicolumn{3}{|c|}{ Lese Mutitamisy } & \multicolumn{2}{|c|}{ All Housing Types } & \\
\hline & Oms & Rest & $\begin{array}{l}\text { Boxh } \\
\text { Tenwess }\end{array}$ & Own & Rear & $\begin{array}{l}\text { Bolb } \\
\text { Teauzes }\end{array}$ & Om & Real & $\begin{array}{l}\text { Bouk } \\
\text { Troures }\end{array}$ & Omin & Reat & $\begin{array}{l}\text { Bolt } \\
\text { Teours }\end{array}$ & Owo & Real & \\
\hline Naturat Gess & 0 & - & 0 & 491 & and & 47 & 199 & 46 & $46 t$ & 0 & 369 & 309 & 199 & 454 & 497 \\
\hline Edectitity & 0 & 0 & 0 & 275 & 298 & 318 & $\mathbf{0}$ & 896 & $\mathbf{8 4 3}$ & 0 & 208 & 228 & 264 & 588 & 520 \\
\hline$J_{\text {rel }}$ OAl & 0 & - & 0 & 656 & 500 & 643 & $\operatorname{sen}$ & $m$ & 533 & (t) & 419 & 413 & 64 & 344 & 657 \\
\hline Keroweac & $m$ & mit & 200 & 0 & 0 & 0 & 0 & o & 0 & 0 & 0 & 0 & 2.12 & 274 & $\mathbf{2 8 9}$ \\
\hline Propase & 296 & 0 & 26 & 0 & 0 & 0 & 0. & 0 & o & 0 & 0 & 0 & $6 n$ & 0 & 638 \\
\hline Ober Juals & 0 & 0 & i) & 600 & 0 & 600 & 0 & 0 & o & 0 & 0 & $\mathbf{0}$ & 600 & 0 & 100 \\
\hline $\begin{array}{l}\text { No lleating } \\
\text { Poel Uned }\end{array}$ & & & & & & & & & & & & & & & \\
\hline Alt & 159 & 395 & 10 & $\operatorname{ses}$ & 458 & 567 & 57 & $\$ 92$ & 52 & 0 & $\operatorname{sen}$ & ma & $5 x$ & $\operatorname{ses}$ & 570 \\
\hline
\end{tabular}


TABLE A-15

\section{ALL LIHEAP-ELIGLBLE HOUSEHOLDS REGIONAL / MHDWEST}

MEAN RESTDENTHL ENERGY EXPENDITURES MY CURRENT DOLARS

\begin{tabular}{|c|c|c|c|c|c|c|c|c|c|c|c|c|c|c|c|}
\hline \multirow[b]{3}{*}{$\begin{array}{l}\text { Primury } \\
\text { Fenting } \\
\text { Fod }\end{array}$} & \multicolumn{12}{|c|}{ Hoasiog Type and Tesure } & & & \multirow[b]{3}{*}{$\begin{array}{l}\text { All } \\
\text { libouse } \\
\text { Holds }\end{array}$} \\
\hline & \multicolumn{3}{|c|}{ Mptivis Iforme } & \multicolumn{3}{|c|}{ Single Pamily } & \multicolumn{3}{|c|}{ Small Muthiramtly } & \multicolumn{3}{|c|}{ 1. Mgethifamity } & \multicolumn{2}{|c|}{ At Ikesing Types } & \\
\hline & own & Reat & $\begin{array}{l}\text { Both } \\
\text { Teoures }\end{array}$ & ams & R\&al & $\begin{array}{l}\text { Bodb } \\
\text { Traurre }\end{array}$ & Omo & Rest & $\begin{array}{l}\text { Boch } \\
\text { Tepourry }\end{array}$ & Ono & Reat & $\begin{array}{l}\text { Botb } \\
\text { Teaufes }\end{array}$ & ONa & Rent & \\
\hline Naleral Gas & $\$$ & $m$ & $90 x$ & 1,162 & 1,209 & 1,186 & 1,652 & $\mathbf{B g 9}$ & 1,012 & $\mathbf{s 3 4}$ & 5,55 & 558 & 1,160 & 933 & $1,0,5$ \\
\hline Electitity & $1, \mathbf{3 4 0}$ & $\mathbf{0}$ & 1,340 & 1,211 & a & 1,211 & 0 & 578 & 578 & 603 & $5 s 5$ & 590 & 1,163 & 567 & $9 \times 8$ \\
\hline Fuel Oil & $\mathbf{0}$ & 0 & 0 & 1,467 & 1563 & 1,469 & 0 & $1,1,19$ & 1,119 & $\mathbf{0}$ & 0 & 0 & 1,467 & 1,295 & 1,40 \\
\hline Kerosene & 0 & 0 & 0 & 0 & 0 & 0 & 0 & 0 & 0 & 0 & 364 & 364 & $\mathbf{0}$ & 364 & 361 \\
\hline Propace & 1,408 & 1,599 & 1,469 & 1,469 & 1,027 & 1,407 & $1, \pi 06$ & 1,573 & 1,607 & 0 & 0 & 0 & 1,156 & $t, 357$ & 1,436 \\
\hline Other Poek & 760 & 938 & $\pi 4$ & $9 \pi$ & 1 & 1,006 & 0 & 0 & 0 & $\mathbf{0}$ & 0 & 0 & 932 & 1,197 & 965 \\
\hline \multicolumn{16}{|l|}{$\begin{array}{l}\text { No fleating } \\
\text { Puet Unost }\end{array}$} \\
\hline $\begin{array}{l}\text { All } \\
\text { Ilouscbolats }\end{array}$ & 1,150 & $1,2,2$ & $t, 170$ & 1,211 & $1,2 \mathrm{~m}$ & 1,217 & 1,474 & 891 & $1,00:$ & 50 & 550 & 555 & 1,293 & 943 & $t, 094$ \\
\hline
\end{tabular}


APPENDIX A

TABLE A-16

ALL LIHEAP-ELIGIBLE HOUSEHOLDS

REGIONAL / MIDWEST

STANDARD DEVATION OF MEAN EXPENDS. IN CURRENT DOLSARS

\begin{tabular}{|c|c|c|c|c|c|c|c|c|c|c|c|c|c|c|c|}
\hline \multirow[b]{3}{*}{$\begin{array}{l}\text { Prtuary } \\
\text { Heating } \\
\text { Soel }\end{array}$} & \multicolumn{12}{|c|}{ Ilongles Type and Teanre } & & & \\
\hline & \multicolumn{3}{|c|}{ Mobite 1lowe } & \multicolumn{3}{|c|}{ Single Pamty } & \multicolumn{3}{|c|}{ Smald Multifamily } & \multicolumn{3}{|c|}{ Lab Multifamily } & \multicolumn{2}{|c|}{ All Elousing Types } & \multirow[b]{2}{*}{$\begin{array}{l}\text { Nl } \\
\text { Houser } \\
\text { t Iolds }\end{array}$} \\
\hline & ONo & Reat & $\begin{array}{l}\text { Bath } \\
\text { Tenuite }\end{array}$ & Omp & $R=\mathbf{A}$ & $\begin{array}{l}\text { Bolh } \\
\text { Tenures }\end{array}$ & Om & Renl & $\begin{array}{l}\text { Boch } \\
\text { Tenutes }\end{array}$ & Ond & Renl & $\begin{array}{l}\text { Bolh } \\
\text { Tenutes }\end{array}$ & Oma & Roat & \\
\hline Natural Ges & 300 & 131 & 259 & 40 & 400 & 436 & 695 & 36: & $\operatorname{sen}$ & 82 & 208 & $\mathbf{2 1}$ & 480 & $4 \$ t$ & 475 \\
\hline Dectridty & 476 & 0 & $4 \mathbf{7}$ & $4 \pm 4$ & 0 & 414 & 0 & 47 & 47 & $14 !$ & 6 & 107 & 499 & 5s & 461 \\
\hline "luel Oil & 0 & 0 & 0 & 386 & 410 & $3 \times 3$ & 0 & 148 & $\$ 48$ & a & $\mathbf{0}$ & 0 & 396 & $m$ & 395 \\
\hline Kercacese & 0 & 0 & 0 & o & 0 & 0 & 0 & 0 & 0 & 0 & 0 & 0 & D & D & 0 \\
\hline Ptoratos & 642 & 534 & $6 * 4$ & 584 & 187 & 567 & 0 & 5 & 17 & 0 & 0 & 0 & s\% & 462 & $5 \pi$ \\
\hline Othet Puets & 510 & 0 & 492 & $5 \%$ & $s t 2$ & 593 & a & 0 & 0 & 0 & 0 & 0 & 587 & 500 & 589 \\
\hline $\begin{array}{l}\text { No Hesting } \\
\text { Pue Used }\end{array}$ & & & & & & & & & & & & & & & \\
\hline $\begin{array}{l}\text { All } \\
\text { Houscbolds }\end{array}$ & $5 n$ & $4 n$ & 55 & sot & 406 & 600 & 667 & 378 & $\operatorname{ses}$ & $\mathbf{1}$ & 214 & $m$ & 527 & 456 & 515 \\
\hline
\end{tabular}


APPENDIX A

\section{TABLE A-17}

\section{ALL LLHEAP-EILIGIBLE HOUSEHOLDS REGIONAL / SOUTH}

\section{MRAN RESIDENTIL ENERGX EXPENDITURES IN CURRENT DOULARS}

\begin{tabular}{|c|c|c|c|c|c|c|c|c|c|c|c|c|c|c|c|}
\hline \multirow[b]{3}{*}{$\begin{array}{l}\text { Priming } \\
\text { Iferting } \\
\text { Fod }\end{array}$} & \multicolumn{12}{|c|}{ Housters Type and Teroure } & & & \multirow[b]{3}{*}{$\begin{array}{l}\text { All } \\
\text { jlowate } \\
\text { jlotsts }\end{array}$} \\
\hline & \multicolumn{3}{|c|}{ Mobik lkome } & \multicolumn{3}{|c|}{ Stape Pamily } & \multicolumn{3}{|c|}{ Small Multitamily } & \multicolumn{3}{|c|}{ Lat Multifully } & \multicolumn{2}{|c|}{ All Housing Tipeo } & \\
\hline & oms & Rest & $\begin{array}{l}\text { Bowh } \\
\text { Tenure }\end{array}$ & Om & Rem & $\begin{array}{l}\text { Both } \\
\text { Tequets }\end{array}$ & Own & Reol & $\begin{array}{l}\text { Both } \\
\text { Tenures }\end{array}$ & Ond & Real & $\begin{array}{l}\text { Bow } \\
\text { Tenures }\end{array}$ & Own & Plet & \\
\hline Natural Gat: & 800 & 62 & 80 & $1,12:$ & 921 & 1,074 & 737 & BH & $3 \mathbf{1}$ & n & 347 & 247 & 1,105 & 821 & $\$ 0$ \\
\hline Dectridbly & 900 & 365 & 847 & 1,155 & 969 & 1,088 & 0 & rax & 78 & 0 & $\cos$ & $\infty 0$ & 1,116 & $m$ & 673 \\
\hline Pised Oil & $1, \pi 4$ & $8 \pi$ & 1.526 & $9 n$ & $1,17 \pi$ & 1,001 & 0 & 955 & 955 & o & v & $\mathbf{0}$ & 1,051 & 1,067 & 1,054 \\
\hline Kercotot & 0 & 7SA & 764 & 8,066 & $1,3 \%$ & 1,258 & 0 & 0 & o & 0 & $\mathbf{0}$ & 0 & 1,066 & 1,170 & 1,137 \\
\hline Propane & 1,199 & 76 & $1,0 \infty \infty$ & 2,074 & 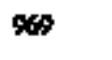 & 1,055 & 0 & 0 & a & 0 & 0 & 0 & 1,107 & 867 & 1,053 \\
\hline Otber Puols & 589 & 0 & 589 & $m$ & $m$ & $m$ & 0 & o & b & B & a & 0 & 361 & $\pi 4$ & 763 \\
\hline $\begin{array}{l}\text { No fleating } \\
\text { j'uel theod }\end{array}$ & 0 & 0 & 0 & $\% 9$ & 0 & 99 & 0 & 0 & 0 & 0 & 0 & 0 & 979 & 0 & 97 \\
\hline All & 1,007 & $m$ & $m s$ & 1,67 & 960 & 1,052 & $m$ & 258 & $m$ & 0 & 655 & 655 & $\$, 071$ & 812 & $5 \$ 8$ \\
\hline
\end{tabular}




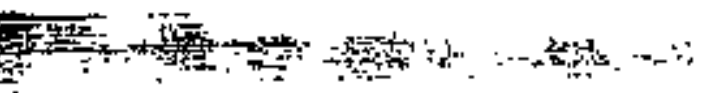

\section{APPENDIX A}

TABLE A-18

\section{ALL LIHEAP-ELIGIBLE HOUSEHOLDS} REGIONAL / SOUTh

\section{STANDARD DEVIATION OF MEAN EXPENDS. IN CURRENT DOLAARS}

\begin{tabular}{|c|c|c|c|c|c|c|c|c|c|c|c|c|c|c|c|}
\hline \multirow[b]{3}{*}{$\begin{array}{l}\text { Primary } \\
\text { Heating } \\
\text { Pod }\end{array}$} & \multicolumn{12}{|c|}{ Hoosting Type and Tenore } & & & \multirow[b]{3}{*}{$\begin{array}{l}\text { Nn } \\
\text { Ilowes } \\
\text { flowht }\end{array}$} \\
\hline & \multicolumn{3}{|c|}{ Mabile flowe } & \multicolumn{3}{|c|}{ Simede Pamily } & \multicolumn{3}{|c|}{ Smenl Multifamity } & \multicolumn{3}{|c|}{ Layg Multilamisty } & \multicolumn{2}{|c|}{ All flousing Types } & \\
\hline & Owo & Reat & $\begin{array}{l}\text { Boeb } \\
\text { Tesures }\end{array}$ & Own & Real & $\begin{array}{l}\text { Botb } \\
\text { Teaures }\end{array}$ & Onn & Rral & $\begin{array}{l}\text { Both } \\
\text { Teoorat }\end{array}$ & Owo & Rent & $\begin{array}{l}\text { Both } \\
\text { Teaures }\end{array}$ & Omn & Reol & \\
\hline Natural Gest & $\mathbf{2 0 2}$ & 219 & * & 417 & 368 & 414 & $\mathbf{s a}$ & 303 & $m$ & $\theta$ & 255 & 255 & 412 & 20 & 406 \\
\hline Eertricity & 343 & D & 540 & 30 & 347 & 381 & 0 & 287 & 387 & 0 & 310 & 310 & 828 & 356 & 126 \\
\hline Ixus oal & 0 & o & 32 & 335 & 301 & 340 & a) & 214 & att & $\mathbf{0}$ & 0 & 0 & 37 & 302 & $\mathbf{3 6 8}$ \\
\hline Xetctede. & 0 & $\mathbf{3 0 m}$ & 307 & 309 & 舟 & 60 & 0 & 0 & 0 & 0 & 0 & 0 & 339 & $\pi 7$ & 631 \\
\hline Propece & 437 & 314 & SE & 353 & 347 & $\$$ & 0 & 0 & 0 & 0 & 0 & $\mathbf{0}$ & 30 & 302 & 378 \\
\hline Other Pots & 4) & 0 & 17 & 387 & 296 & 289 & 0 & 0 & 0 & 0 & 0 & 0 & 294 & 286 & $28 \mathrm{~A}$ \\
\hline $\begin{array}{l}\text { No Jletint } \\
\text { Pued Uteod }\end{array}$ & 0 & 0 & 0 & 0 & 0 & 0 & 0 & 0 & o & $\mathbf{0}$ & 0 & 0 & 0 & 0 & 0 \\
\hline $\begin{array}{l}\text { AI } \\
\text { Houscholds }\end{array}$ & ATI & 294 & 188 & 30 & 21 & 406 & 1aA & 297 & $\$$ & 0 & 300 & 300 & 407 & $3 s$ & \\
\hline
\end{tabular}




\section{APPENDIX A}

TABLE A-19

ALL LIHEAP-ELIGIBLE HOUSEHOLDS

REGIONAL / WEST

MEAN RESIDENT1AL ENERGY EXPENDITURES IN CURRENT DOLARS

\begin{tabular}{|c|c|c|c|c|c|c|c|c|c|c|c|c|c|c|c|}
\hline \multirow[b]{3}{*}{$\begin{array}{l}\text { Primary } \\
\text { Ilentine } \\
\text { Fatel }\end{array}$} & \multicolumn{12}{|c|}{ Hoosing Type and Tenure } & & & \multirow[b]{3}{*}{$\begin{array}{l}\text { Al } \\
\text { llowse } \\
\text { J lokts }\end{array}$} \\
\hline & \multicolumn{3}{|c|}{ Matiat Howe } & \multicolumn{3}{|c|}{ Sloge Pamily } & \multicolumn{3}{|c|}{ Small Multifamily } & \multicolumn{3}{|c|}{ Le Multifmimity } & \multicolumn{2}{|c|}{ All Howing Typer } & \\
\hline & Ome & Rent & $\begin{array}{l}\text { Boile } \\
\text { Teparss }\end{array}$ & Owo & Rsal & $\begin{array}{l}\text { Bow } \\
\text { Tenures }\end{array}$ & Oni & Reat & $\begin{array}{l}\text { Both } \\
\text { Tentras }\end{array}$ & Own & Raal & $\begin{array}{l}\text { Boxh } \\
\text { Tenumse }\end{array}$ & Omn & $R \in$ ot & \\
\hline Nolunat $C_{\infty}$ & 616 & 69 & 60 & (4) & $\$ 4$ & 931 & 0 & 606 & $\cos$ & 394 & $\$ \mathbf{1 7}$ & sis & 800 & $m$ & $\$$ \\
\hline Wectribity & 列 & 581 & $\$ 87$ & BS & B17 & 834 & 837 & 640 & 000 & 554 & 472 & 475 & 810 & 607 & $6 \mathbf{8 8}$ \\
\hline Puet 여 & 0 & 0 & 0 & 63 & $1,3 n$ & 1,111 & $\mathbf{0}$ & 0 & 0 & 0 & 0 & 0 & 64 & $1,3 n$ & 1,111 \\
\hline \multicolumn{16}{|l|}{ Kerviseace } \\
\hline Propane & 829 & $\mathrm{t}, \mathrm{M}$ & 915 & 98 & 993 & 963 & $\mathbf{0}$ & $\mathbf{0}$ & 0 & $\mathbf{0}$ & a & 0 & 893 & 1,060 & $9 \$ 0$ \\
\hline Othee Puels & 204 & 0 & $\pi 4$ & $\mathbf{7}$ & $t, 012$ & $\Delta 0$ & 0 & o & 0 & 0 & $\mathbf{0}$ & 0 & $m$ & 1,012 & $\infty$ \\
\hline 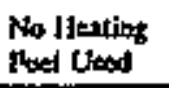 & 0 & 0 & 0 & 1,652 & $\mathbf{B A 3}$ & 1,067 & 0 & 1,1058 & 1,038 & 0 & 0 & 0 & 1,653 & $B 75$ & 1,064 \\
\hline $\mathrm{All}_{\text {J towatholet }}$ & $\Leftrightarrow \mathbf{2}$ & $n 7$ & $\pi s$ & 886 & 99 & 911 & $m$ & 690 & 640 & 487 & StB & 513 & 84 & $\pi$ & 756 \\
\hline
\end{tabular}




\section{APPENDLX A}

TABLE A-20

ALC LIHEAP-ELIGIBLE HOUSEHOLDS REGIONAL / WEST

\section{STANDARD DEVLTION OF MEAN EXPENDS. IN CURRENT DOLLARS}

\begin{tabular}{|c|c|c|c|c|c|c|c|c|c|c|c|c|c|c|c|}
\hline \multirow[b]{3}{*}{$\begin{array}{l}\text { Prtangy } \\
\text { Feating } \\
\text { Fuel }\end{array}$} & \multicolumn{12}{|c|}{ Howilos Type and Teanre } & & & \multirow[b]{3}{*}{$\begin{array}{l}\text { All } \\
\text { llouse } \\
\text { l lolts }\end{array}$} \\
\hline & \multicolumn{3}{|c|}{ Mobile Home } & \multicolumn{3}{|c|}{ Single lamily } & \multicolumn{3}{|c|}{ Sonnll Multifamily } & \multicolumn{3}{|c|}{ Letse Multiamily } & \multicolumn{2}{|c|}{ All Ioustets Types } & \\
\hline & Omn & Rsal & $\begin{array}{l}\text { Both } \\
\text { Teputss }\end{array}$ & Oms & Ptrat & $\begin{array}{l}\text { Bout } \\
\text { Teaure }\end{array}$ & ons & Real & $\begin{array}{l}\text { Botb } \\
\text { Teawses }\end{array}$ & Own & Ropl & $\begin{array}{l}\text { Datb } \\
\text { Trosurs }\end{array}$ & Own & Rent & \\
\hline Naturat Ges: & 291 & $\$ n$ & 336 & $\mathbf{3 4 7}$ & 424 & $\mathbf{s b 8}$ & 0 & 249 & 249 & 0 & 20 & $24 t$ & 353 & 398 & 381 \\
\hline Wectricity & 174 & $n$ & 312 & 364 & $\mathbf{5 1 2}$ & 450 & 108 & 266 & 260 & 0 & 231 & 228 & $\mathbf{m} \mathbf{2}$ & $3 \pi$ & 381 \\
\hline l'wet Oil & 0 & $\mathbf{0}$ & 0 & 0 & 0 & 36 & a & 0 & 0 & $\mathbf{0}$ & 0 & 0 & 0 & 0 & 3 \\
\hline \multicolumn{16}{|l|}{ Kerosetwe } \\
\hline Propane & 215 & 0 & 305 & 116 & J'A & 151 & 0 & 0 & 0 & 0 & 0 & 0 & 19 & 351 & 263 \\
\hline Otber linets & 13 & 0 & 13 & 576 & 37 & s) & 0 & 0 & 0 & 0 & 0 & 0 & 515 & 37 & $4 \%$ \\
\hline $\begin{array}{l}\text { No liconting } \\
\text { Pued Uted }\end{array}$ & 0 & 0 & 0 & 600 & 562 & 67 & 0 & $\mathbf{2 5 0}$ & 350 & 0 & 0 & 0 & 600 & SAt & 609 \\
\hline $\begin{array}{l}\text { All } \\
\text { Hounebolds }\end{array}$ & 289 & $40 t$ & $3 \mathbf{3}$ & $m$ & 156 & 439 & 108 & $2 x$ & 207 & $\mathbf{B 3}$ & 253 & $\mathbf{2 s} 1$ & 40 & 402 & 408 \\
\hline
\end{tabular}


APPENDLX A

TABLE A-21

\section{ALL LJHEAP-ELIGIBLE HOUSEHOLDS NATIONAL}

\section{MEAN ANNUAL CASH INCOME}

\begin{tabular}{|c|c|c|c|c|c|c|c|c|c|c|c|c|c|c|c|}
\hline \multirow[b]{3}{*}{$\begin{array}{l}\text { Priming } \\
\text { Heatirg } \\
\text { Fuel }\end{array}$} & \multicolumn{12}{|c|}{ Housing Type and Tenure } & & & \multirow[b]{3}{*}{$\begin{array}{l}\text { All } \\
\text { Ilouson } \\
\text { I tolds }\end{array}$} \\
\hline & \multicolumn{3}{|c|}{ Mobilo Howe } & \multicolumn{3}{|c|}{ Singde l'moity } & \multicolumn{3}{|c|}{ Small Mullitumily } & \multicolumn{3}{|c|}{ Larte Multilanily } & \multicolumn{2}{|c|}{ All Elomins Type } & \\
\hline & Oma & $\mathbf{R}=\mathbf{n l}$ & $\begin{array}{l}\text { Both } \\
\text { Tesultes }\end{array}$ & Dיw & Redl & $\begin{array}{l}\text { Both } \\
\text { Toouras }\end{array}$ & oms & Rent & $\begin{array}{l}\text { Bolb } \\
\text { Tewores }\end{array}$ & Ono & Rent & $\begin{array}{l}\text { Babl } \\
\text { Teaunct }\end{array}$ & Own & Real & \\
\hline Naloral Ohs & 9,559 & a,7riot & 9,258 & 10,998 & 11,165 & $1 t, 050$ & $10 \cos$ & 8,374 & $\mathrm{a}, 763$ & 9300 & 6,951 & a,959 & 10,867 & 9,541 & 10,160 \\
\hline Destricty & 10,613 & 6,327 & 9,741 & 11,742 & 9580 & 10,902 & $351 t$ & 10,065 & $9,90 \mathrm{~m}$ & 3,44 & 7.916 & 3,126 & 11,335 & 8,701 & 9368 \\
\hline Pust Oil & 2,250 & $10,25 t$ & 9,07 & $11,4 s$ & 12342 & $13,6 n$ & 10196 & R.T2T & 9,419 & 4500 & 6,625 & 6,526 & 11,219 & 8811 & 10,201 \\
\hline Kercecas & 11,656 & 4,908 & 7,468 & 11,24 & 10,606 & 10,913 & 11,750 & 0 & $11, \$ 0$ & 0 & 1,500 & 1,500 & 11,437 & 7,760 & 9,195 \\
\hline Propose & 11,175 & 6,709 & 10,161 & 9,024 & 3,700 & 8,781 & 11,750 & 12,536 & $12 \geq 203$ & 0 & 0 & 0 & 9,758 & 7,436 & 9,275 \\
\hline Other I'octs & 9,159 & 3500 & 2,94 & 12,031 & to,494 & $11, m$ & $\mathbf{0}$ & 0 & $\mathbf{0}$ & 0 & 0 & $\mathbf{0}$ & 11,659 & 10,299 & 11,449 \\
\hline $\begin{array}{l}\text { No Ilenlios } \\
\text { Poel Uned }\end{array}$ & 0 & $\mathbf{a}$ & 0 & $n p \infty$ & 13,94 & $m, 19$ & 0 & $9, \pi$ & $9, \pi 4$ & 0 & 0 & 0 & $2, \sin 3$ & 13,03 & 16,429 \\
\hline $\begin{array}{l}\text { All } \\
\text { Houstbolds }\end{array}$ & 10,399 & 7,199 & 9,409 & 21,149 & $10, n$ & $11,04:$ & 10,521 & 8750 & 9,000 & 7581 & 7,978 & 7,967 & 10,999 & 9,005 & to,jus \\
\hline
\end{tabular}




\section{APPENDIX A}

TABLE A-22

\section{ALL LIHEAP-ELIGIBLE HOUSEHOLDS NATIONAL}

MEAN ENERGY BURDEN - EXPENDITURES AS \% OF INCOME

\begin{tabular}{|c|c|c|c|c|c|c|c|c|c|c|c|c|c|c|c|}
\hline \multirow[b]{3}{*}{$\begin{array}{l}\text { Printary } \\
\text { Heating } \\
\text { Ptuel }\end{array}$} & \multicolumn{12}{|c|}{ Hoosing Type and Tenore } & & & \multirow[b]{3}{*}{$\begin{array}{l}\text { All } \\
\text { Illowe } \\
\text { Illoxids }\end{array}$} \\
\hline & \multicolumn{3}{|c|}{ Mobtle Hoone } & \multicolumn{3}{|c|}{ Single Iamily } & \multicolumn{3}{|c|}{ Sogall Multitumity } & \multicolumn{3}{|c|}{ Large Muldrumity } & \multicolumn{2}{|c|}{ All Housting Types } & \\
\hline & own & Rest & $\begin{array}{l}\text { Bods } \\
\text { Troutes }\end{array}$ & Ont & Ren! & $\begin{array}{l}\text { Both } \\
\text { Tenutes }\end{array}$ & Owa & Rent & $\begin{array}{l}\text { Boxh } \\
\text { Tenufe }\end{array}$ & Own & Real & $\begin{array}{l}\text { Boxh } \\
\text { Tenums }\end{array}$ & Owi & Real & \\
\hline Naturat Chas & 10,4 & 132 & 113 & $13 s$ & L.1 & 14,0 & 152 & 13,0 & 16.7 & 58 & 11.7 & 11.6 & 133 & 14.4 & 13,9 \\
\hline Eledrictity & 27 & 85 & \&.7 & 127 & 265 & 142 & 125 & 129 & 128 & 8.4 & 12.9 & 129 & $1 \pm .9$ & 13.8 & 13,1 \\
\hline Puel Oid & $\mathbf{2 0 , 3}$ & t.3.7 & tB.4 & 16.3 & $\{27$ & 15.7 & 189 & 28.6 & 2ss & 229 & 21.9 & 21.9 & 16.7 & 212 & 18.5 \\
\hline Ketoseno & 277 & 音1 & 30.4 & 10.6 & 173 & 14.6 & to.7 & 0.0 & 10.7 & 0.0 & 243 & 243 & 172 & 227 & 213 \\
\hline Propade & 12.4 & 202 & 149 & 19.2 & $22 \dot{8}$ & 19.9 & 145 & 135 & 13.9 & 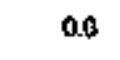 & 0.0 & 0.0 & 173 & 21.4 & 181 \\
\hline Otber Pucks & 28 & $26 B$ & 95 & 9.1 & 10.4 & 9.6 & 0.0 & 0.0 & 0.0 & 0,0 & 0.0 & 0.0 & 9.4 & 10.9 & 96 \\
\hline $\begin{array}{l}\text { No Heating } \\
\text { Pus Uneed }\end{array}$ & 20 & of & 0.0 & 6.7 & 6.3 & 67 & 00 & 11.4 & 11.4 & 0.0 & 0.0 & 0.0 & 67 & 7.4 & 72 \\
\hline $\begin{array}{l}\text { Ait } \\
\text { Joweebolts }\end{array}$ & $\mathbf{t 2 0}$ & 179 & 127 & 138 & כ51 & 142 & $\mathbf{5 . 7}$ & 173 & 17.0 & 104 & 134 & 235 & 137 & 152 & 14.4 \\
\hline
\end{tabular}




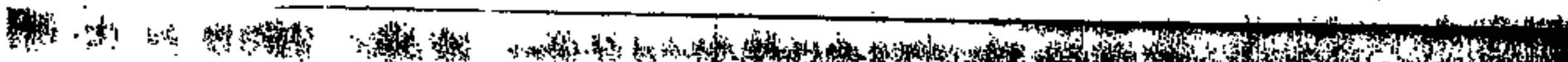

\section{APPENDIX A}

\section{TABLE A-23}

\section{ALL LIHEAP-ELIGIBLE HOUSEHOLDS BY PROGRAM PARTICIPATION NATIONAL}

\section{THOUSANDS OF HOUSEFOLDS}

\begin{tabular}{|c|c|c|c|c|c|c|c|c|c|c|c|c|c|c|c|}
\hline & \multicolumn{12}{|c|}{ 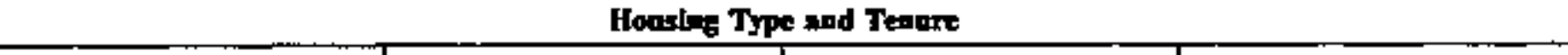 } & & & \multirow[b]{3}{*}{$\begin{array}{l}\text { All } \\
\text { Itouser } \\
\text { Itokds }\end{array}$} \\
\hline & \multicolumn{3}{|c|}{ Mothile lionte } & \multicolumn{3}{|c|}{ Singlo Pamily } & \multicolumn{3}{|c|}{ Stand Mullifumily } & \multicolumn{3}{|c|}{ Levg Multifumily } & \multicolumn{2}{|c|}{ All Itowing Types } & \\
\hline & Om & Renal & $\begin{array}{l}\text { Ropth } \\
\text { Tenurst }\end{array}$ & Omb & Rent & $\begin{array}{l}\text { Dout } \\
\text { Tenure: }\end{array}$ & Omo & Ret & $\begin{array}{l}\text { Botb } \\
\text { Temeres }\end{array}$ & and & Reat & $\begin{array}{l}\text { Oocb } \\
\text { Tenturs }\end{array}$ & Onn & Repl & \\
\hline $\begin{array}{l}\text { Al LHTSP- } \\
\text { Elighte } \\
\text { Itousebouts }\end{array}$ & 1,002 & 674 & $2,27 \pi$ & 11,56 & 4,75 & 16,355 & 694 & $1,2, k$ & 3,938 & 14 & 5,148 & 5,313 & 14,009 & 13854 & $n, p i s$ \\
\hline $\begin{array}{l}\text { AITXC } \\
\text { Rexijiknis }\end{array}$ & 145 & $17 \%$ & 524 & 485 & 202 & 1389 & 0 & 819 & 819 & 0 & $m$ & $m$ & 5 & 2,579 & 3,310 \\
\hline $\begin{array}{l}\text { SSI } \\
\text { Pedipiedts }\end{array}$ & 133 & 93 & 228 & 89 & 31: & 1,230 & 11 & 289 & 300 & 0 & $\operatorname{sen}$ & 380 & 1,0여 3 & 1,290 & 2,30 \\
\hline 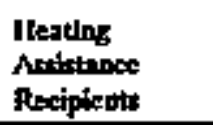 & 529 & 150 & 479 & 1,03 & 939 & $23 \pi$ & 39 & $\$ 5$ & 40 & 0 & $1 \pi$ & $4 n$ & $1,800]$ & 2,000 & 3,801 \\
\hline $\begin{array}{l}\text { Pood Stampe } \\
\text { Recipieots }\end{array}$ & $2 \pi 9$ & 20 & SAt & 1,27 & $15 n$ & $2 \pi$ & 11 & 94 & $95 s$ & IE & 1,274 & 1,293 & 1,534 & 4,051 & 5,516 \\
\hline 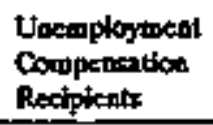 & 130 & 9 & 141 & 500 & 130 & 630 & 8 & 83 & 166 & to & 134 & 150 & $7 \mathrm{TI}$ & 356 & 1,087 \\
\hline $\begin{array}{l}\text { Subcidined } \\
\text { Housing } \\
\text { Rapripients }\end{array}$ & 0 & 92 & 92 & 0 & 3. & 138 & 0 & 434 & 434 & 0 & $\$ 90$ & 590 & 0 & 1,453 & 1,653 \\
\hline
\end{tabular}




\section{APPENDIX A}

TABLE A-2A

\section{ALL LIHEAP-ELIGIBLE HOUSEHOLDS BX PROGRAM PARTICIPATION} NATIONAL

\section{PERCENT OF HOUSEHOLDS}

\begin{tabular}{|c|c|c|c|c|c|c|c|c|c|c|c|c|c|c|c|}
\hline & \multicolumn{12}{|c|}{ Homsing Tye and Tenort } & \multirow{2}{*}{\multicolumn{2}{|c|}{ All llowint Typex }} & \multirow[b]{3}{*}{$\begin{array}{l}\text { Ath } \\
\text { Ilouse } \\
\text { Ilohts }\end{array}$} \\
\hline & \multicolumn{3}{|c|}{ Mobtle Howe } & \multicolumn{3}{|c|}{ Single Premtsy } & \multicolumn{3}{|c|}{ Sogall Medeltantly } & \multicolumn{3}{|c|}{ Largo Multtamity } & & & \\
\hline & Oma & Reat & $\begin{array}{l}\text { Both } \\
\text { Teaures }\end{array}$ & Owo & Rent & $\begin{array}{l}\text { Bout } \\
\text { Teawrat }\end{array}$ & Ont & Rent & $\begin{array}{l}\text { Botb } \\
\text { Teaures }\end{array}$ & Ond & Real & $\begin{array}{l}\text { Both } \\
\text { Tenuess }\end{array}$ & Om & Real & \\
\hline 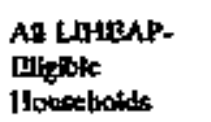 & 5.7 & 24 & 8.2 & 4t. 6 & 17.1 & skt & 25 & 11.6 & 14.1 & os & IBS & 19.1 & 50.3 & 49.7 & tons \\
\hline $\begin{array}{l}\text { ArDC } \\
\text { Reripketts }\end{array}$ & os & 0.6 & 1.2 & 1.7 & 11 & 5.0 & 0.0 & 29 & 29 & 0.0 & $2:$ & 2-5 & 23 & 96 & 11.9 \\
\hline $\begin{array}{l}\text { SSt } \\
\text { Atedipiests }\end{array}$ & 0.5 & 03 & 08 & 32 & 13 & 4.4 & 0.0 & 10 & 1.1 & 0.0 & $2 t$ & 2t & 3.7 & 46 & at \\
\hline $\begin{array}{l}\text { Jlentity } \\
\text { Axtinsoce } \\
\text { Recipients }\end{array}$ & 12 & os & 1.7 & 5.1 & 34 & 85 & 0.1 & 1.6 & $t \cdot B$ & 0,0 & 1.7 & 1.7 & 65 & 73 & 13.7 \\
\hline 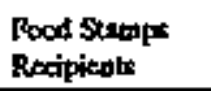 & 1.0 & 0.9 & 1.9 & 4 & 56 & 500 & 00 & 34 & 3.4 & 0.5 & 46 & 16 & 55 & 145 & 200 \\
\hline 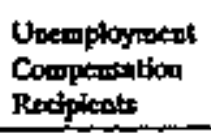 & 0.5 & $\mathbf{0 . 0}$ & s & 18 & 03 & 21 & 03 & 03 & 0.6 & 0.5 & 05 & os & 26 & 13 & 39 \\
\hline $\begin{array}{l}\text { Subcitined } \\
\text { Howesing } \\
\text { Recipinats }\end{array}$ & 0.0 & 03 & 03 & a. & 12 & 12 & a.d & 16 & 16 & D.0 & $2 \mathbf{1}$ & 21 & 0.0 & $s+2$ & $\$ 2$ \\
\hline
\end{tabular}


TABLE A-25

\section{ALL LIHEAP-ELIGIBLE HOUSEHOLDS BY PROGRAM PARTICIPATION NATIONAL}

MOAN RESTDENTIAL ENERGY EXPENDTTURES IN CURRENT DOUARS

\begin{tabular}{|c|c|c|c|c|c|c|c|c|c|c|c|c|c|c|c|}
\hline & \multicolumn{12}{|c|}{ Fongine Type and Tenare } & & & \multirow[b]{3}{*}{$\begin{array}{l}\text { All } \\
\text { Houspo } \\
\text { Hold: }\end{array}$} \\
\hline & \multicolumn{3}{|c|}{ Nobile lfoose } & \multicolumn{3}{|c|}{ Stape Panlly } & \multicolumn{3}{|c|}{ Smand Mullitamily } & \multicolumn{3}{|c|}{ Lete Multtramily } & \multicolumn{2}{|c|}{ All Houstex Typer } & \\
\hline & Own & Renl & $\begin{array}{l}\text { Dotb } \\
\text { Tequrs }\end{array}$ & Owa & Rent & $\begin{array}{l}\text { Both } \\
\text { Tenutes }\end{array}$ & Own & Reat & $\begin{array}{l}\text { Both } \\
\text { Teautes }\end{array}$ & Onis & Peat & $\begin{array}{l}\text { Both } \\
\text { Tenutes }\end{array}$ & Ont & Fend & \\
\hline $\begin{array}{l}\text { AH UHEIDAP } \\
\text { Eligible } \\
\text { Alouselyolds }\end{array}$ & $1,02 ?$ & 860 & $9 \pi$ & 1,139 & $t, 059$ & $1, t 5$ & 1,312 & pros & 903 & 605 & 633 & 634 & 1,131 & 854 & 991 \\
\hline $\begin{array}{l}\text { Albc } \\
\text { Recipicats }\end{array}$ & 1,045 & 4,010 & $\$, 041$ & 1,209 & 1,130 & 1,169 & 0 & 1,014 & 1,034 & 0 & $\pi a$ & $m$ & 1,194 & $m_{1}$ & 1,013 \\
\hline $\begin{array}{l}\text { SSI } \\
\text { Recipteats }\end{array}$ & 832 & 918 & 267 & 99 & 827 & ses & $5 s 3$ & $\operatorname{sen}$ & 871 & $\mathbf{0}$ & 356 & s56 & 967 & $m 2$ & 81 \\
\hline $\begin{array}{l}\text { Ileatin: } \\
\text { Anstations } \\
\text { Reripicalts }\end{array}$ & 97 & 986 & 987 & 963 & 1,105 & 1,019 & 2,750 & 1,04 & 1,146 & 0 & 768 & 768 & 997 & 1,003 & 1,000 \\
\hline $\begin{array}{l}\text { Rood Scampe } \\
\text { Recipientr }\end{array}$ & $t, 0 s t$ & $1,0 m$ & 1,065 & 2,056 & 1,$00 ; 9$ & 1,069 & $\$ 3$ & 978 & 973 & $\$ 50$ & 314 & 312 & $1,0 m$ & 92 & sa \\
\hline $\begin{array}{l}\text { Unempiojued } \\
\text { Compentition } \\
\text { Retipienis }\end{array}$ & 1,106 & 404 & 1,058 & 1,174 & 1,0es & 3,186 & 1,552 & 1,295 & 1,474 & 34 & 623 & 616 & 1,200 & 942 & 1,119 \\
\hline $\begin{array}{l}\text { Subsidired } \\
\text { Ilousing } \\
\text { flupipiests }\end{array}$ & 0 & 966 & 986 & 0 & 1,02 & 1,032 & 0 & 1,057 & 1,079 & 0 & $75 z$ & 752 & 0 & 929 & 20 \\
\hline
\end{tabular}




\section{APPENDIX A}

\section{TABLE A-26}

\section{ALL LHEAP-ELIGIBLE HOUSEHOLDS BY PROGRAM PARTICIPATION NATIONAL}

MEAN ENERGY EURDEN - EXPENDTUUES AS \% OF INCOME

\begin{tabular}{|c|c|c|c|c|c|c|c|c|c|c|c|c|c|c|c|}
\hline & \multicolumn{12}{|c|}{ Hanslas Type and Tenore } & & & \multirow[b]{3}{*}{$\begin{array}{l}\text { Ni } \\
\text { Hounse } \\
\text { llokts }\end{array}$} \\
\hline & \multicolumn{3}{|c|}{ Matble Howe } & \multicolumn{3}{|c|}{ Single Pamily } & \multicolumn{3}{|c|}{ Sctantl Multifiantity } & \multicolumn{3}{|c|}{ Cange Motiliamily } & \multicolumn{2}{|c|}{ All I fousing Types } & \\
\hline & Own & Rear & $\begin{array}{l}\text { Both } \\
\text { Tedurs }\end{array}$ & Owi & Rezat & $\begin{array}{l}\text { Bodh } \\
\text { Thapirs }\end{array}$ & Owre & $R=n t$ & $\begin{array}{l}\text { Bout } \\
\text { Tambras }\end{array}$ & Own & Rent & $\begin{array}{l}\text { Borh } \\
\text { Tepures }\end{array}$ & Ons & Rest & \\
\hline $\begin{array}{l}\text { All InIDAP. } \\
\text { Bigithe } \\
\text { ILouseboids }\end{array}$ & 12 & 18 & 14 & 14 & - 15 & 14 & 16 & 17 & 17 & 10 & 13 & 13 & 14 & ss & 14 \\
\hline $\begin{array}{l}\text { NrDC } \\
\text { Recipicols }\end{array}$ & 26 & 20 & 22 & 16 & $\mathbf{2 6}$ & $\mathbf{n}$ & 0 & $\mathbf{n}$ & 20 & 0 & ts & 18 & 18 & $n$ & $z$ \\
\hline SS1 & $\mathbf{E}$ & 15 & 15 & 16 & 17 & 17 & $n$ & 16 & 17 & 0 & 13 & 13 & 16 & b & 16 \\
\hline 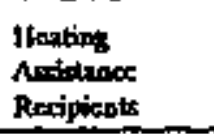 & 16 & $\mathbf{n}$ & 18 & $\boldsymbol{t r}$ & 23 & 19 & 22 & 57 & $\mathfrak{t \top}$ & 0 & 20 & 20 & 17 & 21 & 19 \\
\hline $\begin{array}{l}\text { Rood Stamps } \\
\text { Recopienots }\end{array}$ & 17 & 25 & 19 & 18 & n & $\mathbf{2 0}$ & 37 & 24 & 24 & $s$ & 18 & IB & 18 & 21 & 20 \\
\hline 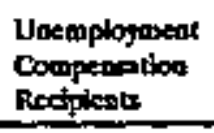 & $\mathbf{s}$ & 4 & $\mathrm{a}$ & t1 & 7 & 10 & t6 & 10 & 13 & $\mathbf{B}$ & 13 & 13 & 11 & 10 & 11 \\
\hline 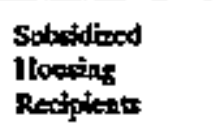 & 0 & 19 & 19 & 0 & 20 & $\boldsymbol{z}$ & 0 & 20 & 20 & 0 & 16 & 16 & 0 & 19 & 19 \\
\hline
\end{tabular}




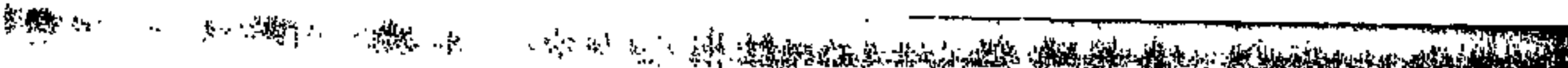

APPENDIX A

TABLE A-27

ALL LHEAP-ELIGIBLE HOUSEHOLDS BY DEMOGRAPHC CHARACTERISTICS

NATIONAL

THOUSANDS OF HOUSEHOLDS

\begin{tabular}{|c|c|c|c|c|c|c|c|c|c|c|c|c|c|c|c|}
\hline & \multicolumn{12}{|c|}{ Eonsles Type and Tenure } & & & \multirow[b]{3}{*}{$\begin{array}{l}\text { All } \\
\text { Ilousen } \\
\text { Ilonlss }\end{array}$} \\
\hline & \multicolumn{3}{|c|}{ Motik Home } & \multicolumn{3}{|c|}{ Stopdo Family } & \multicolumn{3}{|c|}{ soned Multanily } & \multicolumn{3}{|c|}{ Lete Musumbly } & \multicolumn{2}{|c|}{ Al llowesing Type } & \\
\hline & Oma & Rent & $\begin{array}{l}\text { Bots } \\
\text { Tepores }\end{array}$ & Oms & Real & $\begin{array}{l}\text { Doeb } \\
\text { Traurts }\end{array}$ & Onn & Real & $\begin{array}{l}\text { Both } \\
\text { Teoures }\end{array}$ & own & R*tat & $\begin{array}{l}\text { Both } \\
\text { Teputes }\end{array}$ & Own & Ptot & \\
\hline $\begin{array}{l}\text { All tnteNP- } \\
\text { Elighble } \\
\text { tlouecholds }\end{array}$ & 1,500 & 674 & $1, m$ & 11,50 & 4,767 & 14,355 & 694 & $3,2 k$ & 3,938 & 144 & 5,168 & 5,313 & 14,029 & 13,854 & 27,683 \\
\hline $\begin{array}{l}\text { Jowebolids } \\
\text { mith Dderh } \\
\text { Meorber }\end{array}$ & $\sin$ & 52 & 500 & 7536 & 1,013 & 8S59 & 44 & 746 & 1,129 & 68 & 1,798 & 1866 & $85 \%$ & 3,600 & 12,194 \\
\hline $\begin{array}{l}\text { 1Housebolds } \\
\text { milb Cilddrat }\end{array}$ & 812 & 49 & 1,260 & 3,706 & 3,209 & 6,938 & $\$ 11$ & 1,806 & $1,9 m$ & 36 & 1,805 & JBA1 & 1,670 & 7289 & 11,959 \\
\hline $\begin{array}{l}\text { Single-Pireat } \\
\text { Housebolds }\end{array}$ & zs & $m$ & 129 & 1,480 & 1,301 & 2,781 & $\mathbf{3 0}$ & 1,15 & 1,145 & 36 & 1,148 & 1,184 & 1,802 & $3,7 m$ & 5,539 \\
\hline $\begin{array}{l}\text { Atical- } \\
\text { American } \\
\text { tlouscholdes }\end{array}$ & 127 & 119 & 243 & 1,407 & 1,04 & 2,41 & 179 & 92 & 1,101 & 90 & 1,319 & 1,368 & 1,34 & 3,404 & 5,148 \\
\hline $\begin{array}{l}\text { Illoppele } \\
\text { llousebiolds }\end{array}$ & 27 & 114 & 141 & en? & $m$ & 1,54 & 62 & 379 & $M 1$ & 0 & 659 & 69 & 935 & 1,878 & 2844 \\
\hline $\begin{array}{l}\text { Whitt } \\
\text { Howathalest }\end{array}$ & 1,446 & 536 & $1,9 \pi$ & 9,953 & 3,413 & 13367 & 514 & 2,14 & 2,659 & 115 & 3,631 & 3,746 & 12,026 & 9,714 & 21,711 \\
\hline
\end{tabular}

Sourcei 1990 Residentinl Energ Cantranpiton Surwey 


\section{APPENDIX A}

TABLE A-28

\section{ALL LIHEAP-ELIGIBLE HOUSEHOLDS BY DEMOGRAPHIC CHARACTERISTICS} NATIONAL

\section{PERCENT OF HOUSEHOLDS}

\begin{tabular}{|c|c|c|c|c|c|c|c|c|c|c|c|c|c|c|c|}
\hline & \multicolumn{12}{|c|}{ Moasinas Type and Tenare } & & & \\
\hline & \multicolumn{3}{|c|}{ Mobile Hoone } & \multicolumn{3}{|c|}{ Single Pamily } & \multicolumn{3}{|c|}{ Small Multifamily } & \multicolumn{3}{|c|}{ 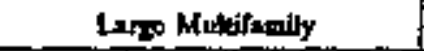 } & \multicolumn{2}{|c|}{ All tousting Types } & \multirow[b]{2}{*}{$\begin{array}{l}\text { Ait } \\
\text { tlowse } \\
\text { llowts }\end{array}$} \\
\hline & OND & Reor & $\begin{array}{l}\text { Bolb } \\
\text { Tearites }\end{array}$ & Omo & Real & $\begin{array}{l}\text { Both } \\
\text { Tenurs }\end{array}$ & Ond & Rest & $\begin{array}{l}\text { Both } \\
\text { Tenures }\end{array}$ & Own & Redt & $\begin{array}{l}\text { Both } \\
\text { Tesures }\end{array}$ & Owd & Rent & \\
\hline 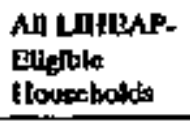 & 5,7 & 24 & Bב & 41.6 & st.1 & 587 & 25 & 91,6 & 14,1 & ns & LE.S & 19.1 & 503 & 49.7 & 100.1 \\
\hline $\begin{array}{l}\text { Jlousebolds } \\
\text { wilh Ederty } \\
\text { Members }\end{array}$ & 1.9 & 03 & 2.1 & 27,0 & 16 & 30.7 & 1.6 & 27 & 43 & 0.2 & 64 & 67 & $30 . \mathrm{B}$ & 129 & 43.7 \\
\hline $\begin{array}{l}\text { Ilowsebolds } \\
\text { wilt Cuildrek }\end{array}$ & 29 & 18 & 1.5 & 133 & 11.6 & 24.9 & $0 x$ & 65 & 6.9 & 0.1 & 65 & 6.6 & 16.3 & 26.1 & 429 \\
\hline $\begin{array}{l}\text { Sintel-Partat } \\
\text { Ilousebolds }\end{array}$ & 0.9 & 0.6 & is & 53 & 4.7 & 10.0 & 0.1 & 4.0 & t.I & a. & 4.1 & 12 & 63 & 23.4 & 19.9 \\
\hline 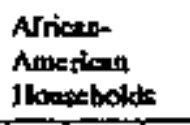 & as & at & 0.9 & so & 37 & ad & 0.6 & 33 & 39 & 0.1 & 4.7 & 18 & 6.3 & 127 & 18.5 \\
\hline $\begin{array}{l}\text { 1lippanic } \\
\text { Ilowebolds }\end{array}$ & A.1 & a.t & 0.5 & 30 & 26 & 5.6 & 02 & 1.4 & 1.6 & 0.0 & 24 & 24 & $\mathbf{3 . 4}$ & 6.7 & 10.1 \\
\hline $\begin{array}{l}\text { While } \\
\text { Jiousenolds }\end{array}$ & $\$ 2$ & 1.7 & 7.1 & $\mathbf{x} .7$ & 127 & $\$ 7.9$ & 18 & 7.7 & 95 & 0.4 & 130 & 134 & 4t.1 & 348 & $7 \mathrm{AlO}$ \\
\hline
\end{tabular}




\section{APPENDEX A}

TABLE A-29

ALL LIHEAP-ELGIBLE HOUSEHOLDS BY DEMOGRAPHIC CHARACTERISTICS NATIONAL

MRAN RESIDENTAL ENERGY EXPENDITURES IN CURRENT DOUARS

\begin{tabular}{|c|c|c|c|c|c|c|c|c|c|c|c|c|c|c|c|}
\hline & \multicolumn{12}{|c|}{ Eowing 'Type and Teoure } & & & \multirow[b]{3}{*}{$\begin{array}{l}\text { All } \\
\text { flowese } \\
\text { Haids }\end{array}$} \\
\hline & \multicolumn{3}{|c|}{ Moble Home } & \multicolumn{3}{|c|}{ Stuge Humily } & \multicolumn{3}{|c|}{ Sonall Mulifumily } & \multicolumn{3}{|c|}{ Lase Molitsmily } & \multicolumn{2}{|c|}{ All liowing Types } & \\
\hline & Own & Rent & $\begin{array}{l}\text { Eols } \\
\text { Tequits }\end{array}$ & Own & Pent & $\begin{array}{l}\text { Both } \\
\text { Teauss }\end{array}$ & Ono & Peat & $\begin{array}{l}\text { Loth } \\
\text { Tcaure: }\end{array}$ & Own & $R \cos x$ & $\begin{array}{l}\text { Both } \\
\text { Tenures }\end{array}$ & Own & Reol & \\
\hline 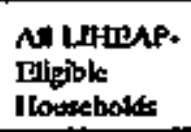 & $1, \infty 2 n$ & 860 & 978 & t,139 & $1,0 \infty$ & 1,115 & 1,34 & 906 & \% & 665 & 603 & 634 & 1,131 & 854 & 994 \\
\hline $\begin{array}{l}\text { Itousetholds } \\
\text { mith Ederty } \\
\text { Meonbels }\end{array}$ & 923 & 463 & B82 & 1,110 & भ1 & 1,000 & $1,2 m$ & 791 & 946 & 639 & s52 & sss & 1,078 & $\pi 9$ & 94 \\
\hline $\begin{array}{l}\text { Hlouretolds } \\
\text { with Chilutiten }\end{array}$ & 1,300 & 935 & 1,170 & 1,209 & 1,129 & 1,215 & 1,515 & $1,0 m$ & 1,053 & s.01 & $m$ & $m$ & 1,291 & 1,000 & 1,116 \\
\hline $\begin{array}{l}\text { Single-Pyedel } \\
\text { Hlowerciolds }\end{array}$ & 1,204 & BN4 & 1,070 & 1,37 & 1,158 & 1,211 & 1,188 & 1, 150 & J,169 & so1 & 749 & 742 & 1,247 & 928 & $1,0<8$ \\
\hline $\begin{array}{l}\text { Afiban. } \\
\text { Amberlon } \\
\text { Itousebolds }\end{array}$ & 1,179 & 1,077 & 1,127 & 1,247 & 1,24 & 1,246 & 1,767 & 1,966 & 1,481 & 1,024 & $\pi 4$ & 721 & 1,292 & ses & 1,069 \\
\hline $\begin{array}{l}\text { Ittrpanic } \\
\text { Ilousebolds }\end{array}$ & 316 & 643 & 676 & 951 & 946 & 9919 & $1, n s$ & 859 & 97 & $\mathbf{0}$ & 678 & 678 & 1,002 & 816 & 878 \\
\hline $\begin{array}{l}\text { Whitc } \\
\text { 1lowesholdk }\end{array}$ & 1,021 & 800 & 971 & 1,123 & 1,009 & 1,097 & 1,199 & $\mathbf{B 1}$ & 900 & 572 & 614 & 613 & 1,112 & 815 & 97 \\
\hline
\end{tabular}




\section{APPENDIX A}

TABLE A-30

ALL LHEAP-ELIGIBLE HOUSEHOLDS BY DEMOGRAPHIC CHARACIERSTICS NATIONAL

MEAN ENERGY BURDEN - EXPEXDITURES AS 5 OF INCOME

\begin{tabular}{|c|c|c|c|c|c|c|c|c|c|c|c|c|c|c|c|}
\hline & \multicolumn{12}{|c|}{ Hoosing Type and Tenure } & & & \multirow[b]{3}{*}{$\begin{array}{l}\text { All } \\
\text { 1]puser } \\
\text { 1lads }\end{array}$} \\
\hline & \multicolumn{3}{|c|}{ Mohile llowe } & \multicolumn{3}{|c|}{ Stapje Family } & \multicolumn{3}{|c|}{ Small Multilanily } & \multicolumn{3}{|c|}{ Large Mulufimity } & \multicolumn{2}{|c|}{ All skousing Type: } & \\
\hline & and & Rool & $\begin{array}{l}\text { Roth } \\
\text { Teburex }\end{array}$ & Om & Renl & $\begin{array}{l}\text { Both } \\
\text { Tequere }\end{array}$ & Omn & Reat & $\begin{array}{l}\text { Botb } \\
\text { Teaurts }\end{array}$ & Own & Reat & $\begin{array}{l}\text { Both } \\
\text { Treours }\end{array}$ & Ownt & Rest & \\
\hline 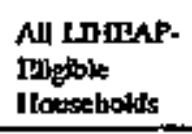 & 12 & 18 & 14 & 14 & is & 14 & t6 & 17 & 17 & to & 13 & 13 & 14 & w & 14 \\
\hline $\begin{array}{l}\text { Iloutacebolds } \\
\text { wilh Điderity } \\
\text { Mewibers }\end{array}$ & t1 & B & $\mathbf{1 t}$ & 15 & is & 15 & is & 12 & $\mathbf{3}$ & 9 & 9 & 9 & 15 & 12 & 14 \\
\hline 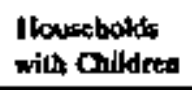 & 13 & 1B & $\mathbf{v}$ & 10 & 14 & 12 & $\$ 1$ & $m$ & 19 & 1 & $\mathbf{w}$ & is & 11 & 16 & su \\
\hline $\begin{array}{l}\text { Singlo-Burol } \\
\text { Itousebolus }\end{array}$ & 17 & 39 & 18 & 14 & $\mathbf{n}$ & 16 & 30 & $\mathbf{2}$ & $n$ & 4 & 19 & 19 & 14 & 20 & 18 \\
\hline 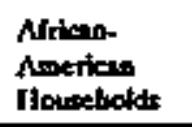 & 14 & $3 \mathbf{s}$ & $\mathbf{2 t}$ & 15 & $\mathbf{m}$ & 17 & $\mathbf{3}$ & 25 & 25 & $\boldsymbol{x}$ & 16 & 16 & 16 & 20 & 19 \\
\hline 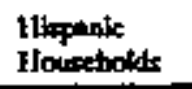 & $s$ & 12 & 11 & $\mathbf{t}$ & 1! & 12 & 13 & 18 & 18 & 0 & $\mathbf{s}$ & 1s & 12 & $\mathbf{H}$ & 13 \\
\hline $\begin{array}{l}\text { White } \\
\text { Itourcholdr }\end{array}$ & 12 & 15 & $\mathbf{6 3}$ & 14 & 15 & 14 & 13 & 14 & 14 & 7 & 13 & $\mathbf{1 3}$ & 13 & 14 & 14 \\
\hline
\end{tabular}




\section{APPENDEX A}

TABLE B-1

\section{ALL LHHEAP-ELIGBLE, HGH-EXPENDITURE HOUSEHOLDS} NATIONAL

\section{THOUSANDS OF hOUSEHOLIS}

\begin{tabular}{|c|c|c|c|c|c|c|c|c|c|c|c|c|c|c|c|}
\hline \multirow[b]{3}{*}{$\begin{array}{l}\text { Prinury } \\
\text { Fenting } \\
\text { Fuel }\end{array}$} & \multicolumn{12}{|c|}{ Elooslos Type and Tenure } & & & \multirow[b]{3}{*}{$\begin{array}{l}\text { All } \\
\text { Howent } \\
\text { Holts }\end{array}$} \\
\hline & \multicolumn{3}{|c|}{ Mobile Howe } & \multicolumn{3}{|c|}{ Sinde Fumily } & \multicolumn{3}{|c|}{ 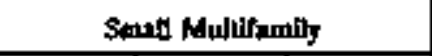 } & \multicolumn{3}{|c|}{ La/gr Maltifyomily } & \multicolumn{2}{|c|}{ All Iboudog Types } & \\
\hline & Own & Real & $\begin{array}{l}\text { Dooth } \\
\text { Tooures }\end{array}$ & OND & Rent & $\begin{array}{l}\text { Tooth } \\
\text { Tenulres }\end{array}$ & Ond & Reat & $\begin{array}{l}\text { Joth } \\
\text { l'egurs }\end{array}$ & Own & Real & $\begin{array}{l}\text { Dooth } \\
\text { TFoures }\end{array}$ & Ond & Rent & \\
\hline Naitral Gat & 94 & 129 & $m$ & 668 & $\$ 92$ & 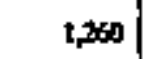 & 133 & 176 & 609 & 0 & 288 & 35: & $8 \%$ & 1,05 & 2,750 \\
\hline Exectidety & Bt & $\mathbf{s}$ & 138 & 20 & 245 & 465 & 10 & 168 & 178 & $\mathbf{0}$ & 152 & 152 & 314 & 619 & 983 \\
\hline Puel Oil & 41 & 9 & 50 & 201 & 62 & 202 & 10 & $\$ 43$ & 53 & $\mathbf{0}$ & st & 97 & $\mathbf{z i}$ & $31 !$ & 568 \\
\hline Kerosene & 19 & 11 & 90 & 58 & 91 & 49 & 0 & 0 & 0 & o & 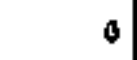 & 0 & $10 ?$ & 132 & 20 \\
\hline Propano & 58 & 69 & 427 & 363 & ș & 42 & 0 & 17 & 17 & 0 & 0 & 0 & not & 165 & e66 \\
\hline Otber Puxts & 31 & 0 & 3 & 0 & .0 & 0 & 0 & 0 & 0 & o & 0 & 0 & 31 & 0 & 31 \\
\hline \multicolumn{16}{|l|}{$\begin{array}{l}\text { No Iftativg } \\
\text { Puel Used }\end{array}$} \\
\hline $\begin{array}{l}\text { All } \\
\text { Hourebolds }\end{array}$ & 67 & 321 & 958 & $t, 5 t 0$ & $1,0 \leqslant 9$ & 259 & 152 & BOA & 956 & 0 & sot & 507 & 209 & 2,689 & 400 \\
\hline
\end{tabular}




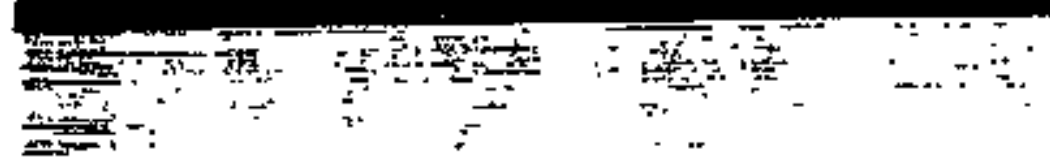

\section{APPENDDX A}

TABLE B-2

ALL LATEAP-ELIGIBLE, HIGH-EXPENDITURE, HOUSEHOLDS

NATIONAL

\section{PERCENT OF HOUSEHOLPS}

\begin{tabular}{|c|c|c|c|c|c|c|c|c|c|c|c|c|c|c|c|}
\hline \multirow[b]{3}{*}{$\begin{array}{l}\text { Priming } \\
\text { Heating } \\
\text { Ped }\end{array}$} & \multicolumn{12}{|c|}{ Hoosing Type and Tonure } & & & \multirow[b]{3}{*}{$\begin{array}{l}\text { All } \\
\text { IIOnece } \\
\text { Itollse }\end{array}$} \\
\hline & \multicolumn{3}{|c|}{ Mobise Home } & \multicolumn{3}{|c|}{ Stangle Pasolly } & \multicolumn{3}{|c|}{ Somall Motsifamithy } & \multicolumn{3}{|c|}{ Lesce Multifimity } & \multicolumn{2}{|c|}{ All Ifousing Types } & \\
\hline & Ond & Rent & $\begin{array}{l}\text { Botb } \\
\text { Tcourss }\end{array}$ & Own & Renl & $\begin{array}{l}\text { Booth } \\
\text { Tepures }\end{array}$ & Owr & Rent & $\begin{array}{l}\text { Both } \\
\text { Tenures }\end{array}$ & Ong & Alsol & $\begin{array}{l}\text { Both } \\
\text { Teaures }\end{array}$ & Owa & Pent & \\
\hline Netural Ges & 1.9 & 26 & 45 & 134 & 11.9 & 253 & 27 & 96 & 13.2 & 0.0 & 52 & 52 & 180 & $\$ 2$ & 472 \\
\hline Dectricity & 1.7 & $1+1$ & 28 & 4.4 & 19 & 9.3 & 02 & 3.4 & 36 & 0.0 & 30 & 3.0 & 6.3 & 124 & 18.7 \\
\hline Foct of & 08 & 0.2 & 1.0 & 4.0 & 13 & 5.3 & 02 & 29 & 3.1 & 0.0 & 20 & 20 & S.j & 62 & 113 \\
\hline Kerocene & 1.0 & 08 & $1 \mathrm{~A}$ & $\$ .2$ & $1 \mathrm{~A}$ & 3.0 & $\infty 0$ & 0.0 & 00 & 0.0 & 0.0 & 0.0 & 2.1 & 27 & 18 \\
\hline 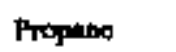 & 69 & 18 & 86 & 73 & 12 & 85 & 0.0 & 0.3 & 03 & 0.0 & 0,0 & 0.0 & 14.1 & 33 & 17.4 \\
\hline Dther Puets & 0.6 & 0.0 & 0.6 & 0,0 & $\infty$ & 0,0 & 0.0 & 0.0 & ano & 0.0 & 0.0 & 0.0 & 0.6 & o. & 0.6 \\
\hline \multicolumn{16}{|l|}{$\begin{array}{l}\text { No Ileating } \\
\text { Poel Uned }\end{array}$} \\
\hline All & 128 & 65 & 192 & 303 & 21.1 & SL. & 3.1 & 16.1 & 192 & 0.0 & 10.2 & 10.2 & 162 & 53.8 & $\tan 0$ \\
\hline
\end{tabular}


मn, ...

\begin{tabular}{|c|c|c|c|c|c|c|c|c|c|c|c|c|c|c|c|}
\hline \multicolumn{16}{|c|}{ APPENDIX A } \\
\hline \multicolumn{16}{|c|}{ TABLE B-3 } \\
\hline \multicolumn{16}{|c|}{$\begin{array}{l}\text { ALL LIHEAP-ELIGIBLE, HIGH-EXPENDITURE HOUSEHOLDS } \\
\text { REGIONAL / NORTHEAST }\end{array}$} \\
\hline \multirow[b]{3}{*}{$\begin{array}{l}\text { Prinary } \\
\text { lientings } \\
\text { Fued }\end{array}$} & \multicolumn{14}{|c|}{ Housling Type aed Tenure } & \multirow[b]{3}{*}{$\begin{array}{l}\text { All } \\
\text { House } \\
\text { Hotdr }\end{array}$} \\
\hline & \multicolumn{3}{|c|}{ Mobile tione } & \multicolumn{3}{|c|}{ Stape Pimily } & \multicolumn{3}{|c|}{ Somall Mutbifamily } & \multicolumn{3}{|c|}{ Late Nuldiranily } & \multicolumn{2}{|c|}{ All Fousing Tys } & \\
\hline & $O m$ & Rent & $\begin{array}{l}\text { Both } \\
\text { Tenurrs }\end{array}$ & Own & Rent & $\begin{array}{l}\text { Booth } \\
\text { Teodics }\end{array}$ & Ome & Rent & $\begin{array}{l}\text { Bolh } \\
\text { Tenords }\end{array}$ & Omn & Rent & $\begin{array}{l}\text { Boxth } \\
\text { Teacers }\end{array}$ & Omp & Rent & \\
\hline Nolural Gex & 0 & 17 & 17 & $M$ & 2 & 101 & So & 119 & 175 & 0 & Bs & 8 & 135 & 247 & 32 \\
\hline Bectriaity & - & a & $\mathbf{0}$ & o & 1s & 15 & 0 & 61 & 61 & 0 & 47 & 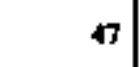 & a & 123 & 123 \\
\hline Fuel Ov & 0 & 9 & 9 & $\pi$ & $n$ & $10]$ & 10 & s & 92 & 0 & 97 & 97 & 89 & 210 & 299 \\
\hline Keftecent & 49 & $\mathbf{z}$ & 71 & a & 0 & 0 & 0 & 0 & o & 0 & 0 & 0 & 49 & $\mathbf{n}$ & $n$ \\
\hline Propace & $\mathbf{3}$ & 0 & $\mathbf{s}$ & d & 0 & 0 & 0 & 0 & 0 & 0 & 0 & 0 & 35 & a & 35 \\
\hline Other Juek & & & & & . & & & & & & & & & & \\
\hline $\begin{array}{l}\text { No Hentints } \\
\text { Fuet Used }\end{array}$ & & & & & & & & & & & & & & & \\
\hline $\begin{array}{l}\text { All } \\
\text { Jlortebolds }\end{array}$ & 4 & 48 & $1 *$ & 158 & 59 & 217 & 66 & $2 \pi$ & 520 & 0 & 234 & $\mathbf{m}$ & $\mathbf{3 0 0}$ & $\cos$ & rt \\
\hline
\end{tabular}




\section{APPENDLX A}

\section{TABLE B-4}

\section{ALL LIHEAP-ELIGIBLE, HIGH-EXPENDITURE HOUSEHOLDS REGIONAL / NORTHEAST}

\section{PERCENT OF EOUSEHOLDS}

\begin{tabular}{|c|c|c|c|c|c|c|c|c|c|c|c|c|c|c|c|}
\hline \multirow[b]{3}{*}{$\begin{array}{l}\text { Primingy } \\
\text { Heatings } \\
\text { Foet }\end{array}$} & \multicolumn{12}{|c|}{ Honsins Tye and Teane } & & & \\
\hline & \multicolumn{3}{|c|}{ Mobite Jlowe } & \multicolumn{3}{|c|}{ Singe Pemily } & \multicolumn{3}{|c|}{ Sours Multìnmity } & \multicolumn{3}{|c|}{ Lax Multtramily } & \multicolumn{2}{|c|}{ All Ilowing Tys } & \multirow[b]{2}{*}{$\begin{array}{l}\text { All } \\
\text { touns, } \\
\text { Flotds }\end{array}$} \\
\hline & Oma & Reot & $\begin{array}{l}\text { Bots } \\
\text { Tenurre }\end{array}$ & Onn & R=al & $\begin{array}{l}\text { Both } \\
\text { Tenutro }\end{array}$ & owo & Rent & $\begin{array}{l}\text { Both } \\
\text { Tenutes }\end{array}$ & Onvo & Rent & $\begin{array}{l}\text { Both } \\
\text { Tenurrs }\end{array}$ & Oma & 'Rent & \\
\hline Nolund Coss & 0.0 .8 & 13 & 18 & s6 & 24 & 1t.t & 8.2 & 13.1 & 192 & 0.0 & 98 & $9 B$ & 148 & 27.1 & 41.9 \\
\hline Eactricity & 000 & 0, & 0.0 & $\mathbf{0 . 0}$ & 1.6 & 1.6 & 0.0 & 6.7 & 6.7 & 0.0 & 52 & s2 & 0.0 & 135 & i3s \\
\hline J'uel Oill & 0.0 & t.o & 10 & 6.? & 2.4 & 11.1 & 1.1 & 9.0 & 100 & 0,0 & 10.7 & 10.7 & 9.8 & $\mathbf{2 . 1}$ & sea \\
\hline Kentenese & 5.3 & 23 & 7.8 & no & 0.0 & 0.0 & 00 & 00 & 0.0 & 0.0 & 0.0 & 0.0 & 33 & 25 & 78 \\
\hline Propane & 3.9 & 0.0 & 39 & 00 & 0.0 & 0.0 & 0.0 & 0.0 & 0.0 & 0.0 & 0.0 & 0.0 & 3.9 & 00 & 3.9 \\
\hline \multicolumn{16}{|l|}{ Ouber Pueks } \\
\hline \multicolumn{16}{|l|}{$\begin{array}{l}\text { No l leating } \\
\text { Puel Uped }\end{array}$} \\
\hline $\begin{array}{l}\text { All } \\
\text { jloweebolek }\end{array}$ & 92 & 53 & 145 & 17.4 & 64 & 28 & 72 & $28 \%$ & 36.0 & 0.0 & 25 & 256 & $\mathbf{3 1 8}$ & 807 & 1000 \\
\hline
\end{tabular}




\section{APPENDIX A}

\section{TABLE B-5}

\section{ALL LIHEAP-ELIGIBLE, HIGH-EXPENDITURE HOUSEHOLDS REGIONAL / MIDWEST}

\section{TttOUSANDS OF tLUSEHOLDS}

\begin{tabular}{|c|c|c|c|c|c|c|c|c|c|c|c|c|c|c|c|}
\hline \multirow[b]{3}{*}{$\begin{array}{l}\text { Primary } \\
\text { Heating } \\
\text { Foel }\end{array}$} & \multicolumn{12}{|c|}{ Howaing Type and Terore } & & & \multirow[b]{3}{*}{$\begin{array}{l}\text { All } \\
\text { tloumos } \\
\text { llotas }\end{array}$} \\
\hline & \multicolumn{3}{|c|}{ Mobite Itowe } & \multicolumn{3}{|c|}{ Single Panily } & \multicolumn{3}{|c|}{ Smats Multifamity } & \multicolumn{3}{|c|}{ Lage Multifintly } & \multicolumn{2}{|c|}{ All kourint $T_{\text {Ypes }}$} & \\
\hline & Omo & Reat & $\begin{array}{l}\text { Bott } \\
\text { Teatres }\end{array}$ & Oma & Repl & $\begin{array}{l}\text { Bouth } \\
\text { Tenumes }\end{array}$ & Own & Reol & $\begin{array}{l}\text { Bolb } \\
\text { Teaures }\end{array}$ & Onn & Rent & $\begin{array}{l}\text { Bolb } \\
\text { Teoores }\end{array}$ & Om & Rcal & \\
\hline Naturat Ges & 21 & 63 & 84 & 138 & 18 & 323 & s4 & 20 & 294 & 0 & 104 & 104 & 213 & 595 & Bas \\
\hline Dectridty & 52 & 0 & 52 & 60 & 0 & $\boldsymbol{\omega}$ & 0 & 39 & 19 & a & 28 & 20 & 112 & 47 & 160 \\
\hline Fuel oi & 0 & 0 & D & Bu & 40 & 124 & 0 & 24 & 24 & 0 & 0 & 0 & B & 6 & 148 \\
\hline Ketcesene & . & & & & & & & & & & & & & & \\
\hline Propanc & 100 & $\$ 9$ & 156 & 147 & $\boldsymbol{\mu A}$ & 170 & 0 & 17 & 13 & 0 & 0 & 0 & $\mathbf{Z}$ & 93 & 343 \\
\hline Other fruets & 31 & 0 & 31 & 0 & 0 & 0 & 0 & 0 & 0 & 0 & 0 & 0 & 31 & 0 & 31 \\
\hline $\begin{array}{l}\text { No 1leatins } \\
\text { Fuet Unod }\end{array}$ & & & & & & & . & & & & & & & & \\
\hline $\begin{array}{l}\text { All } \\
\text { Housefolvet }\end{array}$ & mn & 116 & 300 & 120 & 252 & $6+1$ & 54 & 299 & 353 & 0 & 133 & $\mathbf{1 3 0}$ & 69 & 800 & 1,490 \\
\hline
\end{tabular}




\section{APPENDIX A}

\section{TABLE B-6}

\section{ALL LIHEAP-ELIGIBLE, HGH-EXPENDITURE HOUSEHOLDS} REGIONAL / MIDWEST

\section{PERCENT OF HOUSEHOLDS}

\begin{tabular}{|c|c|c|c|c|c|c|c|c|c|c|c|c|c|c|c|}
\hline \multirow[b]{3}{*}{$\begin{array}{l}\text { Primary } \\
\text { Feating } \\
\text { Foes }\end{array}$} & \multicolumn{12}{|c|}{ Hoosins Type and Tenure } & & & \multirow[b]{3}{*}{$\begin{array}{l}\text { All } \\
\text { Ilouse } \\
\text { Ilotsts }\end{array}$} \\
\hline & \multicolumn{3}{|c|}{ Mobile tiooc } & \multicolumn{3}{|c|}{ Sinfje Pamily } & \multicolumn{3}{|c|}{ Samall Mult/smih } & \multicolumn{3}{|c|}{ Latge Multitamily } & \multicolumn{2}{|c|}{ All Flousting Typa } & \\
\hline & ONo & Reql & $\begin{array}{l}\text { Botb } \\
\text { Tendres }\end{array}$ & Omn & Reat & $\begin{array}{l}\text { Botb } \\
\text { Tenuers }\end{array}$ & Onn & Rea! & $\begin{array}{l}\text { Boch } \\
\text { Teawts }\end{array}$ & Ono & Rent & $\begin{array}{l}\text { Both } \\
\text { Tewores }\end{array}$ & Om & Repl & \\
\hline Netura Ge: & 14 & 43 & 56 & 9.3 & 126 & 21.9 & 36 & 16.1 & 19.7 & D & 7.0 & 7.0 & 113 & 399 & 513 \\
\hline Deetricity & 3.5 & 0.0 & 35 & 40 & 0.0 & 10 & 0.0 & 1.3 & 1.3 & 0.0 & 1.9 & 1.9 & 75 & 32 & to.7 \\
\hline Rocl oil & 0 & 0 & 0 & 5.6 & 27 & 83 & $\infty$ & 1.6 & 1.6 & 0.0 & 0.0 & 0.0 & $\$ .6$ & $\$ .9$ & 9.9 \\
\hline \multicolumn{16}{|l|}{ Kerosedoo } \\
\hline Pripane & 6.9 & 3.6 & 20.5 & 9.9 & 16 & 11.4 & 0,0 & t.1 & t.t & 0.0 & 0.0 & 0.0 & 16.8 & 6.3 & 23.0 \\
\hline Other Toeks & 21 & 0.0 & 21 & 0.0 & a.to & 0.0 & 0.0 & 0.0 & 0.0 & 0.0 & 00 & 0.0 & 2.9 & 0.0 & 2.] \\
\hline \multicolumn{16}{|l|}{$\begin{array}{l}\text { No Heatings } \\
\text { Puet Uned }\end{array}$} \\
\hline $\begin{array}{l}\text { All } \\
\text { Hoursirbolds }\end{array}$ & 129 & 78 & 21.7 & $2 \mathrm{a}$ & 169 & 15.7 & 36 & 200 & 27 & 00 & 89 & B.9 & 463 & $\mathbf{5 x}$ & 100.0 \\
\hline
\end{tabular}




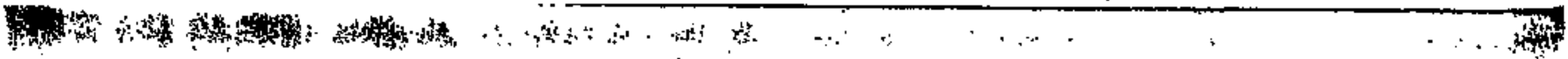

\section{APPENDIX A}

\section{TABLE B-7}

\section{ALL LIHEAP-ELIGIBLE, HIGH-EXPENDMURE HOUSEHOLDS} REGIONAL / SOUTH

\section{THOUSANDS OR HOUSEHOLDS}

\begin{tabular}{|c|c|c|c|c|c|c|c|c|c|c|c|c|c|c|c|}
\hline \multirow[b]{3}{*}{$\begin{array}{l}\text { Primary } \\
\text { Sienting } \\
\text { Foed }\end{array}$} & \multicolumn{12}{|c|}{ Hougieg Type and Tenure } & & & \multirow[b]{3}{*}{$\begin{array}{l}\text { All } \\
\text { Fliouse } \\
\text { Itodk }\end{array}$} \\
\hline & \multicolumn{3}{|c|}{ Mobilo Howe } & \multicolumn{3}{|c|}{ Sinfye Pamily } & \multicolumn{3}{|c|}{ Sinall Multthamily } & \multicolumn{3}{|c|}{ Latse Multifamity } & \multicolumn{2}{|c|}{ All flousing Types } & \\
\hline & $\operatorname{cms}$ & Rent & $\begin{array}{l}\text { Douth } \\
\text { Tequita }\end{array}$ & Omn & Rent & $\begin{array}{l}\text { Bouk } \\
\text { Teautes }\end{array}$ & ows & Renl & $\begin{array}{l}\text { Both } \\
\text { Tenurte }\end{array}$ & Own & Reat & $\begin{array}{l}\text { Both } \\
\text { Teourla }\end{array}$ & Oms & Real & \\
\hline Maleral Ges & 23 & 2 & 45 & 358 & $\mathbf{t s}$ & 516 & $\boldsymbol{n}$ & st & 76 & 0 & $\mathbf{2 0}$ & 20 & 400 & 253 & 656 \\
\hline Deatricity & 证 & 0 & 2 & 120 & 4 & 214 & 0 & 42 & 42 & 0 & 20 & 20 & 102 & 156 & 298 \\
\hline Puel on & $4 \mathbf{1}$ & 0 & 16 & 37 & 0 & 37 & 0 & 37 & 37 & 0 & 0 & 0 & 78 & 37 & 115 \\
\hline Ketroedes & 0 & t9 & 19 & $5 B$ & 91 & 349 & 0 & a & 0 & 0 & 0 & - & 58 & 109 & 367 \\
\hline Propane & 110 & $\boldsymbol{2 4}$ & 13 & 197 & 36 & 200 & 0 & 0 & 0 & o & 0 & o & 307 & 60 & 367 \\
\hline \multicolumn{16}{|l|}{ Other fluets } \\
\hline \multicolumn{16}{|l|}{$\begin{array}{l}\text { No theating } \\
\text { Fuel Uned }\end{array}$} \\
\hline All & 195 & 65 & 260 & $m$ & $m 3$ & 1,149 & $n$ & 150 & Ls & 0 & 39 & $\rightarrow$ & 968 & 6s & 1,601 \\
\hline
\end{tabular}

Source: 1990 Residential Erengy Consumption Survey 


\section{APPENDIX A}

\section{TABLE B-8}

\section{ALL LIHEAP-ELIGIBLE, HIGH-EXPENDTTURE HOUSEHOLDS REGIONAL / SOUTH}

\section{percent of HoUsenOLDS}

\begin{tabular}{|c|c|c|c|c|c|c|c|c|c|c|c|c|c|c|c|}
\hline \multirow[b]{3}{*}{$\begin{array}{l}\text { Prinury } \\
\text { fienting } \\
\text { Fted }\end{array}$} & \multicolumn{12}{|c|}{ Hotesibs Type and Teaure } & & & \multirow[b]{3}{*}{$\begin{array}{l}\text { All } \\
\text { Hous: } \\
\text { liolts }\end{array}$} \\
\hline & \multicolumn{3}{|c|}{ Notile Efome } & \multicolumn{3}{|c|}{ Siagke Pandly } & \multicolumn{3}{|c|}{ Smell Mulufamly } & \multicolumn{3}{|c|}{ Lerge Muttinmily } & \multicolumn{2}{|c|}{ All Ilousing Types } & \\
\hline & Own & Reot & $\begin{array}{l}\text { Botb } \\
\text { Teaures }\end{array}$ & Ond & Rersit & $\begin{array}{l}\text { Bodk } \\
\text { Tequrs }\end{array}$ & Oms & Reast & $\begin{array}{l}\text { Bath } \\
\text { Trepurs }\end{array}$ & Omin & Reat & $\begin{array}{l}\text { Both } \\
\text { Teavers }\end{array}$ & Own & $R \in 0 l$ & \\
\hline Natura Gas & $1 d$ & 14 & 29 & 23 & 98 & 322 & 14 & 3.4 & 47 & 0.0 & 12 & 12 & 22 & 158 & 40.9 \\
\hline Dextikity & 13 & 0.0 & 1.3 & 75 & 5.9 & 13.4 & $\mathbf{a . 0}$ & 28 & 26 & a. & 12 & 1.2 & 89 & 9.7 & 18.6 \\
\hline Puet Oid & 26 & o. & 26 & 23 & 0.0 & 23 & 0.0 & 23 & 23 & 0.0 & 0.0 & 0.0 & 4.9 & 23 & 72 \\
\hline Keftuseat & 0.0 & 12 & 12 & 36 & 5.6 & 93 & 0.0 & 0.0 & 0.0 & 00 & 0.0 & 0.0 & 3.6 & 6.9 & 10,4 \\
\hline Propase & 6.9 & 15 & B.4 & 123 & 22 & 145 & 0.0 & 0.0 & 0.0 & 00 & 0,0 & 0.0 & 19.1 & 38 & 229 \\
\hline \multicolumn{16}{|l|}{ Otber Puols } \\
\hline \multicolumn{16}{|l|}{$\begin{array}{l}\text { No Iteating } \\
\text { Puel Utined }\end{array}$} \\
\hline $\begin{array}{l}\text { All } \\
\text { Itrousechotds }\end{array}$ & 122 & 4.0 & 16.2 & 48 & 236 & $n .6$ & $1 A$ & as & 9.7 & 00 & 25 & 25 & 626 & 381 & 1000 \\
\hline
\end{tabular}




\section{APPENDIX A}

\section{TABLE B-9}

\section{ALL LIHEAP-ELIGIBLE, HIGH-EXPENDITURE HOUSEHOLDS REGIONAL / WEST}

\section{THOUSANDS OF ROUSEHOLDS}

\begin{tabular}{|c|c|c|c|c|c|c|c|c|c|c|c|c|c|c|c|}
\hline \multirow[b]{3}{*}{$\begin{array}{l}\text { Primey } \\
\text { Ileating } \\
\text { Foel }\end{array}$} & \multicolumn{12}{|c|}{ Howins Type and Teare } & & & \multirow[b]{3}{*}{$\begin{array}{l}\text { All } \\
\text { llowse } \\
\text { Jlowts }\end{array}$} \\
\hline & \multicolumn{3}{|c|}{ Mabit: Ifowe } & \multicolumn{3}{|c|}{ Single Pumily } & \multicolumn{3}{|c|}{ Sandl Moltifmily } & \multicolumn{3}{|c|}{ Lutt: Multifanlly } & \multicolumn{2}{|c|}{ Al Howsiag Types } & \\
\hline & Owo & Real & $\begin{array}{l}\text { Both } \\
\text { Tresutes }\end{array}$ & Omt & Reol & $\begin{array}{l}\text { Boeb } \\
\text { Teoures }\end{array}$ & Om & Rear & $\begin{array}{l}\text { Bolk } \\
\text { Tenurs: }\end{array}$ & Owa & Rest & $\begin{array}{l}\text { Botb } \\
\text { Teosis: }\end{array}$ & Ows & Rent & \\
\hline Natural Gas & 51 & 27 & 78 & s & $22 x$ & 317 & 0 & 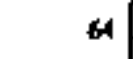 & 4 & o & is & 45 & 143 & 360 & 500 \\
\hline theatridity & 10 & 54 & 61 & 40 & $\mathbf{I 3 7}$ & 176 & 10 & 45 & 55 & 0 & $\$ 7$ & $s 7$ & 60 & 292 & $\$ 32$ \\
\hline \multicolumn{16}{|l|}{ Ifick od } \\
\hline \multicolumn{16}{|l|}{ Ketosese } \\
\hline Propme & 89 & 11 & $10 t$ & 19 & 0 & 19 & 0 & 0 & 0 & 0 & 0 & o & 109 & $\mathbf{3 1}$ & 200 \\
\hline \multicolumn{16}{|l|}{ Otbet Puets } \\
\hline \multicolumn{16}{|l|}{$\begin{array}{l}\text { No llesting } \\
\text { Fuel Uned }\end{array}$} \\
\hline $\begin{array}{l}\text { All } \\
\text { Ifousateritos }\end{array}$ & 151 & 92 & 262 & $\mathbf{s 1}$ & 361 & $\mathbf{s t z}$ & 10 & 109 & 219 & 0 & 101 & 10t & 312 & $\cos$ & 97s \\
\hline
\end{tabular}




\section{APPENDIX A}

\section{TABLE B-10}

\section{ALL LIHEAP-ELIGIBIE, HIGH-EXPENDITURE HOUSEHOLDS REGIONAL / WEST}

PORCENT OP HOUSEHOLDS

\begin{tabular}{|c|c|c|c|c|c|c|c|c|c|c|c|c|c|c|c|}
\hline \multirow[b]{3}{*}{$\begin{array}{l}\text { Primory } \\
\text { lleating } \\
\text { Foet }\end{array}$} & \multicolumn{12}{|c|}{ Honstins Type and Tenore } & & & \multirow[b]{3}{*}{$\begin{array}{l}\text { All } \\
\text { tlowese } \\
\text { likots: }\end{array}$} \\
\hline & \multicolumn{3}{|c|}{ Motile Hone } & \multicolumn{3}{|c|}{ Sinpte Pamily } & \multicolumn{3}{|c|}{ Sontis Multifomily } & \multicolumn{3}{|c|}{ Lere Mothifming } & \multicolumn{2}{|c|}{ All lhouring Nypes } & \\
\hline & Ono & ReDI & Both & Own & Peat & $\begin{array}{l}\text { Both } \\
\text { Teonar }\end{array}$ & Omn & Rent & $\begin{array}{l}\text { Both } \\
\text { Teprares }\end{array}$ & $0 \mathrm{~m}$ & Rear & $\begin{array}{l}\text { Both } \\
\text { Tenurs: }\end{array}$ & Doro & Real & \\
\hline Naluzat Oas & 5.2 & 2.8 & 8.0 & 95 & 23.0 & 325 & 0.0 & 65 & is & a:0 & 4.6 & 4.6 & 14.7 & 36.9 & 51.6 \\
\hline Deatikichy & 1.1 & 55 & 6.6 & 4.1 & 14.0 & 18.1 & 1.0 & 4.6 & 5.7 & 0.0 & 58 & 58 & 62 & 30,0 & 36.1 \\
\hline \multicolumn{16}{|l|}{ Puel OA } \\
\hline \multicolumn{16}{|l|}{ Ketotone } \\
\hline Propenter & 92 & $\mathbf{l + l}$ & j0.3 & 20 & 0.0 & 20 & 0.0 & 0.0 & 0.0 & 0.0 & 0,0 & 0.0 & 112 & 1.1 & 123 \\
\hline \multicolumn{16}{|l|}{ Other Puels } \\
\hline \multicolumn{16}{|l|}{$\begin{array}{l}\text { No lleating } \\
\text { Puet Uned }\end{array}$} \\
\hline All & '15. & 9.4 & 24.9 & ss & no & sis & 1.0 & 112 & 122 & D.0. & to.4 & 104 & 320 & 68.0 & 1000 \\
\hline
\end{tabular}




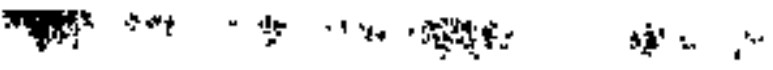

\section{APPENDIX A}

TABLE B-11

\section{ALL LIHEAP-ELIGIBLE, HIGH-EXPENDITURE HOUSEHOLDS NATIONAL}

\section{MEAN RESIDENTIAL ENERGY EXPENDITURES IN CURRENT DOUARS}

\begin{tabular}{|c|c|c|c|c|c|c|c|c|c|c|c|c|c|c|c|}
\hline \multirow[b]{3}{*}{$\begin{array}{l}\text { Priming } \\
\text { Heating } \\
\text { Pod }\end{array}$} & \multicolumn{12}{|c|}{ Housing Type and Tenare } & & & \multirow[b]{3}{*}{$\begin{array}{l}\text { All } \\
\text { Flousce } \\
\text { lipstse }\end{array}$} \\
\hline & \multicolumn{3}{|c|}{ Mabila Hoose } & \multicolumn{3}{|c|}{ Singe Panily } & \multicolumn{3}{|c|}{ Senell Multiramily } & \multicolumn{3}{|c|}{ Lerge Moltirinaily } & \multicolumn{2}{|c|}{ All Housedist Typ= } & \\
\hline & Om & Real & $\begin{array}{l}\text { Botb } \\
\text { Tenuires }\end{array}$ & Own & Real & $\begin{array}{l}\text { Both } \\
\text { Teourts }\end{array}$ & Owo & Real & $\begin{array}{l}\text { Both } \\
\text { Tequitrs }\end{array}$ & Own & Rerat & $\begin{array}{l}\text { Both } \\
\text { Tenures }\end{array}$ & Owp & Reat & \\
\hline Natorat Gis & $\pi 3$ & 978 & $8 \times 2$ & 1,18 & 1,266 & 1,208 & 1,84 & 1,142 & 1,295 & 0 & 72 & $m$ & 1,239 & 1,104 & 2,55 \\
\hline Electriclty & 1,172 & 555 & 931 & $12 n$ & 1,057 & 1,161 & 9 & 0,138 & 1,129 & 0 & 868 & 669 & 1,209 & 989 & 1,073 \\
\hline Poat Oit & $1, \pi-4$ & 2,041 & 1,765 & 1897 & 1,76 & 1,85s & 1,997 & 1,196 & 1,267 & 0 & 1,198 & 1,192 & $1,87 \pi$ & 1,323 & 1,567 \\
\hline Karosence & 1,6280 & 1,157 & 1,332 & 128 & 1,665 & 1,506 & 0 & 0 & 0 & 0 & 0 & 0 & 1,359 & 1,500 & 1,40 \\
\hline Propane & 1,335 & 1,49 & 1,359 & 1,357 & 1,166 & 1,314 & o & 1,670 & 1,670 & 0 & v & 0 & $1,3 * 6$ & 1,729 & 1,33 \\
\hline Orber Pucts & 1, तो & 0 & 1,297 & 0 & 0 & 0 & 0 & 0 & 0 & 0 & 0 & 0 & 1,27 & 0 & 12,237 \\
\hline \multicolumn{16}{|l|}{$\begin{array}{l}\text { No Iteating } \\
\text { Phel Uned }\end{array}$} \\
\hline $\begin{array}{l}\text { NI I } \\
\text { Ilowebolks }\end{array}$ & 1,250 & 1,000 & 1,196 & 1,341 & 1,266 & 1,311 & $1, \pi M$ & 1,162 & 1,260 & 0 & 856 & 856 & 1,346 & $1,1 \times 6$ & 1,220 \\
\hline
\end{tabular}




\section{APPENDIX A}

TABLE B-12

\section{ALL LIHEAP-ELIGIBLE, HIGH-EXPENDITURE HOUSEHOLDS NATIONAL}

\section{MEAN ANNUAL CASER RCOME}

\begin{tabular}{|c|c|c|c|c|c|c|c|c|c|c|c|c|c|c|c|}
\hline \multirow[b]{3}{*}{$\begin{array}{l}\text { Primary } \\
\text { llemtings } \\
\text { Feel }\end{array}$} & \multicolumn{12}{|c|}{ Foosing Type and Teane } & & & \multirow[b]{3}{*}{$\begin{array}{l}\text { All } \\
\text { Houst } \\
\text { I lolds }\end{array}$} \\
\hline & \multicolumn{3}{|c|}{ Hobile Illowos } & \multicolumn{3}{|c|}{ Single Pumity } & \multicolumn{3}{|c|}{ 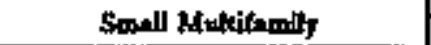 } & \multicolumn{3}{|c|}{ Lavge Multifeminy } & \multicolumn{2}{|c|}{ All flousist Types } & \\
\hline & Owa & Fent & $\begin{array}{l}\text { Both } \\
\text { Tentarca }\end{array}$ & ow & Reat & $\begin{array}{l}\text { Both } \\
\text { Tenures }\end{array}$ & Owe & Real & $\begin{array}{l}\text { Both } \\
\text { Tenutes }\end{array}$ & Own & Real & $\begin{array}{l}\text { Bolt } \\
\text { Tenors: }\end{array}$ & Ond & Rent & \\
\hline Nalutal ores & 5,794 & 8,527 & $+3,73$ & $8 \neq 0$ & 12,918 & 10,44 & 9,069 & A, 65 & $8, m$ & 0 & 6,621 & 6.625 & 8,114 & $\mathbf{3 0 , 0 3 1}$ & 9,301 \\
\hline Destricky & 10,989 & 6,50 & 9,300 & $7 m$ & 6,315 & 68815 & 4,500 & Q 667 & 8,430 & 0 & $9 \mathrm{~m}$ & $9,0 n$ & 2319 & 7,667 & 7869 \\
\hline Puel oil & B,750 & 9,500 & 8,47 & 13,091 & 11,79 & 12,76 & 5,500 & 10,382 & $10,0 \times s$ & 0 & 1,525 & 458 & 12,003 & 8,807 & 10,25 \\
\hline Kerocese & t0,204 & 6,45 & 2,486 & 12,141 & 11,104 & 11,510 & 0 & 0 & 0 & 0 & 0 & 0 & 11,268 & 9,642 & 10,30 \\
\hline Propane & $11, \pi 3$ & 6,120 & 10600 & 8,as8 & 9,515 & 8951 & D & 11,350 & 11,750 & 0 & 0 & a & 10,364 & 7,913 & 9:117 \\
\hline Olber ther & 5,500 & 0 & 5,500 & 0 & 0 & 0 & 0 & 0 & 0 & 0 & 0 & G & 5,500 & 0 & 5,500 \\
\hline \multicolumn{16}{|l|}{$\begin{array}{l}\text { No Hextins: } \\
\text { Puse Uled }\end{array}$} \\
\hline $\begin{array}{l}\text { All } \\
\text { Jlowsebolds }\end{array}$ & 10,139 & $7 m$ & 9,195 & 9000 & 10,959 & 9,809 & 8542 & 9,052 & 897 & 0 & 6,553 & 6,953 & 9,324 & 9,195 & 9,251 \\
\hline
\end{tabular}




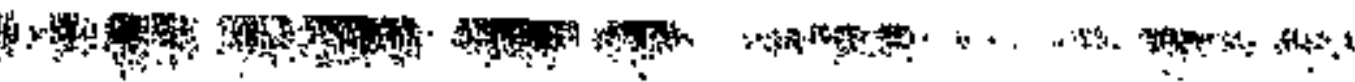

\section{APPENDIX A}

TABLE B-13

\section{ALd LIHEAP.ELIGIBLE, HIGH-EXPENDITURE HOUSEHOLDS NATIONAL}

MEAN ENERGY BURDEN - EXYENDITURES AS D OF INCOME

\begin{tabular}{|c|c|c|c|c|c|c|c|c|c|c|c|c|c|c|c|}
\hline \multirow[b]{3}{*}{$\begin{array}{l}\text { Prituing } \\
\text { Mestions } \\
\text { Fuck }\end{array}$} & \multicolumn{12}{|c|}{ Honsing Type and Tenure } & & & \multirow[b]{3}{*}{$\begin{array}{l}\text { All } \\
\text { floume } \\
\text { Illowde }\end{array}$} \\
\hline & \multicolumn{3}{|c|}{ Mahile Home } & \multicolumn{3}{|c|}{ Singke Patulty } & \multicolumn{3}{|c|}{ Smill Moltifimity } & \multicolumn{3}{|c|}{ Lefo Maltifanify } & \multicolumn{2}{|c|}{ All Housing 'Гypes } & \\
\hline & ONo & Reat & $\begin{array}{l}\text { noth } \\
\text { Teaurs }\end{array}$ & Ont & Rent & $\begin{array}{l}\text { Both } \\
\text { Tenorr }\end{array}$ & Omo & Real & $\begin{array}{l}\text { Booth } \\
\text { Tremu res }\end{array}$ & Own & Rent & $\begin{array}{l}\text { Both } \\
\text { Tenums: }\end{array}$ & Own & Rent & \\
\hline Noltiral Ges: & B.4 & 165 & 160 & 184 & 14 & 16.7 & 250 & 172 & 18,9 & 0 & 34.4 & 14.4 & t9.1 & s.7 & 17.0 \\
\hline Electricity & 10.5 & 83 & 9.7 & 213 & 29.7 & 25.7 & 20 & 26.1 & 25.8 & 0.0 & 10.9 & 10.9 & 28.4 & 22 & 21.0 \\
\hline Fued or & 20.7 & $2 ! 5$ & 208 & 176 & 148 & 169 & 363 & 25,2 & 259 & 0.0 & 609 & 60.8 & IE.S & 342 & 273 \\
\hline Kerosede & 37.7 & 314 & $35.7^{*}$ & 10.1 & 20 & 17.9 & 00 & 0.0 & 0.0 & 0.0 & 0.0 & 0.0 & 227 & 203 & 216 \\
\hline Progense & t2s & 26.9 & 15.7 & $1: 2$ & 13.0 & $17 s$ & 0.0 & 142 & $1 \leqslant 2$ & 0.0 & 0.0 & 0.0 & 15.6 & 20.6 & 165 \\
\hline Other Itsels & 225 & 0.0 & t2s & 0.0 & n.o & 0.0 & 0.0 & 0.0 & 0.0 & 00 & 0.0 & 0.0 & 225 & 0.0 & 225 \\
\hline \multicolumn{16}{|l|}{$\begin{array}{l}\text { No Heating } \\
\text { Puet Uned }\end{array}$} \\
\hline $\begin{array}{l}\text { All } \\
\text { llowreboldk }\end{array}$ & 15.7 & 20.3 & ב3 & 18.4 & 18.9 & tes. & 25 & 20.4 & 212 & 0.0 & 23 & 203 & 18.1 & 202 & 192 \\
\hline
\end{tabular}

Soureci 1990 Restdential Entrzy Cansupppion Survey 
APPENDIX A

TABLE B-14

\section{ALL LIHEAP-ELIGIBLE, HIGH-EXPENDITURE HOUSEHOLDS BY PROGRAM PARTICIPATION NATIONAL}

THIOUSANDS OF HOUSEHOL.DS

\begin{tabular}{|c|c|c|c|c|c|c|c|c|c|c|c|c|c|c|c|}
\hline & \multicolumn{12}{|c|}{ Housing Type and Teare } & & & \multirow[b]{3}{*}{$\begin{array}{l}\text { All } \\
\text { Hownes } \\
\text { Iloteds }\end{array}$} \\
\hline & \multicolumn{3}{|c|}{ Motiste llowe } & \multicolumn{3}{|c|}{ Single Promily } & \multicolumn{3}{|c|}{ Sonell Mortifrenily } & \multicolumn{3}{|c|}{ Letg Mwtifamily } & \multicolumn{2}{|c|}{ An flowsing Typa } & \\
\hline & Owo & Rent & $\begin{array}{l}\text { Both } \\
\text { Tenures }\end{array}$ & ONo & Peat & $\begin{array}{l}\text { Botb } \\
\text { Teaures }\end{array}$ & Omo & Reat & $\begin{array}{l}\text { Botb } \\
\text { Temures }\end{array}$ & Owo & Pteat & $\begin{array}{l}\text { Both } \\
\text { Tesures }\end{array}$ & ond & R*al & \\
\hline 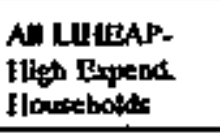 & $6 n$ & 321 & 988 & 1,510 & 1,049 & 2,559 & $\mathbf{v 2}$ & 804 & 956 & 0 & $\mathbf{s o r}$ & 507 & 2,299 & 2,681 & 4,900 \\
\hline $\begin{array}{l}\text { AFDC } \\
\text { Recipiunte }\end{array}$ & \$ & 90 & 399 & 69 & $m$ & 295 & 0 & 187 & 183 & o & 59 & $s$ & 161 & 558 & 719 \\
\hline sSt Recipients & 46 & 6 & 115 & 236 & 51 & 287 & 11 & 48 & m & - & $\mathbf{9 8}$ & 9 & 209 & $2 \times 6$ & sst \\
\hline $\begin{array}{l}\text { leating } \\
\text { Astituact } \\
\text { Recipiteats }\end{array}$ & 123 & lon & 20 & 1,33 & $\begin{array}{r}245 \\
\end{array}$ & $3 \pi d$ & 29 & 131 & 16] & 0 & 19 & 19 & 2880 & 500 & ros \\
\hline $\begin{array}{l}\text { Pood Stamps } \\
\text { Roctititits }\end{array}$ & \pm 6 & 141 & $\mathbf{s e s}$. & 266 & 300 & S\% & 11 & 225 & 206 & 0 & 193 & 193 & 441 & 690 & 1,331 \\
\hline 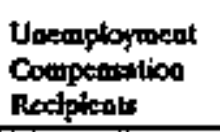 & 36 & 0 & 35 & 53 & 49 & 10 & 29 & 4 & 7 & 0 & $n$ & $n$ & $t 18$ & 15 & 233 \\
\hline $\begin{array}{l}\text { Sotbidirad } \\
\text { Ilouring } \\
\text { Rosipieats }\end{array}$ & 0 & 47 & 7 & 0 & $\boldsymbol{A}$ & $\boldsymbol{A}$ & 0 & 131 & 111 & 0 & 36 & $\mathbf{3 6}$ & 0 & 287 & 27 \\
\hline
\end{tabular}




\section{APPENDIX A}

\section{TABLE B-15}

\section{ALL LIHEAP-ELIGIBLE, HIGH-EXPENDITURE HOUSEHOLDS BY PROGRAM PARTICIPATTON NATIONAL}

\section{PERCENT OF HOUSEHOLDS}

\begin{tabular}{|c|c|c|c|c|c|c|c|c|c|c|c|c|c|c|c|}
\hline & \multicolumn{12}{|c|}{ Hoosins Type and Tenure } & & & \multirow[b]{3}{*}{$\begin{array}{l}\text { AN } \\
\text { Ilousere } \\
\text { Itolds }\end{array}$} \\
\hline & \multicolumn{3}{|c|}{ Matita Howe } & \multicolumn{3}{|c|}{ Slnge Pamily } & \multicolumn{3}{|c|}{ Smell Modtitamity } & \multicolumn{3}{|c|}{ Lnge Multitumily } & \multicolumn{2}{|c|}{ All Houning Thes } & \\
\hline & ONo & Reat & $\begin{array}{l}\text { Botb } \\
\text { Tcaurs }\end{array}$ & Ong & Rent & $\begin{array}{l}\text { Dooth } \\
\text { Teauja }\end{array}$ & $O_{m n}$ & Ferat & $\begin{array}{l}\text { Bollh } \\
\text { Tenute }\end{array}$ & Own & Renl & $\begin{array}{l}\text { Boch } \\
\text { Tentras }\end{array}$ & Own & Rent & \\
\hline $\begin{array}{l}\text { N UFEAP- } \\
\text { Figh Enpeod } \\
\text { Ilomelolds }\end{array}$ & 4 & R.3 & 163 & 16.3 & $\boldsymbol{\Sigma} .0$ & $\$ 1.7$ & 83 & 16.7 & 25.0 & 0,0 & 16.7 & 16.7 & 33 & 66.7 & 100.0 \\
\hline $\begin{array}{l}\text { ArDC } \\
\text { Recipients }\end{array}$ & 125 & 125 & $\mathbf{z x o}$ & 125 & $\mathbf{5 . 0}$ & ns & 0.0 & $\mathbf{2 5 , 0}$ & $\mathbf{2 5 . 0}$ & 0.0 & 125 & 125 & 80 & so & 100.0 \\
\hline sST Roctpicots & 125 & tas & 25.0 & 125 & 125 & $\mathbf{2 5 . 0}$ & 125 & 125 & $\mathbf{8 . 0}$ & a.d & 50 & $\mathbf{8 5 . 0}$ & 375 & 625 & 100.0 \\
\hline $\begin{array}{l}\text { Jlonting } \\
\text { Aesidenes } \\
\text { Reciplents }\end{array}$ & 10,0 & 10,0 & 20.0 & 10.0 & 30.0 & $\$ 0.0$ & 10.0 & 200 & 30,0 & $\mathbf{0 , 0}$ & 10.0 & 10,0 & $\mathbf{3 0 . 0}$ & 70.0 & 100.0 \\
\hline $\begin{array}{l}\text { Food Stanpx } \\
\text { Redplents }\end{array}$ & 9.1 & 9.1 & 182 & 9.1 & $n 3$ & $36 t$ & 9.t & J日22 & 273 & 0.0 & IB2 & 18.2 & $n 3$ & 2.7 & 100.0 \\
\hline $\begin{array}{l}\text { Unemplomineat } \\
\text { Compensation } \\
\text { Recipiteols }\end{array}$ & 16.7 & $\mathbf{0 . 0}$ & 56.7 & 16.7 & $1 \leqslant j$ & 3 & 16.7 & 16.7 & 333 & 0.0 & 167 & 167 & 50.0 & 50.0 & 3000 \\
\hline 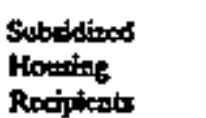 & 0,0 & 143 & 143 & 0.0 & 429 & 129 & 0,0 & 286 & 286 & 0.0 & t1.3 & 143 & 0.0 & 1000 & $t 00,0$ \\
\hline
\end{tabular}

Sourc: 1990 Resdential Entray Consumplian Survey 


\section{APPENDLX A}

\section{TABLE B-16}

\section{ALL LIHIAP-ELIGIBLE, HIGH-EXPENDITURE HOUSEHOLDS BY PROGRAM PARTICIPATYON NATIONAL}

\section{MRAN RESIDENTINL ENERGY EXPENDITURES IN CURRENT DOUARS}

\begin{tabular}{|c|c|c|c|c|c|c|c|c|c|c|c|c|c|c|c|}
\hline & \multicolumn{12}{|c|}{ Honston Type and Tearie } & & & \multirow[b]{3}{*}{$\begin{array}{l}\text { All } \\
\text { Itouse } \\
\text { Ilotds }\end{array}$} \\
\hline & \multicolumn{3}{|c|}{ Motive Hame } & \multicolumn{3}{|c|}{ Single Pumily } & \multicolumn{3}{|c|}{ Sorail Multifumity } & \multicolumn{3}{|c|}{ Lage Multíamily } & \multicolumn{2}{|c|}{ All loustins Types } & \\
\hline & Owt & Reat & $\begin{array}{l}\text { Bouk } \\
\text { Teautes }\end{array}$ & Owo & Rent & $\begin{array}{l}\text { Bolb } \\
\text { Tcoure: }\end{array}$ & Ong & Rept & $\begin{array}{l}\text { Botb } \\
\text { Teaures }\end{array}$ & ONd & Rent & $\begin{array}{l}\text { Both } \\
\text { Tcourse }\end{array}$ & Own & Real & \\
\hline $\begin{array}{l}\text { Alt LHPAP- } \\
\text { lliph Expeod } \\
\text { 1)ousebolde }\end{array}$ & 1,280 & 1,090 & 1,196 & 1,31 & $1,2 \times 6$ & 1,311 & $1,7 n$ & 1,162 & 1,253 & 0 & 856 & 656 & 1,346 & 1,136 & 1,20 \\
\hline $\begin{array}{l}\text { NMDC } \\
\text { Resipteder }\end{array}$ & 1,101 & $1,2,25$ & 1,165 & 1,407 & 1,415 & $1,4 t 5$ & 0 & 1,218 & 3,258 & 0 & $6 \%$ & 696 & 1,200 & 1,244 & 1,25 \\
\hline SS1 Rocipteats & 1, (A:ar & 1,000 & $1, \infty \times$ & 1,061 & 999 & $1,0 \times 0$ & $5 s 3$ & 877 & 784 & o & 981 & 9a1 & 1,045 & $m$ & t:00 \\
\hline 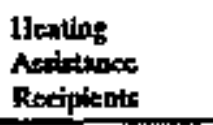 & 1,256 & 974 & 1,127 & 1,153 & $1,26 \mathrm{GH}$ & 1,530 & 2,457 & 1,113 & 1,355 & 0 & 9in & 907 & 1,469 & 1,50 & 1,266 \\
\hline $\begin{array}{l}\text { Aood Stantes } \\
\text { Reupiptents }\end{array}$ & 1,316 & 1,303 & 1,310 & 1,304 & 1295 & 1,299 & 5.53 & 1200 & 1,169 & 0 & 865 & 865 & 1,289 & 1,17 & 1,216 \\
\hline 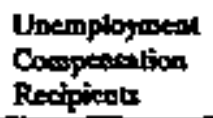 & 1,424 & $\mathbf{0}$ & 1,024 & $1,3 \mathrm{~m}$ & 1,429 & 1,363 & 2,437 & 1,151 & 1,606 & 0 & 1,149 & $t, 149$ & 1,621 & 1,270 & 1,448 \\
\hline $\begin{array}{l}\text { Subsidbed } \\
\text { Hourint } \\
\text { Recipitents }\end{array}$ & 0 & 1,160 & 1,168 & 0 & 922 & 90 & a & 1,1t0 & $\mathbf{t}, 110$ & 0 & 985 & 935 & 0 & 1,050 & 1,050 \\
\hline
\end{tabular}




\section{APPENDIX A}

\section{TABLE B-17}

\section{ALL LIHEAP-ELIGIBLE, HIGH-EXPENDITURE HOUSEHOLDS BY PROGRAM PARTICIPATION NATIONAL}

MEAN ENBRGX BURDEN - BXPENDITURES AS $\%$ OF INCOMT

\begin{tabular}{|c|c|c|c|c|c|c|c|c|c|c|c|c|c|c|c|}
\hline & \multicolumn{12}{|c|}{ Honsles Type and Teanere } & & & \multirow[b]{3}{*}{$\begin{array}{l}\text { All } \\
\text { Houre } \\
\text { Jlonts }\end{array}$} \\
\hline & \multicolumn{3}{|c|}{ Mobide llowe } & \multicolumn{3}{|c|}{ Single Ponily } & \multicolumn{3}{|c|}{ Sand Mulbifamily } & \multicolumn{3}{|c|}{ 1.1. Mulunamly } & \multicolumn{2}{|c|}{ All tlowing Typer } & \\
\hline & 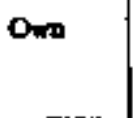 & Rent & $\begin{array}{l}\text { Bolh } \\
\text { Tedures }\end{array}$ & Om & Renl & $\begin{array}{l}\text { Bouk } \\
\text { Tanutas }\end{array}$ & Own & Real & $\begin{array}{l}\text { Both } \\
\text { Teauras }\end{array}$ & Omn & Renl & $\begin{array}{l}\text { Both } \\
\text { Teoores }\end{array}$ & Own & Ptent & \\
\hline 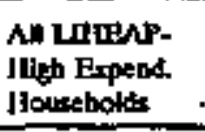 & 16 & 20 & $n$ & 18 & 19 & 19 & 25 & 20 & 21 & - & 22 & 22 & 18 & 20 & 19 \\
\hline $\begin{array}{l}A \mathrm{ADC} \\
\text { Poxipicats }\end{array}$ & 31 & 18 & $\mathbf{z}$ & 16 & 25 & $\mathbf{2 3}$ & 0 & 3 & 39 & 0 & 11 & IJ & $\boldsymbol{t}$ & 27 & $n$ \\
\hline SSI Recipleols & $\mathbf{u s}$ & 96 & 17 & 19 & 17 & 18 & 37 & 18 & 22 & 0 & 26 & $\mathbf{2 x}$ & 19 & x & 19 \\
\hline $\begin{array}{l}\text { Heating } \\
\text { Axtistiox } \\
\text { Recipteat }\end{array}$ & 27 & $\mathbf{n}$ & 25 & $m$ & 2 & 21 & $\mathbf{x}$ & 21 & 22 & 0 & 60 & 60 & 28 & $\mathbf{n}$ & s \\
\hline 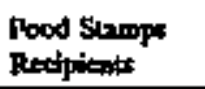 & $\boldsymbol{z} \boldsymbol{x}$ & $\mathbf{2 1}$ & $\mathbf{n}$ & $\mathbf{2 0}$ & $\mathbf{x}$ & $n$ & 37 & 35 & 36 & 0 & 30 & 30 & 21 & $n$ & 25 \\
\hline $\begin{array}{l}\text { Unemplopitest } \\
\text { Dedpentioe } \\
\text { Reciptents }\end{array}$ & 11 & 0 & 11 & 8 & B & 8 & 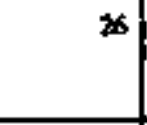 & 10 & 16 & 0 & 49 & 49 & 13 & 17 & $\boldsymbol{w}$ \\
\hline $\begin{array}{l}\text { Subididiaxd } \\
\text { Jlooting } \\
\text { Reciplentr }\end{array}$ & 0 & 21 & 21 & 0 & t9 & 19 & 0 & 18 & 10 & 0 & 9 & $B$ & 0 & $\mathbf{1 7}$ & 17 \\
\hline
\end{tabular}




\section{APPENDIX A}

TABLE B-18

\section{ALL LIHEAP-ELIGIBLE, HIGH-EXPENDITURE HOUSEHOLDS BY DEMOGRAPHIC CHARACTERISTICS NATIONAL}

\section{THOUSANDS OF HOUSEHOLDS}

\begin{tabular}{|c|c|c|c|c|c|c|c|c|c|c|c|c|c|c|c|}
\hline & \multicolumn{12}{|c|}{ Housing Type and Tewure } & & & \multirow[b]{3}{*}{$\begin{array}{l}\text { All } \\
\text { Ifoence } \\
\text { I lolds }\end{array}$} \\
\hline & \multicolumn{3}{|c|}{ Moble Home } & \multicolumn{3}{|c|}{ Stanpso Promity } & \multicolumn{3}{|c|}{ Soall Molifinmily } & \multicolumn{3}{|c|}{ Leto Nultramily } & \multicolumn{2}{|c|}{ All Iloutine Types } & \\
\hline & Owd & Reat & $\begin{array}{l}\text { Beth } \\
\text { Tearfes }\end{array}$ & Ons & Pent & $\begin{array}{l}\text { Botb } \\
\text { Teastres }\end{array}$ & and & Psat & $\begin{array}{l}\text { Boch } \\
\text { Teatures }\end{array}$ & ONo & Real & $\begin{array}{l}\text { Both } \\
\text { Tenules }\end{array}$ & Owo & Real & \\
\hline 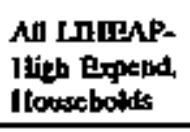 & का? & zzt & 98 & 1,510 & t,ong & 2,559 & 152 & 804 & 956 & 0 & $\operatorname{son}$ & solt & 209 & 2,681 & 4,980 \\
\hline $\begin{array}{l}\text { Ilowsebolds } \\
\text { With Elderty } \\
\text { Metmbets }\end{array}$ & 287 & 10 & $m$ & 1,177 & 211 & 1,419 & 67 & 15 & 221 & 0 & 248 & $2 A 8$ & 1,531 & 6et & 2,216 \\
\hline $\begin{array}{l}\text { llouscebolts } \\
\text { with Children }\end{array}$ & 354 & an & 561 & 354 & 681 & 1,023 & 17 & 399 & 366 & 0 & 116 & 116 & $m s$ & 1,353 & 2,078 \\
\hline 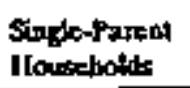 & 124 & 87 & 211 & 139 & 375 & sor & t) & 200 & 205 & 0 & B8 & 85 & 24 & $75 s$ & 1,009 \\
\hline $\begin{array}{l}\text { Africant } \\
\text { American } \\
\text { Ilousebolts }\end{array}$ & 86 & 60 & 146 & $\mathbf{3 6}$ & 301 & 745 & $6 B$ & 29 & 306 & 0 & 162 & 163 & 517 & $\mathbf{3 4 2}$ & 1,359 \\
\hline $\begin{array}{l}\text { Hilepenie } \\
\text { Itouserbolds }\end{array}$ & to & $\vec{x}$ & 38 & 161 & 185 & 347 & 0 & 75 & 75 & 0 & $\$$ & 38 & 171 & 300 & 497 \\
\hline $\begin{array}{l}\text { White } \\
\text { Howsebolds }\end{array}$ & $\$ s 1$ & 201 & 812 & 4,110 & 627 & 1,788 & ES & 50 & 615 & 0 & 345 & 36 & 1,746 & 1,746 & 3510 \\
\hline
\end{tabular}


-

\section{APPENDDX A}

\section{TABLE B-19}

\section{ALL LHEAP-ELIGIBLE, HIGH-EXPENDITURE HOUSEHOLDS BY DEMOGRAPHIC CHARACTERISTICS NATIONAL}

\section{PERCENT OF HOUSEHOLDS}

\begin{tabular}{|c|c|c|c|c|c|c|c|c|c|c|c|c|c|c|c|}
\hline & \multicolumn{12}{|c|}{ Hoaging Type and Temere } & & & \multirow[b]{3}{*}{$\begin{array}{l}\text { Alt } \\
\text { Hoose } \\
\text { jlowts }\end{array}$} \\
\hline & \multicolumn{3}{|c|}{ Mobile floone } & \multicolumn{3}{|c|}{ Single Padilly } & \multicolumn{3}{|c|}{ Sandl Multithmily } & \multicolumn{3}{|c|}{ Lergo Mullitamily } & \multicolumn{2}{|c|}{ Ab Hoursing Types } & \\
\hline & Ond & Renl & $\begin{array}{l}\text { Botb } \\
\text { Teaures }\end{array}$ & Own & Pteot & $\begin{array}{l}\text { Doth } \\
\text { Tenures }\end{array}$ & om & Redi & $\begin{array}{l}\text { Dotb } \\
\text { Teaures: }\end{array}$ & ONo & Real & $\begin{array}{l}\text { Boch } \\
\text { Teaures }\end{array}$ & Owa & Reat & \\
\hline 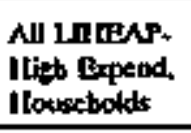 & 83 & 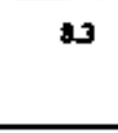 & 167 & 167 & 250 & 41.3 & R.3 & 167 & S.o & 0.0 & 163 & 167 & $\mathbf{I 3}$ & 667 & 100,0 \\
\hline $\begin{array}{l}\text { Ilowescbolds } \\
\text { with Didenty } \\
\text { Mewobers }\end{array}$ & 9.1 & 9.1 & ta.z & 182 & 273 & 455 & 9.1 & 102 & 0.0 & 0.0 & 182 & 1B2 & +36.4 & 636 & 100.0 \\
\hline $\begin{array}{l}\text { Ilocsebolds } \\
\text { with Children }\end{array}$ & 10.0 & 10.0 & 20.0 & to.to & 30.0 & wat & 10.0 & 200 & 30.0 & 0.0 & 10,0 & 100 & 30.0 & no & 100.0 \\
\hline $\begin{array}{l}\text { Single-Pwarat } \\
\text { llowsebollss }\end{array}$ & 125 & 125 & 25.0 & t2s & $37 s$ & 50.0 & 0.0 & 12.5 & 125 & 0,0 & 123 & 125 & 20 & 7.0 & 1000 \\
\hline $\begin{array}{l}\text { Altiato- } \\
\text { American } \\
\text { floxisebolks }\end{array}$ & 10.0 & 10.0 & 200 & 10,0 & 20.0 & 300 & 10,0 & 20.0 & 30.0 & 0.0 & $\mathbf{m i n}$ & 200 & 30.0 & 70.0 & 1000 \\
\hline 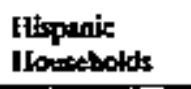 & S21 & 12.5 & 25,0 & 25.0 & 26.0 & S0.0 & 0.0 & 123 & t2s & 0.0 & 123 & 125 & 375 & 625 & 100,0 \\
\hline $\begin{array}{l}\text { While } \\
\text { Ilowelds }\end{array}$ & 9.5 & 9.1 & 18.2 & 182 & $n 3$ & us & 9.1 & 182 & 275 & 0.0 & 9.1 & 9.1 & 36.4 & 636 & 100,0 \\
\hline
\end{tabular}




\section{APPENDEX A}

TABLE B-20

ALL LIHEAP-ELIGIBLE, HIGH-EXPENDITURE HOUSEHOLDS BY DEMOGRAPHIC CHARACTERISTICS NATIONAL

\section{MEAN RESIDENTUAL ENERGY EXPENDTTURSS IN CURRENT DOLARS}

\begin{tabular}{|c|c|c|c|c|c|c|c|c|c|c|c|c|c|c|c|}
\hline & \multicolumn{12}{|c|}{ Howalns Type and Temary } & & & \multirow[b]{3}{*}{$\begin{array}{l}\text { All } \\
\text { Howose } \\
\text { Ilodks }\end{array}$} \\
\hline & \multicolumn{3}{|c|}{ Nobits Hoose } & \multicolumn{3}{|c|}{ Singk Pamily } & \multicolumn{3}{|c|}{ Small Muhifamily } & \multicolumn{3}{|c|}{ Lerec Mullifmily } & \multicolumn{2}{|c|}{ Nil tloustos Typs } & \\
\hline & Omit & Peal & $\begin{array}{l}\text { Botb } \\
\text { Tenutes }\end{array}$ & Den & Real & $\begin{array}{l}\text { Doeb } \\
\text { Teaurs: }\end{array}$ & ONo & Reat & $\begin{array}{l}\text { Bolb } \\
\text { Tenares }\end{array}$ & Onv & Reat & $\begin{array}{l}\text { Botb } \\
\text { Teroses: }\end{array}$ & Own & Real & \\
\hline 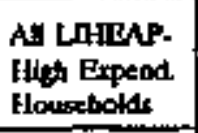 & 1,250 & 1,090 & $1,1 \% 6$ & 1,341 & 1,20 & 1,511 & 1.97 & 1,162 & 1,263 & 0 & 856 & $8 s$ & $t, 346$ & 1,136 & 1,235 \\
\hline $\begin{array}{l}\text { Housebolds } \\
\text { with Elderty } \\
\text { Mconbegt }\end{array}$ & 1,034 & $\$ 57$ & 96 & 1,290 & 1,042 & 1,268 & 1506 & B66 & 1,059 & 0 & $\mathbf{8 8 1}$ & 881 & $t_{1}, 252$ & 910 & 1,146 \\
\hline $\begin{array}{l}\text { Housetbols } \\
\text { with Childreo }\end{array}$ & 1569 & 1,705 & $1, \mu s$ & 1,566 & 1,362 & 1,429 & 2,121 & 1,348 & 1,383 & 0 & $1,02 x$ & 1,06 & $1,5 n$ & 1,310 & 1,400 \\
\hline $\begin{array}{l}\text { Singe-Patiot } \\
\text { llowerelsts }\end{array}$ & 1,37 & 900 & 1,181 & 1,466 & 1,313 & 1,352 & 0 & 1,29 & 1,259 & 0 & 1,000 & 1,000 & 1,422 & 1,210 & 1,263 \\
\hline 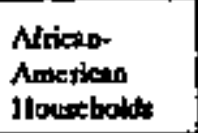 & $t, 473$ & $t, 127$ & 1,200 & 1509 & 1,42 & $1 ; 382$ & 2046 & 1,09 & 1,187 & 0 & 8035 & 935 & 1,04 & 1,262 & 1,335 \\
\hline $\begin{array}{l}\text { Hilipanic } \\
\text { Hipueholds }\end{array}$ & 1,212 & 53 & 708 & 2,145 & 1,126 & $t, 140$ & 0 & 1,599 & 1,598 & 0 & 1,592 & 1,532 & 1,149 & 1,244 & $t, 211$ \\
\hline $\begin{array}{l}\text { While } \\
\text { Howsectolts }\end{array}$ & 1,216 & 1,061 & 1,172 & בצד, & 1,1200 & 1,100 & 1,59 & 1,098 & 1,167 & 0 & sos & 865 & 1,51 & $i, 0<8$ & 1,189 \\
\hline
\end{tabular}




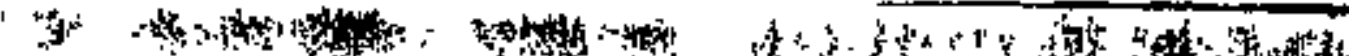

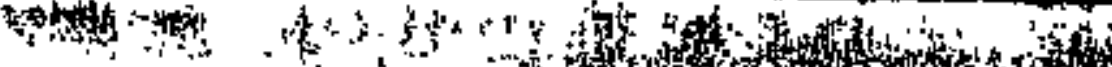

\section{APPENDIX A}

\section{TABLE B-21}

\section{ALL LIHEAP-ELIGIBLE, HUGH-EXPENDITURE HOUSEHOLDS BY DEMOGRAPHC CHARACTERISTICS} NATIONAL

\section{WDAN ENERGY BURDEN - EXPENDITURES AS \% OF RCOME}

\begin{tabular}{|c|c|c|c|c|c|c|c|c|c|c|c|c|c|c|c|}
\hline & \multicolumn{12}{|c|}{ Housfing Type and Tenore } & & & \multirow[b]{3}{*}{$\begin{array}{l}\text { All } \\
\text { ltows: } \\
\text { tlowids }\end{array}$} \\
\hline & \multicolumn{3}{|c|}{ Mobile lifme } & \multicolumn{3}{|c|}{ Sarpe Pumbing } & \multicolumn{3}{|c|}{ Somall Mutaliamtig } & \multicolumn{3}{|c|}{ Er|r Mútifamily } & \multicolumn{2}{|c|}{ At llowtist Types } & \\
\hline & Owo & Redl & $\begin{array}{l}\text { Both } \\
\text { Teaurs }\end{array}$ & Ona & Reat & $\begin{array}{l}\text { Boub } \\
\text { Tequres }\end{array}$ & Ono & Reat & $\begin{array}{l}\text { Bath } \\
\text { Tequres }\end{array}$ & Ows & Rta: & $\begin{array}{l}\text { Boeb } \\
\text { Tenures }\end{array}$ & Owa & Reen & \\
\hline 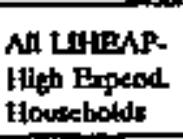 & 16 & $\mathbf{2 0}$ & 17 & 19 & tg & 19 & $\mathbf{z}$ & 20 & $\mathbf{2 1}$ & 0 & 2 & $\mathbf{n}$ & 18 & $\mathbf{2 0}$ & tg \\
\hline 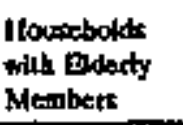 & 13 & 9 & $\mathbf{t 2}$ & 19 & Ls & 19 & 31 & 13 & 18 & o & 18 & 18 & 18 & is & v \\
\hline $\begin{array}{l}\text { tiousholds } \\
\text { with owldrea }\end{array}$ & 18 & 21 & t9 & 14 & 17 & 16 & 11 & 25 & 25 & 0 & 41 & 41 & 16 & 22 & $\mathbf{2 0}$ \\
\hline $\begin{array}{l}\text { Sinte-Pureal } \\
\text { Housebolds }\end{array}$ & $\mathbf{n a}$ & $\mathbf{z s}$ & 24 & 17 & is & 21 & 0 & 31 & 31 & 0 & 39 & 39 & 20 & 27 & 25 \\
\hline $\begin{array}{l}\text { Arrian- } \\
\text { Ameriken } \\
\text { Houstosits }\end{array}$ & 14 & 36 & $\ddot{x}$ & 18 & 21 & 19 & $\boldsymbol{H}$ & ty & $\mathbf{2 z}$ & 0 & 19 & 19 & 19 & 21 & $\mathbf{2 0}$ \\
\hline $\begin{array}{l}\text { Iljopente } \\
\text { Ilowimbolkt }\end{array}$ & g & 6 & 7 & 17 & 13 & t5 & 0 & 21 & 2] & 0 & $\pi$ & $n$ & 16 & 22 & 20 \\
\hline $\begin{array}{l}\text { Whito } \\
\text { Ilosecebolds }\end{array}$ & 16 & 17 & 16 & 18 & 19 & $\mathbf{t B}$ & 21 & 20 & 201 & 0 & $2 t$ & 24 & 1s & $\geqslant 0$ & 19 \\
\hline
\end{tabular}




\section{APPENDIX A}

\section{TABLE C-1}

\section{ALL LIHEAP-ELIGTEL, HIGH-BURDEN HOUSEHOLDS NATIONAL}

THOUSANDS OF HOUSEFIOLDS

\begin{tabular}{|c|c|c|c|c|c|c|c|c|c|c|c|c|c|c|c|}
\hline \multirow[b]{3}{*}{$\begin{array}{l}\text { Primary } \\
\text { Heating } \\
\text { Fou }\end{array}$} & \multicolumn{12}{|c|}{ Fonsing Tye and Tenure } & & & \multirow[b]{3}{*}{$\begin{array}{l}\text { All } \\
\text { Jlowese } \\
\text { Jlowids }\end{array}$} \\
\hline & \multicolumn{3}{|c|}{ Mobilic flome } & \multicolumn{3}{|c|}{ Shapte Pumity } & \multicolumn{3}{|c|}{ Sinell Multifantlyy } & \multicolumn{3}{|c|}{ 1دم: Mulltimily } & \multicolumn{2}{|c|}{ All Ilowing typer } & \\
\hline & Oms & Reat & $\begin{array}{l}\text { Both } \\
\text { Teoures }\end{array}$ & Ong & Reat & $\begin{array}{l}\text { Eoth } \\
\text { Tenures }\end{array}$ & Own & Reot & $\begin{array}{l}\text { Boch } \\
\text { Teaurrs }\end{array}$ & ama & Real & $\begin{array}{l}\text { Bolh } \\
\text { Tenumes }\end{array}$ & Oma & Rent & \\
\hline Notural Gas & $\mathbf{9}$ & 81 & 173 & 12011 & 7ns & 1,906 & 148 & 642 & 789 & o & tor & $\pi$ & $t, 440$ & 2,131 & $3 s m$ \\
\hline Thoctriely & 8 & to & 19 & 350 & 287 & 67 & 30 & 111 & 140 & D & 457 & $\Delta 7$ & 388 & 865 & 1,254 \\
\hline Fond Oil & 0 & $\mathbf{g}$ & 9 & 631 & 63 & 69 & ss & 169 & 25 & 0 & $\mathbf{2 0 1}$ & mi & 686 & 413 & 1,129 \\
\hline Xerocene & 23 & 3 & 5 & $n$ & 35 & 62 & 0 & 0 & 0 & 0 & $\mathbf{2 0}$ & $\mathbf{2 0}$ & so & 2729 & 178 \\
\hline Propans: & $1 \notin 0$ & 93 & 203 & 389 & 118 & $\mathrm{sen} 7$ & 0 & 0 & 0 & 0 & 0 & 0 & 579 & 211 & 70 \\
\hline Othet Puct: & 31 & 7 & 38 & 157 & 54 & 212 & 0 & 0 & 0 & 0 & 0 & 0 & 188 & 61 & 250 \\
\hline $\begin{array}{l}\text { No Ileating } \\
\text { Ponel Uoed }\end{array}$ & 0 & 0 & 0 & 11 & 38 & 49 & 0 & 19 & 19 & 0 & 0 & 0 & 11 & 58 & $8 B$ \\
\hline All & 34 & 274 & 618 & 2,765 & 1,300 & 10xs & 253 & 91 & 1,173 & 0 & 3,392 & $1,38 n$ & 3,342 & 3,997 & 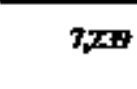 \\
\hline
\end{tabular}




\section{APPENDIX A}

\section{TABLE C-2}

\section{ALL LIHEAP-ELIGIBLE, HIGH-BURDEN HOUSEHOLDS} NATIONAL

\section{PERCANT OF HOUSEGOLDS}

\begin{tabular}{|c|c|c|c|c|c|c|c|c|c|c|c|c|c|c|c|}
\hline \multirow[b]{3}{*}{$\begin{array}{l}\text { Primary } \\
\text { featiogs } \\
\text { Foel }\end{array}$} & \multicolumn{12}{|c|}{ Hoosins Type and Tenure } & & & \multirow[b]{3}{*}{$\begin{array}{l}\text { All } \\
\text { Honses } \\
\text { lloids }\end{array}$} \\
\hline & \multicolumn{3}{|c|}{ Mobile Home } & \multicolumn{3}{|c|}{ Singe Pamily } & \multicolumn{3}{|c|}{ Souall Multitumith } & \multicolumn{3}{|c|}{ Lesg Muldiangy } & \multicolumn{2}{|c|}{ All Itousing Tyes } & \\
\hline & Owd & Reat & $\begin{array}{l}\text { Botb } \\
\text { Tcourst }\end{array}$ & onto & Rะat & $\begin{array}{l}\text { Doth } \\
\text { T=urd }\end{array}$ & Omn & Real & $\begin{array}{l}\text { Both } \\
\text { Tetasurs }\end{array}$ & Orn & Real & $\begin{array}{l}\text { Bouth } \\
\text { Tebures }\end{array}$ & Ono & Rent & \\
\hline Notural Gas & 13 & 1.1 & 24 & 16.6 & 9.7 & 203 & 20 & 6.9 & 10.9 & a.p & 9.7 & 9.7 & 19.9 & 29.4 & 49.3 \\
\hline Dextricity & 0.1 & 0.1 & 0.3 & 4.8 & 4.0 & 20 & 0.4 & is & 1.9 & 0,0 & 6.3 & 6 & $S .4$ & 120 & 173 \\
\hline Tuet Oil & 0.0 & a.1 & 0.6 & 4 & 0.9 & 9.6 & 0.8 & 23 & 3.1 & 0.0 & 28 & 28 & 95 & 61 & 15.6 \\
\hline Kemerept & 03 & 1.0 & 13 & 0.4 & as & 0.9 & Do & 0.0 & 0,0 & 0,0 & 0.3 & 03 & 0.7 & 1.8 & 25 \\
\hline Propape & 26 & 13 & 39 & 5.4 & 16 & 70 & 0.0 & 0.0 & 0.0 & 0.0 & 0.0 & 0.9 & 80 & 29 & 10.9 \\
\hline OLher Pots & 0.4 & 0.1 & os & 22 & a.8 & 29 & and & 0.0 & 0,0 & 0,0 & 0.0 & 0.0 & 26 & 08 & 14 \\
\hline $\begin{array}{l}\text { No llenting } \\
\text { Puel Uleod }\end{array}$ & 0.0 & 0.0 & 0.0 & o.t & os & 0.7 & 0.0 & 0.3 & 03 & 0,0 & 0.0 & 0.0 & 0.1 & 08 & 0.9 \\
\hline All & 48 & 39 & st & 382 & 1100 & $\$ 62$ & 32 & 120 & 162 & 00 & 19,1 & 19.1 & 46.2 & 53.8 & 100.0 \\
\hline
\end{tabular}

Sourse: 1990 Restidential Everby Consumplion Suscy 


\section{APPENDIX A}

\section{TABLE C-3}

\section{ALL WHEAP-ELIGHLE, HIGH-BURDEN HOUSEHOLDS REGIONAL / NORTHEAST}

THOUSAMBS OF hOUSEGOLDS

\begin{tabular}{|c|c|c|c|c|c|c|c|c|c|c|c|c|c|c|c|}
\hline \multirow[b]{3}{*}{$\begin{array}{l}\text { Primny } \\
\text { feating } \\
\text { Foed }\end{array}$} & \multicolumn{12}{|c|}{ Houstan Type and Tenore } & & & \multirow[b]{3}{*}{$\begin{array}{l}\text { All } \\
\text { Ilowte } \\
\text { Ilowts }\end{array}$} \\
\hline & \multicolumn{3}{|c|}{ Mobile Hlome } & \multicolumn{3}{|c|}{ singe Pustily } & \multicolumn{3}{|c|}{ Standl Multifnemily } & \multicolumn{3}{|c|}{ Laş Mutrilanity } & \multicolumn{2}{|c|}{ All flowing Types } & \\
\hline & Own & Reat & $\begin{array}{l}\text { Bodh } \\
\text { Teaurs }\end{array}$ & Ow & Rent & $\begin{array}{l}\text { Bodb } \\
\text { Teoteres }\end{array}$ & Onn & Rent & $\begin{array}{l}\text { Botb } \\
\text { Tequers }\end{array}$ & Dom & Reat & $\begin{array}{l}\text { Both } \\
\text { Tenures }\end{array}$ & Onn & Rent & \\
\hline Nasurat $\mathrm{Glox}$ & 0 & $\mathbf{j 7}$ & 17 & tot & 124 & 20 & 50 & 162 & 212 & 0 & 12 & $\operatorname{tn}$ & 134 & 424 & $s 78$ \\
\hline Esectrikity & 0 & 0 & 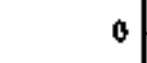 & 0 & 15 & 15 & 0 & 13 & 13 & a & $\leftrightarrow$ & $4 \beta$ & 0 & 76 & 76 \\
\hline Puel oil & o & g & 9 & 244 & 36 & 200 & ss & 15 & $\mathbf{n g}$ & 0 & 201 & 201 & 299 & 400 & 69 \\
\hline Ketoosino & $\boldsymbol{w}$ & 18 & 40 & o & $\mathbf{0}$ & 0 & 0 & 0 & 0 & 0 & 0 & o & $\boldsymbol{z}$ & 18 & 40 \\
\hline \multicolumn{16}{|l|}{ Proplater } \\
\hline Othet Pueks & 0 & 0 & 0 & 17 & 0 & 17 & 0 & 0 & o & 0 & 0 & 0 & 17 & 0 & 17 \\
\hline \multicolumn{16}{|l|}{$\begin{array}{l}\text { No Heating } \\
\text { Puet Used }\end{array}$} \\
\hline Ali & $\mathbf{2 3}$ & 43 & 66 & 365 & 175 & 929 & $\tan$ & $\infty$ & 134 & 0 & $3 \pi$ & $\mathrm{m}$ & 493 & 918 & 1,411 \\
\hline
\end{tabular}


TABLE C-4

\section{AlL LIHEAP-ELIGIBLE, HIGH-BURDEN HOUSEHOLDS REGIONAL / NORTHEAST}

PERCENT OF HOUSEHOLOS

\begin{tabular}{|c|c|c|c|c|c|c|c|c|c|c|c|c|c|c|c|}
\hline \multirow[b]{3}{*}{$\begin{array}{l}\text { Primary } \\
\text { Heating } \\
\text { Foed }\end{array}$} & \multicolumn{12}{|c|}{ Houslne Thpe and Tenare } & & & \multirow[b]{3}{*}{$\begin{array}{l}\text { Alt } \\
\text { Ithores } \\
\text { Ilolds }\end{array}$} \\
\hline & \multicolumn{3}{|c|}{ Moble Howe } & \multicolumn{3}{|c|}{ Single Pratty } & \multicolumn{3}{|c|}{ Small Multifamty } & \multicolumn{3}{|c|}{ Lerge Multinmlly } & \multicolumn{2}{|c|}{ All Howsine Type } & \\
\hline & Owo & $R=01$ & Pool & $O_{\mathrm{wn}}$ & Repl & $\begin{array}{l}\text { Both } \\
\text { Tenutes }\end{array}$ & $O_{m n}$ & Plopal & Tooth & Own & Rept & $\begin{array}{l}\text { Bolb } \\
\text { Teduras }\end{array}$ & Ond & Rent & \\
\hline Naqurat O.s & $\mathbf{a 0}$ & 12 & 12 & 73 & 88 & 16.1 & 36 & tts & เ.1 & 0.0 & 26 & B.6 & 10.9 & 30,1 & 41,9 \\
\hline Exutidity & 0.0 & 0.0 & 0.0 & 0.0 & 1.0 & 10 & 0.0 & 0.9 & 0.9 & 0.0 & 24 & 3,4 & 0.0 & 5.4 & 5.4 \\
\hline Puel Od & 00 & 0.6 & 00 & 173 & 26 & $19:$ & 19 & tong & 148 & all & 143 & 143 & 212 & 28.4 & 495 \\
\hline Kemseose & 1.6 & 12 & 29 & 0.0 & 0.0 & 00 & 00 & wo & 0.0 & 0.0 & 0.0 & $\mathbf{0 . 0}$ & 1.6 & 12 & 29 \\
\hline \multicolumn{16}{|l|}{ Propane } \\
\hline Other Puets & 0.0 & 0.0 & 0.0 & 12 & 0.0 & 12 & 0.0 & 0.0 & 0,0 & 0.0 & 0.0 & 0.0 & t.2 & 0.0 & 12 \\
\hline \multicolumn{16}{|l|}{$\begin{array}{l}\text { No Jleating } \\
\text { Twel Uned }\end{array}$} \\
\hline $\begin{array}{l}\text { All } \\
\text { llowecholdt }\end{array}$ & 16 & 3.1 & 4.7 & 25.9 & 224 & 382 & is & 203 & 302 & 0.0 & 263 & 26.3 & 34.9 & 65.1 & 1000.0 \\
\hline
\end{tabular}




\section{APPENDIX A}

TABLE C-5

\section{ALL LIHEAP-ELIGIBLE, HIGH-BURDEN HOUSEHOLDS REGIONAL / MIDWEST}

\section{THOUSANDS OF HOUSEHOLDS}

\begin{tabular}{|c|c|c|c|c|c|c|c|c|c|c|c|c|c|c|c|}
\hline \multirow[b]{3}{*}{$\begin{array}{l}\text { Primnry } \\
\text { lleating: } \\
\text { Poel }\end{array}$} & \multicolumn{12}{|c|}{ Hoosing Type and Tennre } & & & \multirow[b]{3}{*}{$\begin{array}{l}\text { Alt } \\
\text { flow:t } \\
\text { flolds }\end{array}$} \\
\hline & \multicolumn{3}{|c|}{ Mobtio Hoono } & \multicolumn{3}{|c|}{ Sinfle Pamily } & \multicolumn{3}{|c|}{ Small Multiftarily } & \multicolumn{3}{|c|}{ Lero Mulifamily } & \multicolumn{2}{|c|}{ All Ilowsing Typs } & \\
\hline & Own & Reat & $\begin{array}{l}\text { Bolb } \\
\text { Tenards }\end{array}$ & Ons & Reas & $\begin{array}{l}\text { Botb } \\
\text { Ttenures }\end{array}$ & Ond & Real & $\begin{array}{l}\text { Botb } \\
\text { Teaurs }\end{array}$ & Owo & Reat & $\begin{array}{l}\text { Boeb } \\
\text { Tenteres }\end{array}$ & Oenn & Rteat & \\
\hline Natural Ges & $\mathrm{s}$ & 11 & 19 & M7 & 291 & $\mathbf{a 1}$ & 75 & in & $\mathbf{5} \mathbf{2}$ & 0 & 53 & 53 & 430 & 534 & 964 \\
\hline एectridty & 6) & 0 & 8 & 34 & 0 & $\boldsymbol{3}$ & a) & 0 & o & 0 & 8 & $\mathbf{s}$ & 13 & 8 & so \\
\hline Thes ot & 0 & 0 & 0 & 199 & 8 & 200 & $\mathbf{0}$ & 26 & 16 & 0 & 0 & 0 & 199 & 24 & $m$ \\
\hline Kerocene & 0 & 0 & 0 & 0 & 0 & $\mathbf{0}$ & a & 0 & $\mathbf{0}$ & 0 & $n$ & $\mathbf{2 0}$ & o & $\mathbf{n}$ & 20 \\
\hline Poppare & 53 & 35 & $\mathrm{BB}$ & 13 & 38 & 27 & 0 & 0 & o & 0 & o & 0 & 291 & 73 & 264 \\
\hline Otber livet & 31 & 7 & 39 & 20 & 16 & 36 & 0 & 0 & o) & 0 & 0 & 0 & 31 & $\mathbf{2 3}$ & 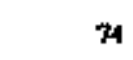 \\
\hline 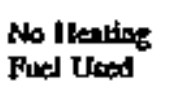 & & & & & & & & & & & & & & & \\
\hline All & 100 & st & 154 & 739 & 355 & 1,094 & $\pi$ & 193 & $2 \times 8$ & 0 & 80 & $\$$ & 914 & $\Delta<2$ & 15\%5 \\
\hline
\end{tabular}




\section{APPENDIX A \\ TABLE C-6 \\ ALL LIHEAP-ELIGIBLE, HIGH-BURDEN HOUSEHOLDS REGIONAL / MIDWEST}

\section{PERCENT OF HOUSEHOLDS}

\begin{tabular}{|c|c|c|c|c|c|c|c|c|c|c|c|c|c|c|c|}
\hline \multirow[b]{3}{*}{$\begin{array}{l}\text { Primary } \\
\text { Heating } \\
\text { Foel }\end{array}$} & \multicolumn{12}{|c|}{ Housins Type and Temare } & & & \multirow[b]{3}{*}{$\begin{array}{l}\text { All } \\
\text { Housce } \\
\text { IIolds }\end{array}$} \\
\hline & \multicolumn{3}{|c|}{ Moble llome } & \multicolumn{3}{|c|}{ Single themity } & \multicolumn{3}{|c|}{ Small Multòlamily } & \multicolumn{3}{|c|}{ 1ars Multibamily } & \multicolumn{2}{|c|}{ Al Itowang Types } & \\
\hline & Ont & Heot & $\begin{array}{l}\text { Bolk } \\
\text { Teauts: }\end{array}$ & ons & R:ot & $\begin{array}{l}\text { Dotb } \\
\text { Tenurea }\end{array}$ & Oms & Rent & $\begin{array}{l}\text { Bolt } \\
\text { Tequers }\end{array}$ & Owo & Rent & $\begin{array}{l}\text { Both } \\
\text { Tenurs }\end{array}$ & Om & Rrat & \\
\hline Natural Oas & as & 0.7 & 12 & 21.8 & 18,1 & 402 & 4.7 & t3.5 & IS, B & 00 & 33 & 3.3. & $2 \times 9$ & 335 & 60.4 \\
\hline Latrichly & 0,5 & 0.0 & os & 21 & 0.0 & 21 & $\mathbf{0 . 0}$ & a., 0 & 0.0 & 00 & os & os & 27 & 0.5 & 32 \\
\hline Puel ois & 0.0 & 0.0 & 0.0 & tos & a.s & 130 & 0,0 & 1.0 & 1.0 & 00 & 0.0 & 0.0 & us & 15 & 14.0 \\
\hline Kefoestase & 0.0 & 0.0 & 0.0 & 00 & 0,0 & 0.0 & 0,0 & 0.0 & 0.0 & 0.0 & 12 & 1.2 & 0.0 & 12 & 12 \\
\hline Propane & 33 & 22 & ss & 87 & 24 & 11,0 & 0,0 & 0.0 & 0.0 & 0.0 & 0.0 & 0.0 & 120 & 4.6 & 166 \\
\hline Other Puebs & 1.9 & 0.4 & 24 & 12 & 1,0 & 22 & 0,0 & 0.0 & 0.0 & 0.0 & 0.0 & 0.0 & 32 & 1.4 & 4.6 \\
\hline \multicolumn{16}{|l|}{$\begin{array}{l}\text { No flenting } \\
\text { Fuel Uleed }\end{array}$} \\
\hline Aloustbokts & 63 & 34 & 9.6 & 46.3 & ב & 6B & 4.7 & 121 & 168 & 0.0 & S.o & 5.0 & 573 & 127 & 1000 \\
\hline
\end{tabular}




\section{APPENDIX A}

\section{TABLE C-7}

\section{AL.L LIHEAP-ELIGIBLE, HIGH-BURDEN HOUSEHOLDS REGIONAL / SOUTH}

\section{THOUSANDS OF HOUSEHOLAS}

\begin{tabular}{|c|c|c|c|c|c|c|c|c|c|c|c|c|c|c|c|}
\hline \multirow[b]{3}{*}{$\begin{array}{l}\text { Prinang } \\
\text { fieating } \\
\text { Fuel }\end{array}$} & \multicolumn{12}{|c|}{ Honsint Type and Tenure } & & & \\
\hline & \multicolumn{3}{|c|}{ Mobste Howe } & \multicolumn{3}{|c|}{ Sinte Pamily } & \multicolumn{3}{|c|}{ Sonalt Muftifumily } & \multicolumn{3}{|c|}{ 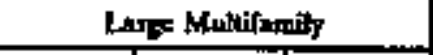 } & \multicolumn{2}{|c|}{ As tlowing Types } & \multirow[b]{2}{*}{$\begin{array}{l}\text { All } \\
\text { Houns } \\
\text { lboits }\end{array}$} \\
\hline & Ons & Rad & $\begin{array}{l}\text { Botb } \\
\text { Tenstes }\end{array}$ & Omg & Fent & $\begin{array}{l}\text { Both } \\
\text { Tepures }\end{array}$ & Omin & Rent & $\begin{array}{l}\text { Boch } \\
\text { Teawis: }\end{array}$ & Ows & Pent & $\begin{array}{l}\text { Bolb } \\
\text { Teouras }\end{array}$ & Own & Rept & \\
\hline Natural $G$ & 23 & 17 & 40 & $\$ \mathbf{H 7}$ & 145 & 692 & $n$ & 205 & 227 & o & 27 & $m$ & $\$ 92$ & 638 & 1,230 \\
\hline Dectriscily & 0 & 0 & 0 & 213 & 130 & 343 & 0 & 42 & 42 & 0 & 296 & 296 & 253 & 468 & $64 t$ \\
\hline Puel Oil & 0 & 0 & 0 & 189 & 19 & 207 & 0 & a & $\mathbf{0}$ & 0 & $\mathbf{0}$ & a & 188 & 19 & 207 \\
\hline Kersenenc & 0 & 56 & 56 & $n$ & 35 & 62 & 0 & 0 & 0 & o & 0 & 0 & $n$ & 91 & 118 \\
\hline Propene & 105 & 46 & 152 & 19 &, 52 & 245 & 0 & 0 & o & 0 & 0 & $\mathbf{0}$ & 299 & 97 & 398 \\
\hline Olber Pies: & 0 & 0 & o & 4 & $\mathbf{n}$ & 69 & 0 & 0 & 0 & o & 0 & 0 & 45 & 23 & 68 \\
\hline \multicolumn{16}{|l|}{$\begin{array}{l}\text { No Iteatint } \\
\text { Poel Uneed }\end{array}$} \\
\hline All & 128 & 119 & 267 & 1,274 & 401 & 1,518 & 2 & 213 & 260 & 0 & 566 & 566 & 1,364 & 1,36 & $2 \pi 4$ \\
\hline
\end{tabular}




\section{APPENDIX A}

\section{TABLE C-8}

\section{ALL LHEAP-ELIGIBLE, HIGH-BURDEN HOUSEHOLDS REGIONAL / SOUTH}

PERCENT OF HOUSEHOLDS

\begin{tabular}{|c|c|c|c|c|c|c|c|c|c|c|c|c|c|c|c|}
\hline \multirow[b]{3}{*}{$\begin{array}{l}\text { Pringy } \\
\text { Fentine } \\
\text { Pnet }\end{array}$} & \multicolumn{12}{|c|}{ Hoaglise Type and Teuare } & & & \multirow[b]{3}{*}{$\begin{array}{l}\hat{A}^{N} \\
\text { Howese } \\
\text { llokst }\end{array}$} \\
\hline & \multicolumn{3}{|c|}{ Mobile Howne } & \multicolumn{3}{|c|}{ Suple Panolyy } & \multicolumn{3}{|c|}{ Sondl Multifamily } & \multicolumn{3}{|c|}{ Lage Multumily } & \multicolumn{2}{|c|}{ All Houneng Typer } & \\
\hline & Own & Rent & $\begin{array}{l}\text { Both } \\
\text { Texistes }\end{array}$ & Omn & Real & $\begin{array}{l}\text { Doth } \\
\text { Teaums: }\end{array}$ & Onm & Perat & $\begin{array}{l}\text { Both } \\
\text { Teauses }\end{array}$ & Om & Reat & $\begin{array}{l}\text { Both } \\
\text { Teaures }\end{array}$ & ONn & Reat & \\
\hline Nalurnt Gas & os & 0.6 & 1.5 & 20,2 & 5.4 & 25.6 & 0.8 & 76 & 84 & 0.0 & 10.0 & 10.0 & 21.9 & $\mathbf{2 . 6}$ & t5s \\
\hline Dlectrixtity & $\infty .0$ & 0.0 & 0.0 & 7.9 & 14 & 127 & $0 ; 0$ & 1.6 & t.s & 0.0 & 10.9 & 10.9 & 7,9 & 173 & $\mathbf{x}$ \\
\hline Pivet ois & 0.0 & 0.0 & 0.0 & 20 & 0.7 & 7.7 & 0.0 & $\infty 0$ & 0.0 & 0.0 & 0.0 & 0.0 & $\mathbf{3 . 0}$ & 0.7 & 7.7 \\
\hline Keroecde & oo & 21 & 21 & 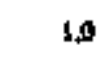 & 13 & 23 & 0.0 & 0.0 & $\infty .0$ & 0.0 & 0.0 & 0.0 & 1.0 & 3.4 & 44 \\
\hline Propane & 3.9 & 1.7 & 5.6 & 72 & 1.9 & 9.1 & 0.0 & 20 & 0.0 & 0.0 & 00 & 0.0 & 11.1 & 3.7 & 14.7 \\
\hline Othet Puets & 0.0 & 0.0 & 0.0 & 17 & 0. & 25 & 0.0 & 0.0 & 0.0 & 0.0 & 0.0 & 0.0 & 1.7 & $0 . B$ & 25 \\
\hline 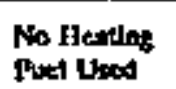 & & & & - & & & & & & & & & & & \\
\hline $\begin{array}{l}\text { All } \\
\text { llowebolks: }\end{array}$ & 4.7 & $A$ & 92 & $\mathbf{0 . 0}$ & 18.0 & 97.9 & 09 & 9.1 & 10.0 & a.to & 21.0 & 21.0 & sos & 495 & 1000 \\
\hline
\end{tabular}




\section{APPENDIX A}

\section{TABLE C-9}

\section{ALL LIHEAP-ELIGIBLE, HIGH-BURDEN HOUSEHOLDS REGIONAL / WEST}

\section{THOUSANDS OF HOUSEHOLDS}

\begin{tabular}{|c|c|c|c|c|c|c|c|c|c|c|c|c|c|c|c|}
\hline \multirow[b]{3}{*}{$\begin{array}{l}\text { Primary } \\
\text { flestime } \\
\text { Fand }\end{array}$} & \multicolumn{12}{|c|}{ Honalias Type and Tenare } & & & \multirow[b]{3}{*}{$\begin{array}{l}\text { All } \\
\text { Fouses } \\
\text { tlotsts }\end{array}$} \\
\hline & \multicolumn{3}{|c|}{ Nobilo llowe } & \multicolumn{3}{|c|}{ Sing Pamily } & \multicolumn{3}{|c|}{ Smatll Mulififumily } & \multicolumn{3}{|c|}{ Lorge Multilmpilly } & \multicolumn{2}{|c|}{ An I lowsing Typ=t } & \\
\hline & Owa & Fent & $\begin{array}{l}\text { Both } \\
\text { Teopres }\end{array}$ & Ond & Reot & $\begin{array}{l}\text { Both } \\
\text { Tenure }\end{array}$ & Den & Renl & $\begin{array}{l}\text { Both } \\
\text { Tenores }\end{array}$ & Ono & Ptat & $\begin{array}{l}\text { Dotb } \\
\text { Tertrms: }\end{array}$ & Onn & Reat & \\
\hline Natural Gas & $\tilde{\mathbf{n}}$ & $n$ & 9 & 203 & 142 & 30 & $\mathbf{0}$ & 99 & 98 & 0 & 39 & 259 & 2ass & 535 & 800 \\
\hline Electricity & 0 & 10 & 10 & 103 & 143 & 215 & $\mathbf{3 0}$ & ss & es & 0 & 106 & 106 & 133 & 314 & 417 \\
\hline \multicolumn{16}{|l|}{ Mot Oat } \\
\hline \multicolumn{16}{|l|}{ Xorosenc } \\
\hline Propane & $\mathbf{n}$ & 11 & +3 & 56 & .28 & BS & 01 & 0 & $\mathbf{0}$ & 0 & D & 0 & 88 & 39 & 27 \\
\hline Olter Puets & 0 & 0 & 0 & $\boldsymbol{r}$ & 16 & 91 & a & 0 & 0 & 0 & 0 & 0 & 75 & 16 & 91 \\
\hline $\begin{array}{l}\text { No Heatiog } \\
\text { Puet Uned }\end{array}$ & o & 0 & o & 11 & 38 & 19 & * & t9 & 19 & 0 & 0 & 0 & נ1 & 58 & 6 \\
\hline $\begin{array}{l}\text { Al } \\
\text { Etousebolks }\end{array}$ & का & $\mathbf{s g}$ & $\mathbf{s 1}$ & 48 & 366 & B14 & 30 & 172 & $m$ & 0 & 365 & $3 \mathbf{s} 5$ & sn & $\mathbf{9 6 1}$ & 1,573 \\
\hline
\end{tabular}




\section{APPENDIX A}

\section{TABLE C-10}

\section{ALL LHEAP-ELIGIBLE, HIGH-BURDEN HOUSEHOLDS REGIONAL / WEST}

PERCENT OF HOUSEHOLDS

\begin{tabular}{|c|c|c|c|c|c|c|c|c|c|c|c|c|c|c|c|}
\hline \multirow[b]{3}{*}{$\begin{array}{l}\text { Primary } \\
\text { Peationg } \\
\text { Foel }\end{array}$} & \multicolumn{12}{|c|}{ Hooutas Type and 'Tenure } & & & \multirow[b]{3}{*}{ 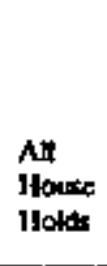 } \\
\hline & \multicolumn{3}{|c|}{ Mobike Hlome } & \multicolumn{3}{|c|}{ Single Pamily } & \multicolumn{3}{|c|}{ Sonat Multtramily } & \multicolumn{3}{|c|}{ Lapo Multiramity } & \multicolumn{2}{|c|}{ An Ilowing Type: } & \\
\hline & Ond & Reol & $\begin{array}{l}\text { Bosh } \\
\text { Tetures }\end{array}$ & Ond & Reat & $\begin{array}{l}\text { Notb } \\
\text { Teatres }\end{array}$ & Omo & Real & $\begin{array}{l}\text { Both } \\
\text { Teterex }\end{array}$ & Omn & Fteal & $\begin{array}{l}\text { Bosh } \\
\text { Tenores }\end{array}$ & Owe & Fral & \\
\hline Malural Gas & 40 & 2.4 & 64 & 133 & 92 & 225 & 0 & 64 & 84 & & 169 & 16,9 & 173 & 349 & 522 \\
\hline Eextraily & 0 & $?$ & .7 & 6.7 & 93 & 16 & 20 & 36 & s.6 & & 69 & 69 & 27 & 2015 & 29.1 \\
\hline Puel oil & & & & & & & & & & & & & & & \\
\hline Kerocenoe & & & & & & & & & & & & & & & \\
\hline Propade & 21 & 7 & 28 & 3.7 & 1.8 & is & 0 & 0 & 0 & $\mathbf{0}$ & 0 & 0 & 58 & 26 & 83 \\
\hline Ouber Puads & 0 & 0 & 0 & 4.9 & 1.0 & S.9 & 0 & 0 & 0 & 0 & 0 & 0 & 19 & 1.0 & 5.5 \\
\hline $\begin{array}{l}\text { No I lewlins } \\
\text { Puxl Uited }\end{array}$ & 0 & 0 & 0 & .7 & 25 & 32 & 0 & 13 & 13 & 0 & 0 & 0 & .7 & $3 s$ & 45 \\
\hline $\begin{array}{l}\text { All } \\
\text { Houreholds }\end{array}$ & 6.] & 38 & 9.9 & 29.2 & 239 & $53 . t$ & 2 & 112 & 132 & 0 & $\mathbf{2 3 . 3}$ & 233 & $n 3$ & 627 & 100.0 \\
\hline
\end{tabular}




\section{APPENDIX A}

TABLE C-1I

\section{ALL LIHEAP-ELIGIBLE, HIGH-BURDEN HOUSEHOLDS NATIONAL}

\section{MEAN RESIDENTTAL ENERGY EXPENDTTURES IN CURRENT DOLARS}

\begin{tabular}{|c|c|c|c|c|c|c|c|c|c|c|c|c|c|c|c|}
\hline \multirow[b]{3}{*}{$\begin{array}{l}\text { Priming } \\
\text { Heatinis } \\
\text { Fael }\end{array}$} & \multicolumn{12}{|c|}{ Housing Type and Teoure } & & & \multirow[b]{3}{*}{$\begin{array}{l}\text { All } \\
\text { Ilonese } \\
\text { I loids }\end{array}$} \\
\hline & \multicolumn{3}{|c|}{ Mobile tlome } & \multicolumn{3}{|c|}{ Singe thenily } & \multicolumn{3}{|c|}{ Small Motrifamily } & \multicolumn{3}{|c|}{ Lare Matifamily } & \multicolumn{2}{|c|}{ AI Jlousing Jypes } & \\
\hline & Own & Ren1 & $\begin{array}{l}\text { Dotb } \\
\text { Teaures }\end{array}$ & Om & Read & $\begin{array}{l}\text { 1alh } \\
\text { Tktures }\end{array}$ & Owo & Reat & $\begin{array}{l}\text { గolth } \\
\text { Tehur= }\end{array}$ & Oma & Reat & $\begin{array}{l}\text { Bokb } \\
\text { Temures }\end{array}$ & Omn & Real & \\
\hline Naturd Gar & 621 & 99 & 78 & 1,349 & 1,755 & 1552 & 1,74 & ms & 1,12 & $\mathbf{0}$ & 72 & $\pi$ & 1,346 & 1,017 & $1,1+0$ \\
\hline Dlectrikity & $1 \mathrm{~g} 7 \mathrm{~s}$ & 76 & itה? & 1,252 & 994 & 2,135 & $8 \mathbf{3 7}$ & sts & 843 & 0 & 74 & 74 & $t, 23$ & 89 & 95 \\
\hline Iuel Oil & 0 & 2,044 & 2,044 & 1,174 & $1, m$ & $t, 4 n$ & 2,275 & $1,2 * 3$ & $1,4 \%$ & D & 1,051 & $\$, 061$ & 1,539 & 1241 & 1,60 \\
\hline Kerocedec & 1,353 & 692 & 997 & 690 & 2,410 & 1,34 & 0 & 0 & 4 & 0 & 364 & 364 & 1,009 & 1,275 & 1,185 \\
\hline Propape & 1,435 & 1,390 & $t, 420$ & 1399 & Bta & 1,27 & 0 & 0 & 0 & D & 0 & o & 2,411 & 1,087 & !,324 \\
\hline Other l'uels: & 1,237 & $93:$ & \&,LBI & 900 & $1,(210)$ & $\%$ & 0 & 0 & 0 & 0 & 0 & 0 & 989 & 1,022 & $m$ \\
\hline $\begin{array}{l}\text { No Iteatias } \\
\text { Rucl Utods }\end{array}$ & o & 0 & 0 & 1,240 & 1,526 & 1,464 & 0 & $1,0 \times 9$ & 1 If:98 & 0 & 0 & 0 & 1,240 & 1,360 & 1,34 \\
\hline $\begin{array}{l}\text { A: } \\
\text { linosebolds }\end{array}$ & $1,2 \mathrm{~m}$ & 1,124 & 1,169 & 1,34 & 1,261 & 1,320 & $1, m$ & $1, \infty 0$ & 1,159 & 0 & zss & 765 & 1,359 & 1,017 & 1,175 \\
\hline
\end{tabular}


APPENDIX A

\section{TABLE C-12}

\section{ALL LIHEAP-ELIGIBLE, HIGH-BURDEN HOUSEHOLDS NATIONAL}

\section{STANDARD DEVATTON OF MEAN EXPENDS. N CURRENT DOLLARS}

\begin{tabular}{|c|c|c|c|c|c|c|c|c|c|c|c|c|c|c|c|}
\hline \multirow[b]{3}{*}{$\begin{array}{l}\text { Primnry } \\
\text { listling } \\
\text { Finel }\end{array}$} & \multicolumn{12}{|c|}{ Elonsing Type and Tenure } & & & \multirow[b]{3}{*}{$\begin{array}{l}\text { All } \\
\text { llowes } \\
\text { llotit }\end{array}$} \\
\hline & \multicolumn{3}{|c|}{ Mobile Hoone } & \multicolumn{3}{|c|}{ Sinde Pumily } & \multicolumn{3}{|c|}{ Somall Mulutirnmily } & \multicolumn{3}{|c|}{ Large Mualifumily } & \multicolumn{2}{|c|}{ All tousting Types } & \\
\hline & Om & Peat & $\begin{array}{l}\text { Both } \\
\text { Tebutes }\end{array}$ & Own & Rent & $\begin{array}{l}\text { Bot } \\
\text { Teaures }\end{array}$ & Owo & Reat & $\begin{array}{l}\text { Both } \\
\text { Teduree }\end{array}$ & Onn & Reat & $\begin{array}{l}\text { Booth } \\
\text { Teounes }\end{array}$ & Own & Renl & \\
\hline Natused ats & 236 & 412 & $\mathbf{s}$ & $5 \% 6$ & 158 & 536 & 57 & 393 & 535 & 0 & $27 s$ & 275 & 606 & 46 & sso \\
\hline Doxtricity & 0 & a. & 578 & 495 & 400 & 473 & 108 & 232 & 212 & 0 & 337 & 337 & 493 & 368 & $4 \$ 1$ \\
\hline Put on & 0 & o & o & $5+6$ & 759 & 599 & $s 7$ & 206 & 586 & 0 & $m$ & 478 & 615 & 535 & 60 \\
\hline Kenoedec & 58 & $\mathbf{2 0}$ & $2 \pi$ & 0 & $n$ & 1,056 & 0 & 0 & 0 & 0 & $\mathbf{0}$ & 0 & 20 & 924 & 795 \\
\hline Prepant & 412 & 519 & 16 & 564 & 69 & 347 & 0 & 0 & 0 & 4 & 0 & 0 & 527 & 140 & S2S \\
\hline Other Puck & 0 & 0 & 117 & 54 & $5 \& a$ & 556 & 0 & 0 & 0 & 0 & 0 & 0 & SOS & 548 & 519 \\
\hline $\begin{array}{l}\text { No Ilenting } \\
\text { Poxal Usat }\end{array}$ & 0 & 0 & 0 & 0 & 300 & 37 & 0 & 350 & 350 & 0 & 0 & 0 & 0 & 436 & 404 \\
\hline $\begin{array}{l}\text { All } \\
\text { Ilousetholds }\end{array}$ & 505 & 483 & 49 & 574 & 555 & $S \notin B$ & $68 \mathrm{t}$ & 379 & 548 & 0 & 3 & 354 & 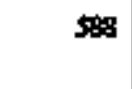 & 492 & 565 \\
\hline
\end{tabular}


APPENDIX A

TABLE C-13

\section{ALL LHEAP-ELIGIBLE, HIGH-BURDEN HOUSEHOLDS NATIONAL}

MEAN ANNUAL CASH TRCOME

\begin{tabular}{|c|c|c|c|c|c|c|c|c|c|c|c|c|c|c|c|}
\hline \multirow[b]{3}{*}{$\begin{array}{l}\text { Prinary } \\
\text { Heating } \\
\text { Shet }\end{array}$} & \multicolumn{11}{|c|}{ Howsint Type and Tenters } & & & & \multirow[b]{3}{*}{$\begin{array}{l}\text { All } \\
\text { Ifoute } \\
\text { Holds }\end{array}$} \\
\hline & \multicolumn{3}{|c|}{ Mabile Jlome } & \multicolumn{3}{|c|}{ Stange Pamily } & \multicolumn{3}{|c|}{ Swaln Multìnily } & \multicolumn{3}{|c|}{ Lage Multilanily } & \multicolumn{2}{|c|}{ All Housteg Types } & \\
\hline & Owo & Feat & $\begin{array}{l}\text { Both } \\
\text { Tepares }\end{array}$ & Onn & Reat & $\begin{array}{l}\text { Boch } \\
\text { Tenufz: }\end{array}$ & Don & Ren! & $\begin{array}{l}\text { Both } \\
\text { Teabues }\end{array}$ & Om & ONn & $\begin{array}{l}\text { Boch } \\
\text { Tedures }\end{array}$ & Owat & Rtot & \\
\hline Nutural ats & 4 & 4,469 & 4,658 & 6,599 & 6,955 & 6,731 & 6,746 & $\mathbf{3 , 9 4 ?}$ & 1,470 & 0 & 4,000 & 4,030 & 6,001 & 4,988 & 5,59 \\
\hline Dlectricily & 8,70 & 5,500 & 6,700 & $5, \pi !$ & 3,480 & $1, \pi 5$ & 5,990 & 3,736 & 4,216 & 0 & 3,496 & 3,496 & 5,788 & 6,545 & 4;,40 \\
\hline Pact Oit & o & 9:500 & 9,500 & 7,006 & 7872 & 3,000 & 8,74 & 3,002 & 4,749 & 0 & 2751 & 2,51 & 7,108 & 3,939 & 5,865 \\
\hline Keroceac & 2,58 & 2,000 & 2,239 & 5,500 & 6,098 & 5,839 & $\mathbf{0}$ & 0 & 0 & 0 & 1,500 & 1,500 & 4,341 & 3,046 & 3,409 \\
\hline Propene & 7,72 & 4,905 & 6,7 & 5,854 & 2,609 & 5,107 & 0 & 0 & 0 & 0 & 0 & 0 & 6,474 & $6,62:$ & $5, \pi 2$ \\
\hline Other Pueks & 5,500 & 3,500 & 5.124 & 5,103 & SRM & 5,283 & a & 0 & 0 & 0 & 0 & 0 & 5,169 & 5,535 & 5,259 \\
\hline $\begin{array}{l}\text { No Henting } \\
\text { Pued Upard }\end{array}$ & 0 & 0 & 0 & 11,750 & 14,6121 & 14,011 & 0 & $9, \pi 4$ & $9,72 A$ & 0 & 0 & 0 & 11,700 & 13,992 & 12,800 \\
\hline All & 6,46 & 4,136 & $5,12 n$ & 6,400 & 5,993 & $6,2 \pi$ & 7,011 & 197 & 1,57 & 0 & 3,600 & 3,690 & 6,417 & 4,538 & 5,419 \\
\hline
\end{tabular}




\section{APPENDIX A}

\section{TABLE C-14}

\section{ALL LIHAAP-ELIGIBLE, HIGH-BURDEN HOUSEHOLDS NATIONAL}

MEAN ENERGY BURDEN - EXPENDITURISS AS \% OF INCOME

\begin{tabular}{|c|c|c|c|c|c|c|c|c|c|c|c|c|c|c|c|}
\hline \multirow[b]{3}{*}{$\begin{array}{l}\text { Priminy } \\
\text { Ileationg } \\
\text { Fued }\end{array}$} & \multicolumn{12}{|c|}{ Hoostes Type and Teadre } & & & \multirow[b]{3}{*}{$\begin{array}{l}\text { All } \\
\text { Howso } \\
\text { Illowk }\end{array}$} \\
\hline & \multicolumn{3}{|c|}{ Mobilte Howe } & \multicolumn{3}{|c|}{ Slape Panily. } & \multicolumn{3}{|c|}{ Small Multifnaily } & \multicolumn{3}{|c|}{ Lese Mnltwamily } & \multicolumn{2}{|c|}{ All Housing Types } & \\
\hline & Oma & Reat & $\begin{array}{l}\text { Bolh } \\
\text { Tetoortat }\end{array}$ & $0 m$ & Reat & $\begin{array}{l}\text { Both } \\
\text { Teturas }\end{array}$ & Om & Rem & $\begin{array}{l}\text { Both } \\
\text { Tentires }\end{array}$ & ONo & Real & $\begin{array}{l}\text { Bolt } \\
\text { Tenores }\end{array}$ & Oms & Rent & \\
\hline Nalera Cos & $\mathbf{5 . 9}$ & 277 & $2 a A$ & $2 \times 6$ & 322 & 20,7 & 2as & 356 & $\mathbf{3 3}$ & 0 & 21.9 & 24.9 & \$.1 & 30.7 & 288 \\
\hline Electricity & 28 & 130 & 17.4 & 28.6 & 37.6 & 31.0 & 14,9 & 52 & 30.9 & 0 & 30.9 & 30.9 & 24.7 & 335 & $\mathbf{s}$ \\
\hline Pud Oil & 0 & $2 t s$ & 215 & $\not 3$ & 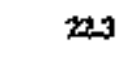 & 2Ko & 伍: & 456 & 46 & 0 & 50.6 & 50.6 & 26.8 & $\$ 52$ & u. \\
\hline Kerosente & 663 & $\$ 14$ & 51.9 & 16.0 & 46.3 & 33.1 & a & 0 & 0 & 0 & 243 & 243 & 39.1 & 43.5 & $\mathbf{2 3}$ \\
\hline Propape & 2014 & 292 & $\mathbf{3} 2$ & 332 & 385 & 345 & 0 & 0 & o & 0 & $\mathbf{0}$ & a & $\mathbf{2 0 0}$ & 34.4 & 305 \\
\hline Other Thets & 25 & 20 & $23 \sqrt{3}$ & 26.1 & 17,0 & 238 & 0 & 0 & 0 & 0 & 0 & 0 & t5s & 18.1 & 20.7 \\
\hline $\begin{array}{l}\text { No Ileating } \\
\text { Puel Ulaterl }\end{array}$ & a & 0 & 0 & 106 & $\mathbf{t 2 0}$ & 11.7 & 0 & 11.4 & $11 / 4$ & 0 & 0 & o & 10.6 & 118 & 11.6 \\
\hline $\begin{array}{l}\text { All } \\
\text { Housebolds }\end{array}$ & $n s$ & 327 & xtin & $n+1$ & t27 & 289 & 27.7 & 37.4 & 255 & 0 & 306 & 30.6 & $\mathbf{2 0}$ & 30.1 & $\mathbf{3 0}, \mathbf{t}$ \\
\hline
\end{tabular}


$\because \cdot \therefore: \quad \therefore \quad \therefore=$

$\therefore \quad \therefore \quad \therefore-\frac{1}{4}=$

\section{APPENDIX A}

TABLE C-15

ALL LIHFAP-ELIGIBLE, HIGH-BURDEN HOUSEHOLDS BY PROGRAM PARTICIPATION NATIONAL

THOUSANDS OF HOUSEHOLDS

\begin{tabular}{|c|c|c|c|c|c|c|c|c|c|c|c|c|c|c|}
\hline & \multicolumn{11}{|c|}{ Housing Type and Tenure } & & & \multirow[b]{3}{*}{$\begin{array}{l}\text { All } \\
\text { Hoose- } \\
\text { lloids }\end{array}$} \\
\hline & \multicolumn{3}{|c|}{ Mobile Home } & \multicolumn{3}{|c|}{ Single Pronily } & \multicolumn{3}{|c|}{ Smnil Maltiframily } & \multicolumn{2}{|c|}{ Letac Multilamily } & \multicolumn{2}{|c|}{ All Elowing Types } & \\
\hline & Oma & Rent & $\begin{array}{l}\text { Both } \\
\text { Tenures }\end{array}$ & Oms & Rent & $\begin{array}{l}\text { Botb } \\
\text { Tentries }\end{array}$ & Omm & Rent & $\begin{array}{l}\text { Hoth } \\
\text { Tengirat }\end{array}$ & Reat & $\begin{array}{l}\text { Both } \\
\text { Tenores }\end{array}$ & Omo & Altent & \\
\hline 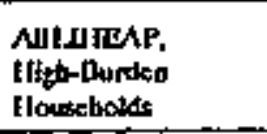 & 344 & 274 & 618 & 2,765 & 1,300 & 4,065 & 203 & sit & 1,173 & 1,382 & 1,382 & 3,342 & 3,897 & 7,230 \\
\hline AFDCReciplents & $\Leftrightarrow$ & 111 & 192 & 188 & (6898 & 666 & $\mathbf{0}$ & 302 & 380 & 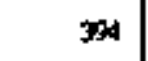 & 394 & $\$ 9$ & 1,375 & 5,634 \\
\hline S\$I Retipkenle & sg & 36 & \$ & 278 & 100 & 339 & 11 & 100 & 117 & LS & $\mathbf{L s}$ & $\mathbf{3 0 8}$ & 399 & 207 \\
\hline 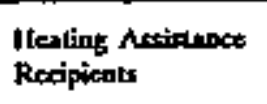 & 125 & ins & 200 & $\sin$ & 46 & 946 & $\mathbf{x y}$ & 213 & 242 & $2 \infty$ & 206 & $6 \mathbf{4}$ & 991 & 1,645 \\
\hline $\begin{array}{l}\text { Rood stump } \\
\text { Rexipients }\end{array}$ & 实 & 158 & 266 & $\Delta 2$ & 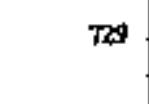 & 1,181 & 11 & $4 \%$ & 500 & 465 & 465 & S61 & 1,848 & 2,409 \\
\hline $\begin{array}{l}\text { Uoemployment } \\
\text { Compensation }\end{array}$ & 0 & D & 0 & 67 & D & 67 & 29 & 0 & 29 & 30 & 30 & 86 & 30 & 127 \\
\hline $\begin{array}{l}\text { Subcidined } \\
\text { Howeser }\end{array}$ & : & 43 & 13 & 0 & 158 & 158 & 0 & 167 & 167 & $\pm x$ & $\infty$ & $n$ & $\cdots$ & \\
\hline
\end{tabular}


- 1 APPENDIX A

TABLE C-16

ALL LIHEAP-ELIGIBLE, HIGH-BURDEN HOUSEHOLDS BY PROGRAM PARTICIPATION NATTONAL

\section{PERCENT OF HOUSEHTOLS}

\begin{tabular}{|c|c|c|c|c|c|c|c|c|c|c|c|c|c|c|}
\hline \multirow{3}{*}{. } & \multicolumn{11}{|c|}{ Ilonsiby Type and Teure } & & & \multirow[b]{3}{*}{$\begin{array}{l}\text { All } \\
\text { Houst- } \\
\text { Holds }\end{array}$} \\
\hline & \multicolumn{3}{|c|}{ Mobile Itome } & \multicolumn{3}{|c|}{ Singe Pamily } & \multicolumn{3}{|c|}{ Smenll Mullǘnmily } & \multicolumn{2}{|c|}{ IARS Mutifamity } & \multicolumn{2}{|c|}{$\begin{array}{l}\text { All Houslos } \\
\text { Types }\end{array}$} & \\
\hline & ont & Rernt & $\begin{array}{l}\text { Both } \\
\text { Tenares }\end{array}$ & Oms & Rent & $\begin{array}{l}\text { Bath } \\
\text { Teaures }\end{array}$ & Om & Rent & $\begin{array}{l}\text { Both } \\
\text { Teutureas }\end{array}$ & Rent & $\begin{array}{l}\text { Eoth } \\
\text { Tenures }\end{array}$ & Om & Reat & \\
\hline $\begin{array}{l}\text { All LIJILAP, } \\
\text { Iligb-Jlordoo } \\
\text { Jloutebolds }\end{array}$ & 7.1 & 143 & 21.4 & 143 & 206 & $\$ 29$ & 7.1 & 143 & 21.4 & 143 & 143 & 28.6 & $n .4$ & 100 \\
\hline APDCReciplents & 125 & 125 & 2.0 & 125 & $\not \mathbf{D} .0$ & 375 & 0 & 25.0 & 8.0 & 125 & $12 s$ & $\mathbf{z . 0}$ & rso & 100 \\
\hline SSI Reciphente & 10.0 & $\mathbf{2 0 . 0}$ & $\mathbf{3 0 . 0}$ & 200 & 10.0 & 300 & jo.t. & 10.0 & $\mathbf{2 n . 0}$ & 20.0 & 200 & 40.0 & $\omega 0.0$ & 100 \\
\hline $\begin{array}{l}\text { lleating } \\
\text { Antistroce } \\
\text { Resipiests }\end{array}$ & 8.3 & 16.7 & 250 & 167 & 25.0 & 41.7 & 8.3 & 16.7 & 25.0 & 83 & בa & 303 & $\boldsymbol{\infty} .7$ & 100 \\
\hline $\begin{array}{l}\text { lood Stamp } \\
\text { Recipleotis }\end{array}$ & 83. & 16.7 & $\mathbf{2 5 . 0}$ & 83 & 25,0 & 303 & 83 & 167 & 25,0 & 167 & 167 & 25.0 & $\boldsymbol{\tau} .0$ & 100 \\
\hline $\begin{array}{l}\text { Unempicyment } \\
\text { Compengatod }\end{array}$ & 0 & 0 & 0 & 303 & 0 & 30 & נסנ & 0 & 333 & 30 & 303 & 68.7 & 313 & 100 \\
\hline $\begin{array}{l}\text { Subotdibod } \\
\text { fflowiog }\end{array}$ & 0 & 14,3 & 143 & 0 & 29 & 129 & 0 & 206 & 226 & 143 & 143 & 0 & 1000 & 100 \\
\hline
\end{tabular}




\section{APPENDIX A}

\section{TABLE C-17}

\section{ALL LIHEAP-ELIGIBLE, HIGH-BLRDEN HOUSEHOLDS BY PROGRAM PARTICIPATION NATIONAL}

\section{MEAN RESIDENTIAL ENERGY EXPENDITURES IN CURRENT DOLARS}

\begin{tabular}{|c|c|c|c|c|c|c|c|c|c|c|c|c|c|c|}
\hline & \multicolumn{13}{|c|}{ Houslas Type and Teanre } & \multirow[b]{3}{*}{$\begin{array}{l}\text { Alf } \\
\text { Hoase- } \\
\text { Ilolds }\end{array}$} \\
\hline & \multicolumn{3}{|c|}{ Mobile lloone } & \multicolumn{3}{|c|}{ Stoperamily } & \multicolumn{3}{|c|}{ Sonall Multitumily } & \multicolumn{2}{|c|}{ Lav Moltifamily } & \multicolumn{2}{|c|}{$\begin{array}{l}\text { All Itousing } \\
\text { Types }\end{array}$} & \\
\hline & Oma & Rent & $\begin{array}{l}\text { Both } \\
\text { Tenpures }\end{array}$ & Om & Rent & $\begin{array}{l}\text { Foth } \\
\text { Tennises }\end{array}$ & Oms & Rent & $\begin{array}{l}\text { Both } \\
\text { Teutres }\end{array}$ & R=أR= & $\begin{array}{l}\text { Both } \\
\text { Tenthes }\end{array}$ & Ond & Reat & \\
\hline A'DCRecipienls & $1,2,2$ & 1,122 & 1,160 & 1,374 & 1,361 & 1,36 & 0 & 1,648 & 1,048 & an & $\mathrm{Bn}$ & 1,324 & 1,10 & 1,137 \\
\hline SSI Rexipieats & $t, 104$ & 1,695 & 1,329 & 1,285 & 1,048 & 1,206 & $\$ \$ 3$ & 1,132 & I.im & 104 & 84 & $1,2,1$ & 1,045 & 1,123 \\
\hline $\begin{array}{l}\text { 1)tetint: } \\
\text { Astiatnoce } \\
\text { Rectpiloats }\end{array}$ & 1,277 & 3,013 & $1,15 ?$ & 1,153 & 1,319 & 1,19 & 2,40 & 1.110 & $1,2 \mathrm{~m}$ & 601 & 801 & $1,7 \mathbf{2 9}$ & 1,092 & $1,1+8$ \\
\hline $\begin{array}{l}\text { Rood SHapp } \\
\text { Recipisitts }\end{array}$ & 1,146 & 1,173 & 1,160 & 1,216 & 1,187 & 1,199 & 553 & 97 & 91 & 875 & 875 & 1,191 & $1,0 \leq 0$ & $t, 080$ \\
\hline $\begin{array}{l}\text { Unconptoymenit } \\
\text { Compenstion }\end{array}$ & 0 & 0 & 0 & $t, \mathbf{2 5 2}$ & 0 & 1,251 & 2,67 & 0 & 2,437 & 931 & 91 & 1,612 & 931 & 1,408 \\
\hline $\begin{array}{l}\text { Subsidirsed } \\
\text { llouging }\end{array}$ & 0 & 1006 & 1,086 & 0 & $1,1 \pm 5$ & 5,135 & 0 & 1,19: & 1,194 & $1,09 t$ & 1,081 & 0 & 1,130 & $1,1,7$ \\
\hline
\end{tabular}




\section{APPENDIX A}

\section{TABLE C-18}

\section{ALL LIHEAP-ELIGIBLE, HIGH-BURDEN HOUSEHOLDS BX PROGRAM PARTICIPATION NATIONAL}

\section{MEAN ENERTY BURDEN - EXPENDITURES AS \% OF INCOME}

\begin{tabular}{|c|c|c|c|c|c|c|c|c|c|c|c|c|c|c|}
\hline & \multicolumn{13}{|c|}{ Houslus Type and Teaure } & \multirow[b]{3}{*}{$\begin{array}{l}\text { All } \\
\text { flonso } \\
\text { Botids }\end{array}$} \\
\hline & \multicolumn{3}{|c|}{ Mobile Howe } & \multicolumn{3}{|c|}{ Stintze Pamily } & \multicolumn{3}{|c|}{ Smnll Mutifnmily } & \multicolumn{2}{|c|}{ Lage MuldJamlly } & \multicolumn{2}{|c|}{$\begin{array}{l}\text { Alt Housting } \\
\text { Types }\end{array}$} & \\
\hline & Oma & Rent & $\begin{array}{l}\text { Both } \\
\text { Tenures }\end{array}$ & Om. & Reat & $\begin{array}{l}\text { Botb } \\
\text { Tenures }\end{array}$ & Om & Rent & $\begin{array}{l}\text { Both } \\
\text { Tenares }\end{array}$ & Rent & $\begin{array}{l}\text { Both } \\
\text { Tentures }\end{array}$ & Onn & Rent & \\
\hline 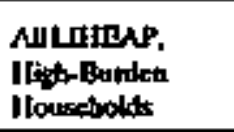 & 2 & 33 & $n$ & $n$ & 33 & $x$ & 28 & 37 & 35 & 31 & 31 & $n$ & $\mathbf{n}$ & 30 \\
\hline AFDCREeipieats & $\Rightarrow$ & $\mathbf{2 6}$ & 31 & $2 t$ & 40 & 37 & 0 & 37 & 37 & 28 & 2 & $\mathbf{3 l}$ & 35 & 3 \\
\hline SST RecipiedLs & 22 & $\mathbf{2 x}$ & 20 & 25 & 29 & 25 & $n$ & 26 & 27 & $\mathbf{z g}$ & 29 & 25 & $2 \mathrm{a}$ & 27 \\
\hline 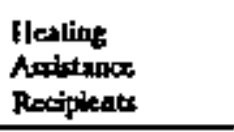 & 31 & $7 \mathbf{a}$ & 30 & $n$ & 37 & 32 & 26 & zs & 25 & $\mathbf{3}$ & 33 & 28 & m3 & 31 \\
\hline $\begin{array}{l}\text { Rood Sizmp } \\
\text { Recipienlts }\end{array}$ & 3 & $z$ & 31 & 30 & 36 & 3 & 37 & 36 & 36 & 33 & 33 & 31 & 35 & 34 \\
\hline 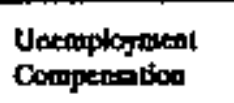 & 0 & 0 & 0 & 35 & 0 & 5 & $\mathbf{x}$ & 0 & 26 & 42 & 42 & 32 & 42 & 34 \\
\hline $\begin{array}{l}\text { Solbolituded } \\
\text { Ifouring }\end{array}$ & 0 & 31 & 31 & 0 & 37 & 37 & 0 & $\mathbf{3}$ & 34 & 36 & 36 & 0 & 35 & 35 \\
\hline
\end{tabular}




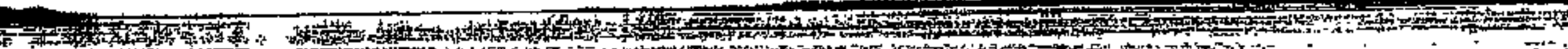

\section{APPENDIX A}

TABLE C-19

\section{ALL LIHEAP-ELIGIBLE, HIGH-BURDEN HOUSEHOLDS BY DEMOGRAPHIC CHARACTERISTICS NATTONAL}

THOUSANDS OF FOUSEHOLOS

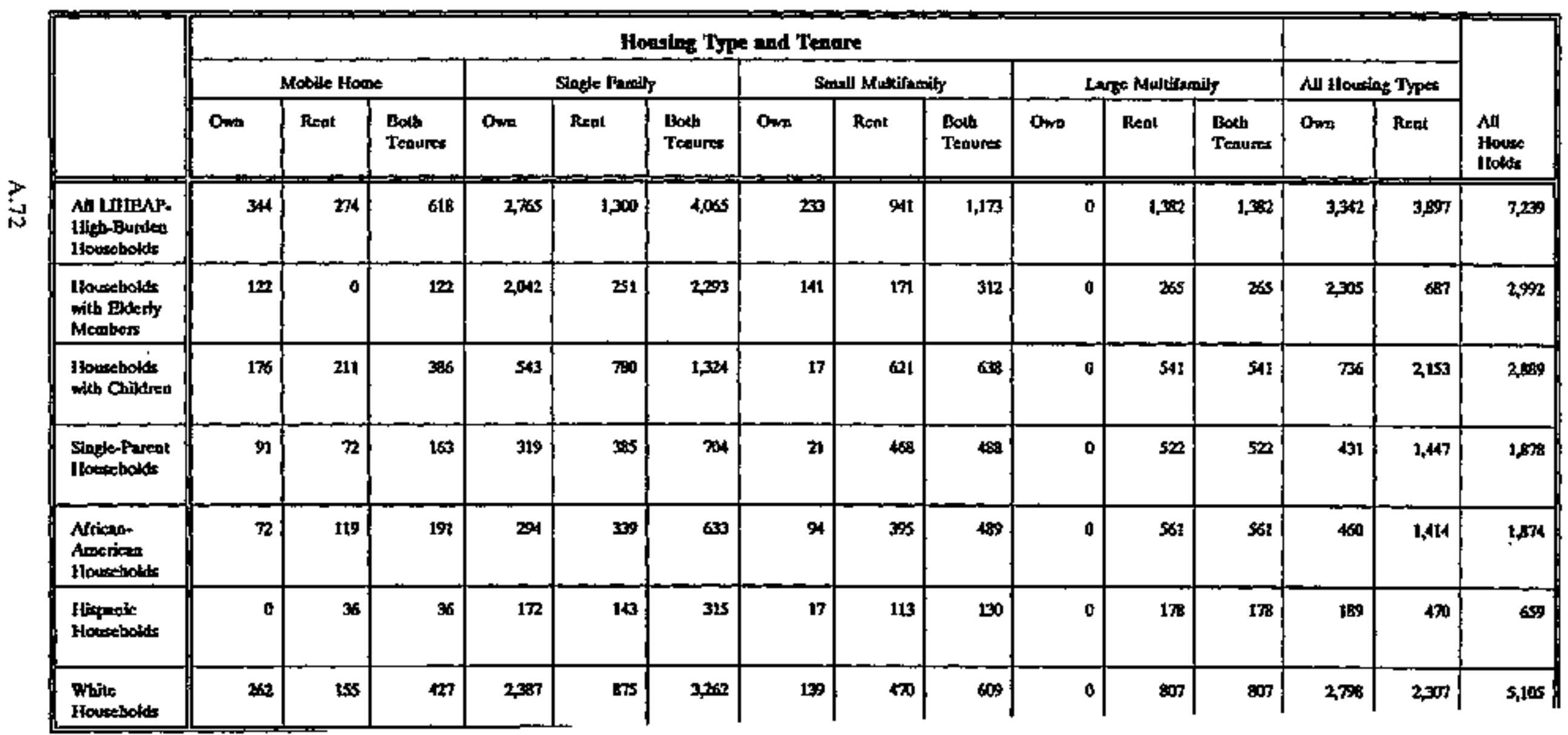




\section{APPENDIX A}

\section{TABLE C-20}

\section{ALI. LIHEAP-ELIGIBLE, HIGH-BURDEN HOUSEHOLDS BY DEMOGRAPHIC CHARACIERISTICS NATTONAL.}

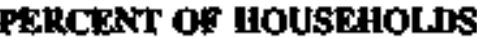

\begin{tabular}{|c|c|c|c|c|c|c|c|c|c|c|c|c|c|c|c|}
\hline & \multicolumn{12}{|c|}{ Honsing Type and Tenre } & & & \multirow[b]{3}{*}{$\begin{array}{l}\text { All } \\
\text { Houset } \\
\text { Jlolds }\end{array}$} \\
\hline & \multicolumn{3}{|c|}{ Noboik thome } & \multicolumn{3}{|c|}{ Stagke Pamily } & \multicolumn{3}{|c|}{ Sorall Multifnily } & \multicolumn{3}{|c|}{ Lox Multütamily } & \multicolumn{2}{|c|}{ All Housing Types } & \\
\hline & Oms & Reat & $\begin{array}{l}\text { Pout } \\
\text { Tenurex }\end{array}$ & Own & Reat & $\begin{array}{l}\text { Bath } \\
\text { Tenares }\end{array}$ & $\mathbf{O m}$ & Reat & $\begin{array}{l}\text { Bodh } \\
\text { Teanfes }\end{array}$ & Ond & Pteat & $\begin{array}{l}\text { Bodh } \\
\text { Terotres }\end{array}$ & Omn & Reat & \\
\hline 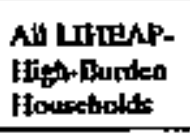 & 7.1 & 143 & 214 & 143 & 28.6 & 129 & 7.1 & 143 & 254 & 0.0 & 143 & 34.3 & 28.6 & 734 & 100.0 \\
\hline $\begin{array}{l}\text { [Jouscetoldk } \\
\text { With Eiderty } \\
\text { Membejs }\end{array}$ & 200 & 0.0 & 10.0 & 200 & 300 & 560 & 100 & 10.0 & 20.0 & 0.0 & 20.0 & 20.0 & 40.0 & tono & 1000 \\
\hline $\begin{array}{l}\text { Ifoustholds } \\
\text { wilt Childred }\end{array}$ & 83 & $\$ 3$ & 16.7 & 16.7 & 303 & 50.0 & 83 & 16.7 & 25.0 & 0.0 & 83 & 83 & 333 & 66.7 & 100,0 \\
\hline $\begin{array}{l}\text { Singte-Pareol } \\
\text { Houstholds }\end{array}$ & 9.t & 91 & 180 & 19.2 & $n a$ & ss & 9.1 & 182 & 273 & 0.0 & $9 . t$ & 9.1 & 364 & 69.6 & 100,0 \\
\hline 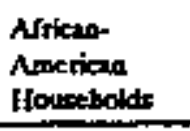 & R.S & $\mathbf{B 3}$ & 167 & 16.7 & 25.0 & 41.7 & 23 & 167 & 25.0 & 0.0 & 16.7 & 16.7 & 333 & 66.7 & 100.0 \\
\hline 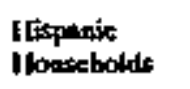 & 0.0 & 125 & كבו & $\not .0$ & 25,0 & $\operatorname{sos} 0$ & 125 & 125 & 20.0 & 0.0 & 125 & 125 & 375 & 0,5 & סמ \\
\hline $\begin{array}{l}\text { Whits } \\
\text { Ilouseboldt }\end{array}$ & as & 16.7 & 250 & 16.7 & 33.3 & 50,0 & $\mathrm{a}$ & a & 16.7 & 0.0 & 8.3 & 6.3 & 5,3 & 66.7 & 2000 \\
\hline
\end{tabular}




\section{APPENDIX A}

\section{TABLE C-21}

\section{ALL LIHEAP-ELIGBLE, HIGH-BURDEN HOUSEHOLDS BY DEMOGRAPHC CHARACTERISTICS NATIONAL}

\section{MOAN RESIDENTHL ENERGY EXRENDTURES TN CURRONT DOLLARS}

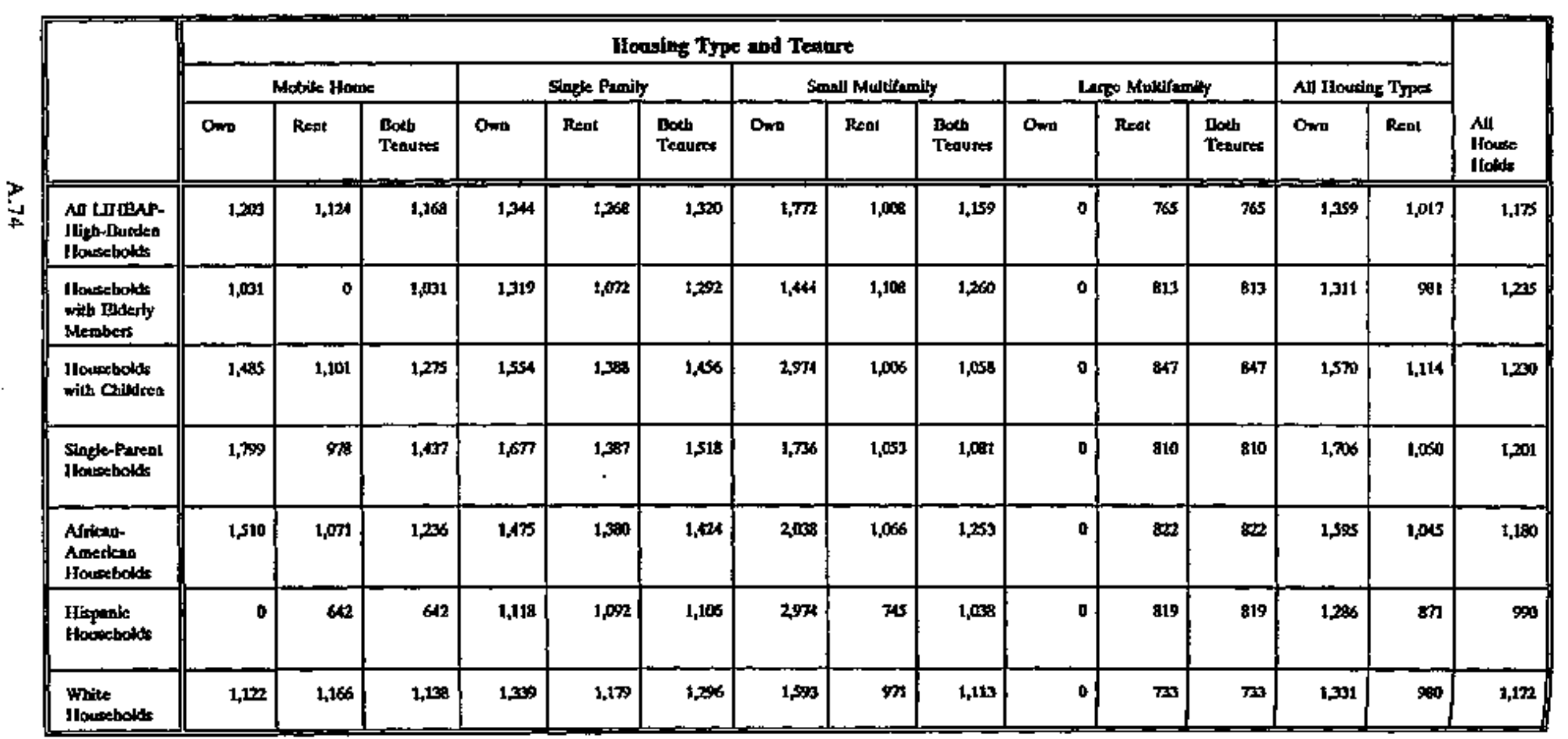


APPENDIX A

TABLE C-22

ALL LRHEAP-ELIGIBIE, HIGH-BURDEN HOUSEHOLDS BY DEMOGRAPHIC CHARACTERISTICS NATIONAL

MRAN ENERGY BURDEN - EXPENDITURES AS \% OF INCOME

\begin{tabular}{|c|c|c|c|c|c|c|c|c|c|c|c|c|c|c|c|}
\hline & \multicolumn{12}{|c|}{ Hoasing Type and Tenare } & & & \multirow[b]{3}{*}{$\begin{array}{l}\text { All } \\
\text { Ilouses } \\
\text { Ilotst }\end{array}$} \\
\hline & \multicolumn{3}{|c|}{ Motite Louse } & \multicolumn{3}{|c|}{ Singke Pamily } & \multicolumn{3}{|c|}{ Soall Nultitamity } & \multicolumn{3}{|c|}{ 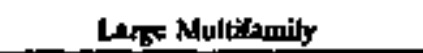 } & \multicolumn{2}{|c|}{ An licousing Typa } & \\
\hline & Ows & Rest & $\begin{array}{l}\text { Botk } \\
\text { Ttaur=s }\end{array}$ & Onn & Repit & $\begin{array}{l}\text { Both } \\
\text { Teopsas }\end{array}$ & Ow & Renal & $\begin{array}{l}\text { Botb } \\
\text { Tenures }\end{array}$ & Onv & Rrat & $\begin{array}{l}\text { Botb } \\
\text { Tenures }\end{array}$ & Onx & Reol & \\
\hline $\begin{array}{l}\text { Al LIRLAP. } \\
\text { 1ligh-Burdon } \\
\text { IJousebolds }\end{array}$ & $\mathbf{n}$ & $\mathbf{3 3}$ & $n$ & $\pi$ & 39 & 29 & 28 & 37 & $\mathbf{s}$ & 0 & 31 & $3 \mathbf{x}$ & 27 & $\mathbf{3}$ & 30 \\
\hline $\begin{array}{l}\text { Jlousobolds } \\
\text { witb Edetty } \\
\text { Members }\end{array}$ & 17 & 0 & t3 & 26 & 29 & 27 & 27 & 23 & $\mathbf{2 5}$ & - & 26 & 26 & 26 & $\mathbf{x}$ & 26 \\
\hline $\begin{array}{l}\text { llovecholds } \\
\text { with Chldren }\end{array}$ & $n$ & 30 & $\boldsymbol{z a}$ & $n$ & 3 & 3t & 22 & 11 & $4 i$ & 0 & 35 & 15 & $n$ & 36 & $\mathbf{3}$ \\
\hline 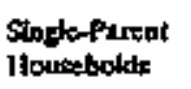 & 29 & 35 & 32 & 29 & 43 & 37 & $m$ & 37 & 37 & 0 & $\mathbf{3 2}$ & 32 & 20 & 37 & 35 \\
\hline $\begin{array}{l}\text { Arrkea- } \\
\text { Ameripan } \\
\text { Itousebolds }\end{array}$ & 16 & $\mathbf{3 5}$ & 28 & 5 & 3 & 36 & 34 & 43 & 41 & 0 & $\mathbf{x}$ & $\mathbf{2 6}$ & $\boldsymbol{s}$ & 35 & 33 \\
\hline 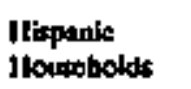 & 0 & $\mathbf{n}$ & 23 & 29 & $3 \mathbf{2}$ & $3 t$ & $\mathbf{2}$ & 12 & 39 & $\boldsymbol{0}$ & 42 & 42 & $\mathbf{z g}$ & 37 & $\mathbf{3}$ \\
\hline $\begin{array}{l}\text { White } \\
\text { Howsebolds }\end{array}$ & 24 & 31 & $z t$ & t7 & $\boldsymbol{x}$ & 28 & $x$ & 33 & 34 & 0 & 34 & $\mathbf{k}$ & 26 & $\mathbf{3}$ & 29 \\
\hline
\end{tabular}




\section{APPENDIX A}

\section{TABLE D-1}

\section{ALL ELIGIBLE, HIGH-EXPENDITURE, HIGH-BURDEN HOUSEHOLDS}

NATIONAL

\section{THOUSANDS OF HOUSEHOLDS}

\begin{tabular}{|c|c|c|c|c|c|c|c|c|c|c|c|c|c|c|c|}
\hline \multirow[b]{3}{*}{$\begin{array}{l}\text { Prinary } \\
\text { Heating } \\
\text { Ded }\end{array}$} & \multicolumn{12}{|c|}{ Housing Type and Teano } & & & \\
\hline & \multicolumn{3}{|c|}{ Motile Home } & \multicolumn{3}{|c|}{ Singe Rumily } & \multicolumn{3}{|c|}{ Sarall Mothifamily } & \multicolumn{3}{|c|}{ Lrece Multeirsmily } & \multicolumn{2}{|c|}{ All Ioosing Types } & \multirow[b]{2}{*}{$\begin{array}{l}\text { All } \\
\text { Hours } \\
\text { Holks }\end{array}$} \\
\hline & Om & Rent & $\begin{array}{l}\text { Both } \\
\text { Tesutes }\end{array}$ & Owo & Reat & $\begin{array}{l}\text { Both } \\
\text { Tenorse }\end{array}$ & Omb & Real & $\begin{array}{l}\text { Both } \\
\text { Tetures }\end{array}$ & Own & Fent & $\begin{array}{l}\text { Bolt } \\
\text { Tenutes }\end{array}$ & Own & Renl & \\
\hline Natural Gas & 64 & 45 & 109 & 200 & 203 & 404 & 106 & 127 & 20 & 0 & 10 & 100 & $3 n$ & 478 & 849 \\
\hline Deectricily & B & 0 & 8 & 14 & ans & 347 & 10 & 100 & 110 & $\mathbf{0}$ & $\boldsymbol{n}$ & $n$ & 162 & 35 & 537 \\
\hline Paed Ot & 0 & 9 & 9 & 118 & s & 126 & to & 56 & 65 & 0 & $\pi$ & $-\pi$ & 123 & 149 & $2 \pi$ \\
\hline Kerotepe & $\mathbf{z}$ & 19 & $\$ 1$ & a & 35 & as & 0 & 0 & a & 0 & 0 & 0 & 23 & 53 & 76 \\
\hline Propere & 1002 & $\pi$ & 173 & $1 \%$ & 0 & 179 & 0 & $\mathbf{0}$ & $\mathbf{0}$ & 0 & 0 & 0 & 282 & 71 & 352 \\
\hline Oiber Fuets & 31 & 0 & 31 & - & 0 & 0 & 0 & 0 & a & $\mathbf{0}$ & 0 & 0 & 31 & 0 & 31 \\
\hline \multicolumn{16}{|l|}{$\begin{array}{l}\text { No ticatiog } \\
\text { Poel Uted }\end{array}$} \\
\hline Al & 20 & 143 & $\mathbf{3 7}$ & 611 & 200 & 1,001 & 10 & 263 & +09 & 0 & 251 & $\mathbf{2 5 1}$ & $9 \%$ & 1,127 & 2,12 \\
\hline
\end{tabular}




\section{APPENDIX A}

\section{TABLE D-2}

\section{ALl ELIGIBLE, HIGH-EXPENDFTURE, HIGH-BURDEN HOUSEHOLDS} NATIONAL

\section{PERCXNT.OF HOUSEHOLDS}

\begin{tabular}{|c|c|c|c|c|c|c|c|c|c|c|c|c|c|c|c|}
\hline \multirow[b]{3}{*}{$\begin{array}{l}\text { Primery } \\
\text { Hestins: } \\
\text { Pnel }\end{array}$} & \multicolumn{12}{|c|}{ Hoosing Type and Tenure } & & & \multirow[b]{3}{*}{$\begin{array}{l}\text { All } \\
\text { jlowes } \\
\text { Ifolds }\end{array}$} \\
\hline & \multicolumn{3}{|c|}{ Mobite Home } & \multicolumn{3}{|c|}{ Singk Pamily } & \multicolumn{3}{|c|}{ Sonall Multifinmily } & \multicolumn{3}{|c|}{ Large Multihamity } & \multicolumn{2}{|c|}{ An Housing Typs } & \\
\hline & Ond & Rent & $\begin{array}{l}\text { Both } \\
\text { Teatise }\end{array}$ & Oma & Reat & $\begin{array}{l}\text { Boch } \\
\text { Teanse }\end{array}$ & On & Rea & $\begin{array}{l}\text { Bock } \\
\text { Teaures: }\end{array}$ & Ono & Reat . & $\begin{array}{l}\text { Both } \\
\text { Teaurs }\end{array}$ & owe & Read & \\
\hline Nater Gas & 3.0 & 21 & 5.1 & 9.4 & 9.6 & 19.0 & s.o & 60 & 11.0 & 0.0 & 4.9 & 4.9 & 175 & 20.5 & 40.0 \\
\hline Electridty & 0.4 & n.0.0 & 0,4 & 6.8 & 96 & 163 & 05 & 4.7 & 52 & 0.0 & $3 A$ & $3 x$ & 7.6 & 17,3 & 253 \\
\hline Sheel oil & 0,0 & 0.4 & D.4 & ss & 0.4 & 5.9 & os & 26 & 3.1 & 0.0 & 3.6 & 3.6 & 6.0 & 7.0 & 13.0 \\
\hline Keroectie & $\$$ & 0.9 & 20 & 0.0 & 16 & 1.6 & 0.0 & 0.0 & 0.0 & 0.0 & 0.0 & 0.0 & l.t. & 25 & 3.6 \\
\hline Propesse & 18 & 39 & $\$ 2$ & B.A & 0.0 & at & 0.0 & 0.0 & 0.0 & 0.0 & 0.0 & 0.0 & 133 & 13 & 16.6 \\
\hline Other Puets & is & 0.0 & 15 & 0.0 & 0.0 & 0.0 & $a 0$ & 0.0 & 0.0 & 0.0 & a.o & o. & is & a.0 & 15 \\
\hline \multicolumn{16}{|l|}{$\begin{array}{l}\text { No Ikeling } \\
\text { Pwel Uned }\end{array}$} \\
\hline All & 10.8 & 6.7 & 17s & 302 & 212 & 514 & 5.9 & 133 & 193 & 0.0 & 118 & $11 \mathrm{~B}$ & 46.9 & $5,3,1$ & 100.0 \\
\hline
\end{tabular}


APPENDIX A

TABLE D-3

ALL ELIGIBLE, HIGH-EXPENDITURE, HIGH-BURDEN HOUSEHOLDS REGIONAL / NORTHEAST

THLUSANDS OF househoLDS

\begin{tabular}{|c|c|c|c|c|c|c|c|c|c|c|c|c|c|c|c|}
\hline \multirow[b]{3}{*}{$\begin{array}{l}\text { Pritenty } \\
\text { Ilecting } \\
\text { Poed }\end{array}$} & \multicolumn{12}{|c|}{ Housing Type and Tenure } & & & \multirow[b]{3}{*}{$\begin{array}{l}\text { All } \\
\text { Ilowese } \\
\text { Ilodst }\end{array}$} \\
\hline & \multicolumn{3}{|c|}{ Mabila Howe } & \multicolumn{3}{|c|}{ Slmose Pamily } & \multicolumn{3}{|c|}{ Smali Multirismilly } & \multicolumn{3}{|c|}{ 1Arge Multifueaily } & \multicolumn{2}{|c|}{ All Houring Types } & \\
\hline & Omo & Rent & $\begin{array}{l}\text { Bols } \\
\text { Tanures }\end{array}$ & 0 & Rest & $\begin{array}{l}\text { Botb } \\
\text { Teanises }\end{array}$ & ond & Reol & $\begin{array}{l}\text { Both } \\
\text { Tenures }\end{array}$ & ONo & Revt & $\begin{array}{l}\text { Both } \\
\text { Tentres }\end{array}$ & $0_{m o}$ & Rent & \\
\hline Nitural Gas & 0 & 17 & 17 & 10 & 0 & 10 & 30 & $\$$ & $\mathbf{3}$ & D & $\mathbf{s}$ & $\mathbf{3}$ & 40 & 60 & $\tan$ \\
\hline Eluctridy & 0 & 0 & 0 & $\mathbf{0}$ & $\mathbf{v}$ & is & 0 & 13 & $\mathbf{3}$ & c & $\mathbf{5}$ & 15 & 0 & 42 & 12 \\
\hline Joet on & 0 & 9 & 9 & 23 & 0 & $\mathbf{2}$ & 10 & 40 & so & 0 & $\pi$ & $\pi$ & $\mathbf{0}$ & 126 & 158 \\
\hline Xersedoe & 23 & 0 & $\mathbf{n}$ & 0 & 0 & 0 & 0 & o & a & 0 & o & 0 & 2 & 0 & $\mathbf{2}$ \\
\hline Peopane & & & & & . & & & & & & & & & & \\
\hline Other Pucls & & & & & & & & & & & & & & & \\
\hline 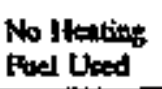 & & & & & & & & & & & & & & & \\
\hline All & 23 & $\mathbf{2 5}$ & 48 & 30 & $\mathbf{t s}$ & 47 & 3 & 62 & $10 t$ & 0 & 126 & $12 x$ & \$s & 228 & $m$ \\
\hline
\end{tabular}




\section{APPENDIX A}

\section{TABLE D-4}

ALL ELIGIBLE, HIGH-EXPENDITURE, HIGH-BURDEN HOUSEHOLDS REGIONAL / NORTHEAST

PERCENT OF HOUSEHOLDS

\begin{tabular}{|c|c|c|c|c|c|c|c|c|c|c|c|c|c|c|c|}
\hline \multirow[b]{3}{*}{$\begin{array}{l}\text { Primniry } \\
\text { lieating } \\
\text { Poel }\end{array}$} & \multicolumn{12}{|c|}{ Boasing Type and Teaure } & & & \multirow[b]{3}{*}{$\begin{array}{l}\text { All } \\
\text { Houss } \\
\text { Hothr }\end{array}$} \\
\hline & \multicolumn{3}{|c|}{ Mohile Hown } & \multicolumn{3}{|c|}{ Single Phoilty } & \multicolumn{3}{|c|}{ Smalt Mutufamily } & \multicolumn{3}{|c|}{ LG Mutiramíly } & \multicolumn{2}{|c|}{ Att Ikwsing Types } & \\
\hline & Owe & Real & $\begin{array}{l}\text { Both } \\
\text { Tenowes }\end{array}$ & Om & Rent & $\begin{array}{l}\text { Bedh } \\
\text { Tenurar }\end{array}$ & 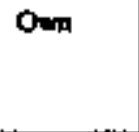 & Rent & $\begin{array}{l}\text { Elotb } \\
\text { Tequre }\end{array}$ & Don & Rent & $\begin{array}{l}\text { Bolh } \\
\text { Teaurs }\end{array}$ & Onx & Reat & \\
\hline Natural Gen & 00 & 5.1 & s.t & 3.1 & 0.0 & 11 & 92 & 27 & 11.9 & 00 & $10 B$ & 108 & 122 & 186 & 30.8 \\
\hline Dectrikity & 0.0 & 0.0 & 0.0 & 0.0 & 15 & 45 & 0.0 & 4.0 & 4.0 & 0.0 & 4.8 & 4.6 & 0.0 & 13.1 & 23.1 \\
\hline Pucl on & 0.0 & 28 & 28 & 7.1 & 0.0 & 7.1 & 3.0 & t2.4 & $\mathbf{t 5 . 4}$ & 0.0 & 23.7 & 2.7 & $10 . \mathbf{t}$ & 389 & 490 \\
\hline Kerocene & $\mathbf{7 . 1}$ & oo & 7,1 & 0.0 & 00 & 0.0 & 0.0 & 0.0 & 0.0 & 0.0 & 0.0 & 0.0 & 3,1 & 0,0 & 7.1 \\
\hline \multicolumn{16}{|l|}{ Propude } \\
\hline \multicolumn{16}{|l|}{ Ouher thets } \\
\hline \multicolumn{16}{|l|}{$\begin{array}{l}\text { No lieating; } \\
\text { Fuel Uneed }\end{array}$} \\
\hline All & $\pi .1$ & 39 & 15.0 & 102 & 45 & 14.7 & $\mathbf{1 2 . 1}$ & 19.1 & $3 t_{3}$ & 0.0 & 39.1 & $\$, 1$ & 20.4 & 7.5 & $\operatorname{mos}$ \\
\hline
\end{tabular}




\section{APPENDIX A}

TABLE D-5

ALL ELIGIRLE, HIGH-EXPENDITURE, HIGH-BURDEN HOUSEHOLDS REGIONAL / MIDWEST

\section{THOUSANDS OF HOUSEHOLDS}

\begin{tabular}{|c|c|c|c|c|c|c|c|c|c|c|c|c|c|c|c|}
\hline \multirow[b]{3}{*}{$\begin{array}{l}\text { Primasty } \\
\text { Heating } \\
\text { Foed }\end{array}$} & \multicolumn{12}{|c|}{ Housine Type nnd Tenire } & & & \multirow[b]{3}{*}{$\begin{array}{l}\text { All } \\
\text { House } \\
\text { llows }\end{array}$} \\
\hline & \multicolumn{3}{|c|}{ Mobtle Howe } & \multicolumn{3}{|c|}{ Sindo Femily } & \multicolumn{3}{|c|}{ Sanall Multtamily } & \multicolumn{3}{|c|}{ Lase Multifamily } & \multicolumn{2}{|c|}{ Al Housing $T_{y p e x}$} & \\
\hline & Oms & Rept & $\begin{array}{l}\text { Bodh } \\
\text { Teaures }\end{array}$ & Om & Frat & $\begin{array}{l}\text { Doth } \\
\text { Teaurs }\end{array}$ & $a_{\text {nnt }}$ & Pent & $\begin{array}{l}\text { Bolk } \\
\text { Teadres }\end{array}$ & Oms & Fent & $\begin{array}{l}\text { Bokb } \\
\text { Terutes }\end{array}$ & Own & Rent & \\
\hline Natural Ges & a & 1t & 11 & ss & $\pi$ & 132 & 54 & 87 & 142 & 0 & 17 & 17 & 108 & gn & 301 \\
\hline Dicaricity & B & 0 & 8 & 34 & 0 & 34 & 0 & 0 & 0 & 0 & 0 & 0 & 43 & 0 & 43 \\
\hline Pueft on & 0 & 0 & 0 & $\mathrm{sg}$ & $\mathbf{g}$ & 66 & 0 & to & 16 & 0 & 0 & 0 & $s q$ & 24 & 82 \\
\hline \multicolumn{16}{|l|}{ Kemenes } \\
\hline Propase & 19 & 35 & ss & 118 & 0 & 118 & 0 & 0 & 0 & 0 & 0 & 0 & $\mathbf{m}$ & $\mathbf{s}$ & 172 \\
\hline Ouluer l'uels & 31 & 0 & $3 \mathbf{l}$ & 0 & 0 & 0 & 0 & 0 & o & 0 & 0 & 0 & 31 & o & 31 \\
\hline \multicolumn{16}{|l|}{$\begin{array}{l}\text { No ItenAins } \\
\text { Puel Uned }\end{array}$} \\
\hline $\begin{array}{l}\text { All } \\
\text { Eloustrolds }\end{array}$ & 59 & 46 & Jos & $\mathbf{2 5 H}$ & 85 & $\boldsymbol{3 9}$ & $\mathbf{s}$ & 103 & 157 & 0 & 17 & 17 & $3 n$ & 251 & 629 \\
\hline
\end{tabular}




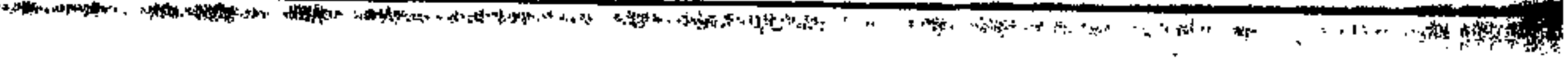

APPENDIX A

TABLE D-6

ALL ELIGIBLE, HIGH-EXPENDITURE, HIGH-BURDEN HOUSEHOLDS REGIONAL / MIDWEST

PERCENT OF HOUSEHOL.DS

\begin{tabular}{|c|c|c|c|c|c|c|c|c|c|c|c|c|c|c|c|}
\hline \multirow[b]{3}{*}{$\begin{array}{l}\text { Primary } \\
\text { Heating } \\
\text { Foed }\end{array}$} & \multicolumn{12}{|c|}{ Hoosine Type and Teapre } & & & \multirow[b]{3}{*}{$\begin{array}{l}\text { All } \\
\text { Iloust } \\
\text { Ilotets }\end{array}$} \\
\hline & \multicolumn{3}{|c|}{ Nobile Hoone } & \multicolumn{3}{|c|}{ Siode Penily } & \multicolumn{3}{|c|}{ Somedt Mutifinally } & \multicolumn{3}{|c|}{ Late Multhanlly } & \multicolumn{2}{|c|}{ All Iloxsing Types } & \\
\hline & Own & Real & $\begin{array}{l}\text { Beat } \\
\text { Temares }\end{array}$ & Omn & Real & $\begin{array}{l}\text { Bolb } \\
\text { Tcourse }\end{array}$ & Onis & Rent & $\begin{array}{l}\text { Both } \\
\text { Tenwers }\end{array}$ & Owo & Rebt & $\begin{array}{l}\text { Doxh } \\
\text { Tenvers }\end{array}$ & Own & Rent & \\
\hline Naturn Ges & 0.0 & 1.7 & 1.7 & B.7 & 122 & 21.0 & 8.7 & 13.9 & 25 & 0.0 & 27 & 27 & 17.4 & 30.5 & 179 \\
\hline Dectricty & 13 & $\alpha, 0$ & 11 & ss & 0.0 & 35 & 0.0 & 00 & 0.0 & on & 0.0 & 0.0 & 68 & 0.0 & 68 \\
\hline Fuel Oil & 0.0 & $\mathbf{0 . 0}$ & B.:O & 9.2 & 13 & 105 & 0.0 & 2 & 25 & 0.0 & 0.0 & 0.0 & 92 & 3.8 & 130 \\
\hline \multicolumn{16}{|l|}{ Kerosedo } \\
\hline Propane & 3.0 & 56 & 87 & 18T & 0.0 & 18.7 & 0.0 & 0.0 & 0.0 & 00 & 0.0 & 0.0 & 21.7 & 5.6 & 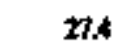 \\
\hline Othet Puels & 49 & 0.0 & 19 & $\mathbf{0 . 0}$ & 0.0 & 0.0 & 0.0 & 0.0 & 0.0 & $\mathbf{0 0}$ & 0.0 & 0.0 & 4.9 & 0.0 & 49 \\
\hline \multicolumn{16}{|l|}{$\begin{array}{l}\text { No lleatings } \\
\text { Puel Uned }\end{array}$} \\
\hline $\begin{array}{l}\text { All } \\
\text { Hotwebolds }\end{array}$ & 93 & 74 & 167 & 121 & 135 & 55.6 & 27 & 16.4 & 20 & 0.0 & 27 & 27 & 60.0 & 40.0 & 1000 \\
\hline
\end{tabular}


APPENDIX A

TABLE D-7

ALL ELJGIBLE, HIGH-EXPENDITURE, HIGH-BURDEN HOUSEHOLDS REGIONAL / SOUTH

THOUSANDS OF housemiolos

\begin{tabular}{|c|c|c|c|c|c|c|c|c|c|c|c|c|c|c|c|}
\hline \multirow[b]{3}{*}{$\begin{array}{l}\text { Prinury } \\
\text { fleating } \\
\text { Fod }\end{array}$} & \multicolumn{12}{|c|}{ Housin: Type and Teare } & & & \multirow[b]{3}{*}{$\begin{array}{l}\text { All } \\
\text { Eloust } \\
\text { Ilotsts }\end{array}$} \\
\hline & \multicolumn{3}{|c|}{ Mobile Howe } & \multicolumn{3}{|c|}{ Single Pumily } & \multicolumn{3}{|c|}{ Srasill Multśnemity } & \multicolumn{3}{|c|}{ targ Multilumily } & \multicolumn{2}{|c|}{ All tousing 'Types } & \\
\hline & Ond & Reat & $\begin{array}{l}\text { Bour } \\
\text { Tenore: }\end{array}$ & Omp & Hent & $\begin{array}{l}\text { Booth } \\
\text { Tepores }\end{array}$ & Ono & R=nl & $\begin{array}{l}\text { Boebh } \\
\text { Tesurs }\end{array}$ & Om & Reat & $\begin{array}{l}\text { Bolb } \\
\text { Teaures }\end{array}$ & $0 \times 0$ & Renl & \\
\hline Natural Gess & 2 & 0 & $\mathbf{n}$ & 75 & $\mathbf{3 2}$ & 107 & $\boldsymbol{n}$ & 2t & 43 & 0 & $\mathbf{n}$ & $\mathbf{2 0}$ & 200 & $n$ & 192 \\
\hline Bectritcily & 0 & 0 & $\mathbf{0}$ & 80 & 62 & 142 & 0 & 42 & 42 & 0 & 0 & 0 & 80 & 104 & 184 \\
\hline Pued oil & 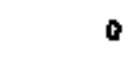 & 0 & 0 & 37 & 0 & 37 & o & 0 & 0 & 0 & o & $\mathbf{0}$ & $\$$ & $\mathbf{0}$ & 77 \\
\hline Nerouran & 0 & 19 & 19 & 0 & 35 & 35 & n & 0 & $\mathbf{0}$ & 0 & 0 & 0 & a & 50 & so \\
\hline Propene & s1 & $u$ & 36 & 61 & $\cdot 0$ & 61 & 0 & 0 & 0 & 0 & 0 & 0 & tts & $2 *$ & 137 \\
\hline \multicolumn{16}{|l|}{ Ober Puek } \\
\hline \multicolumn{16}{|l|}{$\begin{array}{l}\text { No fkatios: } \\
\text { Pual Uima }\end{array}$} \\
\hline $\begin{array}{l}\text { All } \\
\text { Houstebokt }\end{array}$ & $\mathbf{x}$ & 43 & 117 & $\mathbf{2 5 3}$ & 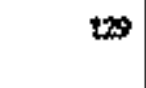 & 济 & $\boldsymbol{z}$ & 6 & 8 & 0 & 20 & to & 309 & 255 & 601 \\
\hline
\end{tabular}




\section{APPENDIX A}

\section{TABLE D-8}

\section{ALL ELIGIBL屯, HIGH-EXPENDITURE, HIGH-BURDEN HOUSEHOLDS REGIONAL / SOUTH}

PERCENT OF HOUSEITOLDS

\begin{tabular}{|c|c|c|c|c|c|c|c|c|c|c|c|c|c|c|c|}
\hline \multirow[b]{3}{*}{$\begin{array}{l}\text { Primiry } \\
\text { lfeatings } \\
\text { Foed }\end{array}$} & \multicolumn{12}{|c|}{ Honsing Type and Teoure } & & & \multirow[b]{3}{*}{$\begin{array}{l}\text { All } \\
\text { Ifouse } \\
\text { ILolds }\end{array}$} \\
\hline & \multicolumn{3}{|c|}{ Motile ifows } & \multicolumn{3}{|c|}{ Saeje Panily } & \multicolumn{3}{|c|}{ Sonall Multi'tantly } & \multicolumn{3}{|c|}{ Letog Multifamily } & \multicolumn{2}{|c|}{ All Jlowing Ths } & \\
\hline & Owo & Rent & $\begin{array}{l}\text { Both } \\
\text { Teaures }\end{array}$ & Omu & $R \in$ ad & $\begin{array}{l}\text { Both } \\
\text { Tentures }\end{array}$ & Owo & Reot & $\begin{array}{l}\text { Botb } \\
\text { Teaures }\end{array}$ & Ond & Fteot & $\begin{array}{l}\text { Bolb } \\
\text { Teaures }\end{array}$ & Omu & Rent & \\
\hline Natural $\mathrm{Oss}$ & 38 & 0.0 & 3.9 & 124 & 53 & 178 & t7 & 35 & 7.1 & $\infty 0$ & 33 & 33 & 19.8 & 120 & 31.9 \\
\hline Dectriaty & d.0. & 0.0 & 0.0 & 232 & 103 & 23.4 & 0.0 & 7.0 & 7.0 & 0.0 & 0.0 & 0.0 & 132 & 173 & 30.4 \\
\hline Tuel oil & 0.0 & 0.0 & 0.0 & 6.1 & 0.0 & 61 & 0.0 & 0.0 & 0.0 & 0.0 & 0,0 & 0.0 & 6.t & 0.0 & 6.1 \\
\hline Xemocose & 0.0 & $\mathbf{1 . 1}$ & 3.1 & 0.0 & 58 & 58 & 0.0 & 0.0 & 0.0 & 0.0 & 0.0 & 0.0 & 0.0 & 89 & 20 \\
\hline Propine & is & 40 & 126 & 1022 & 0.0 & 10.2 & 0.0 & 0.0 & $\mathbf{0 . 0}$ & 00 & 0.0 & 0.0 & 18.7 & 4.0 & 277 \\
\hline \multicolumn{16}{|l|}{ Otbee Puels } \\
\hline \multicolumn{16}{|l|}{$\begin{array}{l}\text { No Healin; } \\
\text { Pow Uexat }\end{array}$} \\
\hline $\begin{array}{l}\text { All } \\
\text { 1Jousebestase }\end{array}$ & 123 & 7.1 & 19.4 & 419 & 21.3 & at:2 & 37 & tos & 14.1 & 0.0 & 3.3 & $3 \mathbf{3}$ & S7: & 122 & 100.0 \\
\hline
\end{tabular}




\section{APPENDIX A}

\section{TABLE D-9}

ALC ELIGIBLE, HIGH-EXPENDITURE, HIGH-BURDEN HOUSEHOLDS REGIONAL / WEST

THOUSANDS OF HOUSEHOLDS

\begin{tabular}{|c|c|c|c|c|c|c|c|c|c|c|c|c|c|c|c|}
\hline \multirow[b]{3}{*}{$\begin{array}{l}\text { Prinung } \\
\text { thentiug } \\
\text { Foed }\end{array}$} & \multicolumn{12}{|c|}{ Hoasles The and Teavere } & & & \multirow[b]{3}{*}{$\begin{array}{l}\text { All } \\
\text { ltowse } \\
\text { Ifokes }\end{array}$} \\
\hline & \multicolumn{3}{|c|}{ Mobilt thoos } & \multicolumn{3}{|c|}{ Sinele Pandily } & \multicolumn{3}{|c|}{ Sonill Mudtraity } & \multicolumn{3}{|c|}{ Large Mulutifanolity } & \multicolumn{2}{|c|}{ All flowting Typos } & \\
\hline & Owd & Reat & $\begin{array}{l}\text { Botb } \\
\text { Teanses }\end{array}$ & Own & Rent & 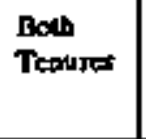 & Oma & Rent & $\begin{array}{l}\text { Boch } \\
\text { Teaurs }\end{array}$ & Own & Reat & $\begin{array}{l}\text { Both } \\
\text { Teauses }\end{array}$ & Own & Feat & \\
\hline Nalues Gas & 41 & IT & $\mathbf{5 8}$ & 61 & 9 & 155 & 0 & 10 & to & 0 & 32 & $n$ & 102 & 154 & 250 \\
\hline Electricily & 0 & 0 & $\mathbf{0}$ & 30 & $12 \pi$ & 557 & 16 & 45 & ss & o & S7 & 57 & 40 & 228 & 269 \\
\hline Puel $\mathbf{O}^{\dagger}$ & & & & & & & & & & & & & & & \\
\hline Kerwacke & & & & & . & & & & & & & & & & \\
\hline Propune & 32 & 11 & 43 & 0 & a & 0 & 0 & 0 & 0 & 0 & a & 0 & 3n & a & 43 \\
\hline Other Puets & & & & & & & & & & & & & & & \\
\hline $\begin{array}{l}\text { No Hlatiogs } \\
\text { Fuel Uned }\end{array}$ & & & & & & & & & & & & & & & \\
\hline All illetebotits & $\pi$ & 23 & 101 & 91 & 21 & 312 & 10 & $5 s$ & 65 & o & 69 & 8 & 174 & 393 & 567 \\
\hline
\end{tabular}




\section{APPENDIX A}

\section{TABLE D-10}

ALL ELIGLBL, HIGH-EXPENDITURE, HIGH-BURDEN HOUSEHOLDS

REGIONAL / WEST

\section{PERCENT OF HOUSEIIOLS}

\begin{tabular}{|c|c|c|c|c|c|c|c|c|c|c|c|c|c|c|c|}
\hline \multirow[b]{3}{*}{$\begin{array}{l}\text { Priming } \\
\text { Jeating } \\
\text { Pod }\end{array}$} & \multicolumn{12}{|c|}{ Howsing Type and Teoure } & & & \multirow[b]{3}{*}{$\begin{array}{l}\text { All } \\
\text { Ilouse } \\
\text { Iloulte }\end{array}$} \\
\hline & \multicolumn{3}{|c|}{ Mobile Itoose } & \multicolumn{3}{|c|}{ Single Family } & \multicolumn{3}{|c|}{ Sorelt Multilamily } & \multicolumn{3}{|c|}{ Lats Mutlinmily } & \multicolumn{2}{|c|}{ All tousing Types } & \\
\hline & Own & $R_{ \pm} \mathrm{dt}$ & $\begin{array}{l}\text { Both } \\
\text { Temites }\end{array}$ & סירים & Reot & $\begin{array}{l}\text { Bokb } \\
\text { Tanures }\end{array}$ & Ono & Rent & $\begin{array}{l}\text { Dokb } \\
\text { Teaures }\end{array}$ & Om & Rent & $\begin{array}{l}\text { Botb } \\
\text { Tenutes }\end{array}$ & ONo & Ront & \\
\hline Nolutal Oيt & 22 & 3.0 & 103 & 108 & 16.6 & 27.4 & 0.0 & 1.7 & t.t. & 0,0 & 5.7 & 5.7 & 18.0 & 27.1 & 4.t \\
\hline Dectrikty & 0.0 & ao & 0.0 & 52 & 24 & 27.6 & ts & 7.9 & 9.7 & 0.0 & 10.0 & 10.0 & 70 & 40.3 & 67,3 \\
\hline \multicolumn{16}{|l|}{ Pus oil } \\
\hline \multicolumn{16}{|l|}{ Kerosese } \\
\hline Propede & 5.6 & 20 & 76 & 0.0 & 0.0 & 0.0 & 0.0 & 00 & 00 & 0.0 & 0.0 & 0.0 & 5,6 & 20 & 76 \\
\hline \multicolumn{16}{|l|}{ Otber Pust: } \\
\hline \multicolumn{16}{|l|}{$\begin{array}{l}\text { Sto Ileating } \\
\text { Puel Uned }\end{array}$} \\
\hline All & 129 & 3.0 & 179 & 160 & 39.0 & 550 & 18 & 9.2 & $11 s$ & $\infty$ & 15.7 & 15.7 & 30.6 & 69.4 & 10000 \\
\hline
\end{tabular}

Source: 1990 Residenitas Ene rigy Consumpiton Samey 


\section{APPENDIX A}

\section{TABLE D-11}

\section{ALL ELIGIBLE, HIGH-EXPENDITURE, HIGH-BURDEN HOUSEHOLDS NATIONAL}

\section{MEAN RESLENTLL ENERGY EXPENDITURES IN CURRENT DOULARS}

\begin{tabular}{|c|c|c|c|c|c|c|c|c|c|c|c|c|c|c|c|}
\hline \multirow[b]{3}{*}{$\begin{array}{l}\text { Priming } \\
\text { Heating } \\
\text { Fofe }\end{array}$} & \multicolumn{12}{|c|}{ Honsing Type and Tenare } & & & \multirow[b]{3}{*}{$\begin{array}{l}\text { All } \\
\text { Ifoums } \\
\text { Ilokts }\end{array}$} \\
\hline & \multicolumn{3}{|c|}{ Mobike tfoox } & \multicolumn{3}{|c|}{ 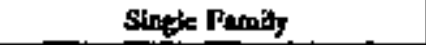 } & \multicolumn{3}{|c|}{ Stanl Multutamily } & \multicolumn{3}{|c|}{ Ierge Muttifamily } & \multicolumn{2}{|c|}{ AIt Ilouslag $7 \mathrm{yp}=$} & \\
\hline & Onn & Rept & $\begin{array}{l}\text { Bolit } \\
\text { Tepunst }\end{array}$ & Owu & Enat & $\begin{array}{l}\text { Both } \\
\text { Teoums }\end{array}$ & Omo & Repl & $\begin{array}{l}\text { Boith } \\
\text { Terores }\end{array}$ & Omo & Reat & $\begin{array}{l}\text { Bow } \\
\text { Tenurts }\end{array}$ & Own & Repl & \\
\hline Natural Ger & 543 & 1,299 & 81 & 1,451 & 1,515 & 1,498 & 1816 & 1,200 & 1,518 & 0 & $\mathbf{B 5 8}$ & $\$$ & 1,390 & 1,295 & 1,340 \\
\hline Ledricily & 1,879 & 0 & 1,878 & 1,260 & 5,023 & t,12: & 99 & 873 & 604 & 0 & 986 & 966 & $t, 275$ & 976 & 1,065 \\
\hline J'lel 에 & o & 2,044 & 2044 & $1,74 ?$ & 22040 & 1,700 & 1,89 & 1,375 & 2,466 & 0 & 1,244 & 1,244 & 1,755 & 1,396 & 1,566 \\
\hline Keroecdec & 1,20 & BTS & 1,128 & 0 & 2,450 & 2,410 & a & o & 0 & 0 & 0 & 0 & 1,333 & 1878 & 1, ns \\
\hline Propene & 1,468 & 1,463 & 1,460 & 1530 & $\cdot \mathbf{a}$ & $t, 50$ & a & 0 & 0 & 0 & $\mathbf{0}$ & 0 & $t_{0} \times 109$ & 1,463 & 1,500 \\
\hline Other Puet: & 1,297 & 0 & 1,237 & 0 & 0 & 0 & 0 & o & 0 & 0 & o & 0 & 1,25 & 0 & 1,237 \\
\hline $\begin{array}{l}\text { No lkating } \\
\text { Puel Uked }\end{array}$ & & & & & & & & & & & & & & & \\
\hline IIl & 1,180 & 1,369 & 1,253 & 1,485 & 1389 & 1,446 & 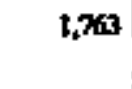 & 1,150 & 1,508 & 0 & t,, 004 & $1,0 \mathrm{OH}$ & 1,40 & 1,240 & 1,309 \\
\hline
\end{tabular}


APPENDIX A

TABLE D-12

ALL ELIGIBLE, HIGH-WXPENDFURE, HIGH-BURDEN HOUSEHOLDS NATTONAL

STANDARD DEVIATTON OF MEAN EXPENDS, IN CURRENT DOLLARS

\begin{tabular}{|c|c|c|c|c|c|c|c|c|c|c|c|c|c|c|c|}
\hline \multirow[b]{3}{*}{$\begin{array}{l}\text { Primary } \\
\text { llesting } \\
\text { Foes }\end{array}$} & \multicolumn{12}{|c|}{ Hoabint Type and Tenure } & & & \multirow[b]{3}{*}{$\begin{array}{l}\text { All } \\
\text { Howese } \\
\text { Hontet }\end{array}$} \\
\hline & \multicolumn{3}{|c|}{ Moble Home } & \multicolumn{3}{|c|}{ Sintede Panily } & \multicolumn{3}{|c|}{ Somall Multífxmity } & \multicolumn{3}{|c|}{ Lris Multifomity } & \multicolumn{2}{|c|}{ All Housing Typos } & \\
\hline & Om & Reol & $\begin{array}{l}\text { Both } \\
\text { Tropts }\end{array}$ & Ons & Reat & $\begin{array}{l}\text { Botb } \\
\text { Tenures }\end{array}$ & own & Real & $\begin{array}{l}\text { Both } \\
\text { Teosers }\end{array}$ & Oma & Rent & $\begin{array}{l}\text { Both } \\
\text { Tenores }\end{array}$ & Own & Ptal & \\
\hline Natural Chs & 204 & 300 & 43 & 606 & 49 & 59 & $6 \pi$ & $\mathbf{3 0 7}$ & $\pi B$ & 0 & 343 & 343 & 717 & 469 & 593 \\
\hline Doxtridy & 0 & 0 & 0 & 362 & 399 & 402 & 0 & $\mathbf{m}$ & 217 & 0 & 148 & 148 & 375 & 329 & $3 \pi$ \\
\hline Tuel OT & o & 0 & 0 & 172 & 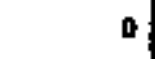 & 180 & 0 & 348 & 399 & 0 & 396 & $\mathbf{3 m}$ & 143 & 452 & m \\
\hline Kerusene & 58 & 0 & 22 & 0 & $m$ & m & 0 & 0 & 0 & 0 & 0 & o & $\mathbf{s} \mathbf{s}$ & 1,076 & 935 \\
\hline Propavo & 123 & 575 & 91 & 659 & o & 659 & 0 & o & 0 & 0 & 0 & 0 & 585 & 575 & 58 \\
\hline Otber Puets & o & 0 & 0 & 0 & .0 & 0 & 0 & 0 & 0 & 0 & 0 & 0 & 0 & 0 & o \\
\hline \multicolumn{16}{|l|}{$\begin{array}{l}\text { No lleuting } \\
\text { Puall Utods }\end{array}$} \\
\hline $\begin{array}{l}\text { All } \\
\text { Howntholds }\end{array}$ & 514 & 508 & 5at & $5+12$ & 699 & 506 & 606 & 35 & 552 & o & 360 & 363 & 57 & 531 & SG \\
\hline
\end{tabular}




\section{APPENDIX A}

\section{TABLE D-13}

\section{ALL ELIGIBLE, HIGH-EXPENDITURE, HIGH-BURDEN HOUSEHOLDS NATIONAL}

MEAN ENERGX BURDEN - EXPENDTIURES AS \% OF INCOME

\begin{tabular}{|c|c|c|c|c|c|c|c|c|c|c|c|c|c|c|c|}
\hline \multirow[b]{3}{*}{$\begin{array}{l}\text { Prinary } \\
\text { Fitenting } \\
\text { Poel }\end{array}$} & \multicolumn{12}{|c|}{ Hoasing Type end Tenere } & & & \multirow[b]{3}{*}{ 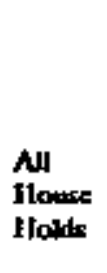 } \\
\hline & \multicolumn{3}{|c|}{ Mobile I lowe } & \multicolumn{3}{|c|}{ Slonglo Pamily } & \multicolumn{3}{|c|}{ Smath Mertramily } & \multicolumn{3}{|c|}{ Ltge Muturmmily } & \multicolumn{2}{|c|}{ All thouriag Types } & \\
\hline & ons & Feat & $\begin{array}{l}\text { Botb } \\
\text { Teporse }\end{array}$ & Ons & Real & $\begin{array}{l}\text { Both } \\
\text { Tanures }\end{array}$ & ONo & Reat & $\begin{array}{l}\text { Doob } \\
\text { Tewirs: }\end{array}$ & Owd & Reat & $\begin{array}{l}\text { Bowh } \\
\text { Tedutes }\end{array}$ & ONt & Rent & \\
\hline Natunt os & 16.7 & 31.6 & 28 & 29.5 & 28 & 266 & 28.4 & 343 & 31.7 & 0.0 & 243 & 243 & 27.0 & 27.4 & 272 \\
\hline Ploctricity & $\mathbf{n s}$ & 00 & ns: & 204 & 34.4 & 31.1 & 22.0 & 375 & 36.1 & 0.0 & 134 & 134 & $2 \$ 9$ & 312 & 29.6 \\
\hline Puel oil & 0.0 & $2 \mathrm{ts}$ & 215 & 22.4 & 28 & ans & 363 & 51.1 & 50.5 & 0.0 & 7.1 & s.1 & 2.4 & 60.9 & 43.7.7 \\
\hline Xercoese & 63 & ses & 62.7 & 0.0 & 46.5 & 163 & 0,0 & 0.0 & 0.0 & 0.0 & 0.0 & 0.0 & 66.3 & 505 & ss 2 \\
\hline Propants & IES & 301 & 235 & 2.7 & 0.0 & 24.7 & 0.0 & 0.0 & 0.0 & 0.0 & 0.0 & 0.0 & 2.6 & 302 & 24.1 \\
\hline Othet Fuck & ns & 0.0 & ins & 0.0 & 0.0 & 00 & 0.0 & $\mathbf{a}, \mathbf{a}$ & 0,0 & ato & 0.0 & 0.0 & 235 & 80 & 205 \\
\hline \multicolumn{16}{|l|}{$\begin{array}{l}\text { No flesting } \\
\text { Jued Uted }\end{array}$} \\
\hline $\begin{array}{l}\text { All } \\
\text { | loustrotats }\end{array}$ & 206 & 33. & 275 & $\mathbf{3 7}$ & 303 & 279 & 205 & 392 & 35.9 & ao & 36.7 & 367 & 25.9 & 34.4 & 30,4 \\
\hline
\end{tabular}




\section{APPENDIX A}

\section{TABLE 0-14}

\section{ALL ELIGIBLE, HIGH-EXPENDITURE, HIGH-BURDEN HOUSEHOLDS BY PROGRAM PARTICIPATION NATTONAL}

\section{THOUSANDS OF HOUSEHOLSS}

\begin{tabular}{|c|c|c|c|c|c|c|c|c|c|c|c|c|c|c|c|}
\hline & \multicolumn{12}{|c|}{ Hoosing Type and Tenure } & & & \multirow[b]{3}{*}{$\begin{array}{l}\text { All } \\
\text { Howoses } \\
\text { Ilootsix }\end{array}$} \\
\hline & \multicolumn{3}{|c|}{ Mobile Howe } & \multicolumn{3}{|c|}{ Strete Pandly } & \multicolumn{3}{|c|}{ Small Multifixmilly } & \multicolumn{3}{|c|}{ Letze Multilumily } & \multicolumn{2}{|c|}{ All Houring Typas } & \\
\hline & On & Renl & $\begin{array}{l}\text { Eoeb } \\
\text { Tcowses }\end{array}$ & Own & Rent & $\begin{array}{l}\text { Botb } \\
\text { Teavecs }\end{array}$ & Omp & Real & $\begin{array}{l}\text { Bowh } \\
\text { Tenurr }\end{array}$ & Ono & Prot & $\begin{array}{l}\text { Boub } \\
\text { Teborse }\end{array}$ & Omn & Real & \\
\hline All thouseboldes & 229 & $\mathbf{t} 13$ & sin & GM1 & 150 & 2,001 & 126 & 223 & 409 & 0 & $\mathbf{s t}$ & $\mathbf{2 t} \mathbf{1}$ & 996 & 1,127 & 2,123 \\
\hline AlDCC Recipients & 65 & 46 & 110 & so & 167 & 218 & o & (5) & 308 & o & $\mathbf{3 2}$ & 32 & 115 & 334 & 469 \\
\hline SSI Roxiptents & $3 \mathbf{H}$ & $2 \%$ & 60 & 84 & 29 & $\$ 13$ & 11 & $\mathbf{3}$ & 34 & 0 & 60 & 60 & $12 x$ & 140 & 266 \\
\hline $\begin{array}{l}\text { Ifealing Aecistance } \\
\text { Reripientr }\end{array}$ & 74 & 60 & 134 & 99 & 120 & 219 & 29 & 3 & 63 & a & 19 & 19 & 202 & 28 & 100 \\
\hline $\begin{array}{l}\text { Pood Stampe } \\
\text { Rosipientis }\end{array}$ & 3 & $\pi$ & 107 & 131 & $20 n$ & $m 7$ & 11 & 129 & 140 & 0 & 100 & 100 & 216 & sog & 725 \\
\hline 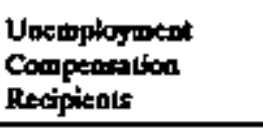 & 0 & 0 & 0 & 0 & $\cdot$ & 0 & $\boldsymbol{x}$ & 0 & 29 & 0 & 27 & 22 & 29 & $n$ & 51 \\
\hline $\begin{array}{l}\text { Subedalyed Ilouring } \\
\text { Rertpienls }\end{array}$ & 0 & 24 & $\mathbf{u}$ & 0 & 42 & $\theta$ & 0 & 20 & 20 & 0 & 0 & 0 & 0 & 86 & 88 \\
\hline
\end{tabular}




\section{APPENDIX A}

TABLE D-15

\section{ALL ELIGIBLE, HIGH-EXPENDITURE, HIGH-BURDEN HOUSEHOLDS BY PROGRAM PARTICIPATION NATIONAL}

\section{PRRCENT OF HOUSEHOLDS}

\begin{tabular}{|c|c|c|c|c|c|c|c|c|c|c|c|c|c|c|c|}
\hline & \multicolumn{12}{|c|}{ Howing Type and Tenure } & & & \multirow[b]{3}{*}{$\begin{array}{l}\text { All } \\
\text { jlonsos } \\
\text { Jlowls }\end{array}$} \\
\hline & \multicolumn{3}{|c|}{ Motile Home } & \multicolumn{3}{|c|}{ Slogte Punily } & \multicolumn{3}{|c|}{ Sinnil Multireminy } & \multicolumn{3}{|c|}{ 1. Multifumily } & \multicolumn{2}{|c|}{ All Jousing Types } & \\
\hline & Own & Rerol & $\begin{array}{l}\text { Botb } \\
\text { Tenures }\end{array}$ & Ows & Real & $\begin{array}{l}\text { Both } \\
\text { Teaures }\end{array}$ & Omn & Rent & $\begin{array}{l}\text { Bouk } \\
\text { Tenures }\end{array}$ & Owd & Real & $\begin{array}{l}\text { Botb } \\
\text { Teaurex }\end{array}$ & Omo & Peat & \\
\hline Av Housecbolds & 9.1 & 9.1 & 182 & 18.2 & $n 3$ & 455 & 9.1 & $9 . t$ & 18.2 & 0.0 & 18: & 182 & 36.4 & 63.6 & 100.0 \\
\hline AFWC Reopientr & 143 & 14.3 & 28,6 & 143 & 20.6 & 429 & 0.0 & 143 & 143 & 0.0 & 143 & 143 & 28.6 & 7.4 & 1000 \\
\hline SST Recipieols & 125 & 125 & 25,0 & 125 & 125 & $\mathbf{2}, 0$ & 125 & 125 & $\mathbf{z . 0}$ & 0.0 & $\mathbf{8 . 0}$ & 80 & 375 & 625 & 100.0 \\
\hline $\begin{array}{l}\text { Itenling Antisunes } \\
\text { Recipicuts }\end{array}$ & 125 & 135 & 25.0 & 125 & $\mathbf{s . 0}$ & 375 & 125 & 125 & 20. & 0.0 & 125 & 125 & 37.5 & 625 & 100.0 \\
\hline $\begin{array}{l}\text { Rood Stumpe } \\
\text { Retiplents }\end{array}$ & 11.1 & 11.1 & $n 2$ & 11.1 & $\cdot \pi 2$ & 33.3 & I1.t & $\mathbf{1 1 . 1}$ & 223 & 0.0 & 222 & $m$ & 393 & 66.7 & 100.0 \\
\hline $\begin{array}{l}\text { Unemploymen } \\
\text { Compentition } \\
\text { Resipientis }\end{array}$ & 0.0 & 00 & 0.0 & 0.0 & p.o & 0.0 & 500 & 0.0 & 50.0 & 0.0 & 50.0 & 500 & $\$ 0.0$ & 50.0 & 100,10 \\
\hline $\begin{array}{l}\text { Subsidted flowing } \\
\text { Retpientit }\end{array}$ & 0.0 & 250 & 25.0 & 0.0 & $\$ 0,0$ & 50.0 & 0.0 & $\mathbf{x}, 0$ & $\mathbf{8 0}$ & 0.0 & 0.0 & $\mathbf{2 0}$ & 0.0 & 100.0 & 1000 \\
\hline
\end{tabular}




\section{APPENDIX A}

\section{TABLE D-16}

\section{ALL ELIGIBLE, HIGH-EXPENDITURE, HIGH-BURDEN HOUSEHOLDS BY PROGRAM PARTICIPATION NATIONAL}

MEAN RESIDENTIAL ENERGX EXPENDITURES IN CURIRENT DOLLARS

\begin{tabular}{|c|c|c|c|c|c|c|c|c|c|c|c|c|c|c|c|}
\hline & \multicolumn{12}{|c|}{ Floniting Type and Tenure } & & & \multirow[b]{3}{*}{$\begin{array}{l}\text { All } \\
\text { Itouns } \\
\text { Ilods }\end{array}$} \\
\hline & \multicolumn{3}{|c|}{ Matilite lifane } & \multicolumn{3}{|c|}{ Sanek Pamily } & \multicolumn{3}{|c|}{ Satll Multifamily } & \multicolumn{3}{|c|}{ Lage Maltifanily } & \multicolumn{2}{|c|}{ All Iloserine Types } & \\
\hline & Owd & Rem & $\begin{array}{l}\text { Hown } \\
\text { Tenoret }\end{array}$ & Owo & $\operatorname{Rens}$ & $\begin{array}{l}\text { Boulb } \\
\text { Tenures }\end{array}$ & Ond & Rent & $\begin{array}{l}\text { Both } \\
\text { Tenurt: }\end{array}$ & Omo & Real & $\begin{array}{l}\text { Boab } \\
\text { Teowes }\end{array}$ & Own & Rend & \\
\hline All Housebolds & 1,180 & 1,360 & 1,253 & 1,465 & $1,+20$ & $t, 446$ & 1,763 & 1,150 & $t, 308$ & $\mathbf{0}$ & 1,004 & 1,004 & 1,450 & 1,240 & 1,399 \\
\hline ArDC Alooipients & 1,194 & 1,515 & 1,300 & 1,507 & 1,503 & t,sol & 0 & 1,191 & 1.t91 & 0 & 57 & 579 & 1,331 & 1,309 & $1, \infty$ \\
\hline SSI Rocipicat: & 1,20 & 1,83 & $1,5+9$ & 1,306 & 1,110 & 1,236 & 553 & 1,256 & 958 & 0 & 1,007 & 1,037 & 1,22 & 1,245 & 1,2015 \\
\hline 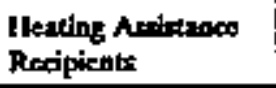 & 1,122 & 1,013 & 1,004 & 1,592 & 1,238 & $1,3 \%$ & 2,497 & 1,248 & $t, 760$ & 0 & 90 & $\operatorname{son}$ & 1,563 & 1,17 & 1,334 \\
\hline $\begin{array}{l}\text { Rood Slampis } \\
\text { Reodpicats }\end{array}$ & $1,12 n$ & 1,443 & 1,2911 & $1, \mathrm{ags}$ & 1,404 & $1,48 \mathrm{~J}$ & 553 & 1,201 & 1,152 & 0 & 1,106 & 1,106 & 1387 & 1,300 & $1,3 \mathrm{~m}$ \\
\hline 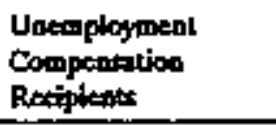 & 0 & 0 & 0 & 0 & . $\quad 0$ & 0 & 2,457 & 0 & 2,437 & 0 & 1,149 & $t, 149$ & 2,437 &, \pm 149 & 1,890 \\
\hline 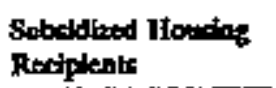 & 0 & 963 & 96 & 0 & 910 & 910 & 0 & 1,068 & 1,058 & 0 & 0 & 0 & 0 & \$9 & 959 \\
\hline
\end{tabular}




\section{APPENDIX A}

TABLE D-17

\section{ALL BLIGIBLE, HIGH-EXPENDITURE, HIGH-BURDEN HOUSEHOLDS BY PROGRAM PARTICIPATION NATTONAL}

\section{MEAN ENERGY BUBRDEN - EXPENDITURES AS \$ OR INCOME}

\begin{tabular}{|c|c|c|c|c|c|c|c|c|c|c|c|c|c|c|c|}
\hline & \multicolumn{12}{|c|}{ Mlonsint Type and Teoure } & & & \multirow[b]{3}{*}{$\begin{array}{l}\text { All } \\
\text { Howex } \\
\text { loolts }\end{array}$} \\
\hline & \multicolumn{3}{|c|}{ Mobile Howe } & \multicolumn{3}{|c|}{ Single Paming } & \multicolumn{3}{|c|}{ Sond Multifnestly } & \multicolumn{3}{|c|}{ Inge Multiamily } & \multicolumn{2}{|c|}{ All Ilowing Tyes } & \\
\hline & $O m$ & Rent & $\begin{array}{l}\text { Bookh } \\
\text { Trenutzs }\end{array}$ & Owa & 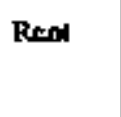 & $\begin{array}{l}\text { Boch } \\
\text { Teaute: }\end{array}$ & Om & Plat & $\begin{array}{l}\text { Both } \\
\text { Teautes }\end{array}$ & Own & Real & $\begin{array}{l}\text { Both } \\
\text { Teutures }\end{array}$ & Own & Rept & \\
\hline Al Hourebolds & 21 & $\boldsymbol{\mu}$ & 28 & 26 & $\mathbf{3 0}$ & $\mathbf{z B}$ & 9 & 3 & 36 & 0 & 37 & 37 & $x$ & 31 & 30 \\
\hline ATtKC Racipients & 40 & $n$ & $\mathbf{u}$ & 18 & 28 & $\mathbf{3}$ & $\mathbf{0}$ & 56 & s6 & 0 & 13 & 13 & 30 & 5 & 34 \\
\hline SST Recipicats & 22 & 25 & 24 & 27 & 16 & 21 & 37 & $\mathbf{z}$ & 29 & 0 & 37 & 37 & 24 & $\boldsymbol{x}$ & 26 \\
\hline 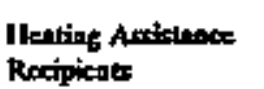 & 36 & 31 & 34 & $x$ & 30 & 31 & 26 & 44 & 36 & 0 & 60 & 60 & 33 & 3 & 34 \\
\hline $\begin{array}{l}\text { Pood Stamps } \\
\text { Rocipieats }\end{array}$ & 36 & 30 & 3 & $\mathbf{2 7}$ & 20 & $\mathbf{2 7}$ & 37 & 51 & 50 & 0 & s: & 51 & 31 & 9 & 36 \\
\hline 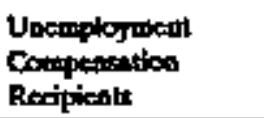 &.$\quad 0$ & 0 & a & 0 & 0 & 0 & $\mathbf{2 x}$ & 0 & $\boldsymbol{x}$ & 0 & 19 & 49 & 26 & 49 & 36 \\
\hline $\begin{array}{l}\text { Subridioed Homing } \\
\text { Recipientr }\end{array}$ & 0 & 28 & 29 & 0 & 21 & 21 & 0 & 49 & 49 & 0 & 0 & 0 & 0 & 29 & 29 \\
\hline
\end{tabular}




\section{APPENDIX A}

TABLE D-18

, ALL ELIGIBLE, HIGH-EXPENDITURE, HIGH-BURDEN HOUSEHOLDS BY DEMOGRAPHIC CHARACTRRISTICS NATTONAL

\section{TBOUSANDS OF HOUSEHOLDS}

\begin{tabular}{|c|c|c|c|c|c|c|c|c|c|c|c|c|c|c|c|}
\hline & \multicolumn{12}{|c|}{ Acosing Type sad Tenare } & & & \multirow[b]{3}{*}{$\begin{array}{l}\text { All } \\
\text { Hlougr } \\
\text { Itodkt }\end{array}$} \\
\hline & \multicolumn{3}{|c|}{ Motike Howne } & \multicolumn{3}{|c|}{ Sngle Pantily } & \multicolumn{3}{|c|}{ Small Multifam } & \multicolumn{3}{|c|}{ Lergo Mulbiamilly } & \multicolumn{2}{|c|}{ All flowsing Types } & \\
\hline & Om & Reat & $\begin{array}{l}\text { Both } \\
\text { Teantrst }\end{array}$ & Omt & Rent & $\begin{array}{l}\text { Beat } \\
\text { Teoost }\end{array}$ & Omb & Reat & $\begin{array}{l}\text { Borb } \\
\text { Teparas }\end{array}$ & Ome & Reat & $\begin{array}{l}\text { Both } \\
\text { Tedutes }\end{array}$ & Omn & Rrnt & \\
\hline All Houserbolits & 209 & 143 & $m$ & 641 & 40 & 1,091 & 126 & 293 & 409 & 0 & $25 \mathbf{1}$ & $\mathbf{2 5 1}$ & 996 & $1,12 \pi$ & 2,120 \\
\hline $\begin{array}{l}\text { IIowsebolts with } \\
\text { Eldenty Mombors }\end{array}$ & 104 & 0 & 104 & 464 & 58 & 527 & 67 & 45 & 112 & 0 & 120 & 120 & 6.5 & 23 & 659 \\
\hline $\begin{array}{l}\text { Hourebollts with } \\
\text { Children }\end{array}$ & $12 x$ & 105 & 229 & 132 & $2 s$ & 407 & 0 & 1to ? & 110 & o & 74 & 74 & 256 & $s G A$ & 8 \\
\hline $\begin{array}{l}\text { Singe-Pareat } \\
\text { jlowsebolds }\end{array}$ & 66 & 13 & 109 & 56 & $1 n$ & 286 & 0 & 123 & 128 & 0 & ss & 55 & 12 & 391 & $\$ 13$ \\
\hline $\begin{array}{l}\text { Artcan-Ametican } \\
\text { Ilousebolds }\end{array}$ & 61 & 60 & 121 & $11 \mathbf{t}$ & 176 & 287 & 58 & $\Leftrightarrow$ & 17 & 0 & 95 & $\$ 5$ & 200 & 400 & 6000 \\
\hline $\begin{array}{l}\text { Htaperaile } \\
\text { tjourcebolss }\end{array}$ & 0 & 0 & 0 & $x$ & $\boldsymbol{n}$ & $1+8$ & 0 & 31 & 31 & 0 & $\boldsymbol{x}$ & $\boldsymbol{n}$ & 76 & $12 x$ & $2 \mathrm{mB}$ \\
\hline $\begin{array}{l}\text { While } \\
\text { Houstolits }\end{array}$ & 168 & BO & 251 & 405 & 232 & $72 t$ & 68 & 188 & 256 & 0 & 15 & 57 & 70 & 660 & 1,391 \\
\hline
\end{tabular}




\section{APPENDIX A}

TABLE D-19

\section{ALL ELIGIBLE, HIGH-EXPENDITURE, HIGH-BURDEN HOUSEHOLDS BY DIMOGRAPHIC CHARACTERISTICS NATIONAL}

\section{PERCENT OF HOUSEHOLDS}

\begin{tabular}{|c|c|c|c|c|c|c|c|c|c|c|c|c|c|c|c|}
\hline & \multicolumn{12}{|c|}{ Hoasling Type and Tenure } & & & \multirow[b]{3}{*}{$\begin{array}{l}\text { All } \\
\text { Iloose } \\
\text { Illoks }\end{array}$} \\
\hline & \multicolumn{3}{|c|}{ Motile liome } & \multicolumn{3}{|c|}{ Single Iamity } & \multicolumn{3}{|c|}{ Smadl Multitamily } & \multicolumn{3}{|c|}{ 1,x/E Multifmaily } & \multicolumn{2}{|c|}{ All Ilousiog 'lypes } & \\
\hline & ONn & Real & $\begin{array}{l}\text { Donb } \\
\text { Thourer }\end{array}$ & $\alpha_{m}$ & RenI & $\begin{array}{l}\text { Bolb } \\
\text { Teadts }\end{array}$ & Ono & Rent & $\begin{array}{l}\text { Bold } \\
\text { Tentres }\end{array}$ & 000 & RenI & $\begin{array}{l}\text { Boib } \\
\text { Tegurss }\end{array}$ & $O_{m n}$ & $R_{\varepsilon a t}$ & \\
\hline Al Itouseboldas & 9.1 & 9.1 & 182 & 182 & 273 & 45 & 9.1 & 9.1 & 18.2 & 0.0 & 182 & 182 & 36.4 & 63.6 & 100.0 \\
\hline $\begin{array}{l}\text { Itouscholds with } \\
\text { Wokrty Member }\end{array}$ & tt.t & 0.0 & 1t.t & 22 & 223 & 4,4 & $11+1$ & $\mathbf{t}+4$ & 202 & 0.0 & 22 & 220 & 44.4 & $\$ 5.6$ & 300.0 \\
\hline $\begin{array}{l}\text { Ilousenolds with } \\
\text { Chtldrea }\end{array}$ & 125 & 125 & $\mathbf{2} 0$ & 125 & ns & so.n & 0.0 & 125 & 125 & 0.0 & 125 & 125 & 25.0 & 2s.o & 100.0 \\
\hline $\begin{array}{l}\text { Sloge-Pareat } \\
\text { Houscholds }\end{array}$ & 125 & 125 & 2500 & 125 & $37 s$ & so.to & 0.0 & 125 & 125 & 0.00 & 125 & 125 & 25.0 & 7.0 & 100.0 \\
\hline 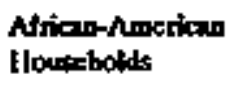 & 11.1 & 11.1 & 222 & 11.1 & 22 & 33 & נ1.J & i1.: & 22 & 0.0 & 23 & 27 & 333 & 66.7 & 100.0 \\
\hline $\begin{array}{l}\text { Itliepanic } \\
\text { Ilossebolots }\end{array}$ & 0.0 & 0.0 & $\mathbf{0 . 0}$ & 333 & 33.3 & 6ht & 0.0 & 16.7 & t6.? & 0.0 & 16.7 & 16.7 & 33.3 & 66.7 & 100.0 \\
\hline $\begin{array}{l}\text { Whathe } \\
\text { Flow bolla: }\end{array}$ & 10.0 & 10.0 & 200 & 20.0 & $\mathbf{3 0 . 0}$ & sao & 100 & t0.0 & 20.0 & 0.0 & 10R & to.t & 40.0 & 40.0 & 1000.0 \\
\hline
\end{tabular}




\section{APPENDIX A}

\section{TABLE D-20}

ALL ELIGIBLE, HIGH-EXPENDIIURE, HIGH-BURDEN HOUSEHOLDS BY DEMOGRAPHIC CHARACTERISTICS NATIONAL

\section{MRAN RESIDENTIAL ENERGY EXPENDITURES IN CURRENT DOUARS}

\begin{tabular}{|c|c|c|c|c|c|c|c|c|c|c|c|c|c|c|c|}
\hline & \multicolumn{12}{|c|}{ Blonsins Type and Thenare } & & & \multirow[b]{3}{*}{$\begin{array}{l}\text { All } \\
\text { flowese } \\
\text { 1lowkt }\end{array}$} \\
\hline & \multicolumn{3}{|c|}{ 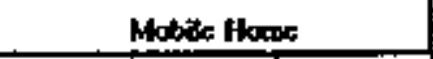 } & \multicolumn{3}{|c|}{ Steofle Panlly } & \multicolumn{3}{|c|}{ Sontt Multlinam } & \multicolumn{3}{|c|}{ 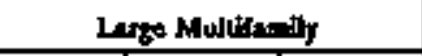 } & \multicolumn{2}{|c|}{ All tlowalas Types } & \\
\hline & Ono & Rent & $\begin{array}{l}\text { Boek } \\
\text { Temore }\end{array}$ & Ont & Reod & $\begin{array}{l}\text { Dolb } \\
\text { Teauns }\end{array}$ & Owo & Rent & $\begin{array}{l}\text { Eloth } \\
\text { Teaurs }\end{array}$ & ONo & Renl & $\begin{array}{l}\text { Doxb } \\
\text { Teoures }\end{array}$ & Own & Real & \\
\hline All Itousebratds & 1,180 & 1,369 & 1,253 & 1,ABS & 1,389 & 1,40 & 1,763 & $t, L_{0}$ & 1,338 & 0 & 1,004 & 1,004 & $t, 4,40$ & 1240 & 1,359 \\
\hline 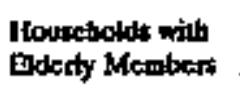 & 60 & 0 & 804 & 1,427 & 997 & 1,380 & 1,506 & 993 & 1,299 & 0 & $\$ 9$ & 90 & $1, \pm 37$ & 992 & $1,2 n$ \\
\hline $\begin{array}{l}\text { Ilowestiolds wh } \\
\text { Childru }\end{array}$ & 1,479 & $t, 3,3$ & $1,41 \mathrm{~s}$ & 1,64 & 1,500 & 1,517 & o & 1,200 & 1,200 & 0 & 1,065 & 3,1055 & 1,563 & 1,255 & $1,1,20$ \\
\hline $\begin{array}{l}\text { Single-Pareat } \\
\text { |lousecholdts }\end{array}$ & 1,763 & 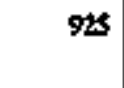 & $t, 432$ & 1,615 & $1, \mathbf{A 1 t}$ & 1,469 & 0 & 1,209 & 1,200 & 0 & 1,106 & 1,206 & $1, \pi 09$ & 1,251 & 1,360 \\
\hline $\begin{array}{l}\text { Arieap-American } \\
\text { llowebolds }\end{array}$ & 1,67 & 4,127 & 1,404 & 1,000 & 1,609 & 1600 & 2,107 & 1,273 & 1,053 & 0 & 930 & 983 & $1,7 \times 0$ & 1,318 & 1,476 \\
\hline 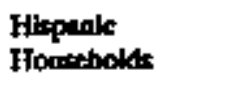 & 0 & 0 & 0 & 1,215 & 1,000 & 1,136 & 0 & 71 & $\overline{711}$ & 0 & 1, $\mathbf{s}$ & $1, B A 1$ & 1,245 & 1,111 & $t, t 61$ \\
\hline $\begin{array}{l}\text { While } \\
\text { Hourceboldk }\end{array}$ & $m$ & 1,54 & 1,17 & 1,490 & 1,106 & 1,37 & $1,4 \pi 2$ & 1,111 & 1,207 & 0 & 1,046 & 1,066 & 1,376 & $1,1,18$ & $t, 260$ \\
\hline
\end{tabular}




\section{APPENDIX A}

TABLE D-21

ALL ELIGIBLE, HIGH-EXPENDITURE, HIGH-BURDEN HOUSEHOLDS BY DEMOGRAPHIC CHARACTERISTICS NATTONAL.

\section{MEAN ENERGY BURDEN - EXPENDITURES AS \$ OF INCOME}

\begin{tabular}{|c|c|c|c|c|c|c|c|c|c|c|c|c|c|c|c|}
\hline & \multicolumn{12}{|c|}{ Hloesing Type and Tenare } & & & \multirow[b]{3}{*}{$\begin{array}{l}\text { Nil } \\
\text { Hiouse } \\
\text { Holda }\end{array}$} \\
\hline & \multicolumn{3}{|c|}{ Nobile Home } & \multicolumn{3}{|c|}{ Stude Pumily } & \multicolumn{3}{|c|}{ Small Multifumity } & \multicolumn{3}{|c|}{ Lage Mvitisumily } & \multicolumn{2}{|c|}{ All Howsing Typer } & \\
\hline & Oms & Rent & $\begin{array}{l}\text { Both } \\
\text { Taluets }\end{array}$ & Ont & Reat & $\begin{array}{l}\text { Both } \\
\text { Terusts }\end{array}$ & Omp & Amal & $\begin{array}{l}\text { Dosb } \\
\text { Tesures }\end{array}$ & Ore & $\mathbf{R}=\mathbf{u}$ & $\begin{array}{l}\text { Both } \\
\text { Teworrs }\end{array}$ & Own & Real & \\
\hline All Housebolds & 24 & 34 & 28 & $\mathbf{x}$ & 30 & 28 & $\mathbf{2 9}$ & 3 & 36 & 0 & 37 & $\mathbf{3 7}$ & 26 & 34 & 30 \\
\hline $\begin{array}{l}\text { Ilouschobots wilb } \\
\text { Diderty Me-mibers }\end{array}$ & 17 & 0 & 17 & 28 & 21 & 28 & 31 & 21 & 27 & 0 & 27 & $n$ & 27 & 25 & $\mathbf{2 0}$ \\
\hline $\begin{array}{l}\text { Itouscbolds wilb } \\
\text { Dhildrea }\end{array}$ & $\Rightarrow$ & 31 & 30 & 21 & 28 & $\mathbf{3 0}$ & 0 & 56 & 56 & 0 & 59 & 59 & $\boldsymbol{z}$ & 3 & 34 \\
\hline 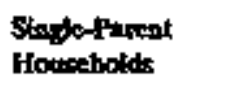 & $\mathbf{3}$ & 41 & 36 & 25 & 35 & $\mathbf{3}$ & 0 & 4 & 4 & 0 & 59 & $\$ 9$ & 29 & 4 & 39 \\
\hline $\begin{array}{l}\text { Africen-Amerlan } \\
\text { Homebolds }\end{array}$ & 16 & 36 & 2 & $\boldsymbol{2}$ & 33 & 31 & 34 & 36 & 35 & 0 & 27 & 27 & 27 & $\mathbf{z}$ & 30 \\
\hline Hippenic & 0 & 0 & 0 & $\mathbf{2}$ & 21 & 2 & 0 & 36 & 36 & 0 & $\boldsymbol{t w}$ & 123 & $\mathbf{2 3}$ & 4 & $n$ \\
\hline $\begin{array}{l}\text { Whito } \\
\text { Ilosesebolds }\end{array}$ & $2 x$ & 32 & z8 & 25 & 33 & 28 & $\boldsymbol{u}$ & 코 & 34 & 0 & 4 & 4 & 25 & 36 & 31 \\
\hline
\end{tabular}




\author{
APPENDIX B \\ ENERGY INFORMATION ADMINISTRATION MAPS \\ U.S. ClIMATE ZONES \\ CENSUS REGIONS \\ CENSUS DIVISIONS
}




\section{APPENDIX C ENERGY INFORMATION ADMINISTRATION MAPS \\ U.S. Climate Zone and Census Regions and Divisions Maps}

\section{U.S. Climate Zone Map}

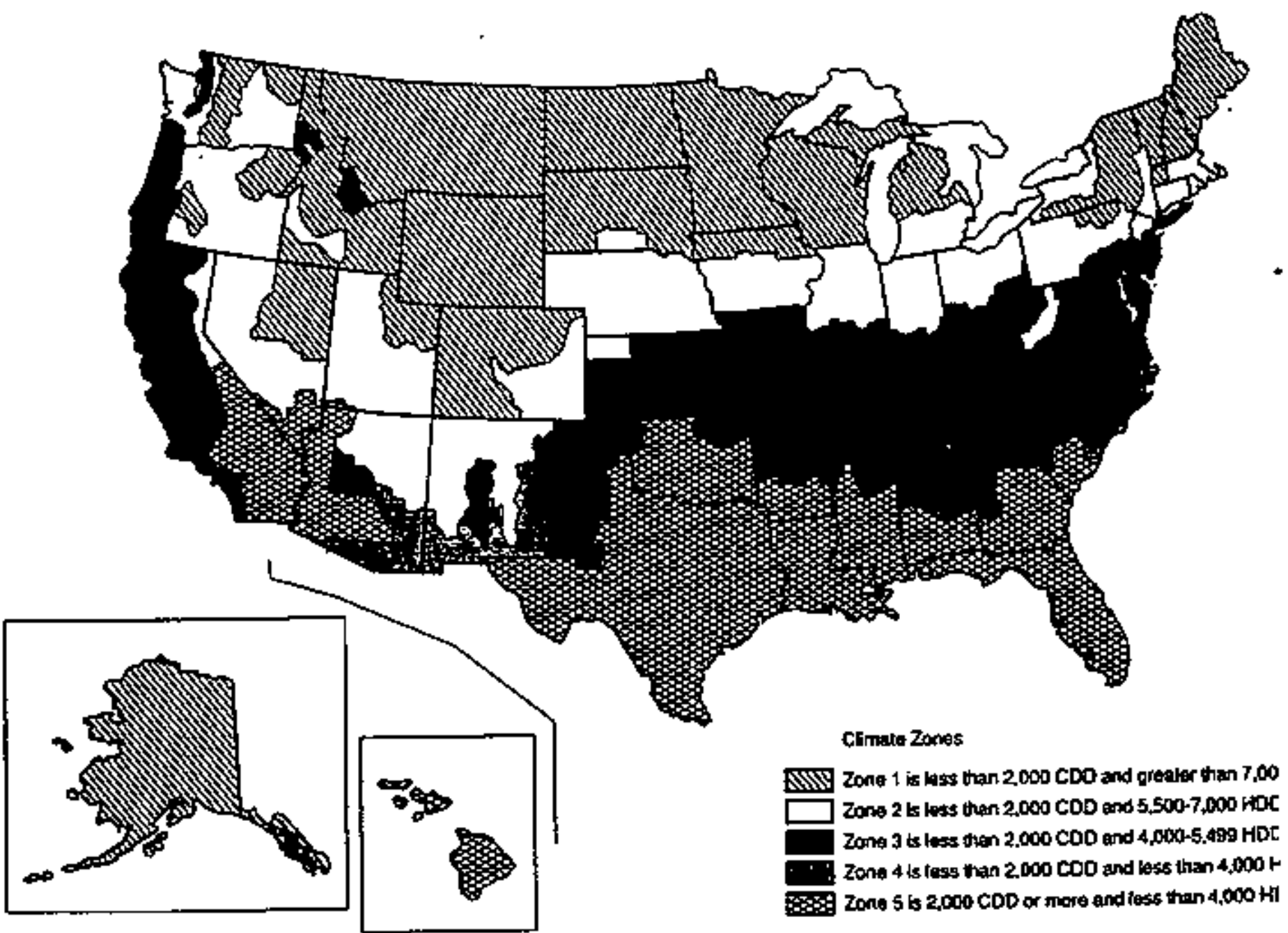




\section{U.S. Census Regions and Divisions}

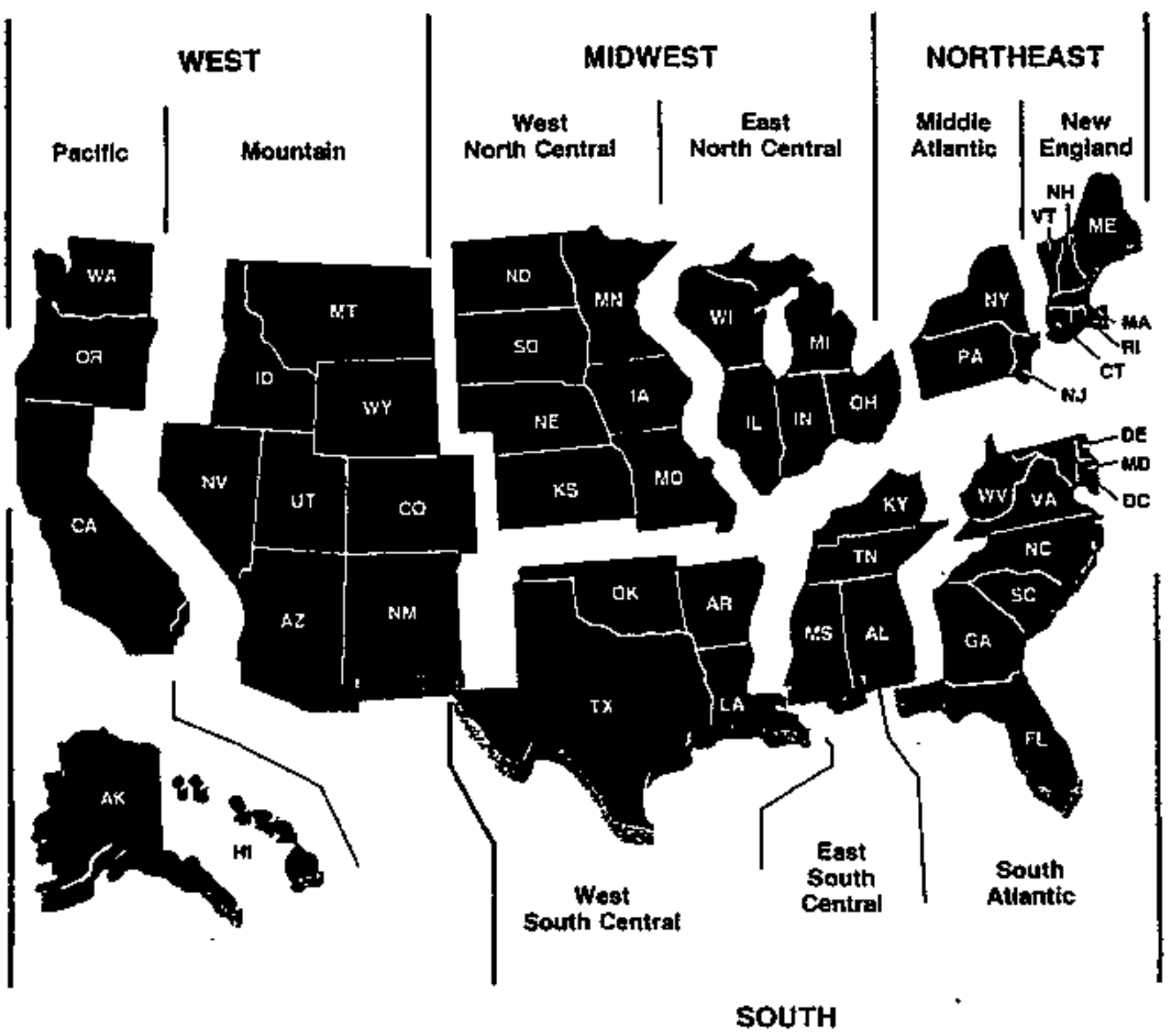

B.5 


\section{INTERNAL DISTTRIBUTION}

I R.A. Balzer, 4500N, MS 6206

2 L.G. Berry, 4500N, MS 6206

3 M.A. Brown, 4500N, MS 6206

4 R.S. Carlsmith, 4500N, MS 6188

5 J.W. Cooke, 4500N, MS 6269

6 T.R. Curlee, $4500 \mathrm{~N}$, MS 6205

7 M.B. Gettings, 3147, MS 6070

8 J.O. Kolb, 3147, MS 6070

9 W.P. Levins, 3147, MS 6070

10 J.M. MacDonald, 3147, MS 6070
II W.R. Mixon, 3147, MS 6070

12 T.R. Sharp, 3147, MS 6070

13-263 4500N, Room H11-D

264 M.P. Tertes, 3147, MS 6070

265 D.L. White, 4500N, MS 6206

266 ORNL Patent Office

267 Central Research Library

268 Document Reference Section

269-71 Laboratory Records (2)

272 Laboratory Records - RC

\section{EXTEANAL DISTRIBUTION}

273 D.A. Bescien, U.S. Department of Energy, 5G-023, EE-70, 1000 Independence Ave., S.W. Washington, DC 20585

274 D.R. Boht, Director, Energy and Natural Resources Division, Resources for the Future, 1616 P Street, N.W., Washagton, DC 20036

275 T.E. Drabek. Professor, Department of Sociology, University of Denver. Denver, Colorado 80208-0209

276 M.A. Fowler, U.S. Depantment of Energy, 5G-023, EE-532. 1000 Independence Avenue, S.W., Wastington, DC 20585

277 C.D. MacCracken, President, Calmac Manufacturing Corporation, I01 West Sheffieló Ave., P.O. Box 7I0. Englewood, NJ 0763 I

278 Office of Assistant Manager for Energy Research and Development, DOE Oak Ridge Fìeld Office, P.O. Box 2008, Oak Ridge, TN 37831+6269

279.280 OSTI, U.S. Department of Energy, P.O. Box 62, Oak Ridge, TN 3783 !

281 J.B. Shrago, Director, Office of Technology Transfer, Vanderbilt University, 405 Kirkland Hall, Nashville. TN 37240

282 G.F. Sowers, P.E., Senior Vice President, Law Companies Group, Inc., 114 Townpark Drive, Suite 250, Kennesaw, Georgia 30144.5599

283 J. Van Vlandren, U.S. Department of Energy, EE-532. 1000 Independence Ave., S.W., Washington, DC 20585

284 C.M. Walton. Paul D. and Betty Robertson Meek Centennial Professor and Chariman, Department of Civil Engineering, Colkege of Engineering, The University of Texas at Atıstin, Cockrell Haft, Suite 4.2, Austin, Texas 78712 